MARLIANE BRITO SAMPAIO

\title{
FISSURAS EM EDIFÍcIOS RESIDENCIAIS EM Alvenaria Estrutural
}

\begin{abstract}
Dissertação apresentada à Escola de Engenharia de São Carlos da Universidade de São Paulo, como parte dos requisitos para obtenção do título de Mestre em Engenharia de Estruturas.
\end{abstract}

Orientador: Prof. Marcio Antonio Ramalho

São Carlos 
AUTORIZO A REPRODUÇÃO E DIVULGAÇÃO TOTAL OU PARCIAL DESTE TRABALHO, POR QUALQUER MEIO CONVENCIONAL OU ELETRÔNICO, PARA FINS DE ESTUDO E PESQUISA, DESDE QUE CITADA A FONTE.

Ficha catalográfica preparada pela Seção de Tratamento da Informação do Serviço de Biblioteca - EESC/USP

Sampaio, Marliane Brito

S192m Fissuras em edifícios residenciais em alvenaria estrutural / Marliane Brito Sampaio ; orientador Marcio Antonio Ramalho. -- São Carlos, 2010.

Dissertação (Mestrado-Programa de Pós-Graduação e Área de Concentração em Engenharia de Estruturas) -- Escola de Engenharia de São Carlos da Universidade de São Paulo, 2010. 
Candidato(a): Bacharel MARLIANE BRITO SAMPAIO.

Dissertação defendida e julgada em 10.12.2010 perante a Comissão Julgadora:

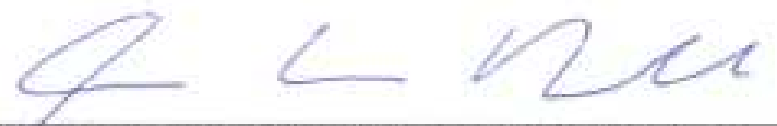

AQ ROUADA

Prof. Associado MARCIO ANTONIO RAMALHO - (Orientador)

(Escola de Engenharia de São Carlos/USP)

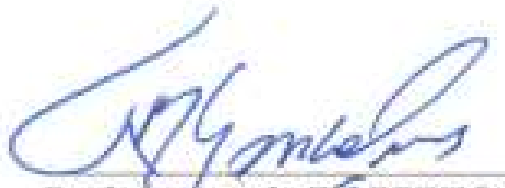

Prof. Associado ROBERTO MARTINS GONÇALVES

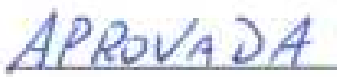

(Escola de Engenharia de São Carlos/USP)

$$
\text { Gydy Instan } h
$$

APROVADA

Prof. Dr. SYDNEY FURL.AN JUNIOR

(Universidade Federal de São Carlos/UFSCar)

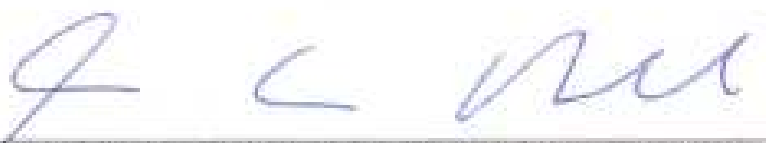

Brof. Associado MARCIO ANTONIO RAMALHO

Coordenador do Programa de Pós-Graduação $\mathrm{cm}$

Engenharia Civil (Engenharia de Estruturas)

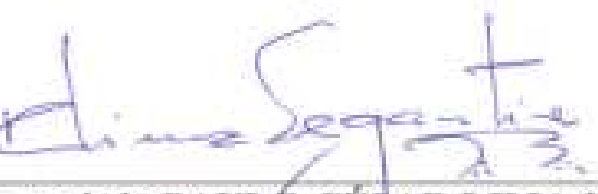

Prof. Associado PAULO CESAR LIMA SEGANTINE

Presidente da Comissào de Pós-Graduaçào 
"O temor do SENHOR é o princípio do conhecimento; os loucos desprezam a sabedoria e a instrução."

Provérbios $1: 7$

"Porque dele e por ele, e para ele, são todas as coisas; glória, pois, a ele eternamente. Amém."

Romanos 11:36

"Mas, buscai primeiro o reino de Deus, e a sua justiça, e as demais coisas vos serão acrescentadas."

Mateus 6:33

"O coração do homem pode fazer planos, mas a resposta certa dos lábios vem do Senhor."

Provérbios 16:1

"O choro pode durar uma noite, mas a alegria vem pela manhã." 


\section{AGRADECIMENTOS}

Ao Senhor Deus com todo o louvor, honra e glória.

Aos meus pais Francisco Sampaio e Luiza Brito pelo apoio e incentivo, além do amor que me deram durante todos os anos (que não são poucos) de minha vida.

Aos meus irmãos, em especial a Márcia "Nanna", que foi uma das que mais me incentivou nessa jornada e que sempre fez parte, com muito carinho, de todos os momentos de minha vida, a Marcilene que mesmo distante buscou do seu jeito está presente me auxiliando, ao Mário "Mano" que mesmo com seu jeito calado sei que está sempre na torcida por mim e tenho muito orgulho disso, a Marlivânia que tenho como meu xodó e mesmo sendo a mais nova muitas vezes foi quem me ajudou a virar gente "grande" e a Érica, minha irmã de coração que é muito especial em minha vida. Amo muito a todos vocês que são meu alicerce e minha fortaleza.

Aos meus sobrinhos que são a razão dos meus sorrisos, em especial João Paulo, Isabela, Gabriela, Victória e Isadora.

Aos meus cunhados Marciano e Adília que conseguiram um lugar especial em meu coração não só pelo amor dedicado a mim, mas principalmente aos meus irmãos e sobrinhos.

Aos meus familiares, em especial a Eliane, Jefferson, Jardeson e Adriana, meus primos sempre presentes em todos os momentos de minha vida, meus tios Edileuza e Agnaldo e minha avó Jovina, pelo carinho.

Aos meus amigos e irmãos da Primeira Igreja Presbiteriana de Roraima, que foram minha fonte de alimento usada por Deus para meu crescimento em Cristo e principalmente na minha caminhada com Ele, em especial ao Pastor Alfredo e ao Pastor Heleno, pessoas que sempre pude contar em meus conflitos diários, mesmo quando distante.

Aos meus amigos da Igreja Presbiteriana de São Carlos, que foram meu suporte durante minha passagem (infelizmente muita rápida) por São Carlos, em especial, Cris \& Marcos, Marga \& Ozéias, Flavinha, Claudinha, Dani, Camillinha, Damiane, Suellen, Alana, Vitinho, Filipe, Marcelo, Lucas, Carol, Uziel, Adans, Wesley, Thiago \& Natália, Gabriel 
Gusmão, Gabriel Amazonas, Angélica, Bel, Rodolfo, Murilo, Eliel, Luciano, Rodrigo, Nelma, Bilzã, Cynthia, Leandro, Thomaz, Valdir, Jader, Juliana, Leon, Ozias, Samuel.

Aos meus amigos de ontem e de sempre Kamyla "Kyka", Marcelo, Osmar e Thiago.

Aos meus amigos de faculdade e companheiros para a vida toda Camila e Thiago.

Aos meus amigos e companheiros de trabalho da Divisão de Arquitetura e Engenharia, do Tribunal de Justiça de Roraima, pelo apoio e incentivo, Fernando, Gláucia e Edivaldo.

Ao professor Marcio Antonio Ramalho, pelo tempo, paciência, incentivo e dedicação disponibilizados na realização desse trabalho.

Aos professores do Departamento de Engenharia de Estruturas pelo vasto conhecimento adquirido durante esses meses de mestrado.

À minha amiga-irmã Gabriela Mazureki “Gabi”, um presente de Deus em minha vida em São Carlos, a quem eu tenho muito respeito, admiração e carinho. Foi meu ombro amigo em tempos bons e ruins que passamos nessa experiência de viver longe da família e é quem eu levarei sempre comigo junto com todas as nossas boas lembranças desse mestrado.

Ao meu amigo André, que mesmo vindo da mesma cidade que eu, somente em São Carlos pude conhecer melhor e admirar tanto quanto o admiro hoje. Dividiu comigo desde o primeiro dia tanto os momentos de angústias como grande parte das minhas alegrias.

Aos meus amigos que tiveram participação de forma direta na realização do meu trabalho, como: Dênis Delázari (meu mano, que com muito carinho conseguiu me aturar todo esse tempo), Jesus Daniel (meu amigo importado, que sofria quando eu resolvia pegar no seu pé...kkk), Erica Kimura, Jésus Sanches, Jonas Dorr e Rodrigo Paccolla.

Aos meus amigos do Departamento de Engenharia de Estruturas, tanto da minha turma como de turmas anteriores, Andreilton \& Aline, André Ramos, Carlos Marek, Danielle Airão, Ellen Kellen, Fernando Soares, Francisco Quim "Chicão”, Hidelbrando Diógenes, Higor Argôlo, Cátia Silva, Raphael Mairal, Rodolfo, Valmiro Quéfren \& Chris Menezes, Wagner Queiroz e Wellison Gomes, Marcela Filizola "Mana”, Dorival, Manoel Denis, Saulo, Bruno e Hugo pelo agradável convívio tanto em momentos de estudo quanto de diversão. 
Aos funcionários do Departamento de Engenharia de Estruturas.

Ao Conselho Nacional de Desenvolvimento Científico e Tecnológico, CNPq e a CAPES, pelo apoio financeiro para a realização desta pesquisa. 


\section{$\underline{\text { RESUMO }}$}

SAMPAIO, M. B. Fissuras em Edifícios Residenciais em Alvenaria Estrutural. 2010.

Dissertação (Mestrado) - Escola de Engenharia de São Carlos, Universidade de São Paulo,

Este trabalho trata de fissura, uma das principais patologias que podem ocorrer em edifícios residenciais em alvenaria estrutural, visando identificar os locais onde elas aparecem com mais frequência, para assim procurar formas de evitá-las. Inicialmente foram realizadas visitas a vários edifícios em alvenaria estrutural de forma a levantar as principais fissuras encontradas nesse tipo de estrutura. Identificou-se que as fissuras são mais frequentes nos contornos de aberturas, diante disse foi realizado um estudo teórico, com a utilização de um programa computacional, para se determinar algumas das principais causas prováveis dessas patologias através de modelos numéricos adequados. Finalmente, foram analisadas algumas das soluções para as patologias encontradas, tentando sugerir as melhores soluções para cada caso.

Palavras-chave: alvenaria estrutural. Fissura. Elemento Finito. 


\section{ABSTRACT}

SAMPAIO, M. B. Fissure in Residential Buildings in Structural Masonry. 2010.

Dissertation (Master degree) - Escola de Engenharia de São Carlos, Universidade de São Paulo, São Carlos, 2010.

This paper deals with fissure, one of major diseases that can occur in a structural masonry residential buildings, in order to identify the locals they usually occur, to seek ways to avoid them. Initially were realized visits a several structural masonry buildings to analise the principals fissures in this type of structure. Was identified that the fissures are more frequently in the contours of openings, given this, was realized a theoretical study using a finite element computer program to identify some of the main possible causes of these pathologies through adequate numerical models. Finally, some possible solutions for the conditions found were analyzed, trying to suggest the best solutions for each case.

Keywords: structural masonry. Fissure. Finite Element. 


\section{SUMÁRIO}

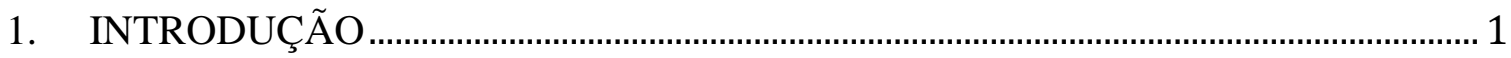

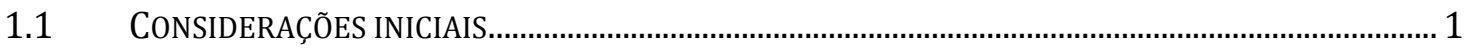

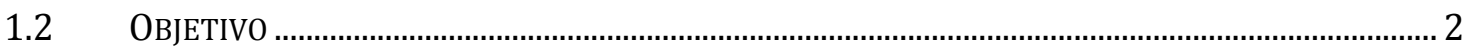

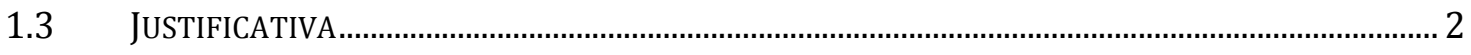

1.4 DESCRIÇÃO DOS CAPÍTULOS .......................................................................................... 3

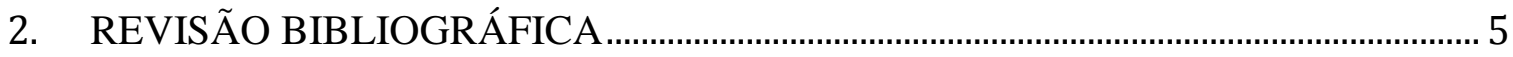

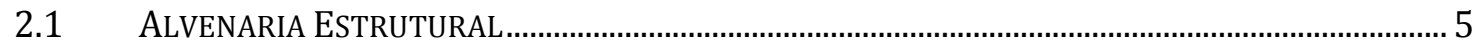

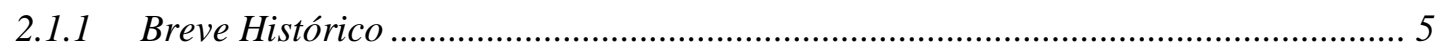

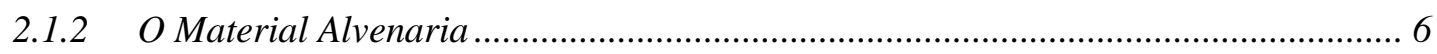

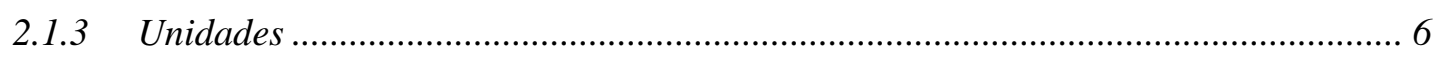

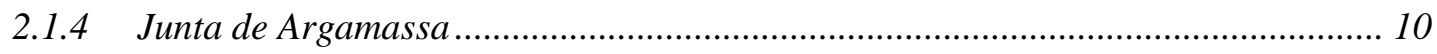

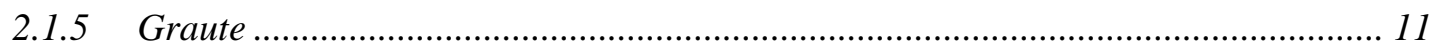

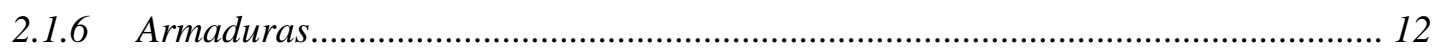

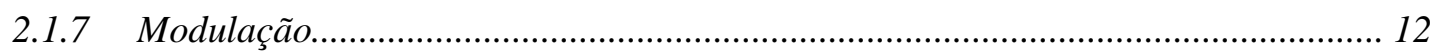

2.1.8 Fatores que afetam a resistência ....................................................................... 14

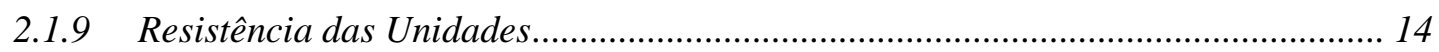

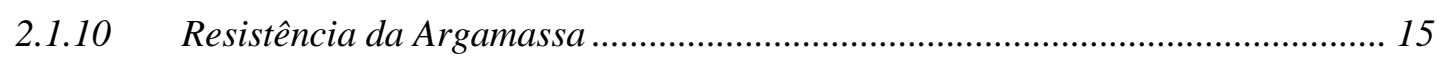

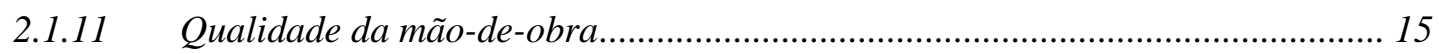

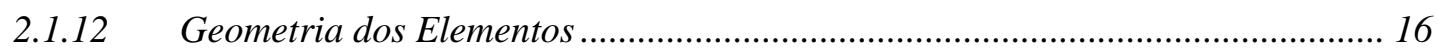

$2.2 \quad$ PATOLOGIAS EM ALVENARIA ESTRUTURAL.......................................................................

2.2.1 Classificação das fissuras quanto às causas.......................................................... 19

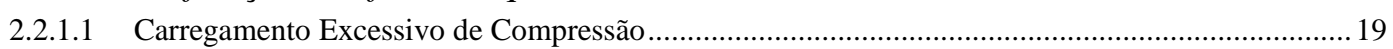

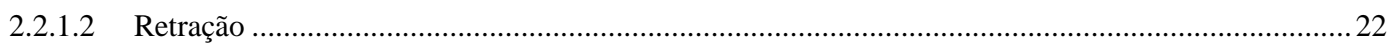

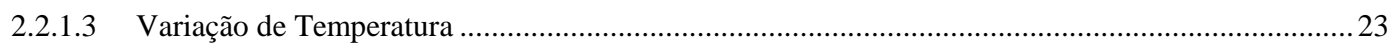

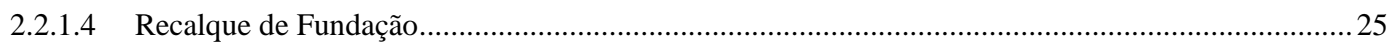

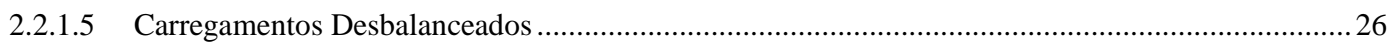

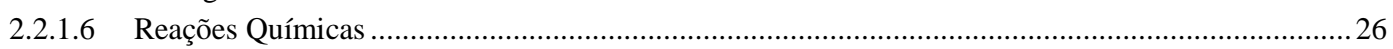

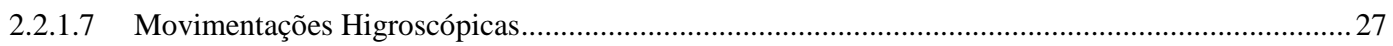

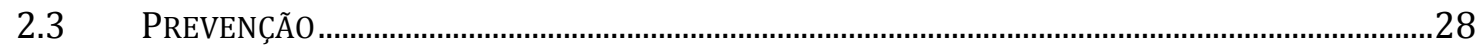

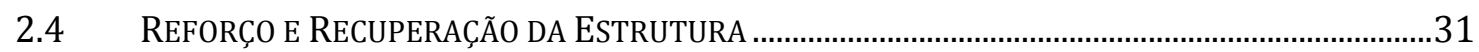

3. FISSURAS OBSERVADAS EM EDIFÍCIOS RESIDENCIAIS .............................................35

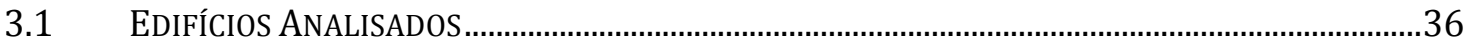

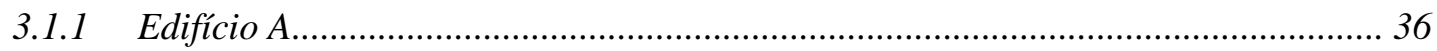

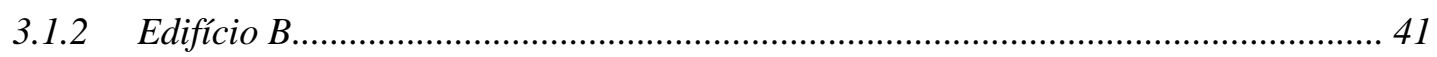

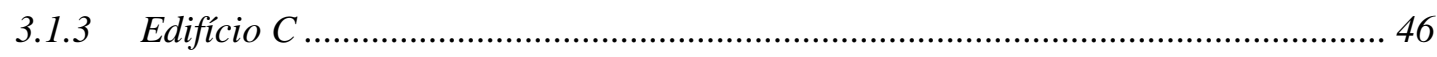

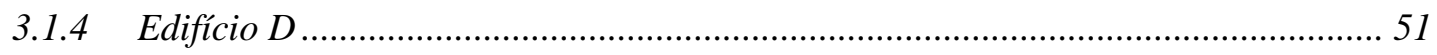

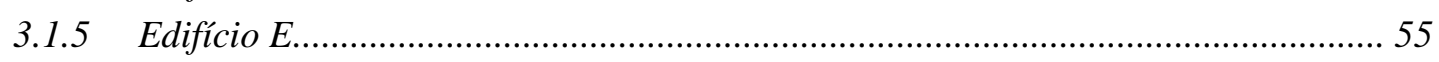

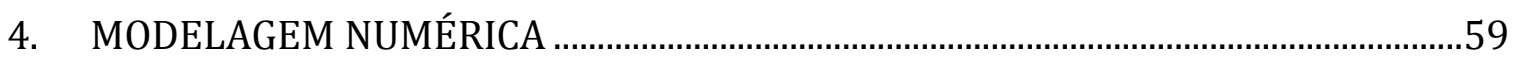

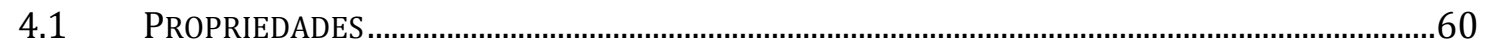




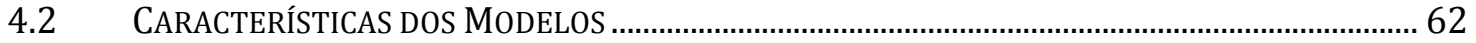

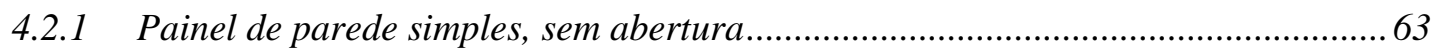

4.2.2 Painéis de paredes com aberturas de portas; .........................................................64

4.2.2.1 Painel de Parede com aberturas de portas, sem reforço..................................................................64

4.2.2.2 Painel de Parede com aberturas de portas com vergas ..........................................................65

4.2.2.3 Painel de Parede com aberturas de portas com vergas e reforços laterais .......................................66

4.2.3 Painéis de paredes com aberturas de janelas ..........................................................6 66

4.2.3.1 Painel de Parede com aberturas de janelas, sem reforço................................................................66

4.2.3.2 Painel de Parede com aberturas de janelas com vergas ...................................................................67

4.2.3.3 Painel de Parede com aberturas de janelas com vergas e contravergas .............................................68

4.2.3.4 Painel de Parede com aberturas de janelas com vergas, contravergas e reforços laterais curtos ......68

4.2.3.5 Painel de Parede com aberturas de janelas com vergas, contravergas e reforços laterais longos .....69

4.2.3.6 Painel de Parede com aberturas de janelas com vergas e cinta à meia altura da parede ....................70

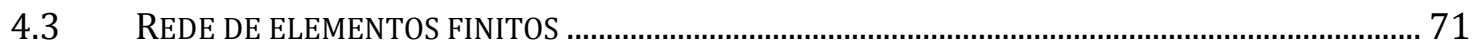

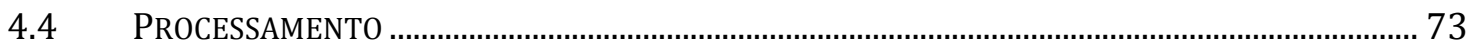

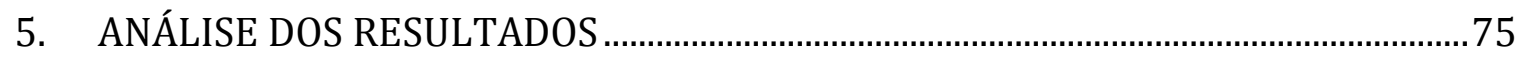

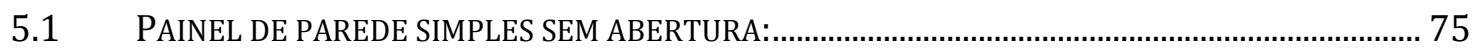

5.2 PAINÉIS DE PAREDES COM ABERTURA DE PORTA....................................................................... 76

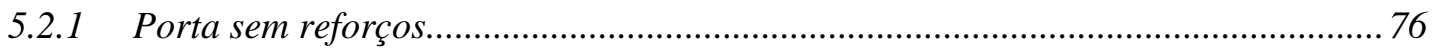

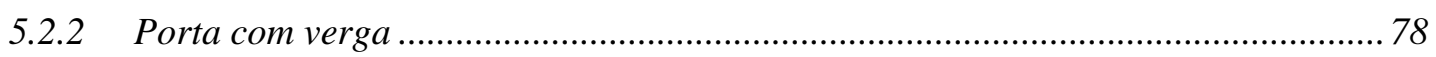

5.2.3 Porta com verga e reforços laterais curtos ........................................................... 80

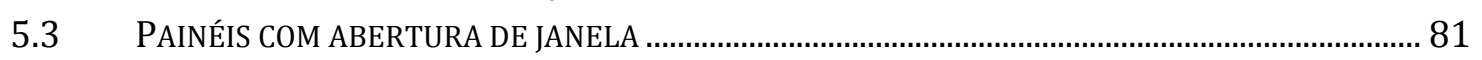

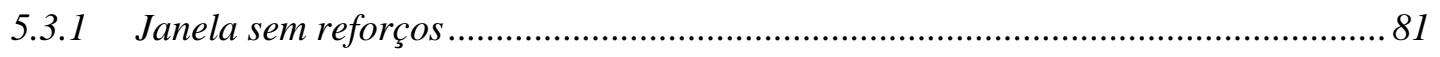

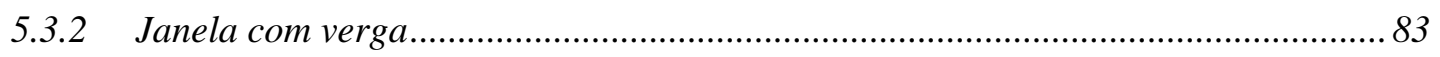

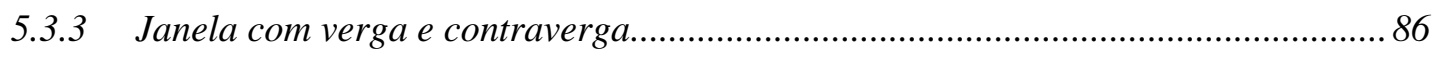

5.3.4 Janela com verga, contraverga e reforços laterais curtos ........................................ 88

5.3.5 Janela com verga, contraverga e reforços laterais longos....................................... 90

5.3.6 Janela com verga e cinta à meia altura da parede................................................ 92

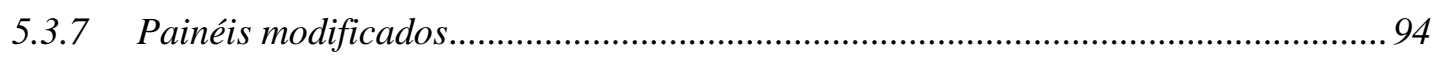

5.3.7.1 Janela com verga de $20 \mathrm{~cm}$ de altura e contraverga com $40 \mathrm{~cm}$ de altura .....................................95

5.3.7.2 Janela com verga de $20 \mathrm{~cm}$ de altura e cinta à meia altura com $40 \mathrm{~cm}$ de altura ...........................95

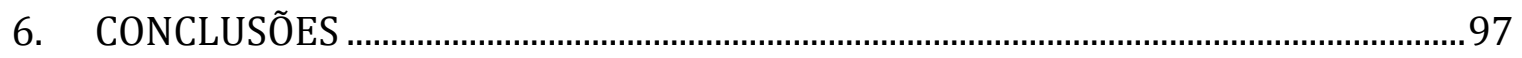

REFERÊNCIAS BIBLIOGRÁFICAS.................................................................................... 103 


\section{LISTA DE FIGURAS}

FigURA 2.1 - CONJUNTO HABITACIONAL CENTRAL PARQUE DA LAPA ............................................. 6

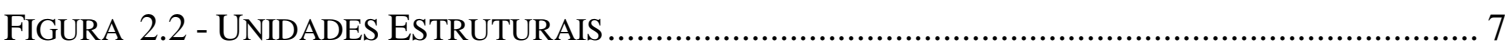

FIGURA 2.3 - TIPOS DE BLOCOS CERÂMICOS. FONTE: CAMACHO/2006 ……................................. 8

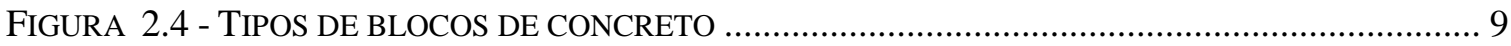

FIGURA 2.5 - ARGAMASSA PARA ASSENTAMENTO DOS BLOCOS ..................................................... 10

FIGURA 2.6 - EXECUÇÃO DE GRAUTEAMENTO. FONTE: ROMAN................................................... 11

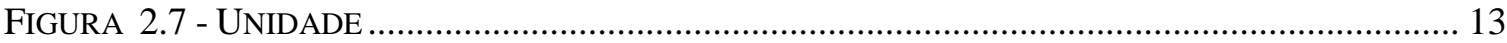

FiguRA 2.8 - DESENHO DOS TIPOS DE AMARRAÇÕES DE BLOCOS. FONTE: CAMACHO/2006 ......... 14

FIGURA 2.9 - CONFIGURAÇÕES BÁSICAS DAS FISSURAS EM ALVENARIA. FONTE: HOLANDA/2002

FIGURA 2.10 - RUPTURA RETILÍNEA E ESCALONADA. FONTE: OLIVEIRA/2001 ….......................... 19

FIGURA 2.11 - FOTO DO CADERNO TÉCNICO DE ALVENARIA ESTRUTURAL. FONTE: BAUER ......... 19

FIGURA 2.12 - ESMAGAMENTO EM PONTOS LOCALIZADOS. FONTE: BAUER …............................. 20

FIGURA 2.13 - FISSURAS EM ALVENARIA PROVENIENTE DE CARGA CONCENTRADA . FONTE:

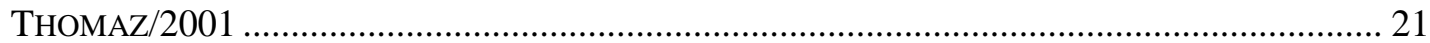

FIGURA 2.14 - FISSURAS CAUSADAS PELA EXCESSIVA DEFORMAÇÃO DA LAJE. FONTE:

OLIVEIRA/2001

FIGURA 2.15 - FISSURAS DEVIDO A CONCENTRAÇÃO DE TENSÕES NO CONTORNO DOS VÃOS.

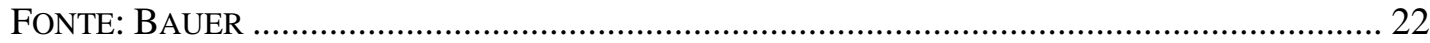

FIGURA 2.16 - FISSURAS CAUSADAS PELA RETRAÇÃO DE LAJES. FONTE: BAUER …….................. 22

FIGURA 2.17 - FISSURAS MAPEADAS . FONTE: THOMAZ/2001 ….................................................. 23

FIGURA 2.18 - FISSURAS DEVIDO À VARIAÇÃO DE TEMPERATURA. FONTE: THOMAZ/2001 .......... 24

FIGURA 2.19 - FISSURAS DEVIDO À EXPANSÃO TÉRMICA DA LAJE DE COBERTURA. FONTE:

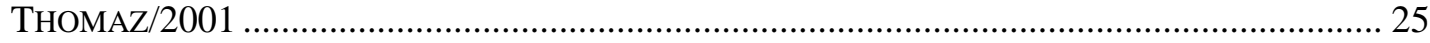

FIGURA 2.20 - FISSURAS DEVIDO À RECALQUE DE FUNDAÇÃO DIFERENCIADO. FONTE:

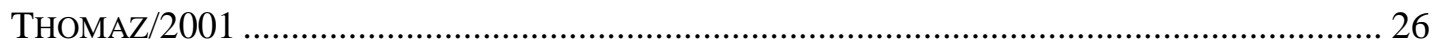

FIGURA 2.22 - FISSURAS DEVIDO À CARREGAMENTOS DESBALANCEADOS. FonTE: THOMAZ/2001

FIGURA 2.23 - FISSURAS PROVOCADAS PELA EXPANSÃO DA ARGAMASSA DE ASSENTAMENTO.

FONTE: THOMAZ/2001

FIGURA 2.24 - FISSURA CAUSADA POR MOVIMENTAÇÕES HIGROSCÓPICAS. FONTE: THOMAZ/2001 
FIGURA 2.25 - APARELHO DE APOIO. FONTE: BASSO

FIGURA 2.26 - JUNTAS DE AMARRAÇÃO COM A UTILIZAÇÃO DE BLOCOS ESPECIAIS. FONTE: CANO/2005 30

FIGURA 2.27 - VERGA E CONTRA-VERGA EM ALVENARIA ESTRUTURAL.

FONTE:WWW.CERAMICAERMIDA.COM.BR 30

FIGURA 3.1 - FACHADAS FRONTAL E LATERAIS DO EDIFÍCIO A 36

FIGURA 3.2 - FISSURA EM CANTO INFERIOR DE ABERTURA DE JANELA EM PAREDE EXTERNA....... 37

FIGURA 3.3 - FISSURA EM CANTO INFERIOR DE ABERTURA DE JANELA EM PAREDE INTERNA........ 37

FIGURA 3.4 - FISSURAS EM CANTOS INFERIORES DE ABERTURAS DE JANELAS. .............................. 38

FIGURA 3.5 - FISSURA VERTICAL NA PARTE INFERIOR DA ABERTURA DE UMA JANELA................... 38

FIGURA 3.6 - FISSURA NO CANTO SUPERIOR DE UMA ABERTURA DE PORTA.....................................39

FIGURA 3.7 - FISSURA NA PARTE INFERIOR DA ABERTURA DE UMA JANELA...................................... 39

FIGURA 3.8 - FISSURA HORIZONTAL NA LATERAL DE VÃO DE PORTA. ............................................ 40

FIGURA 3.9 - FISSURAS NO ENCONTRO DE PAREDES COM LAJES. ................................................. 41

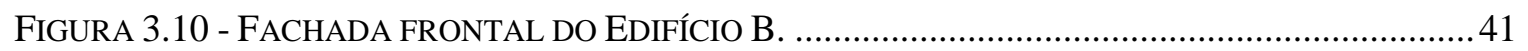

FIGURA 3.11 - FISSURAS HORIZONTAIS NA ALTURA DA LAJE E À MEIA ALTURA DA PAREDE..........42

FIGURA 3.12 - FISSURAS HORIZONTAIS NA ALTURA DA LAJE E À MEIA ALTURA DA PAREDE..........43

FIGURA 3.13 - FISSURAS EM CANTOS DE ABERTURAS DE JANELAS. ............................................... 44

FIGURA 3.14 - FISSURA VERTICAL EM ENCONTRO DE LAJE DE PISO E PAREDE.................................4

FIGURA 3.15 - FISSURA CAUSADA PELO CARREGAMENTO DE UMA LAJE DE SACADA......................45

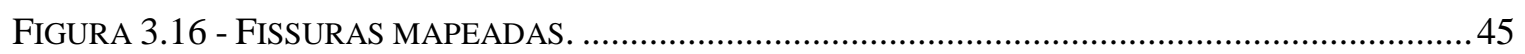

FIGURA 3.17 - FACHADAS FRONTAL E LATERAL DO EDIFÍCIO C ..................................................... 46

FIGURA 3.18 - FISSURAS INTERNAS EM CANTOS INFERIORES DE ABERTURAS DE JANELAS. ...........47

FIGURA 3.19 - FISSURAS EXTERNAS EM CANTOS INFERIORES DE ABERTURAS DE JANELAS. ..........47

FIGURA 3.20 - FISSURA COM FORMATO PREDOMINANTEMENTE HORIZONTAL. ..............................48

FIGURA 3.21 - FISSURA COM FORMATO PREDOMINANTEMENTE VERTICAL. .................................. 48

FIGURA 3.22 - FISSURAS EM CANTOS INFERIORES DE ABERTURAS DE JANELAS. ............................49

FIGURA 3.23 - FISSURA EM CANTO DE ABERTURA DE PORTA........................................................ 49

FIGURA 3.24 - FISSURA EM ENCONTRO DE PAREDES EM ALVENARIA ESTRUTURAL..........................50

FIGURA 3.25 - FISSURA AO LONGO DA BASE DA PAREDE DE ALVENARIA ESTRUTURAL. .................50

FIGURA 3.26 - FACHADA FRONTAL DO EDIFÍCIO D ………............................................................ 51

FIGURA 3.27 - FISSURAS EM CANTOS INFERIORES DE ABERTURAS DE JANELAS. .............................52

FIGURA 3.28 - FISSURAS EM CANTOS INFERIORES DE ABERTURAS DE JANELAS. ............................53 
FIGURA 3.29 - FISSURA NA PARTE INFERIOR DE ABERTURA DE JANELA. ....................................... 54

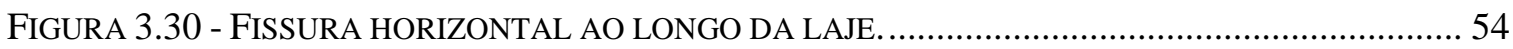

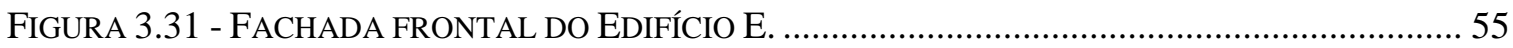

FIGURA 3.32 - FISSURAS EM CANTO DE ABERTURA DE JANELA...................................................... 56

FIGURA 3.33 - FISSURAS HORIZONTAIS NA PARTE LATERAL DO VÃO........................................... 56

FIGURA 3.34 - FISSURAS NOS CANTOS SUPERIORES DE ABERTURAS DE JANELAS. ........................ 57

FIGURA 3.35 - FISSURAS CAUSADAS PELO CARREGAMENTO DAS LAJES......................................... 58

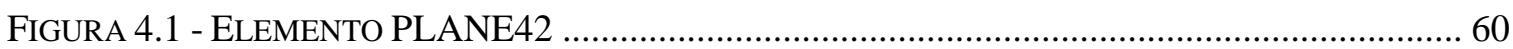

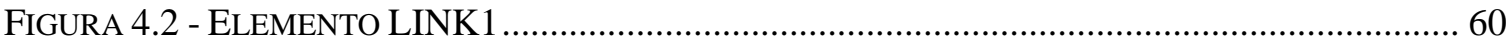

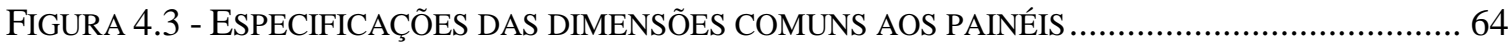

FIGURA 4.4 - PAINEL DE PAREDE COM ABERTURAS DE PORTAS SEM REFORÇO ............................... 65

FIGURA 4.5 - PAINEL DE PAREDE COM ABERTURAS DE PORTAS COM VERGAS ................................ 65

FIGURA 4.6 - PAINEL DE PAREDE COM ABERTURAS DE PORTAS COM VERGAS E REFORÇOS LATERAIS 66

FIGURA 4.7 - PAINEL DE PAREDE COM ABERTURAS DE JANELAS SEM REFORÇO. 67

FIGURA 4.8 - PAINEL DE PAREDE COM ABERTURAS DE JANELAS COM VERGAS. 67

FigURA 4.9 - PAINEL DE PAREDE COM ABERTURAS DE JANELAS COM VERGAS E CONTRAVERGAS68

FigURA 4.10 - PAINEL DE PAREDE COM ABERTURAS DE JANELAS COM VERGAS, CONTRAVERGAS E REFORÇOS LATERAIS CURTOS.

FIGURA 4.11 - PAINEL DE PAREDE COM ABERTURAS DE JANELAS COM VERGAS, CONTRAVERGAS E REFORÇO LATERAL LONGO

FIGURA 4.12 - PAINEL DE PAREDE COM ABERTURAS DE JANELAS COM VERGAS E CINTA À MEIA ALTURA DA PAREDE 70

FIGURA 4.13 - REDE DO MODELO DE PAREDE SEM ABERTURAS. 71

FIGURA 4.14 - REDE REFERENTE AOS MODELOS DE PAREDE COM ABERTURAS DE PORTAS. ......... 72

FIGURA 4.15 - REDE REFERENTE AOS MODELOS DE PAREDES COM ABERTURAS DE JANELAS....... 72

FIGURA 5.1 - TENSÕES PRINCIPAIS I EM PAINEL DE PAREDE SIMPLES SEM ABERTURAS, COM VALORES ENTRE 0 E 0.30MPA.

FIGURA 5.2 - TENSÕES PRINCIPAIS I EM PAINEL DE PAREDE COM ABERTURA DE PORTA SEM REFORÇO, COM VALORES ENTRE 0 E 0.30MPA

FIGURA 5.3 - TENSÕES PRINCIPAIS I EM PAINEL DE PAREDE COM ABERTURA DE PORTA SEM REFORÇO, COM VALORES ENTRE 0 E 0.18MPA.

FIGURA 5.4 - TENSÕES PRINCIPAIS I EM PAINEL DE PAREDE COM ABERTURA DE PORTA COM VERGA, COM VALORES ENTRE 0 E 0.30MPA. 
FIGURA 5.5 - TENSÕES PRINCIPAIS I EM PAINEL DE PAREDE COM ABERTURA DE PORTA COM VERGA, COM VALORES ENTRE 0 E 0.18MPA.

FIGURA 5.6 - TENSÕES PRINCIPAIS I EM PAINEL DE PAREDE COM ABERTURA DE PORTA COM VERGA, E REFORÇOS LATERAIS, COM VALORES ENTRE 0 E 0.30MPA.

FIGURA 5.7 - TENSÕES PRINCIPAIS I EM PAINEL DE PAREDE COM ABERTURA DE PORTA COM VERGA, E REFORÇOS LATERAIS, COM VALORES ENTRE 0 E 0.18MPA.

FIGURA 5.8 - TENSÕES PRINCIPAIS I EM PAINEL DE PAREDE COM ABERTURA DE JANELA SEM REFORÇO, COM VALORES ENTRE 0 E 0.60MPA.

FIGURA 5.9 - TENSÕES PRINCIPAIS I EM PAINEL DE PAREDE COM ABERTURA DE JANELA SEM REFORÇO, COM VALORES ENTRE 0 E 0.40MPA

FIGURA 5.10 - TENSÕES PRINCIPAIS I EM PAINEL DE PAREDE COM ABERTURA DE JANELA SEM REFORÇO, COM VALORES ENTRE 0 E $0.25 \mathrm{MPA}$.

FIGURA 5.11 - TENSÕES PRINCIPAIS I EM PAINEL DE PAREDE COM ABERTURA DE JANELA COM VERGA, COM VALORES ENTRE 0 E 0.60MPA.

FIGURA 5.12 - TENSÕES PRINCIPAIS I EM PAINEL DE PAREDE COM ABERTURA DE JANELA COM VERGA, COM VALORES ENTRE 0 E 0.60MPA.

FIGURA 5.13 - TENSÕES PRINCIPAIS I EM PAINEL DE PAREDE COM ABERTURA DE JANELA COM VERGA, COM VALORES ENTRE 0 E 0.60MPA.

FIGURA 5.14 - TENSÕES PRINCIPAIS I EM PAINEL DE PAREDE COM ABERTURA DE JANELA COM VERGA E CONTRAVERGA, COM VALORES ENTRE 0 E 0.60MPA.

FIGURA 5.15 - TENSÕES PRINCIPAIS I EM PAINEL DE PAREDE COM ABERTURA DE JANELA COM VERGA E CONTRAVERGA, COM VALORES ENTRE 0 E 0.40MPA.

FIGURA 5.16 - TENSÕES PRINCIPAIS I EM PAINEL DE PAREDE COM ABERTURA DE JANELA COM VERGA E CONTRAVERGA, COM VALORES ENTRE 0 E 0.25 MPA..

FIGURA 5.17 - TENSÕES PRINCIPAIS I EM PAINEL DE PAREDE COM ABERTURA DE JANELA COM VERGA, CONTRAVERGA E REFORÇOS LATERAIS CURTOS, COM VALORES ENTRE 0 E 0.60MPA.

FIGURA 5.18 - TENSÕES PRINCIPAIS I EM PAINEL DE PAREDE COM ABERTURA DE JANELA COM VERGA, CONTRAVERGA E REFORÇOS LATERAIS CURTOS, COM VALORES ENTRE 0 E 0.40MPA.

FIGURA 5.19 - TENSÕES PRINCIPAIS I EM PAINEL DE PAREDE COM ABERTURA DE JANELA COM VERGA, CONTRAVERGA E REFORÇOS LATERAIS CURTOS, COM VALORES ENTRE 0 E 0.25MPA.

FIGURA 5.20 - TENSÕES PRINCIPAIS I EM PAINEL DE PAREDE COM ABERTURA DE JANELA COM VERGA, CONTRAVERGA E REFORÇOS LATERAIS LONGOS, COM VALORES ENTRE 0 E 0.60MPA.

FIGURA 5.21 - TENSÕES PRINCIPAIS I EM PAINEL DE PAREDE COM ABERTURA DE JANELA COM VERGA, CONTRAVERGA E REFORÇOS LATERAIS LONGOS, COM VALORES ENTRE 0 E 0.40MPA. 
FIGURA 5.22 - TENSÕES PRINCIPAIS I EM PAINEL DE PAREDE COM ABERTURA DE JANELA COM VERGA, CONTRAVERGA E REFORÇOS LATERAIS LONGOS, COM VALORES ENTRE 0 E $0.25 \mathrm{MPA}$.

FIGURA 5.23 - TENSÕES PRINCIPAIS I EM PAINEL DE PAREDE COM ABERTURA DE JANELA COM VERGA, CINTA À MEIA ALTURA DA PAREDE, COM VALORES ENTRE 0 E 0.60MPA. 93

FIGURA 5.24 - TENSÕES PRINCIPAIS I EM PAINEL DE PAREDE COM ABERTURA DE JANELA COM VERGA, CINTA À MEIA ALTURA DA PAREDE, COM VALORES ENTRE 0 E 0.40MPA.

FIGURA 5.25 - TENSÕES PRINCIPAIS I EM PAINEL DE PAREDE COM ABERTURA DE JANELA COM VERGA, CINTA À MEIA ALTURA DA PAREDE, COM VALORES ENTRE 0 E 0.25MPA. 94

FIGURA 5.26 - TENSÕES PRINCIPAIS I EM PAINEL DE PAREDE COM ABERTURA DE JANELA COM VERGA DE 20CM DE ALTURA E CONTRAVERGA COM 40 CM DE ALTURA, COM VALORES ENTRE 0 E $0.20 \mathrm{MPA}$

FIGURA 5.27 - TENSÕES PRINCIPAIS I EM PAINEL DE PAREDE COM ABERTURA DE JANELA COM VERGA DE 20CM DE ALTURA E CINTA À MEIA ALTURA COM 40 CM DE ALTURA,COM VALORES ENTRE 0 E $0.25 \mathrm{MPA}$ 



\section{LISTA DE TABELAS}

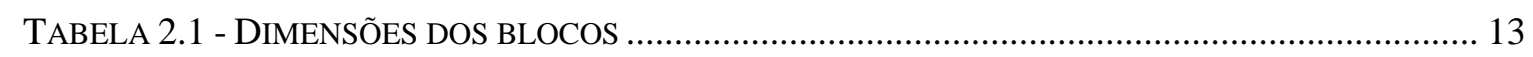

TABELA 4.1 - PARÂMETROS UTILIZADOS NOS MATERIAIS DOS MODELOS ......................................... 61 


\section{INTRODUÇÃO}

\subsection{CONSIDERAÇÕES INICIAIS}

A alvenaria estrutural é um processo construtivo no qual os elementos que desempenham a função estrutural são a própria alvenaria, dispensando o uso de pilares e vigas, o que acarreta redução de custos.

Esse sistema estrutural vem evoluindo com o passar dos anos e com isso tem-se conseguido estruturas mais seguras e econômicas, um canteiro de obra mais organizado e limpo, além de um menor tempo de execução.

O emprego da alvenaria estrutural, seja de bloco de concreto ou cerâmico, proporciona algumas facilidades construtivas, tais como:

× Técnicas de execução simplificadas;

× Menor diversidade de materiais empregados;

× Redução do número de especializações de mão-de-obra empregada;

× Redução de interferências, entre os subsistemas, no cronograma executivo (estrutura e alvenaria são executadas conjuntamente).

Sua principal desvantagem é a impossibilidade de adaptações nos arranjos arquitetônicos, a menos que já tenham sido previstas em projeto.

A alvenaria estrutural, por sua grande semelhança com a alvenaria convencional, sofre basicamente os mesmos tipos de anomalias, que são em sua maioria fissuras.

Segundo Holanda/2002, as fissuras são patologias comuns em alvenaria estrutural, pois os materiais utilizados na fabricação das unidades, tais como cerâmica, concreto e demais matérias-primas, assim como da argamassa utilizada são frágeis e apresentam baixa resistência á tração. Como a alvenaria é composta por unidades e argamassas, ela também apresenta essas características.

Ainda segundo Holanda/2002, a resistência à tração nas interfaces entre as unidades e a argamassa é muito pequena, o que faz com que essas superfícies se tornem susceptíveis á separação. 
Essas anomalias ocorrem não apenas pelas características físicas do material que constitui a estrutura, mas também devido a deficiências de projeto, especificação de material, execução e utilização do edifício.

A identificação das fissuras, através da sua configuração, abertura, espaçamento e época de ocorrência, ajudam a diagnosticar sua origem, que é um fator muito importante para a definição da alternativa adequada para a recuperação da alvenaria.

\subsection{OBJETIVO}

O presente trabalho tem por objetivo analisar fissuras encontradas em edifícios residenciais em alvenaria estrutural, identificar os tipos mais frequentes nos edifícios analisados, a fim de descobrir suas causas prováveis e possíveis soluções.

\subsection{JUSTIFICATIVA}

O interesse pelo sistema construtivo alvenaria estrutural vem aumentando de forma notável principalmente pelos resultados que se obtém relacionados à economia.

Entretanto, por ser um sistema considerado recente no país, há a necessidade do avanço nas pesquisas que auxiliem no desenvolvimento de seus aspectos tecnológicos. Dessa forma, se poderá aumentar o conhecimento do comportamento desse tipo de estrutura, inclusive para subsidiar a obtenção de uma boa normalização visando projetos seguros e econômicos, voltados à realidade do Brasil.

A ocorrência de fissuras em edifícios residenciais em alvenaria estrutural é um dos problemas que ainda necessitam de muita atenção e estudo. Por esse motivo, este trabalho pretende analisar as suas principais causas e soluções e encontrar formas de amenizar esse problema, ajudando assim no crescimento e aceitação desse tipo de estrutura pelo mercado. 


\subsection{DESCRIÇÃO dOS CAPÍTUlOS}

No capítulo 02 apresenta-se uma revisão sobre a alvenaria estrutural, desde o panorama histórico até os tipos de manifestações patológicas encontradas nesse tipo de estrutura, assim como suas formas de prevenção, recuperação e reforço.

No capítulo 03 é apresentado o trabalho de campo, com a documentação fotográfica e a descrição das fissuras encontradas nos edifícios analisados.

No capítulo 04 faz-se um estudo teórico do problema das fissuras junto às aberturas com a utilização do programa computacional ANSYS ${ }^{\circledR}$ V10.0.

No capítulo 05 tem-se a análise dos resultados encontrados no estudo feito no capítulo 04, em comparação com os resultados obtidos no trabalho de campo apresentado no capítulo 03.

No capítulo 06 apresentam-se as conclusões do trabalho. 


\section{REVISÃO BIBLIOGRÁFICA}

\subsection{ALVENARIA ESTRUTURAL}

\subsubsection{BREVE HisTóRICO}

A alvenaria é utilizada desde a Antiguidade, sendo que dessa época até o início do século XX foram executadas de forma empírica, o que resultava em estruturas mais robustas quando comparadas com as utilizadas hoje em dia.

Com o passar do tempo, novas tecnologias construtivas e até mesmo novos materiais passaram a ser utilizados para se executar estruturas. Mesmo a alvenaria, que já existia, foi aperfeiçoada através da criação de procedimentos de execução e técnicas de dimensionamento específicas, evoluindo até chegar à alvenaria estrutural como é conhecida hoje.

Em 1950, Paul Haller dimensionou e construiu na Suíça um edifício com 13 pavimentos e $42 \mathrm{~m}$ de altura, em alvenaria não armada. As paredes internas possuíam 15 $\mathrm{cm}$ de espessura e as externas $37,5 \mathrm{~cm}$.

O avanço da alvenaria estrutural possibilitou sua utilização até mesmo em zonas sujeitas a abalos sísmicos, onde para esses casos existe a exigência de utilização de alvenaria armada. Diante disso, muitos edifícios em alvenaria estrutural passaram a ser construídos na Inglaterra, Alemanha, Suíça e Estados Unidos.

No Brasil os primeiros edifícios foram construídos em 1966, no Condomínio Central Parque Lapa em São Paulo, com apenas quatro pavimentos executados com blocos de concreto.

Em 1972, no mesmo condomínio, foram executados quatro blocos de 12 pavimentos com tecnologia importada dos Estados Unidos, a qual utilizava blocos de concreto e bastante armadura devido aos efeitos sísmicos. 


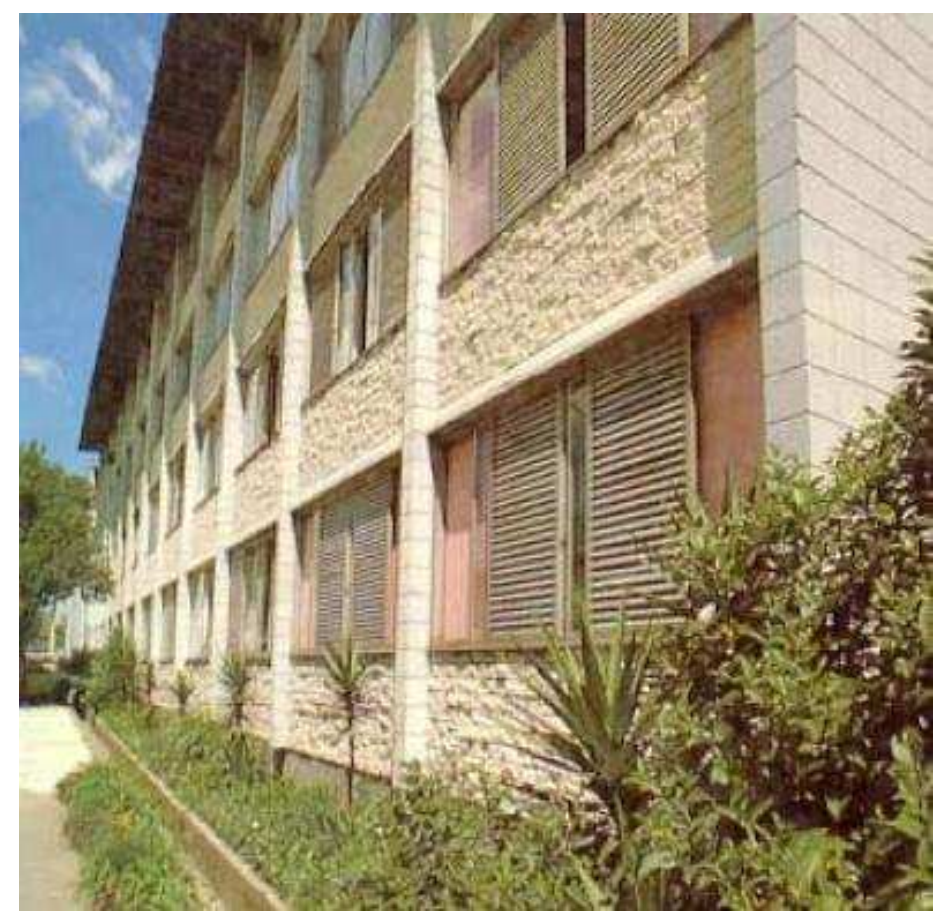

Figura 2.1 - Conjunto Habitacional Central Parque da Lapa

FONTE: Darini/2006

\subsubsection{O MATERial Alvenaria}

A alvenaria estrutural é um material composto por unidades (blocos ou tijolos), argamassa e, eventualmente, graute e armadura (construtiva ou de cálculo), sendo esses dois últimos utilizados para o reforço da estrutura.

A combinação de dois ou mais desses componentes formam os elementos, como paredes, pilares, cintas e vergas.

É comum também a presença de elementos pré-fabricados, como coxins, vergas, contravergas e outros acessórios.

\subsubsection{UNIDADES}

As unidades são os principais componentes da alvenaria estrutural, sendo em grande parte responsáveis pela característica resistente do material alvenaria. Além disso, as unidades são a base da coordenação modular nos projetos de estruturas em alvenaria estrutural. 
Conforme o material utilizado na sua fabricação, elas são denominadas como: unidades de concreto, unidades cerâmicas, unidades silico-calcáreas.

De acordo com a porcentagem de vazios, elas são classificadas como unidades maciças, quando possui até $25 \%$ da área total formada por vazios, ou unidades vazadas, quando essa área é superior a $25 \%$.

No Brasil as unidades de concreto são as mais utilizadas, seguidas pelas cerâmicas.

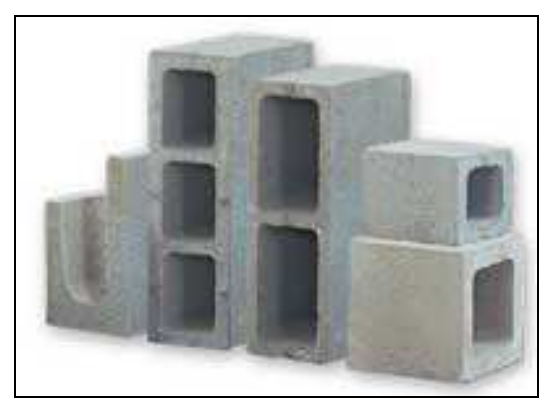

Unidade de Concreto

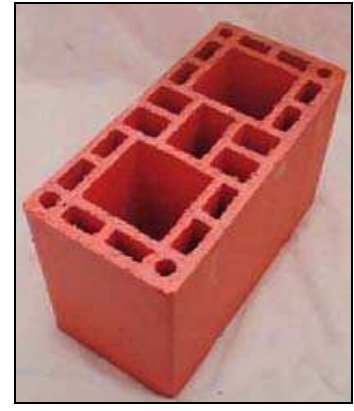

Unidade Cerâmica

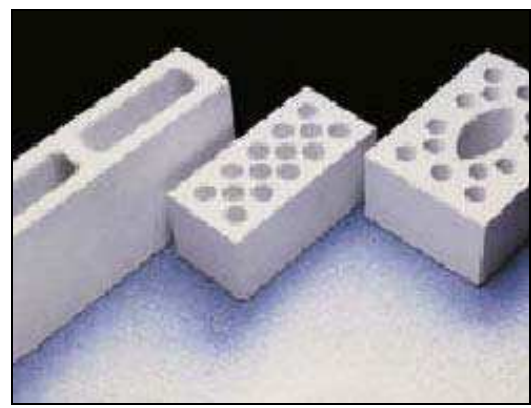

Unidade Sílico-calcárea

Figura 2.2 - Unidades Estruturais

Fonte: Freitas/2008

Essas unidades podem ser produzidas com diferentes formas, cores, texturas e resistências, conforme a necessidade de cada edificação.

Os vazios das unidades podem ser utilizados para a passagem de tubulação elétrica e para a execução de cintas de amarração e vergas. Além disso, podem ser utilizados juntamente com o preenchimento com graute para a fixação da armadura na estrutura ou para aumentar a resistência à compressão da alvenaria.

As principais propriedades que as unidades devem possuir são:

× Resistência à compressão

× Estabilidade dimensional

× Vedação

× Absorção adequada

× Trabalhabilidade 
× Modulação

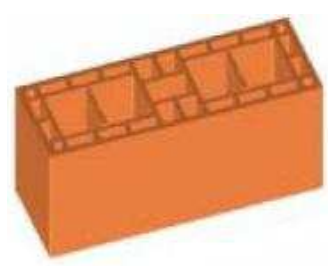

Bloco Inteiro
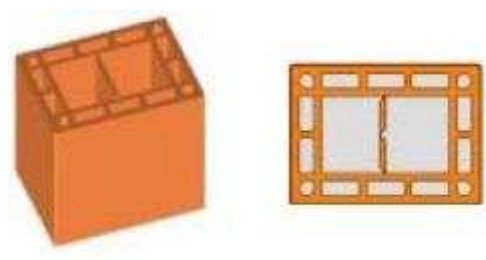

Meio Bloco

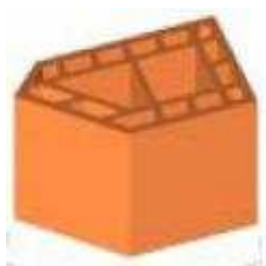

Bloco de Canto

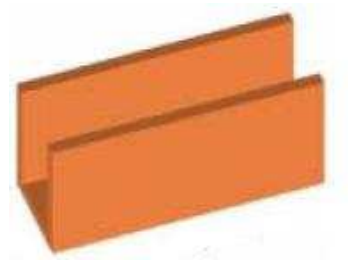

Bloco Canaleta
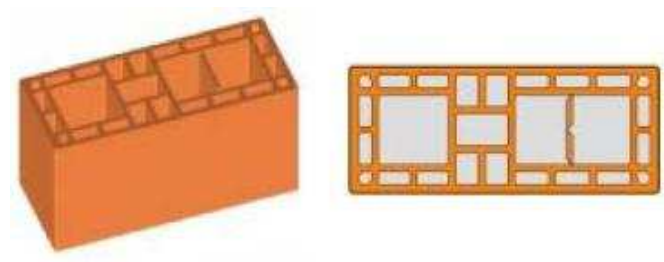
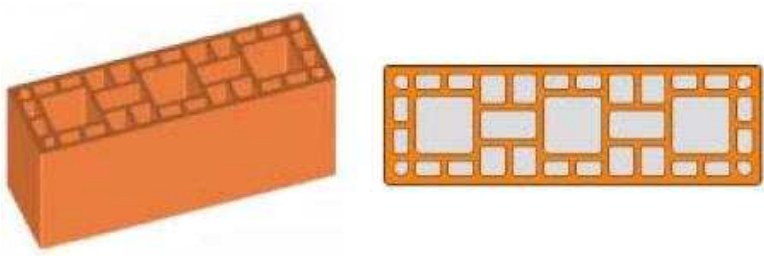

Bloco Especial 14x44
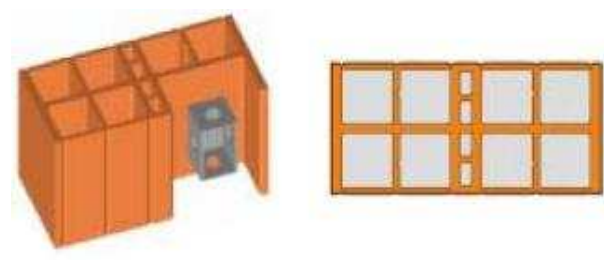

Bloco Elétrico
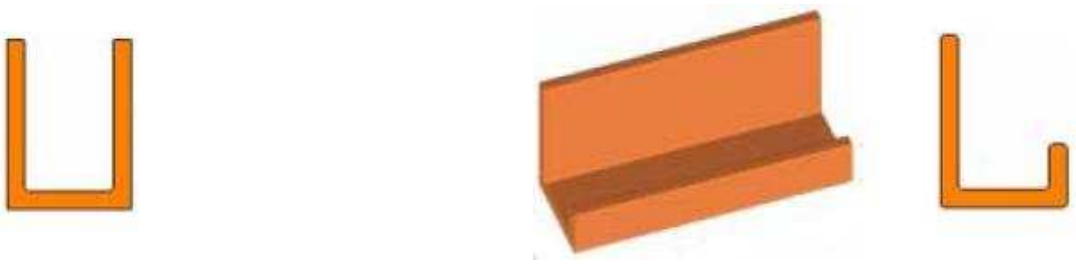

Bloco Jota
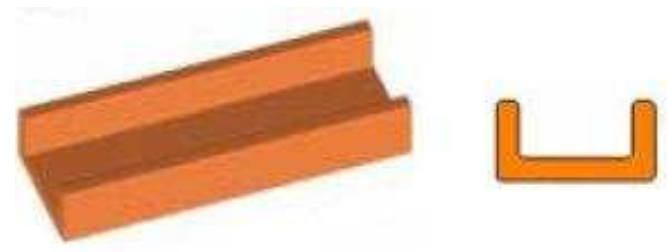

Bloco Compensador

Figura 2.3 - Tipos de blocos cerâmicos. Fonte: Camacho/2006 


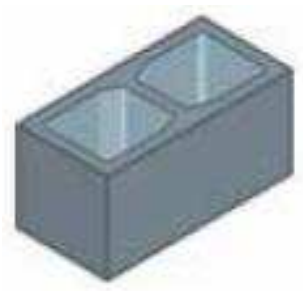

Bloco Inteiro

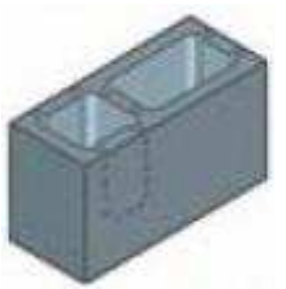

Bloco Especial 14x34

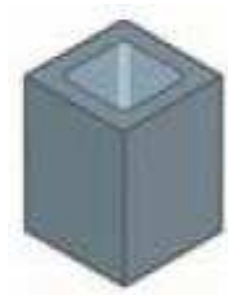

Meio Bloco

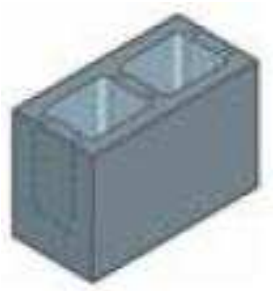

Bloco Canaleta

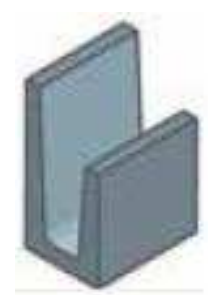

Bloco Jota

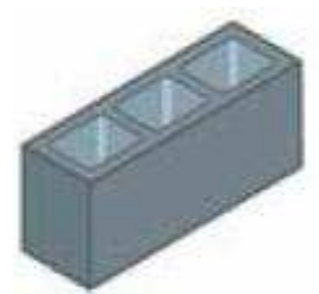

Bloco Especial 14x44 $14 \times 54$

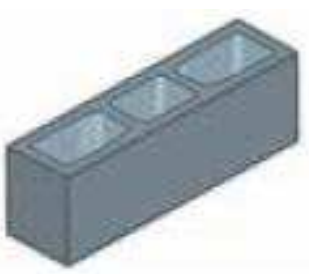

Bloco Especial

Figura 2.4 - Tipos de blocos de concreto

Fonte: Camacho/2006

Como podemos observar nas Figuras 2.4 e 2.5 existem vários modelos de blocos para diferentes aplicações, tais como:

$\times$ Bloco jota: que possui uma das laterais mais altas com a finalidade de regularizar as lajes nas paredes externas;

x Bloco canaleta: utilizado para a execução de cintas.

Além desses blocos constantes nas Figuras 2.4 e 2.5, existem outros blocos especiais, como:

× bloco $3 / 4:$ utilizado em acertos durante a modulação;

× bloco para pilar: que não possui as paredes internas facilitando a concretagem e colocação de armadura;

x bloco decorativo: como o bloco de canto para desenhos especiais. 


\subsubsection{JunTA DE ARGAMASSA}

A junta de argamassa é composta por uma pasta aglomerante e por agregados granulares. Em alguns casos, para a melhoria de algumas de suas propriedades são acrescentados aditivos.

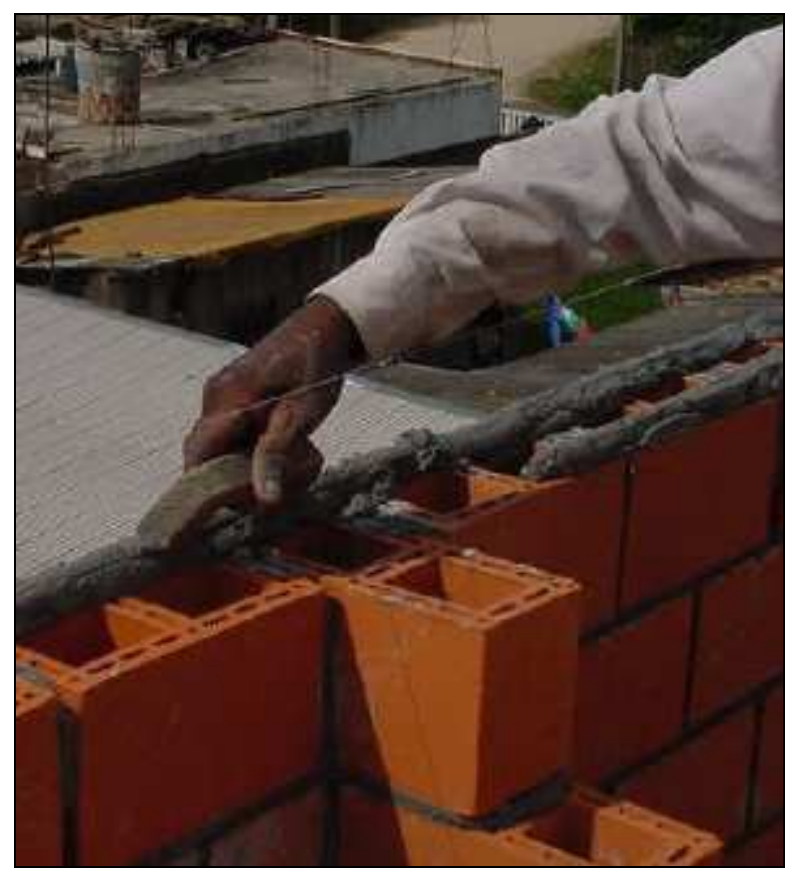

Figura 2.5 - Argamassa para assentamento dos blocos

Fonte: Roman

Suas funções básicas são solidarizar as unidades, transmitir e uniformizar tensões entre as unidades de alvenaria, absorver pequenas deformações e prevenir a entrada de água e vento nas edificações.

Para apresentar adequadamente suas funções, a argamassa deve possuir propriedades como:

x Trabalhabilidade (consistência, plasticidade e coesão): argamassa de boa trabalhabilidade é aquela que espalha facilmente sobre o bloco e aderi nas superfícies verticais. A consistência deve ser suficiente para que o bloco possa ficar prontamente alinhado, e seu peso e o das fiadas subsequientes não provoquem posterior escorrimento da argamassa;

× Capacidade de retenção de água, evitando com isso prejuízos a sua função ligante. 
× Obter resistência de forma rápida para conseguir suportar os esforços atuantes já durante a construção;

× Possuir resistência adequada ao bom funcionamento da estrutura;

× Desenvolver aderência para trabalhar em conjunto com o bloco resistindo aos esforços de cisalhamento e tração.

\subsubsection{GRAUTE}

O grauteamento é uma das técnicas mais utilizadas no reforço de alvenaria estrutural. Através do preenchimento dos vazios dos blocos tem-se um aumento da resistência da parede aos esforços de flexão, cisalhamento e compressão. Ele tem ainda a finalidade de solidarizar as unidades com as eventuais armaduras distribuídas em seus vazios.

É necessário que o graute seja feito com um concreto fluido e com agregados de pequenas dimensões, para que ele consiga preencher totalmente os vazios e envolver a armadura aderindo-a ao bloco, formando assim um conjunto único.
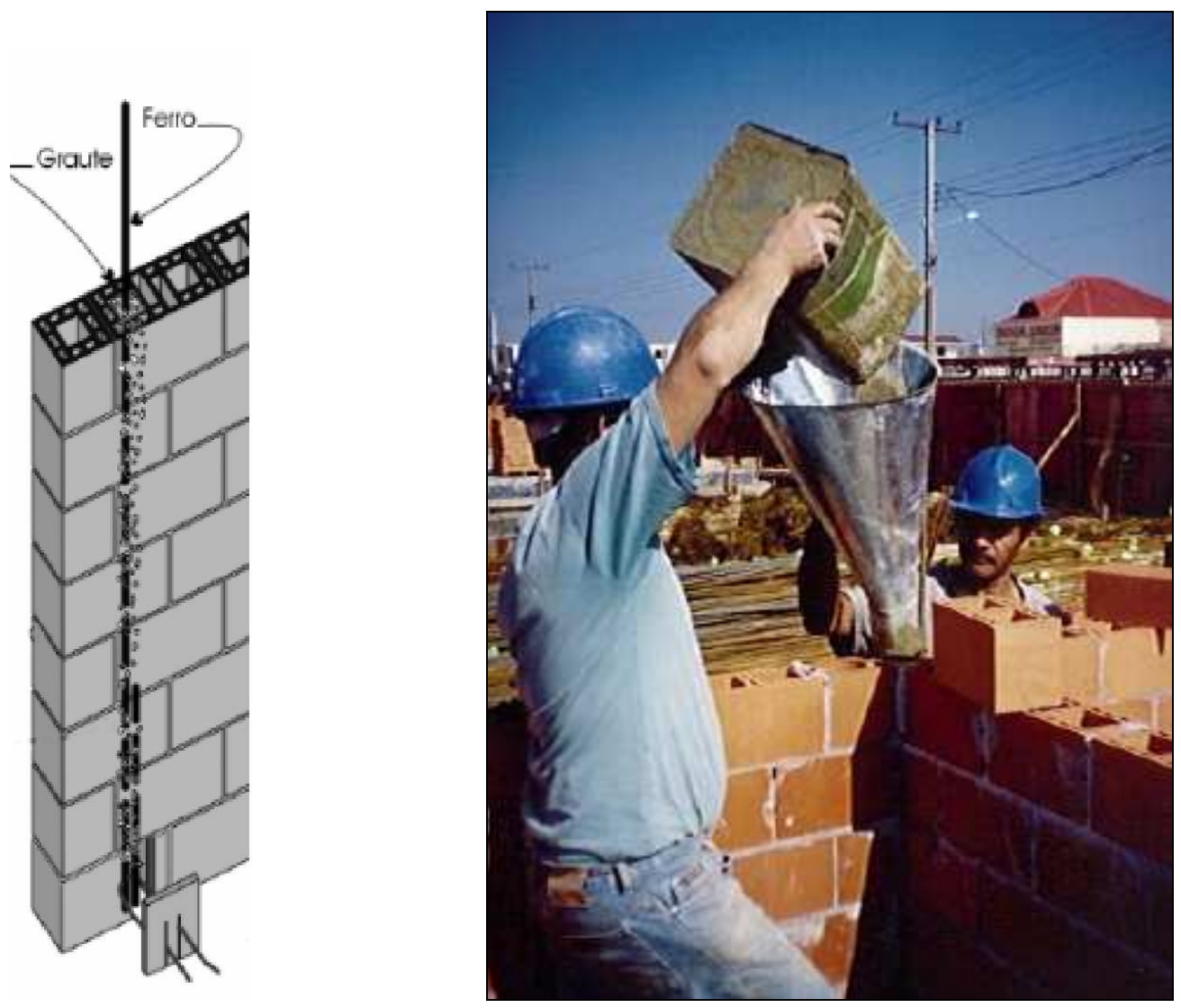

Figura 2.6 - Execução de grauteamento. Fonte: Roman 
A NBR 10837/1989 - Cálculo de alvenaria estrutural de blocos vazados de concreto - determina que a resistência característica do graute deva ser maior ou igual a duas vezes a resistência característica do bloco. Dessa forma, conclui-se que essa norma, que considera a resistência em relação à área bruta, admite um índice de vazios de $50 \%$.

\subsubsection{ARMADURAS}

As armaduras são as mesmas utilizadas no concreto armado e podem ser utilizadas para aumentar a capacidade de carga da parede, em situações específicas na alvenaria estrutural (vergas, contravergas, etc.), ou apenas de forma construtiva.

São envolvidas por graute para garantir o trabalho conjunto com os outros componentes da alvenaria.

A resistência à tração da alvenaria é muito baixa, por esse motivo a armadura pode ser utilizada na melhoraria dessa propriedade em situações em que são desenvolvidos significantes esforços de tração na estrutura. Na maioria das vezes isso não ocorre, visto que a alvenaria estrutural está submetida preferencialmente a esforços de compressão.

\subsubsection{MOdULAÇÃO}

A coordenação modular é realizada através da concordância das dimensões horizontais e verticais da edificação com as dimensões da unidade. Ela deve ser definida com medidas múltiplas ao módulo de referência, visando evitar a utilização de blocos especiais, trechos complementares e até mesmo cortes e desperdícios durante a execução da obra.

O módulo de referência tem como base a unidade a ser utilizada na edificação, onde o comprimento e a largura definem o módulo horizontal e a altura define o módulo vertical a ser utilizado. 


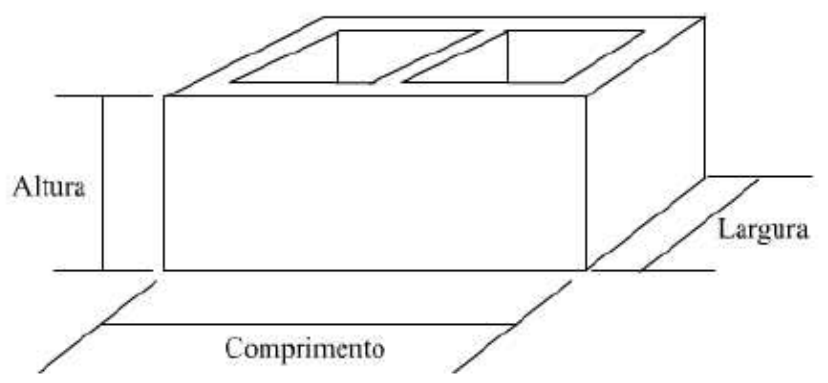

Figura 2.7 - Unidade

Para facilitar a modulação os encontros entre as paredes, aberturas, pontos de graute e ferragem, ligação laje/parede, caixas de passagem, e instalações em geral devem ser pré-estabelecidos.

A norma brasileira NBR 6136/2006 - Bloco vazado de concreto simples para alvenaria estrutural - define a padronização das dimensões dos blocos, conforme Tabela 2.1. Aceita-se uma tolerância de $\pm 2 \mathrm{~mm}$ para a largura e $\pm 3 \mathrm{~mm}$ para a altura e comprimento.

\begin{tabular}{cccc}
\hline \multirow{2}{*}{ Designaçä́ } & \multicolumn{3}{c}{ Dimensöes Fadronizadas(mm) } \\
& Largura & Altura & Comprimento \\
\hline M-20 & 190 & 190 & 390 \\
M-15 & 140 & 190 & 390 \\
& 140 & 190 & 290 \\
M-12,5 & 115 & 190 & 390 \\
& 115 & 190 & 240 \\
M-10 & 115 & 190 & 365 \\
& 90 & 190 & 390 \\
M-7.5 & 90 & 190 & 190 \\
& 90 & 190 & 290 \\
\hline
\end{tabular}

Tabela 2.1 - Dimensões dos blocos 
Modulaçẫo típica sen blocos especiais

Farrilia $15 \times 30$ e $20 \times 40$

* 3 juntas à prumo

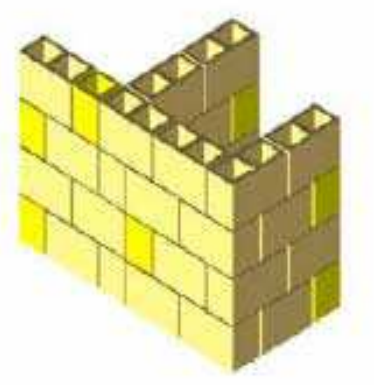

$1 / 2$ Bloco

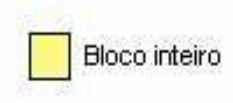

Modulaçẫo típica da farnilia $15 \times 30$

Com bloco especial de $15 \times 45$

* Sern juntas à prumo
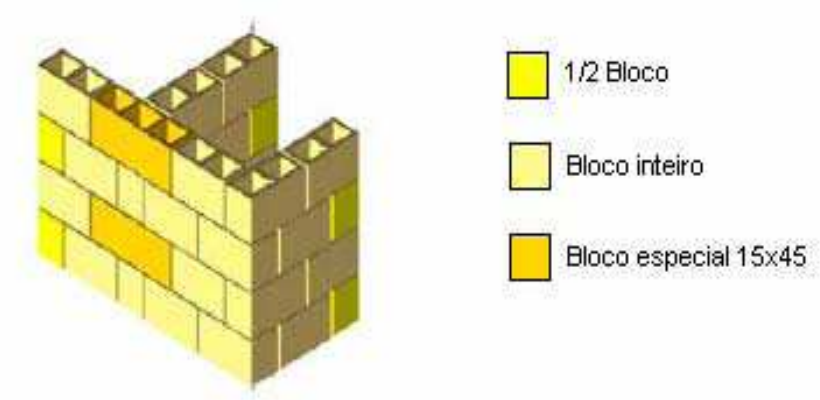

Modulaçẫo típica da farnilia $15 \times 40$

Com blocos especiais de $15 \times 35$ (L/T) e $15 \times 55$ (T) *Sen juntas à prumo

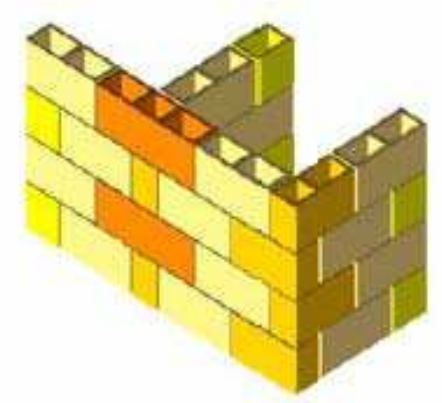

$1 / 2$ Bloco

$\square$ Bloco inteiro

Bloco especial $15 \times 35$

Bloco especial $15 \times 55$

Figura 2.8 - Desenho dos tipos de amarrações de blocos. Fonte: Camacho/2006

\subsubsection{FATORES QUE AFETAM A RESISTENNCIA}

A alvenaria estrutural possui geralmente uma boa resistência à compressão, mas para isso alguns fatores isolados tais como resistência das unidades e da argamassa, qualidade da mão-de-obra e geometria dos elementos devem ser satisfeitos de forma a garantir a resistência do conjunto.

\subsubsection{RESISTENCIA DAS UNIDADES}

A resistência das unidades é o principal fator na resistência à compressão de prismas e paredes de alvenaria, principalmente quando não possuem grauteamento. Aumentando-se a resistência à compressão das unidades geralmente aumenta-se a da alvenaria, mesmo que não ocorra na mesmo proporção. 
Segundo Fahmy e Ghoneim (1995) (apud Freitas/2008) para aumentando-se a resistência de blocos, tem-se um aumento muito pequeno resistência de prismas não grauteados.

Diante dessa diferença temos o fator de eficiência $(\eta)$ que é a relação entre a resistência da alvenaria e a resistência da unidade. Esse fator é utilizado para fazer uma previsão da resistência da alvenaria com base no valor de resistência do bloco.

\subsubsection{RESISTÊNCIA DA ARGAMASSA}

Segundo Khalaf et al. (1994) (apud Alves/2008), em prismas não grauteados para aumentar uma parcela pequena de sua resistência deve-se ter um aumento muito maior na resistência da argamassa. Em prismas grauteados dobrando-se a resistência da argamassa consegue-se apenas um aumento quase insignificante no prisma.

Com isso, notamos que a resistência à compressão da junta de argamassa tem pouca influência sobre a resistência da alvenaria, principalmente com o uso de blocos de concreto e graute. No entanto, quando muito fraca pode provocar a ruptura da alvenaria por seu esmagamento.

Segundo Gomes (1983) (apud Alves/2008), outro fator a ser levado em consideração é o fato de que argamassas muito resistentes não possuem ductilidade suficiente para acomodar a estrutura diante dos esforços, o que pode resultar numa ruptura frágil.

A forma de assentamento dos blocos também influencia na resistência, pois assentamentos em que a argamassa é colocada apenas nos septos longitudinais, causam concentrações de tensões que podem reduzir a resistência do prisma.

\subsubsection{QUALIDADE DA MÃO-DE-OBRA}

Os principais fatores relacionados à mão-de-obra e que devem ser controlados durante a montagem da alvenaria são:

x Controle da argamassa: a argamassa deve ser tratada como parte integrante da estrutura, visto que suas propriedades influenciam na resistência da 
alvenaria. Dessa forma, devem-se determinar suas características necessárias, tais como resistência, trabalhabilidade e retenção de água, conforme especificação do projeto, evitando quaisquer tipos de alterações.

× Assentamento incorreto: a argamassa deve possuir espessura o mais uniforme possível e as juntas devem ser completamente preenchidas.

× Perturbação das unidades após o assentamento: a perturbação é causada por práticas como batidas nas unidades para correção de erros de prumo. Elas podem prejudicar as condições de aderência entre as unidades e a argamassa e produzir fissuras na argamassa, influenciando na resistência final da alvenaria.

× Prumo da parede: excentricidades causadas pela construção de paredes fora do prumo ou fora de alinhamento, quando são de diferentes pavimentos, reduzem a capacidade resistente da estrutura.

Segundo Camacho (apud Landini/2001), foi realizado um estudo comparativo pelo "National Bureau of Standards", entre uma mão-de-obra considerada comercial e outra especializada, utilizando-se tijolos de resistência entre 20 e $28 \mathrm{MPa}$. As paredes construídas com a mão-de-obra especializada obtiveram resistências superiores às paredes construídas com a mão-de-obra comercial em torno de 60 e $80 \%$.

Com isso, verificamos que a mão-de-obra necessária para a execução da alvenaria estrutural tem grande influência em sua resistência à compressão.

\subsubsection{Geometria dos Elementos}

A geometria é um dos fatores que influencia na diferença de resistências das unidades. Isso é confirmado, segundo Barbosa/2004, em ensaios realizados por Render (1986) onde a resistência dos blocos de altura de $100 \mathrm{~mm}$ foi cerca de $43 \%$ a $60 \%$ maior que a resistência dos de altura entre 150 e 200 mm. Essa diferença ocorre, pois à variação da altura dos elementos influencia no efeito do confinamento.

Ainda segundo Barbosa/2004, com base nesses resultados, pôde-se concluir que variando apenas a altura e mantendo constantes as demais variáveis de um bloco, serão encontradas unidades menos resistentes quanto maior for sua relação h/t. 
Alguns outros fatores, tais como espessura das juntas de argamassa, absorção inicial de água da unidade e condições de cura também influenciam na resistência da alvenaria mas com menor intensidade.

\subsection{Patologias em AlVenaria EStrutural}

Entre as manifestações patológicas mais comuns em alvenaria estrutural tais como fissuração, formação de eflorescência, penetração de água em fachada e descolamento de revestimento, a fissuração é a mais freqüente.

Isso ocorre, pois a cerâmica, o concreto e as demais matérias-primas utilizadas na fabricação de blocos e tijolos, assim como a argamassa de assentamento são materiais frágeis e de baixa resistência à tração. Como a alvenaria é um conjunto de unidades unidas por juntas de argamassa, ela apresenta essas mesmas características. Além disso, a resistência a tração nas interfaces entre as unidades e a argamassa é muito baixa, podendo causar à separação entre elas.

As fissuras podem ser causadas por diversos fatores, tais como: baixo desempenho às solicitações de tração, flexão e cisalhamento apresentado pelos componentes da alvenaria, retração da argamassa, diferenças entre as propriedades (resistência mecânica, módulo de deformação longitudinal, coeficiente de Poisson, dilatação térmica, etc.) dos materiais constituintes, recalque de fundação, etc.

Classificar as fissuras de acordo com a abertura, espaçamento e, quando possível, a época de ocorrência em relação à execução e descobrir suas causas auxiliam de forma significativa à identificação de sua origem e definição de um tratamento adequado para a recuperação da alvenaria.

Grande parte dos problemas de desempenho das construções poderia ser evitada com a utilização de materiais, técnicas, procedimentos e normas adequadas.

Segundo, Cheema e Klingner (1986) (apud Freitas/2008) as rupturas tanto em alvenaria grauteada como em alvenaria não grauteada de blocos de concreto ocorrem pelos seguintes fatores: 
× Fendilhamento lateral do bloco: quando a resistência à tração do bloco é inferior a solicitada, causando a sua ruptura;

× Esmagamento da argamassa: quando a resistência à compressão da junta de argamassa é inferior a solicitada, causando seu esmagamento;

× Esmagamento do bloco: quando a resistência à compressão do bloco é inferior a solicitada, causando seu esmagamento;

× Fendilhamento da argamassa: quando a resistência à tração da argamassa é inferior a solicitada;

× Esmagamento do graute: quando a resistência à compressão confinada do graute é inferior a solicitada.

As fissuras podem se desenvolver nas direções horizontal, vertical, diagonal ou uma combinação destas. Quando a resistência à tração da unidade for inferior à resistência à tração da argamassa a fissura ocorrerá de forma retilínea, caso contrário ocorrerá de forma escalonada. Essa forma pode ainda sofrer influência de outros fatores como rigidez relativa das juntas com relação às unidades, restrições da parede, existência de aberturas ou outros pontos frágeis e a causa da fissura.

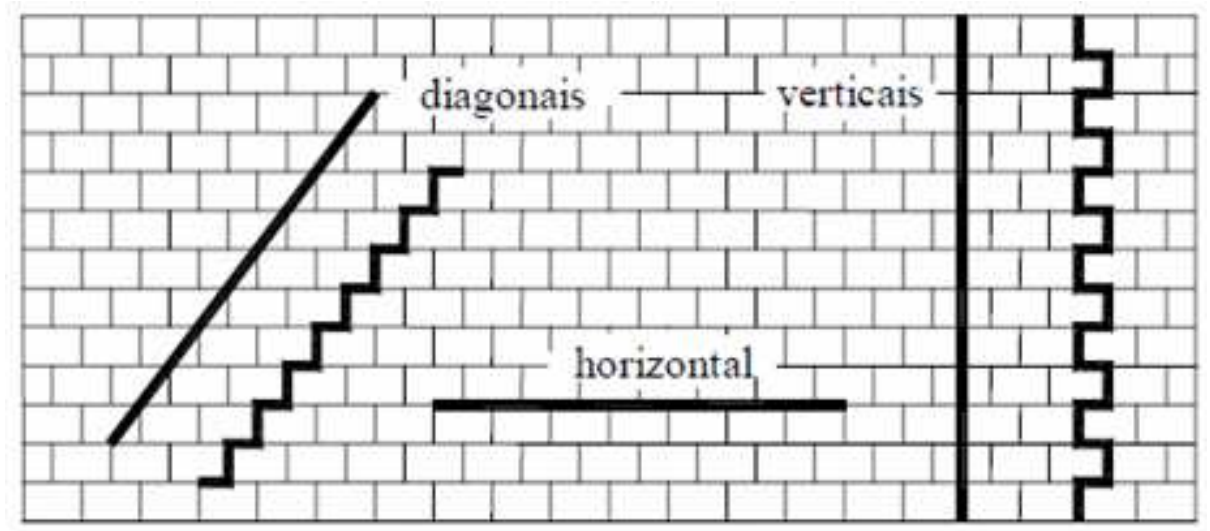

Figura 2.9 - Configurações básicas das fissuras em alvenaria. Fonte: Holanda/2002 

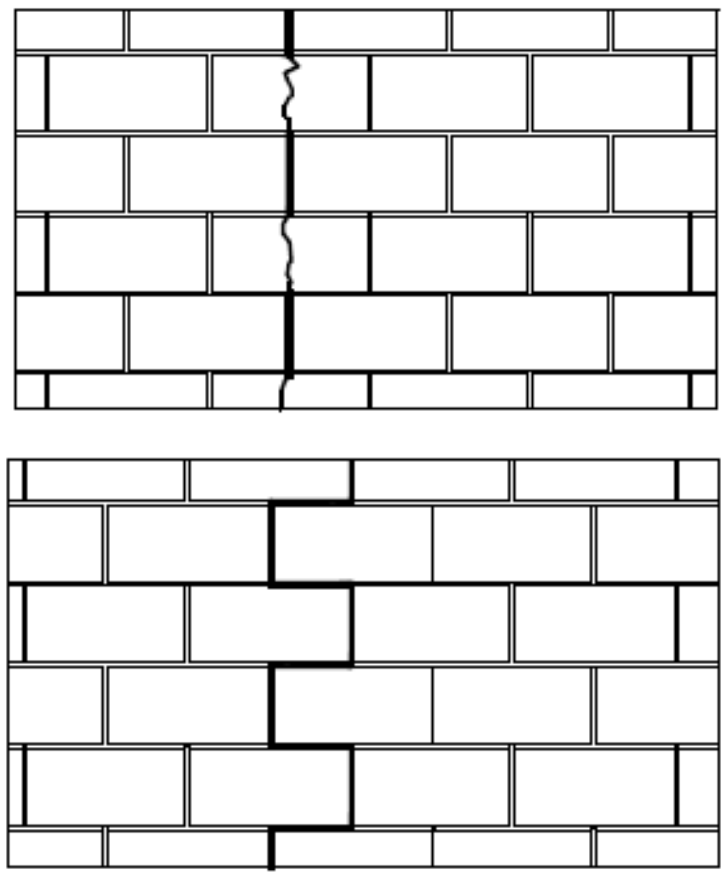

Figura 2.10 - Ruptura retilínea e escalonada. Fonte: Oliveira/2001

\subsubsection{CLASSIFICAÇÃO DAS FISSURAS QUANTO ÀS CAUSAS}

As fissuras em alvenarias estruturais são manifestações devido à perda de desempenho, causadas por fatores como:

\subsubsection{Carregamento EXCESSIVO DE Compressão}

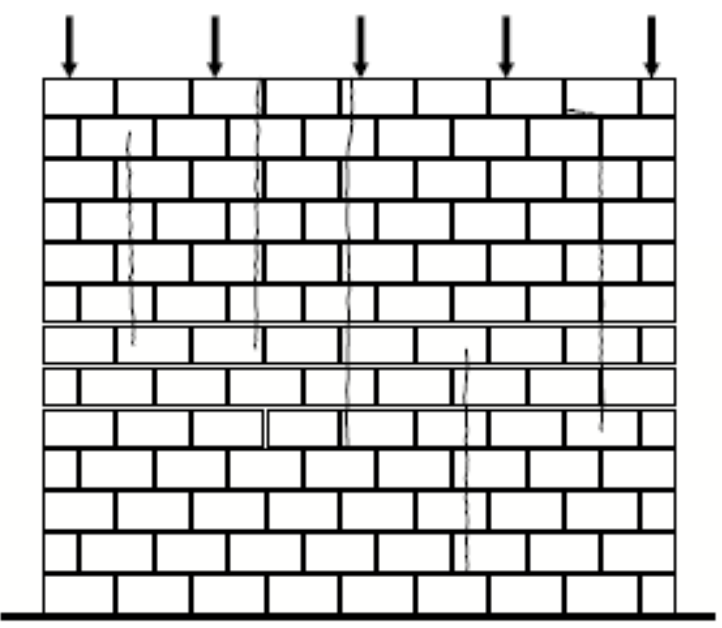

Figura 2.11 - Foto do caderno técnico de alvenaria estrutural. Fonte: Bauer 
Fissuras causadas por carregamento excessivo de compressão geralmente são verticais, e segundo Duarte/1998 (apud Richter/2007) são decorrentes de esforços transversais de tração induzidos nas unidades pelo atrito da superfície da junta de argamassa com a face das unidades.

Mesmo que em menor intensidade que as unidades a argamassa se deforma devido à compressão tendendo a se expandir lateralmente transmitindo assim tração lateral às unidades causando as fissuras verticais.

De forma geral, as fissuras em alvenarias carregadas axialmente começam a surgir antes de serem atingidas as cargas-limite de ruptura.

Sempre que ocorrer a aplicação de cargas verticais concentradas deve ser feita uma distribuição dos esforços através de coxins ou outros elementos. Quando isso não é realizado de forma correta poderão ocorrer esmagamentos localizados e formação de fissuras desde o ponto de aplicação da carga.

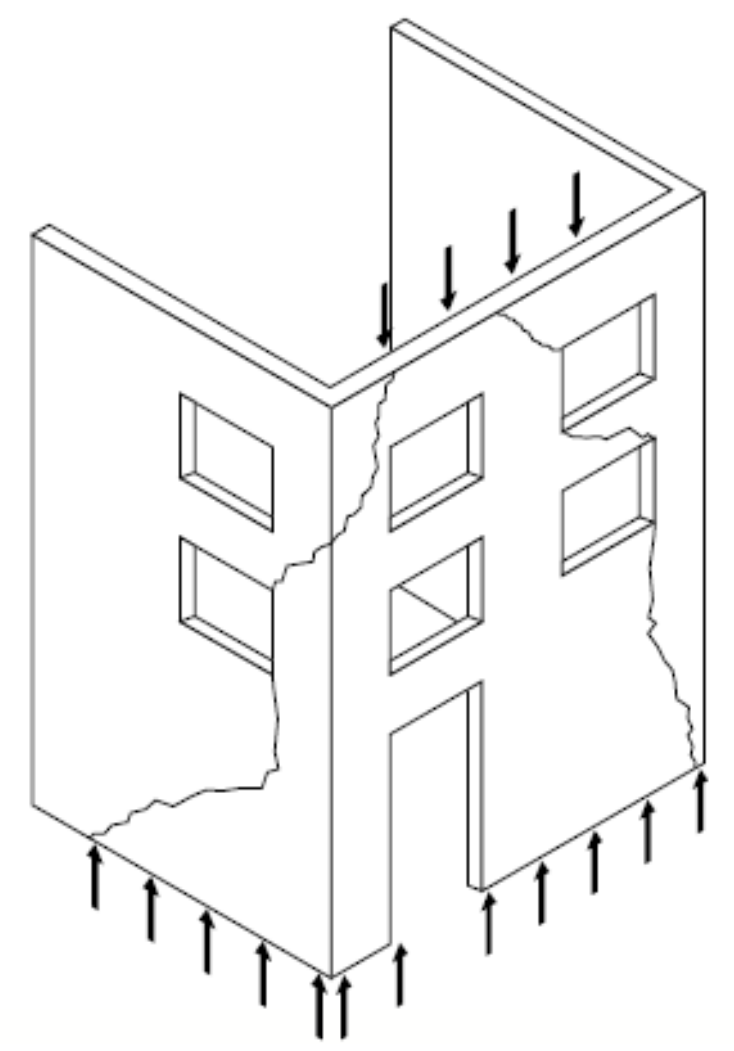

Figura 2.12 - Esmagamento em pontos localizados. Fonte: Bauer 
Esse esmagamento em pontos localizados pode produzir ruptura dos componentes da alvenaria, provocando o surgimento de fissuras inclinadas a partir da região da aplicação da carga.

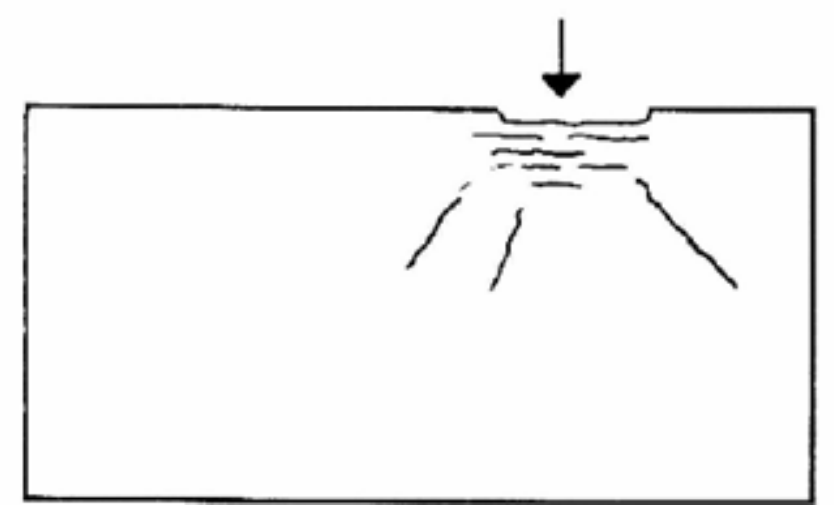

Figura 2.13 - Fissuras em alvenaria proveniente de carga concentrada . Fonte:

Thomaz/2001

Mesmo não ocorrendo de forma freqüente, solicitações provenientes de cargas uniformemente distribuídas podem causar fissuras horizontais nas alvenarias. Esse tipo de fissura ocorre pelo esmagamento da argamassa das juntas de assentamento ou solicitações de flexo-compressão.

Devido ao surgimento de esforços de flexão lateral provenientes de uma excessiva deformação de lajes ancoradas em paredes podem surgir fissuras nas proximidades da base da laje, conforme a Figura 2.14.

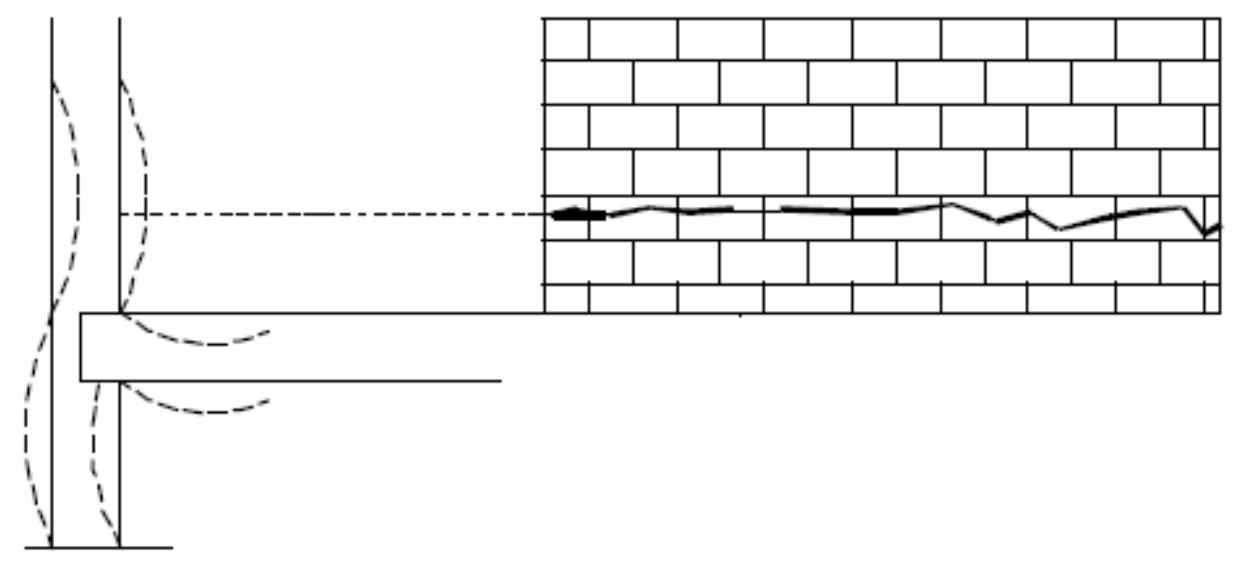

Figura 2.14 - Fissuras causadas pela excessiva deformação da laje. Fonte: Oliveira/2001 
Em paredes com aberturas de portas e janelas, ocorre considerável concentração de tensões no contorno dos vãos. Por esse motivo é comum o aparecimento de fissuras a partir dos vértices das aberturas e sob o peitoril das janelas.

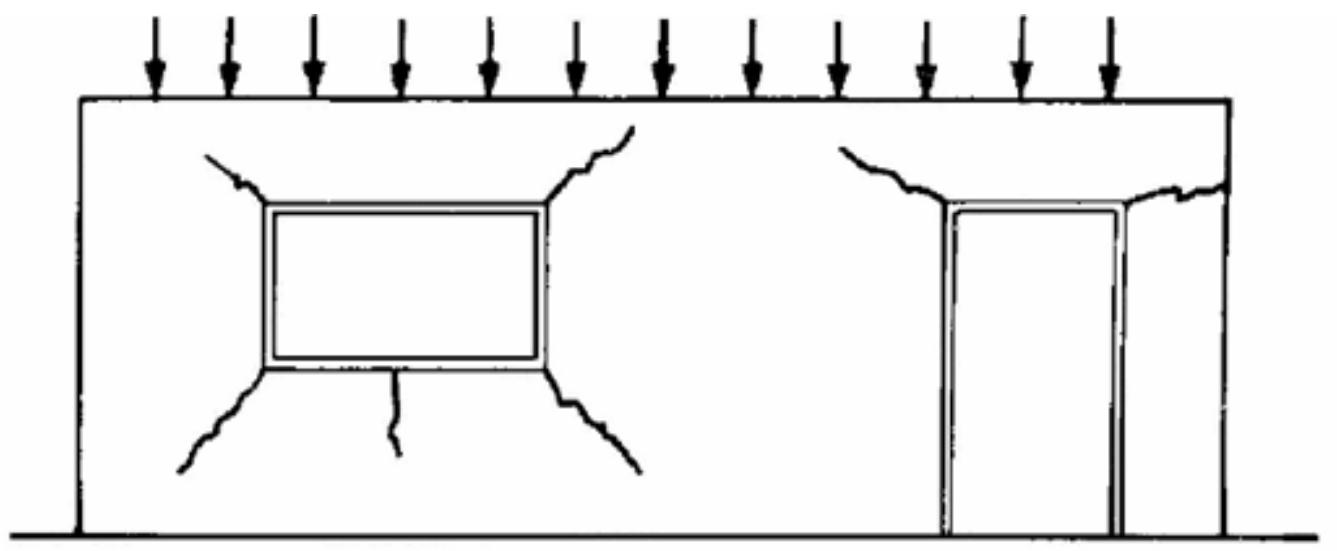

Figura 2.15 - Fissuras devido a concentração de tensões no contorno dos vãos. Fonte: Bauer

\subsubsection{RETRAÇÃO}

Segundo Scartezini/2002 (apud Richter/2007), a retração é um fenômeno físico onde os materiais com base cimentícia, inicialmente em estado plástico, têm uma redução de seu volume causado pelas condições de umidade do sistema e a evolução da matriz do cimento.

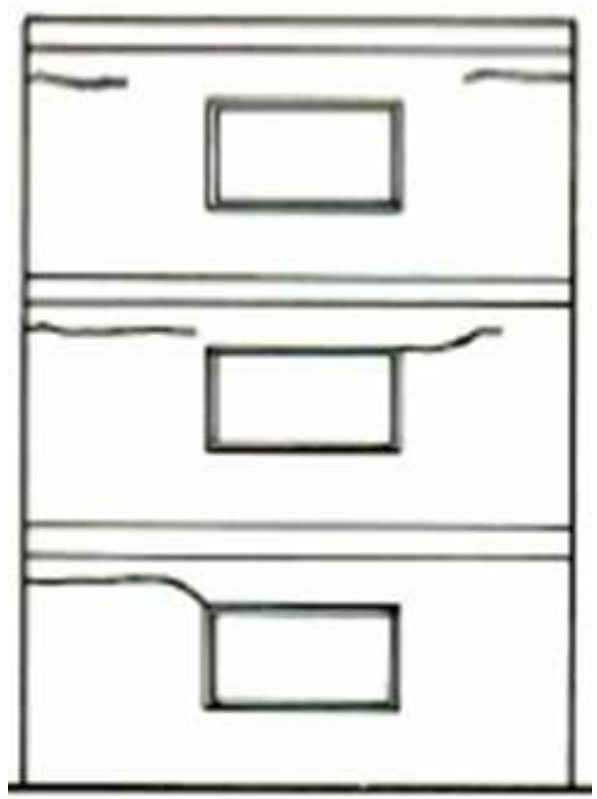

Figura 2.16 - Fissuras causadas pela retração de lajes. Fonte: Bauer 
Essa retração pode causar fissuração devido à rotação nas fiadas de blocos próximos a laje causada por seu encurtamento. Por esse motivo, a configuração mais comum de fissuras causadas por retração são as fissuras horizontais que se localizam logo abaixo das lajes ou em cantos superiores dos caixilhos.

Segundo Thomaz/1988 (apud Richter/2007), além das fissuras causadas pela retração das lajes existem as fissuras mapeadas que são fissuras de retração no revestimento em argamassa. Os principais fatores que influenciam no aparecimento desse tipo de fissura são: consumo de aglomerante, porcentagem de finos existentes na mistura e teor de água de amassamento. Além desses, outros fatores como a má aderência entre a argamassa e a base, a espessura delas, o tempo de aplicação entre uma e outra, a rápida perda de água durante o endurecimento devido a vento ou insolação também influenciam em seu aparecimento.

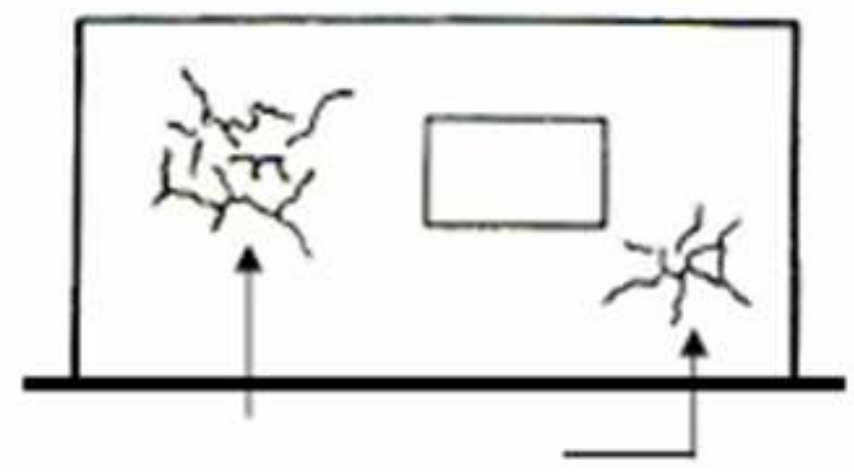

Figura 2.17 - Fissuras mapeadas . Fonte: Thomaz/2001

\subsubsection{VARIAÇÃO DE TEMPERATURA}

As movimentações térmicas estão relacionadas tanto com as propriedades físicas dos materiais quanto com o gradiente de temperatura. Por esse motivo, podem ocorrer de forma diferenciada entre materiais distintos de um mesmo componente, entre componentes distintos e entre regiões distintas de um mesmo material.

Os vínculos que envolvem os elementos e componentes das edificações restringem as movimentações térmicas promovendo o aparecimento de tensões. Dependendo da intensidade da movimentação, do grau de restrição imposto pelos vínculos e das propriedades elásticas dos materiais, podem causar fissuras.

Essas movimentações podem ocorrer em casos como: 
× Atuação de uma mesma variação de temperatura em materiais com diferentes coeficientes de dilatação térmica;

× Diferentes variações térmicas atuando num único elemento;

× Gradiente de temperatura ao longo de um mesmo componente (ex: gradiente entre a face exposta e a face protegida de uma laje de cobertura)

Devido à variação de temperatura, as fissuras horizontais decorrentes de movimentações térmicas são mais comuns em lajes de cobertura. Em lajes de cobertura sobre paredes muito longas, constituídas de aberturas de vãos de portas ou janelas, essas fissuras permanecem horizontais ao longo das paredes externas maiores inclinando-se a aproximadamente 45 graus nas paredes transversais em direção à laje de teto.
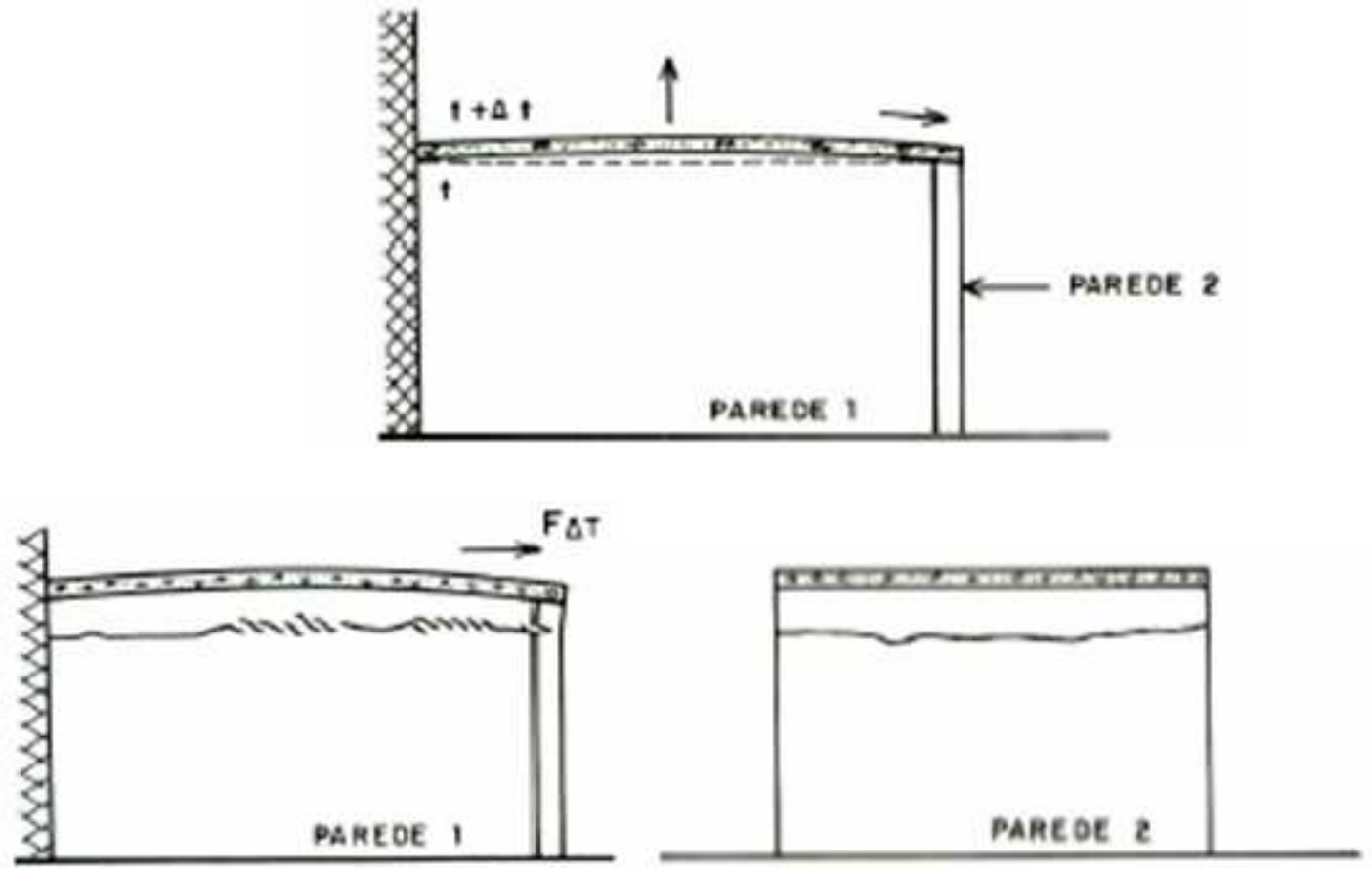

Figura 2.18 - Fissuras devido à variação de temperatura. Fonte: Thomaz/2001

As áreas mais suscetíveis à fissuração são coberturas e paredes externas por serem áreas com maior incidência de sol e conseqüente maior variação de temperatura. No entanto, as fissuras ocorrem mesmo em lajes sombreadas por telhados. 


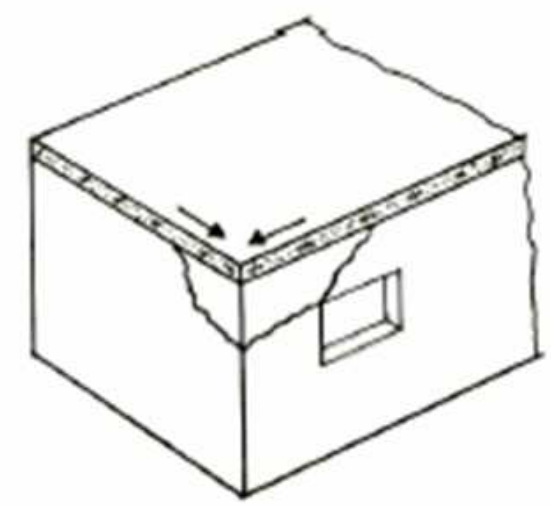

Figura 2.19 - Fissuras devido à expansão térmica da laje de cobertura. Fonte:

Thomaz/2001

\subsubsection{RECALQUE DE FUNDAÇÃo}

Conforme Thomaz/2001, os recalques podem ocorrer devido ao assentamento de fundação em seções de corte e aterro (a), rebaixamento do lençol freático em função de corte na lateral inclinada do terreno(b), influência de fundações vizinhas (c), falta de homogeneidade do solo ao longo da construção (d) e compactação diferenciada de aterros.
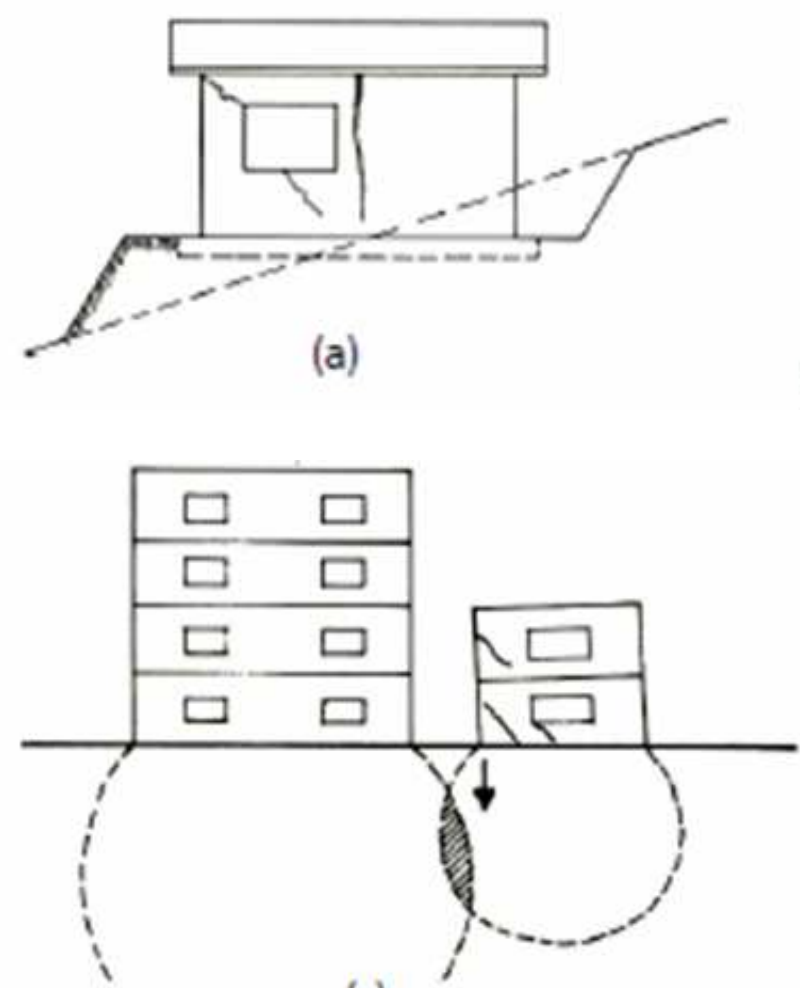

(c)
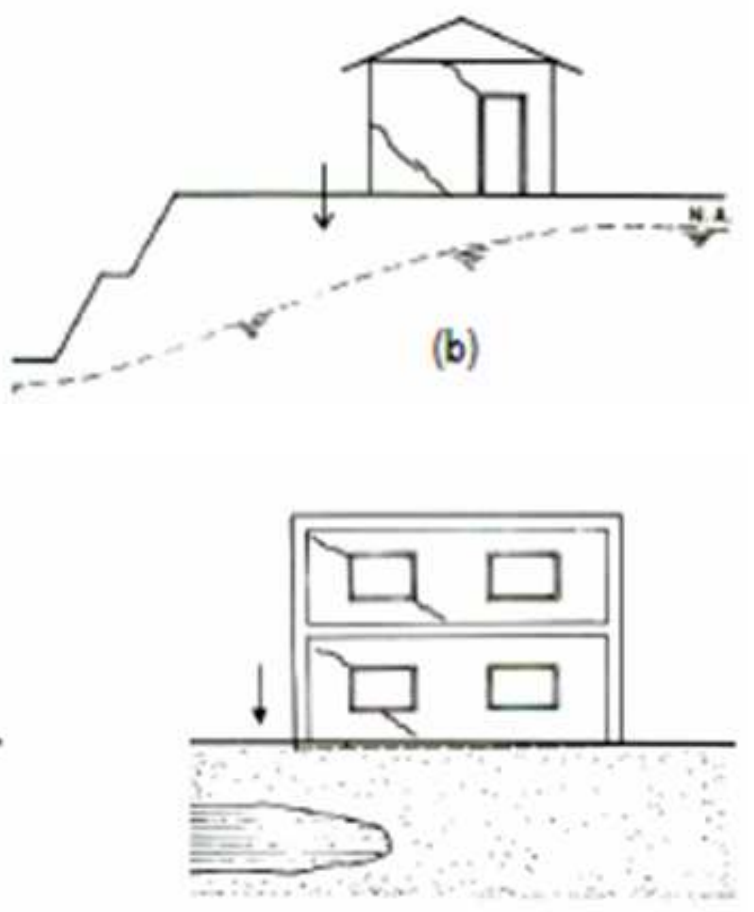

(d) 
Figura 2.20 - Fissuras devido à recalque de fundação diferenciado. Fonte:

Thomaz/2001

Esses recalques promovem o aparecimento de fissuras geralmente inclinadas ou verticais que costumam se localizar próximas ao primeiro pavimento da edificação. Dependendo da gravidade do recalque e do tipo de construção, podem ocorrer nos demais pavimentos de forma tão intensa quanto no primeiro. Quando ocorre de forma intensa as tensões de cisalhamento resultantes podem provocar esmagamentos localizados e em forma de escamas.

\subsubsection{CARREGAMENTOS DESBALANCEADos}

Carregamentos desbalanceados ocorrem devido à existência de sapatas corridas ou vigas de fundação muito flexíveis. Eles podem causar fissuras principalmente nas proximidades de peitoris de janelas, devido à sobrecarga que se concentra nessas regiões de abertura. A fissura proveniente desse tipo de carregamento se manifesta de forma vertical.

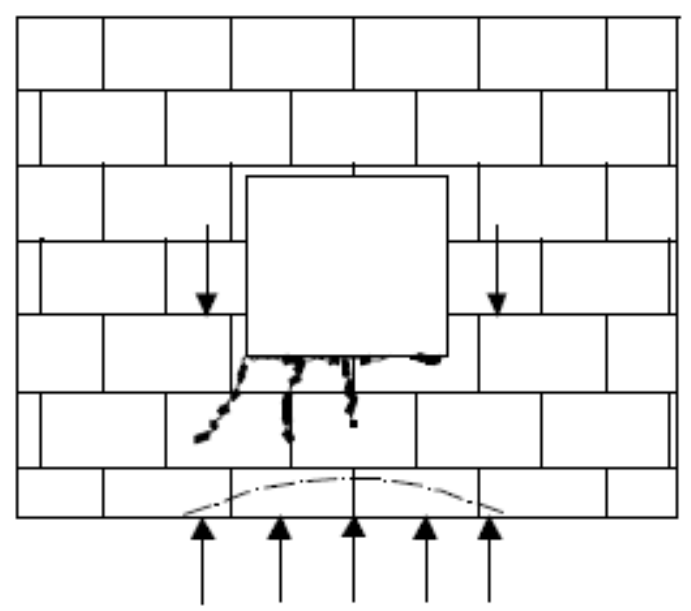

Figura 2.21 - Fissuras devido à carregamentos desbalanceados. Fonte: Thomaz/2001

\subsubsection{REAÇões Químicas}

Componentes ou elementos fabricados com cales mal hidratadas ao sofrerem umidificação ao longo de sua vida útil poderão apresentar um aumento de volume de aproximadamente $100 \%$ caso os óxidos livres hidratem. Essa expansão pode causar fissuras, descolamento, desagregações e pulverulências nos revestimentos de argamassa. 
A expansão de argamassas de assentamento pode provocar fissuras horizontais no revestimento acompanhando as juntas de assentamento da alvenaria.

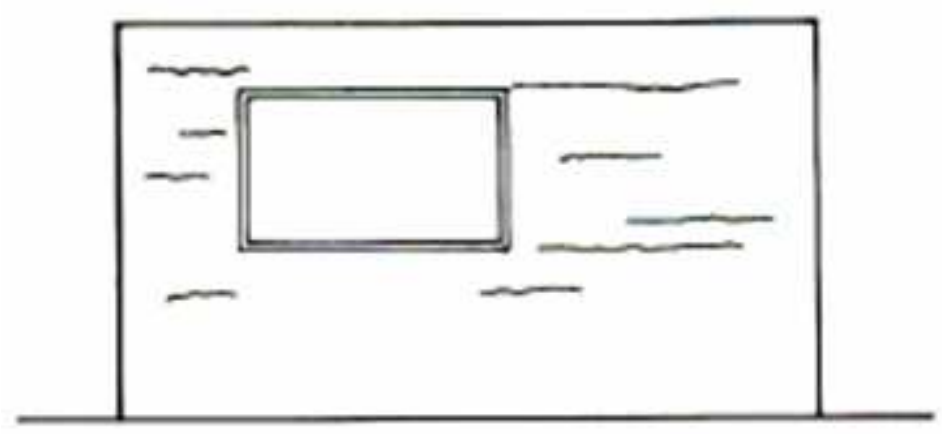

Figura 2.22 - Fissuras provocadas pela expansão da argamassa de assentamento. Fonte:

Thomaz/2001

\subsubsection{MOVIMENTAÇõES HigROSCÓPICAS}

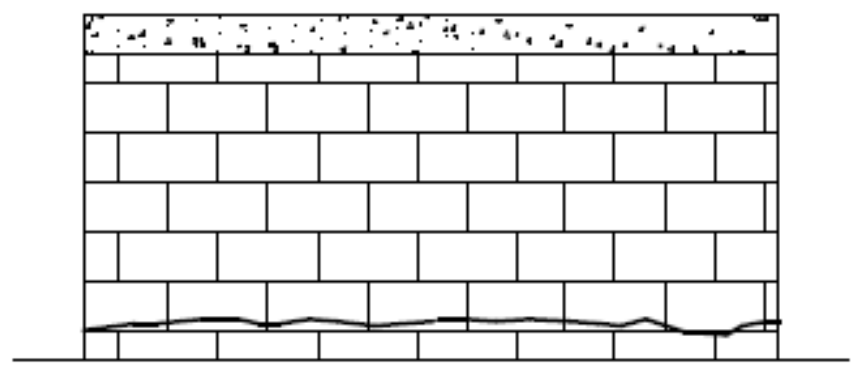

Figura 2.23 - Fissura causada por movimentações higroscópicas. Fonte: Thomaz/2001

A umidade é responsável por grande parte das fissuras horizontais da alvenaria, causadas devido à variação (contração ou expansão) de suas dimensões. Essa variação causa deformação excessiva de lajes ancoradas nas paredes produzindo esforços de flexão laterais, resultando com isso, em fissuras.

Isso ocorre com mais freqüência e até mesmo intensidade em regiões como cantos desabrigados, platibandas, base de paredes, etc. devido à maior incidência de umidade. 


\subsection{PrevenÇÃo}

Alguns cuidados devem ser tomados para evitar que fissuras ocorram devido ao carregamento efetivo. Dentre esses cuidados, temos: evitar o prejuízo das cargas excêntricas e no caso de cargas concentradas, executar um coxim para a melhor distribuição da carga.

Dentre os principais fatores que causam fissuração, temos:

× Diferença entre módulo de elasticidade e coeficiente de dilatação térmica dos materiais que compõem a laje e as paredes;

× Diferentes solicitações das ações térmicas entre laje e paredes;

× Vinculação que as paredes impõem à movimentação da laje.

O primeiro fator citado não pode ser evitado e está presente em todas as edificações, visto que a laje e as paredes são constituídas de diferentes tipos de materiais. Diante disso, pode-se considerar esse como um fator de significância secundária, principalmente quando comparado com os outros dois fatores.

Os outros fatores devem ser levados em consideração durante o projeto e execução da edificação, visando amenizar a ocorrência das fissuras.

Para reduzir as desigualdades entre as ações térmicas atuantes na laje e paredes podem ser tomados alguns cuidados, como:

x Proteger as telhas com coloração adequada visando reduzir a absorção do calor. As cores mais claras são as ideais;

x Proporcionar ventilação adequada entre a cobertura e a laje com um espaço de circulação de ar para entrada de ar frio por baixo e saída de ar quente por cima, pois isso diminui o calor passado para a laje;

× Fazer isolamento térmico da laje, que é feito com a utilização de camadas isolantes, podendo ser utilizada tanto em laje com ou sem cobertura.

Para se evitar fissuras devidas à movimentação das lajes, pode-se:

× Colocar juntas de dilatação nas lajes, tendo-se apenas o cuidado na localização das mesmas; 
× Utilizar aparelhos de apoio de borracha extrudada entre a laje e a parede, visando promover um livre deslocamento relativo entre os elementos estruturais. Elas devem ser utilizadas de forma descontínuas em pequenas placas, preenchendo-se com material inerte o espaço entre elas.
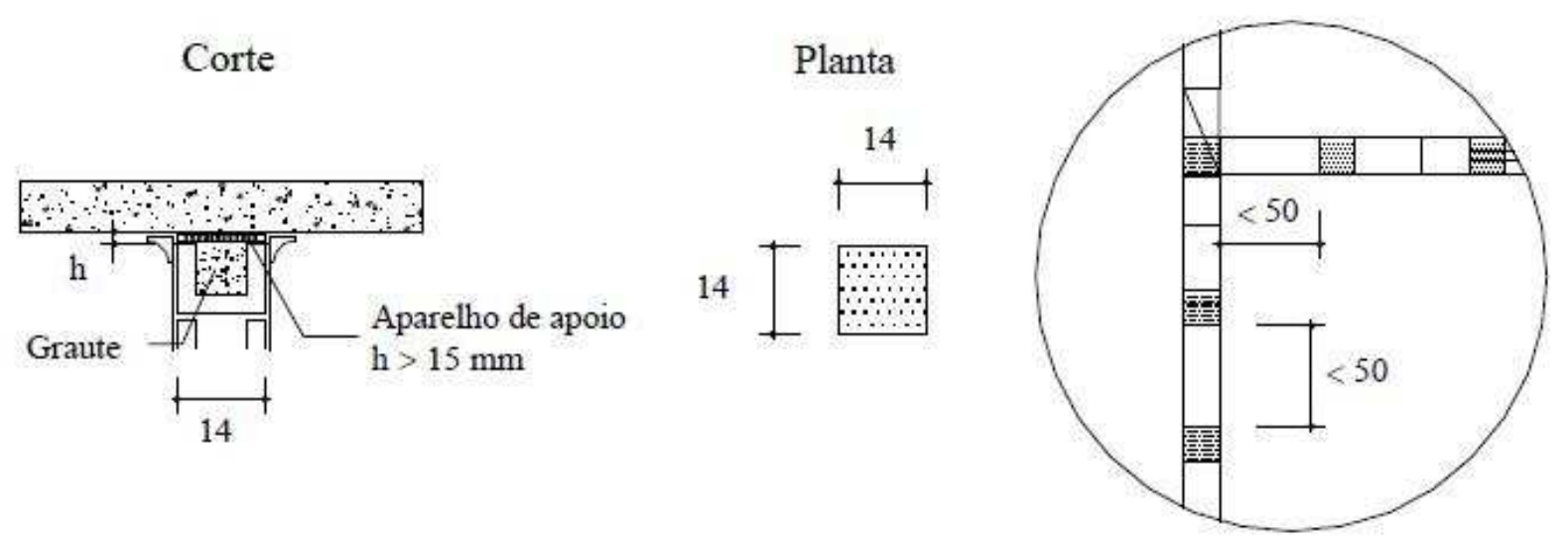

Figura 2.24 - Aparelho de apoio. Fonte: Basso

× Utilizar papel betumado ou placa de PVC na superfície em que a laje se apóia sobre a parede, pois eles atuam de forma a reduzir o coeficiente de atrito entre a laje e a parede, produzindo um plano de deslizamento. Nesse caso, a fissura que se formaria entre os blocos é transferida para a superfície de contato entre a laje e a parede.

Independente do método a ser utilizado deve-se, logo após a concretagem, realizar o isolamento térmico da laje de cobertura para evitar a ocorrência de uma dilatação precoce que possa vir a causar fissuras ainda durante a execução.

É muito comum o aparecimento de fissuras na ligação entre as paredes, sendo por isso ideal utilizar juntas com amarração direta, muitas vezes com a utilização de blocos especiais nessas ligações. Na utilização de juntas a prumo devem-se dispor ferros ou telas metálicas nas juntas de assentamentos e embuti-los nas juntas de assentamento, visto que o risco de aparecimento de fissuras é maior. 


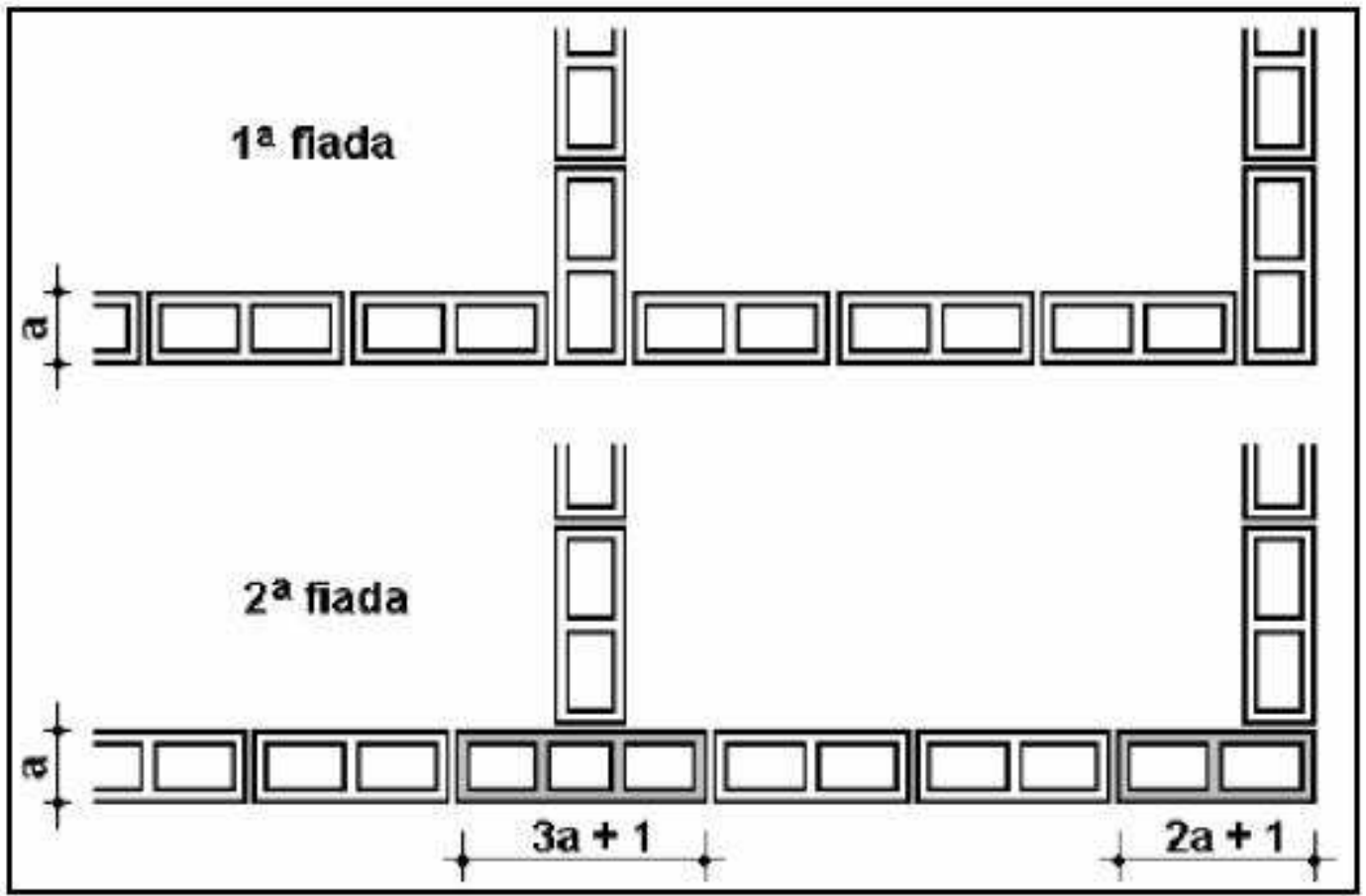

Figura 2.25 - Juntas de amarração com a utilização de blocos especiais. Fonte:

Cano/2005

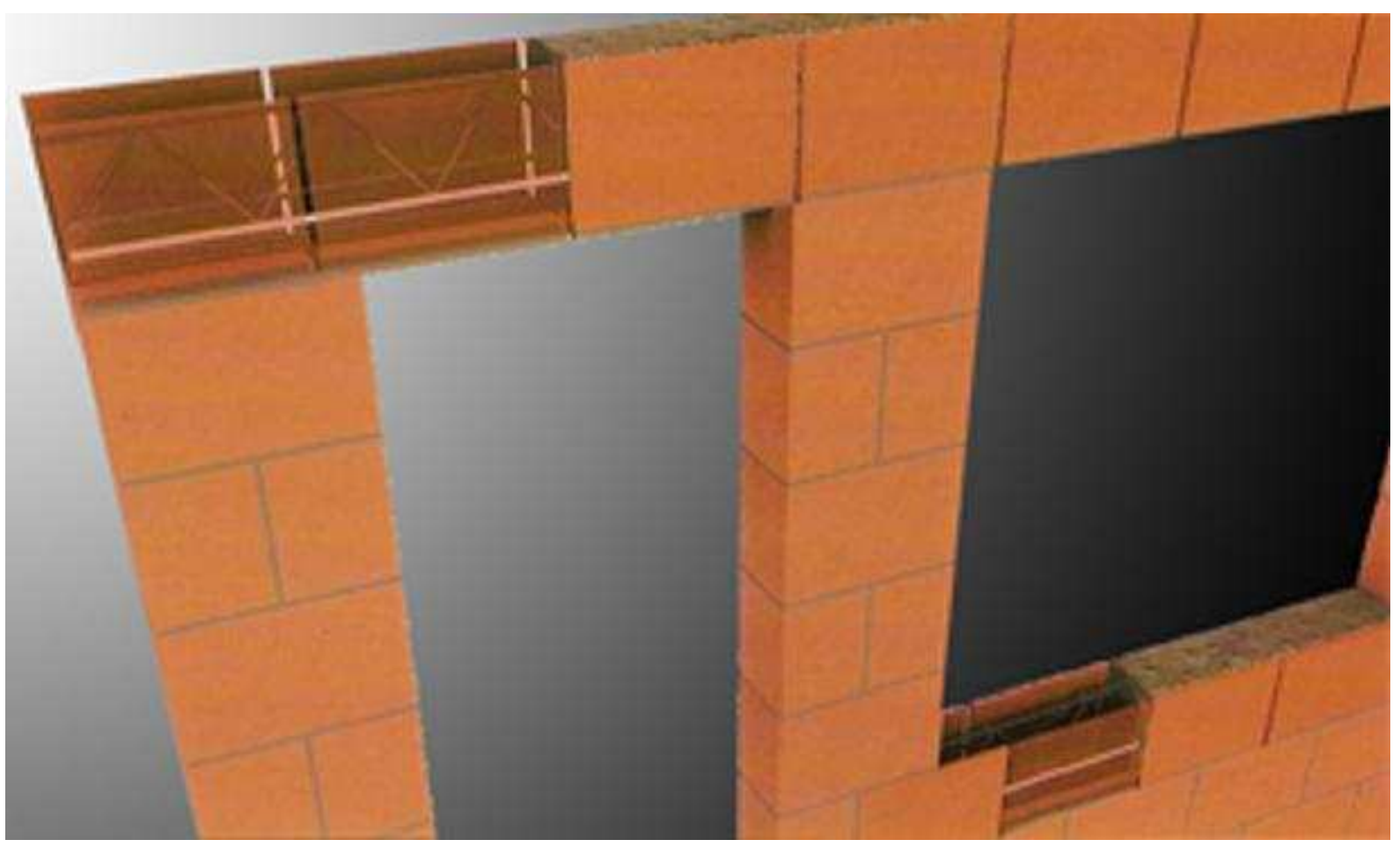

Figura 2.26 - Verga e contra-verga em alvenaria estrutural.

Fonte:www.ceramicaermida.com.br 
Outro tipo muito comum de fissura é o que ocorre no contorno de vãos de portas e janelas. Para evitar seu aparecimento devem-se utilizar vergas e contravergas dimensionadas a suportar e redistribuir as concentrações de cargas. Elas são executadas utilizando-se canaletas preenchidas com concreto armado passando no mínimo $30 \mathrm{~cm}$ das aberturas.

\subsection{REFORÇO E RECUPERAÇÃO DA ESTRUTURA}

O reforço ou reabilitação de uma alvenaria estrutural deve ser feito de forma minuciosa, realizando-se para isso uma rigorosa análise. Nessa análise deve-se identificar as causas das anomalias e avaliar a segurança estrutural para assim escolher a melhor forma de intervenção.

$\mathrm{Na}$ análise preliminar é realizado um estudo histórico da edificação visando coletar informações sobre técnicas e fases da construção, materiais utilizados e possíveis formas de utilização do edifício.

Em seguida, inicia-se o processo de análise das manifestações patológicas através de um levantamento que visa identificar os locais onde elas se encontram, suas características e suas possíveis causas.

Nessa etapa são verificados possíveis desvios de verticalidade, o estado de tensão da estrutura, a segurança, e quaisquer outros fatores que possam auxiliar na identificação e origem dessas manifestações patológicas. Para isso, deve ser feito um mapeamento detalhado dos danos visíveis, deformações, esmagamentos, deteriorização dos materiais e/ou das ligações entre os elementos estruturais, etc.

As manifestações patológicas podem ocorrer tanto pelo comportamento do material quanto pelo comportamento estrutural. É importante que isso seja identificado para a melhor escolha de reforço ou reabilitação.

Finalizada essa etapa de identificação deve-se estudar a melhor forma de intervir na estrutura analisada. Para isso é necessário elaborar um projeto de reforço ou reabilitação com técnicas e materiais que melhor se adéquem à situação. 
Alguns fatores devem ser levados em conta nessa fase de projeto, dentre eles temos:

× Restabelecimento das condições de segurança, quando necessário;

× Melhoramento das características mecânicas;

× Compatibilização entre as técnicas e materiais a serem utilizados e as características da rigidez da construção e do funcionamento estrutural original;

× Durabilidade;

* Retratibilidade para que, caso haja necessidade da retirada desse material para a colocação de um novo, ele possa ser retirado sem prejudicar a estrutura anteriormente existente.

Dentre as principais formas de reforço e reabilitação em paredes de alvenaria estrutural, temos:

* Argamassa armada:

Consiste na aplicação de argamassa forte juntamente com uma tela de aço na superfície da alvenaria. Sua utilização traz como conseqüência a redução do índice de esbeltez, o aumento da resistência à compressão e às cargas transversais.

x Rebocos armados:

Consiste na colocação de uma armadura de reforço fixada à parede juntamente com uma argamassa tradicional de revestimento. Sua utilização é indicada em casos em que as paredes estejam fortemente degradadas. (Roque/2002)

× Substituição de elementos degradados:

Consiste no desmonte e reconstrução de alguns elementos da alvenaria.

× Fechamento das juntas:

Consiste na remoção parcial e substituição da argamassa degradada por outra de maior durabilidade e de melhores propriedades mecânicas. Para 
isso, podem-se utilizar armaduras de reforço na argamassa das juntas horizontais. Sua utilização é indicada para o controle do fendilhamento devido às forças excessivas de compressão, assentamentos diferenciais, ações térmicas, etc. (Roque/2002)

× Grauteamento vertical:

Consiste na injeção de graute em furos verticais ao longo de toda a altura da parede, podendo ainda ser adicionadas barras de aço, visando aumentar a resistência à compressão, aos esforços de flexão e cisalhamento. Sua utilização é válida tanto para reforço e reabilitação quanto em obras novas.

× Injeção de graute ou resina epóxi expansiva:

Consiste na injeção de resina epóxi, utilizada geralmente em pequenas aberturas $(<2 \mathrm{~mm}$ de largura) ou de graute de argamassa de cimento, utilizada geralmente em aberturas maiores. Visa preencher fissuras, trincas e os vazios presentes na alvenaria devido à sua deterioração física e química e/ou ações mecânicas. (Chagas/2005)

x Protensão:

Consiste na inserção de barras de aço nos furos dos blocos ao longo da alvenaria, grauteadas apenas na base para que elas possam se deformar quando solicitadas. Essas barras são protendidas na direção vertical com cordoalhas, barras e cabos de aço. (SHRIVE et al., 2001, apud Chagas/2005)

× Adição de vigas e colunas de aço:

Consiste na adição de elementos estruturais, tais como vigas e pilares, visando aumentar a resistência e rigidez de paredes de alvenaria estrutural.

Existem casos onde é impossível a reabilitação ou reforço da estrutura de alvenaria, ou mesmo muito onerosa, mas é necessária a preservação arquitetônica e patrimonial. Para esses casos têm-se a opção de utilizar vigas e pilares de aço dispostos de forma a trabalhar como uma estrutura 
totalmente independente, substituindo assim a estrutura existente. (Chagas/2005)

× Reforço com materiais compósitos FRP:

Consiste na aplicação de materiais polímeros reforçados com fibras de carbono, de vidro, etc., colados ao suporte com resinas de elevado desempenho. É utilizado em casos em que se tenha necessidade de melhorar à resistência à tração, em edifícios sujeitos a abalos sísmicos, em edifícios muito altos, ou onde se deve levar em consideração a atuação do vento. (Roque/2002)

× Soluções mistas:

Consiste na utilização de mais de um dos métodos para o reforço ou reabilitação da alvenaria estrutural. 


\section{FisSURAS OBSERVADAS EM EdIFÍ́cIOS RESIDENCIAIS}

Um trabalho de campo constituído de um levantamento de manifestações patológicas em edifícios residenciais em alvenaria estrutural, mais especificamente fissuras, foi realizado na cidade de São Carlos/SP.

Esse levantamento teve por objetivos:

× Identificar edifícios residenciais em utilização a mais de cinco anos, como sendo de alvenaria estrutural;

× Buscar informações junto aos responsáveis pelos mesmos, a respeito da existência de fissuras;

× Localizar e registrar, através de fotos, fissuras presentes na parte externa e/ou social interna (escadas e corredores que dão acesso aos apartamentos).

Para a amostragem deste trabalho foram escolhidos cinco edifícios, para os quais foi identificada a existência de diversos tipos de fissuras, tais como:

× Fissuras presentes no contorno dos vãos de portas e janelas;

× Fissuras horizontais no encontro de laje com parede;

x Fissuras mapeadas;

× Fissuras horizontais, que surgem na base da alvenaria;

× Fissuras horizontais à meia altura;

Os edifícios foram analisados somente em suas partes externas e sociais internas devido à dificuldade encontrada para entrar nos apartamentos dos condôminos.

É importante ressaltar que esse trabalho de campo visa apenas realizar um levantamento das fissuras mais comuns aos edifícios observados e não uma análise mais específica dos motivos que originaram cada uma delas. Diante disso, teremos no mínimo 
duas opções de formas de ocorrências, onde uma sempre será a ruptura da argamassa de revestimento, e a outra poderá tanto ser ruptura da argamassa de assentamento como ruptura do bloco, dependendo da configuração de cada uma delas.

Nas figuras que mostram as fissuras optou-se por apresentar a foto original sem alteração nenhuma e logo em seguida uma foto onde a fissura foi ressaltada através do programa PHOTOSHOP para uma melhor visualização do seu caminhamento.

\subsection{EDIFÍ́CIOS ANALISADOS}

\subsubsection{Edifício A}

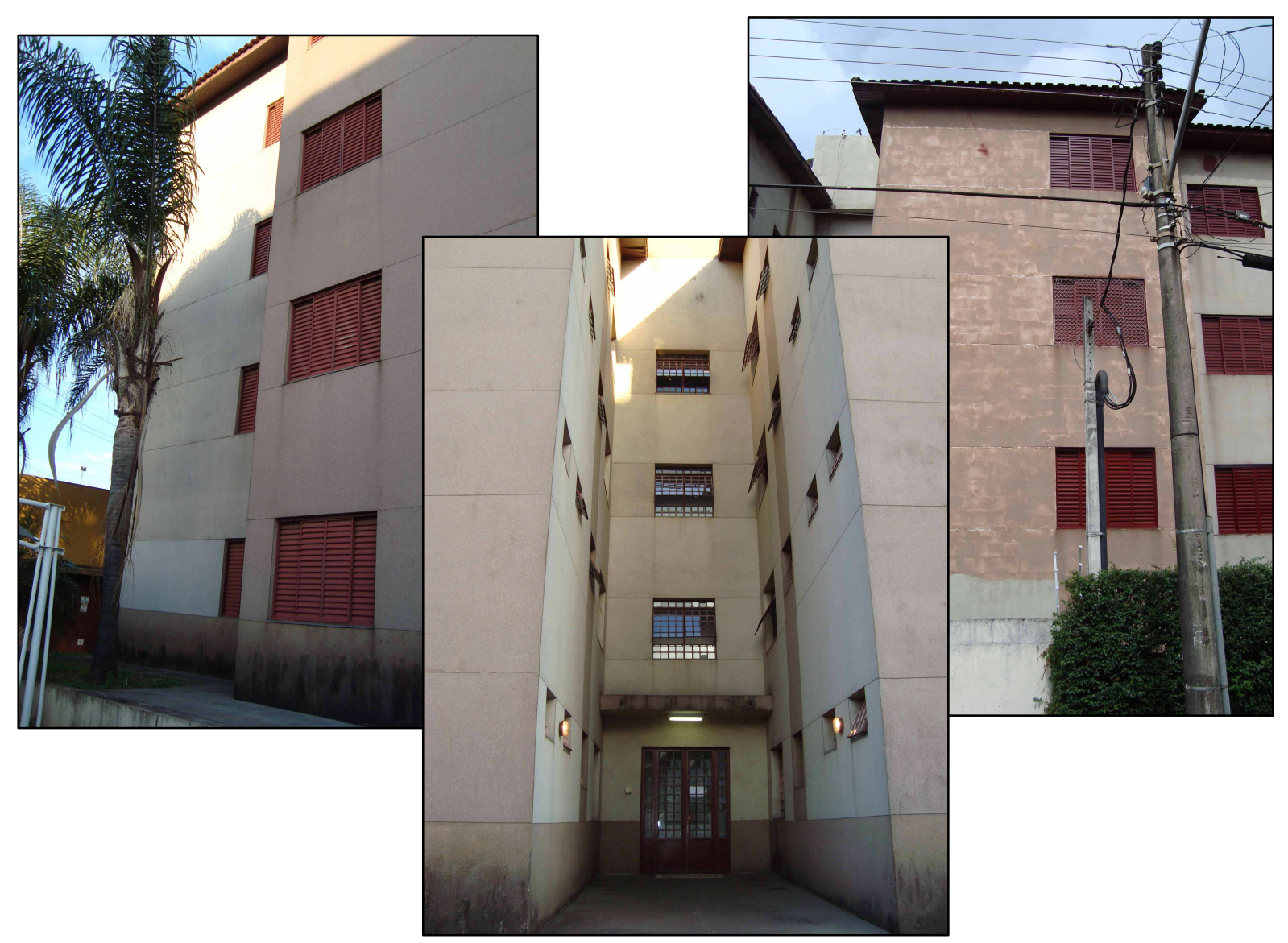

Figura 3.1 - Fachadas frontal e laterais do Edifício A

O primeiro edifício analisado é um edifício residencial em alvenaria estrutural, com o pavimento térreo mais três andares, localizado à Rua Dr. Viriato Fernandes Nunes, n 30, Bairro Jardim Santa Paula, São Carlos/SP. 
Poucas foram as fissuras encontradas na parte externa do edifício, no entanto muitas foram encontradas na parte interna, principalmente em aberturas de portas e janelas.
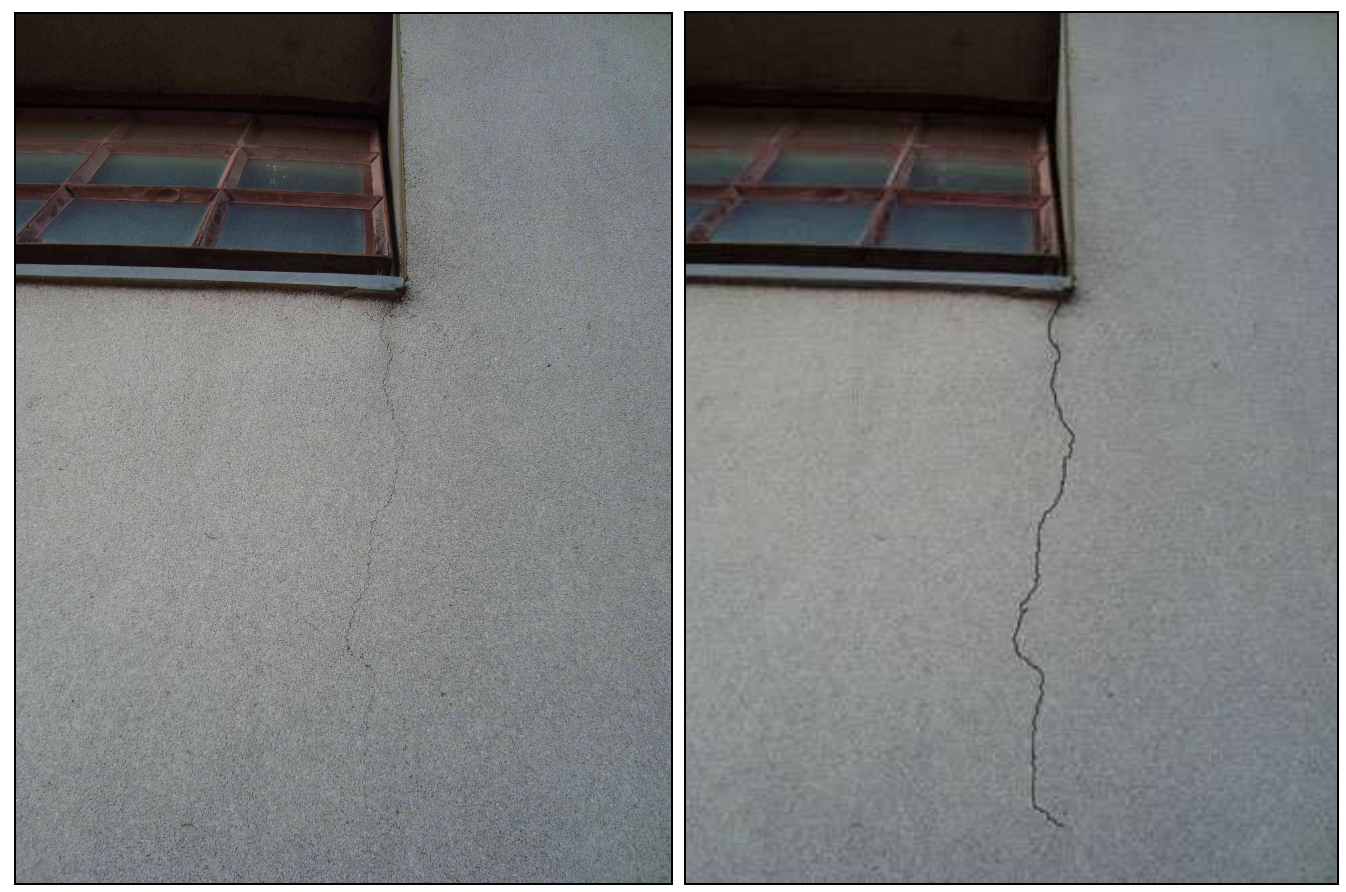

Figura 3.2 - Fissura em canto inferior de abertura de janela em parede externa.

A Figura 3.2 mostra uma fissura vertical com origem no canto inferior de uma janela encontrada na parte externa do edifício. É uma configuração que pode ser considerada típica para fissuras em cantos.

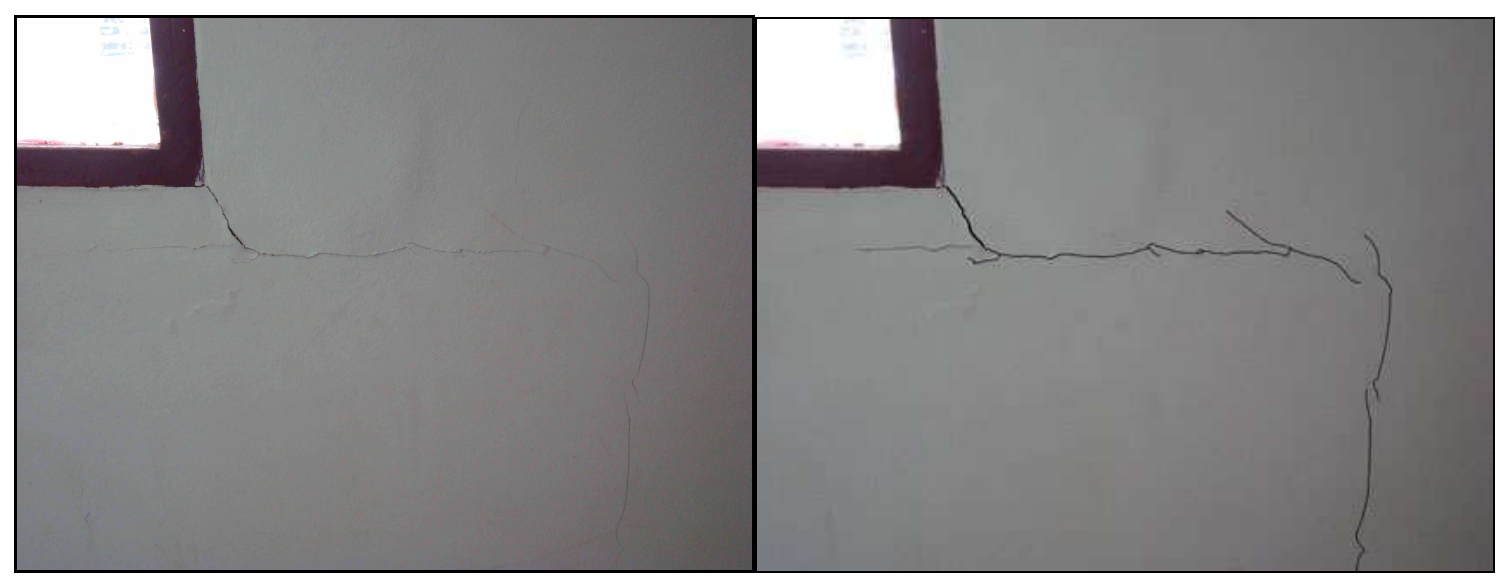

Figura 3.3 - Fissura em canto inferior de abertura de janela em parede interna. 

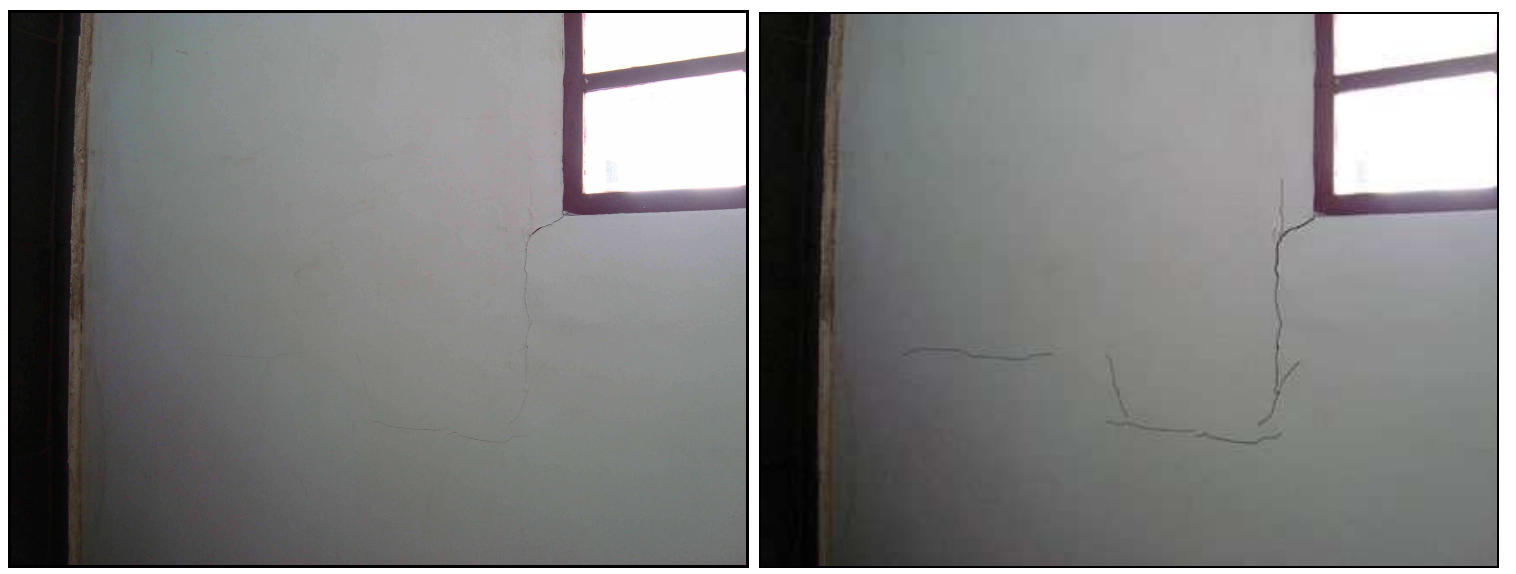

Figura 3.4 - Fissuras em cantos inferiores de aberturas de janelas.

Conforme pode ser observado nas Figuras 3.3 e 3.4 foram encontradas fissuras em cantos de aberturas de janelas de paredes internas, diferentes da encontrada na parede externa. Nesses casos, são fissuras que aparentemente percorrem as juntas de argamassa de assentamento, o que realmente é mais comum em patologias desse tipo.

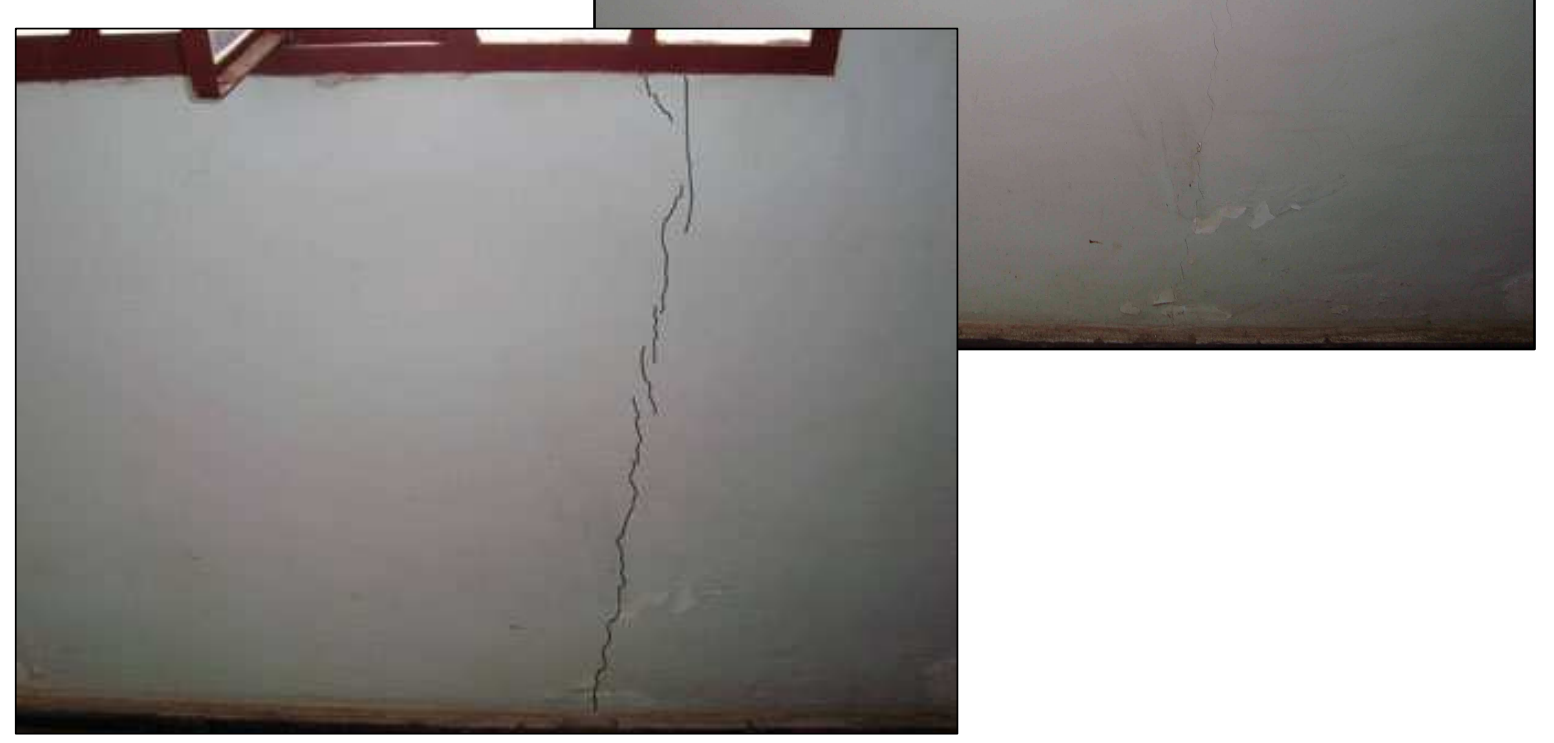

Figura 3.5 - Fissura vertical na parte inferior da abertura de uma janela. 
Capítulo 03 - Fissuras Observadas em Edifícios Residenciais

Na Figura 3.5, observa-se a ocorrência de uma fissura vertical logo abaixo do peitoril de uma janela que se estende até o piso.
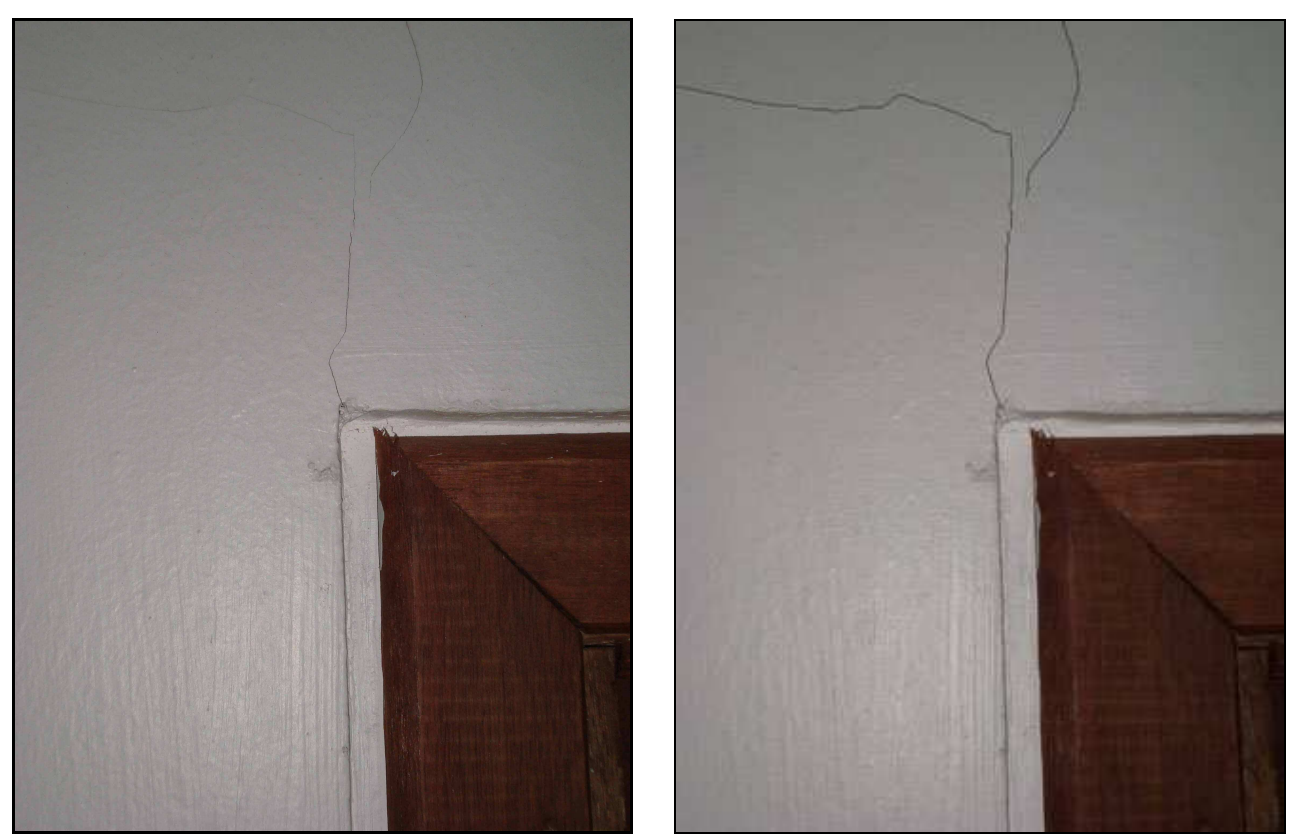

Figura 3.6 - Fissura no canto superior de uma abertura de porta.

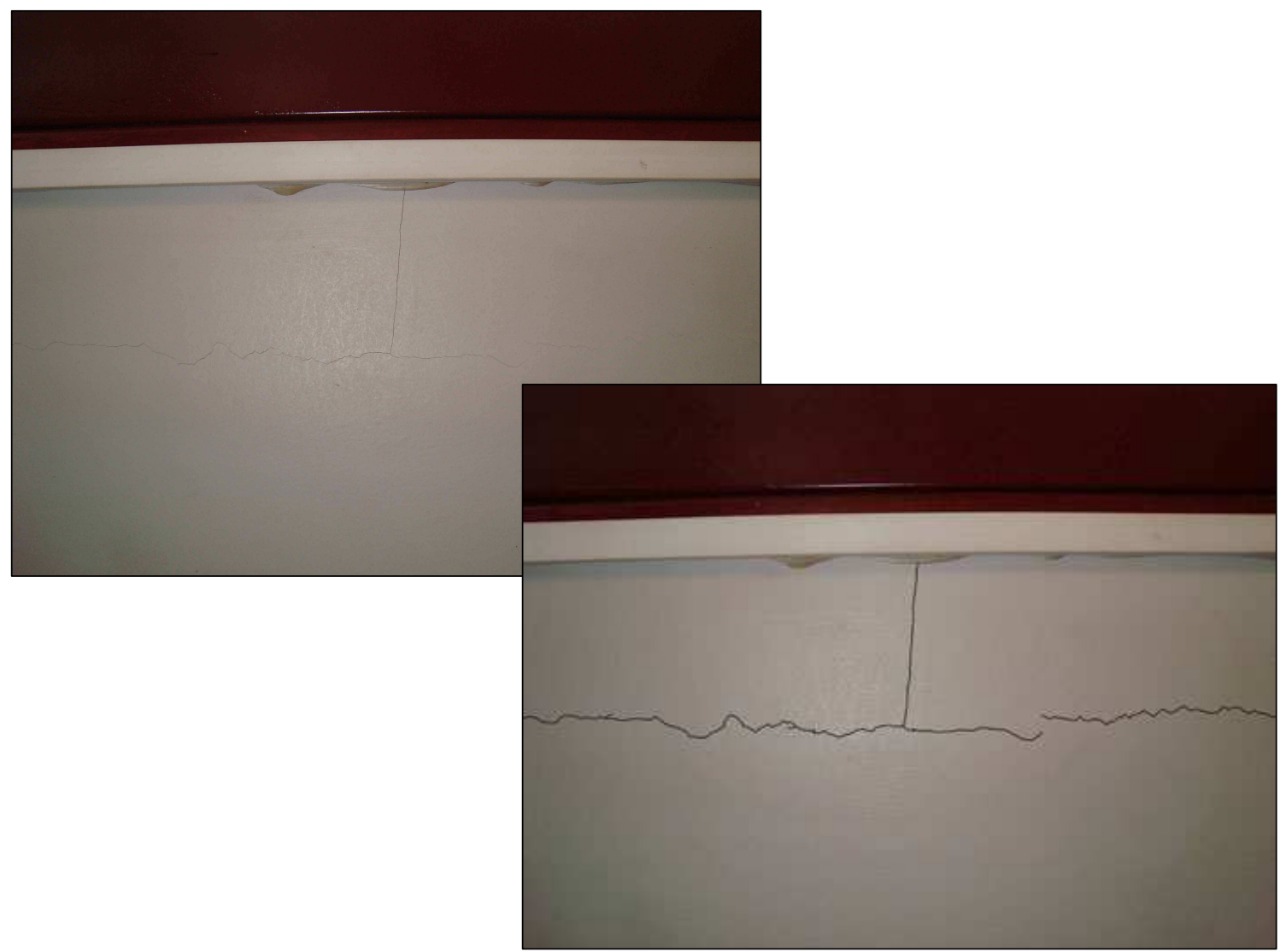

Figura 3.7 - Fissura na parte inferior da abertura de uma janela. 
Foram encontradas nesse edifício variações dessas fissuras com origem em vãos de portas e janelas. Na Figura 3.6 observa-se uma fissura vertical no canto superior de uma abertura de porta, na Figura 3.7 tem-se uma fissura predominantemente horizontal abaixo do peitoril e na Figura 3.8 tem-se uma fissura horizontal na lateral da abertura de uma porta.
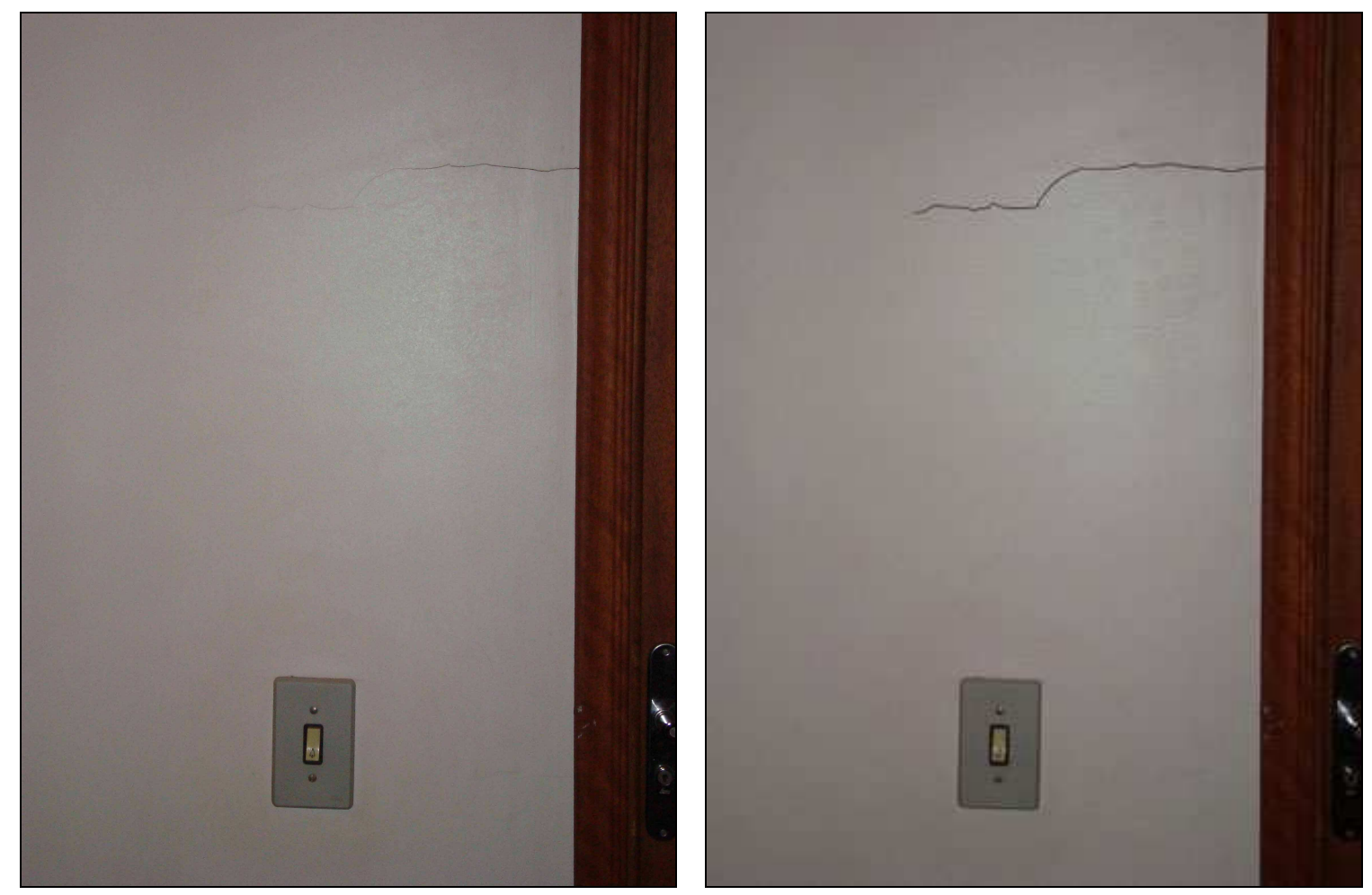

Figura 3.8 - Fissura horizontal na lateral de vão de porta.

Além das fissuras em paredes com abertura de vão foram encontradas fissuras no encontro de paredes com lajes, conforme a Figura 3.9.

Essas fissuras não são comuns a todos os andares e foram encontradas somente em um dos blocos, no pavimento térreo. 


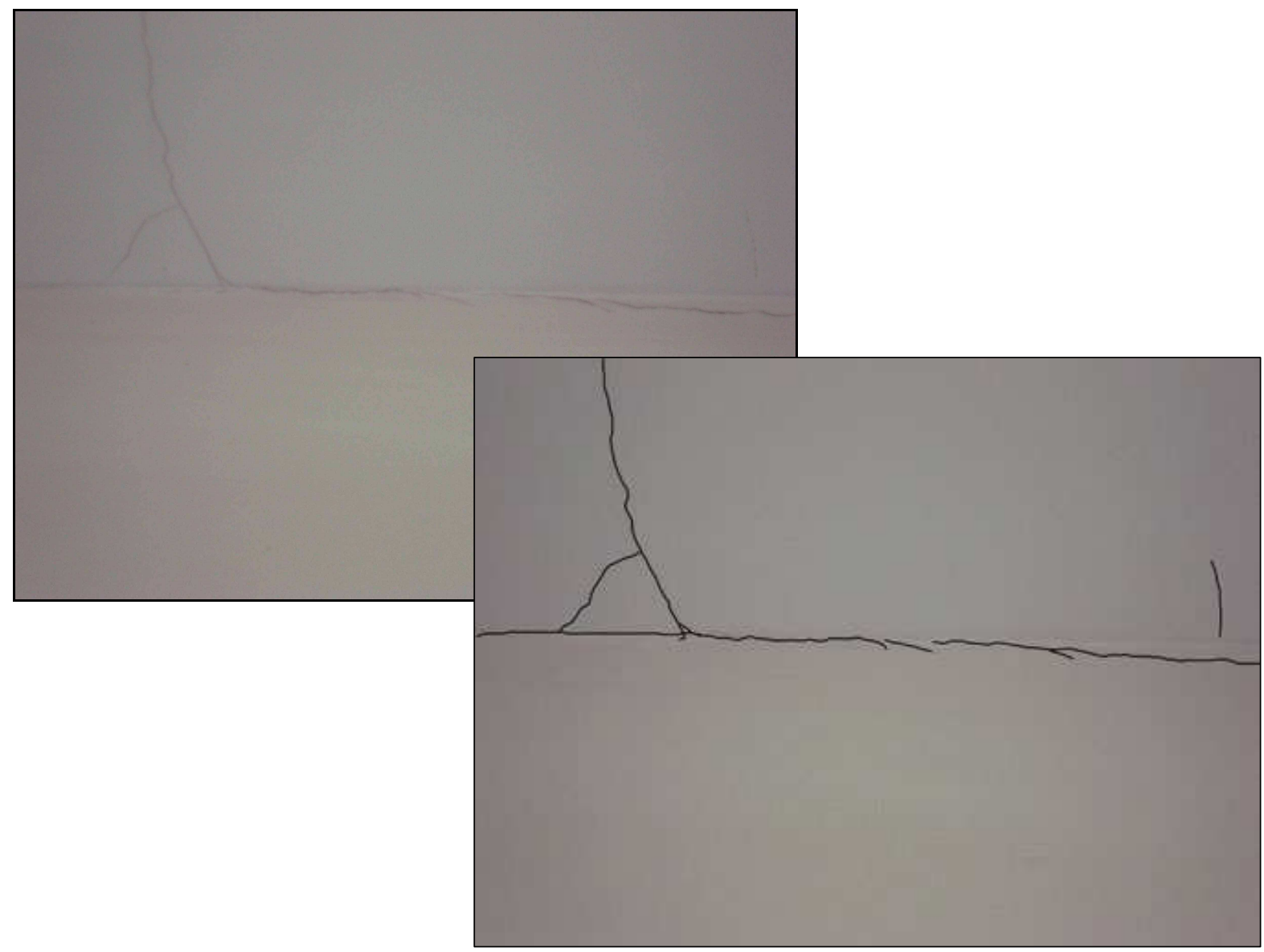

Figura 3.9 - Fissuras no encontro de paredes com lajes.

\subsubsection{Edifício B}

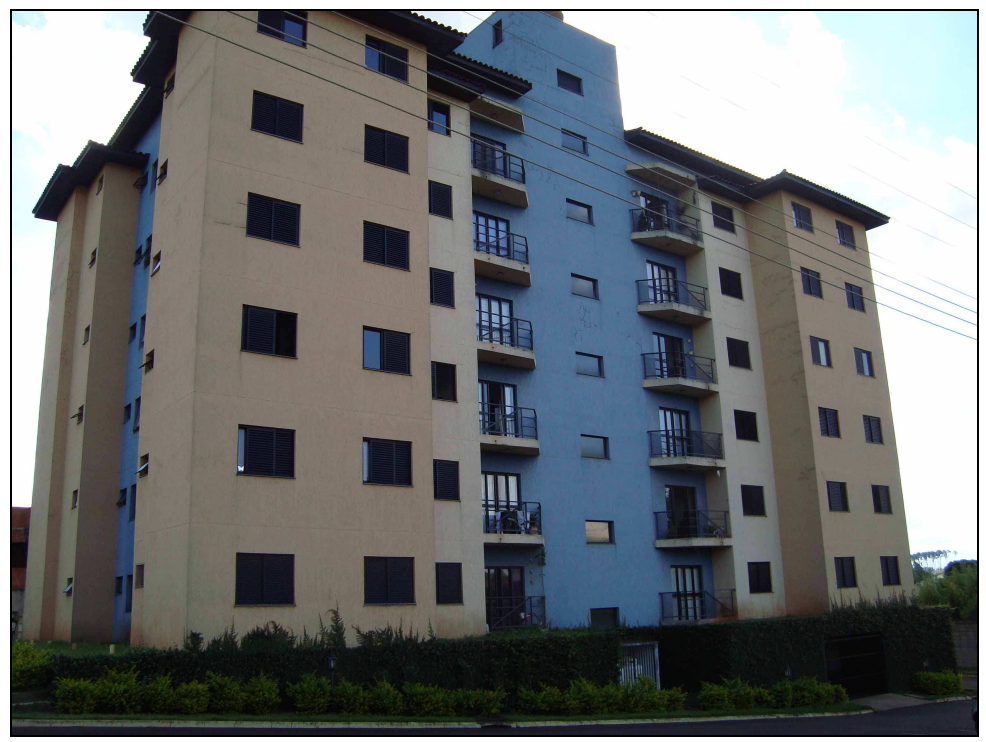

Figura 3.10 - Fachada frontal do Edifício B. 
A segunda análise foi realizada num edifício residencial em alvenaria estrutural, com o pavimento térreo mais seis andares, localizado à Avenida Comendador Alfredo Maffei, nº 250, Bairro Jardim Brasil, São Carlos/SP.

Esse edifício foi analisado apenas externamente, porém foram encontrados vários tipos de fissuras: em cantos de aberturas de portas e janelas; horizontais na altura da laje; horizontais à meia parede; e mapeadas.

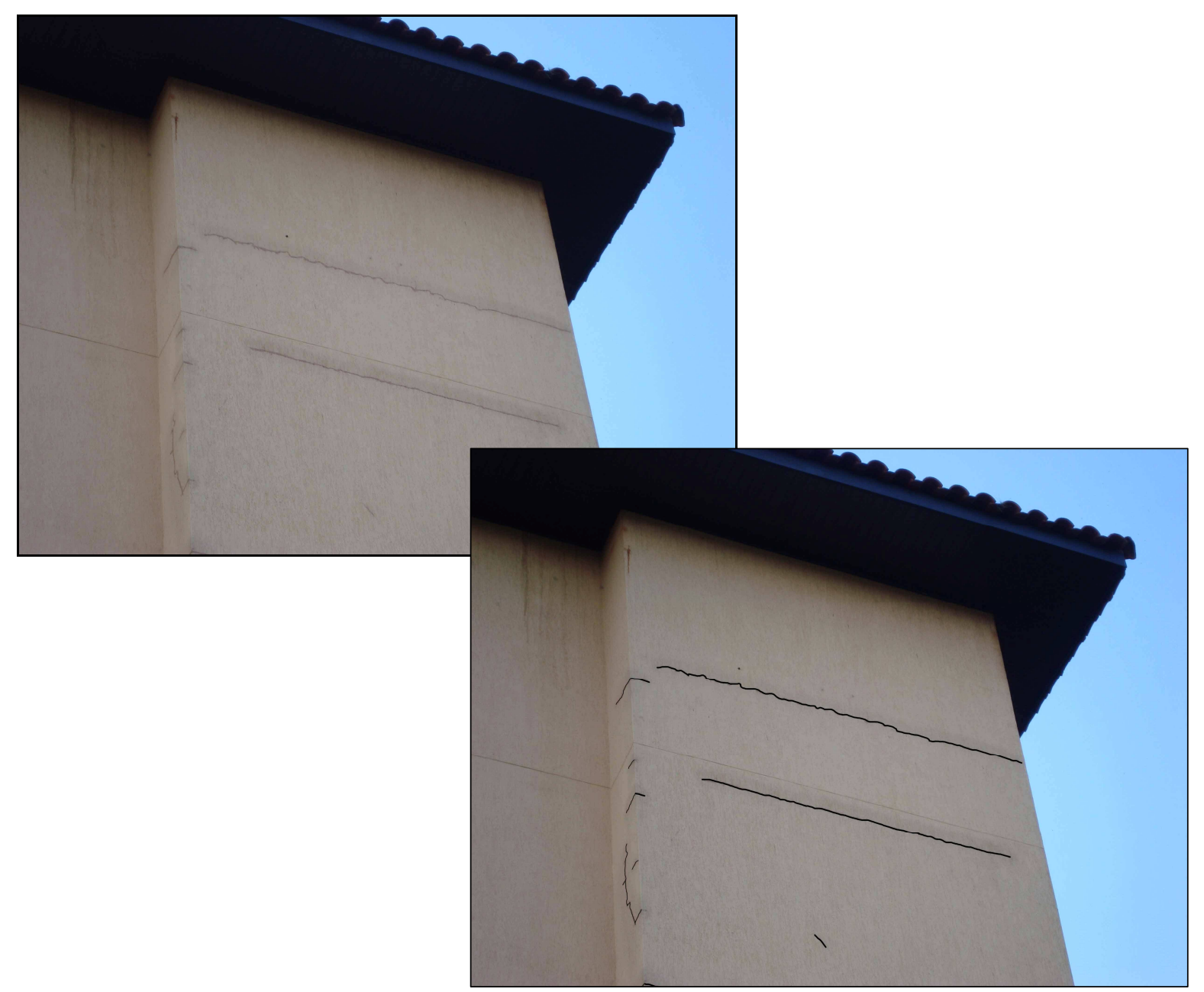

Figura 3.11 - Fissuras horizontais na altura da laje e à meia altura da parede.

Nesse edifício encontram-se alguns exemplos de fissuras horizontais ao longo da altura da laje assim como à meia altura da parede. Esses tipos ocorreram várias vezes inclusive numa mesma parede, conforme mostram as Figuras 3.11 e 3.12. 


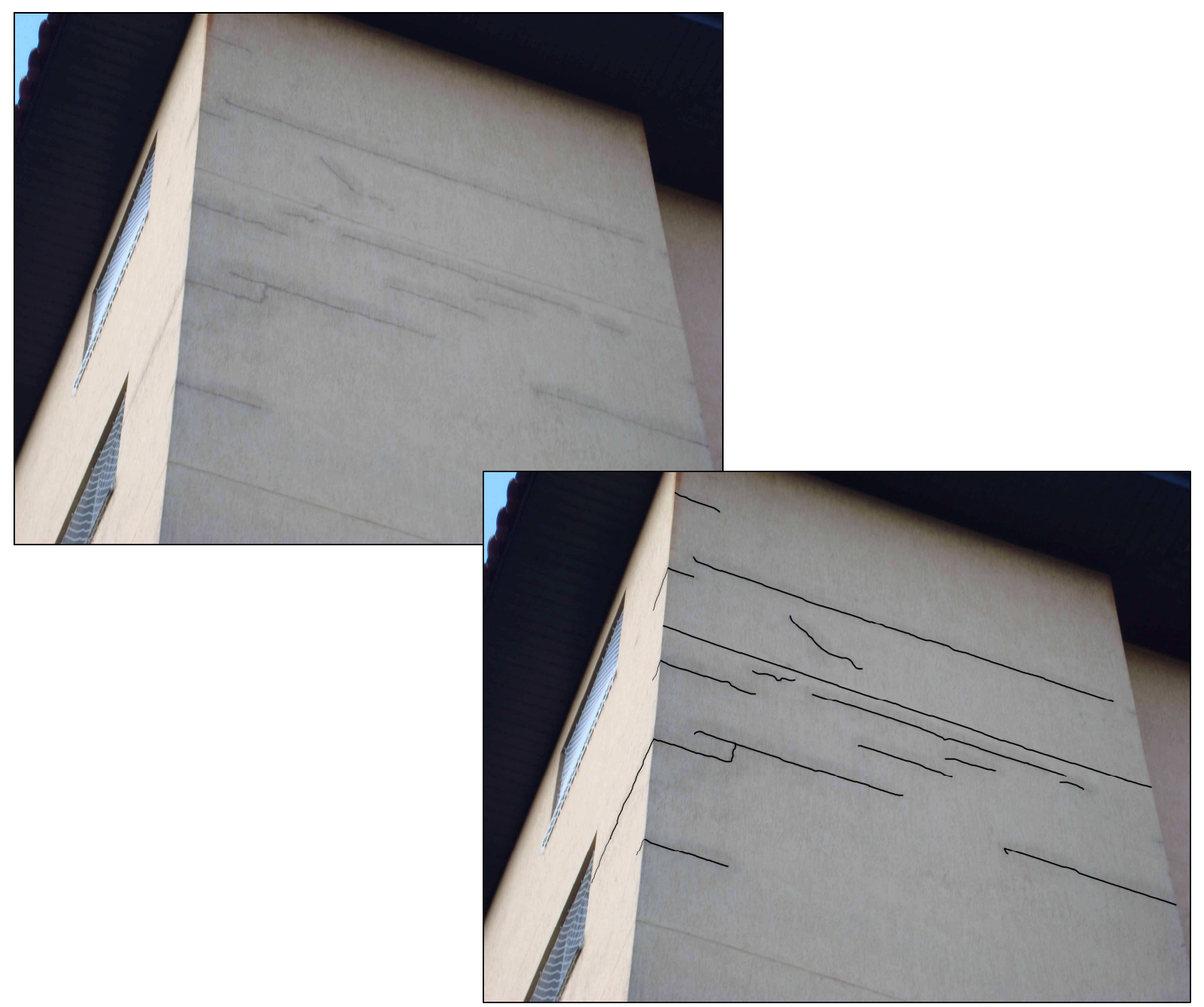

Figura 3.12 - Fissuras horizontais na altura da laje e à meia altura da parede.

Na Figura 3.13 têm-se algumas das fissuras encontradas em cantos de aberturas de vãos de portas e janelas, Nesses casos, nota-se que as fissuras possuem configurações verticais e/ou inclinadas. 

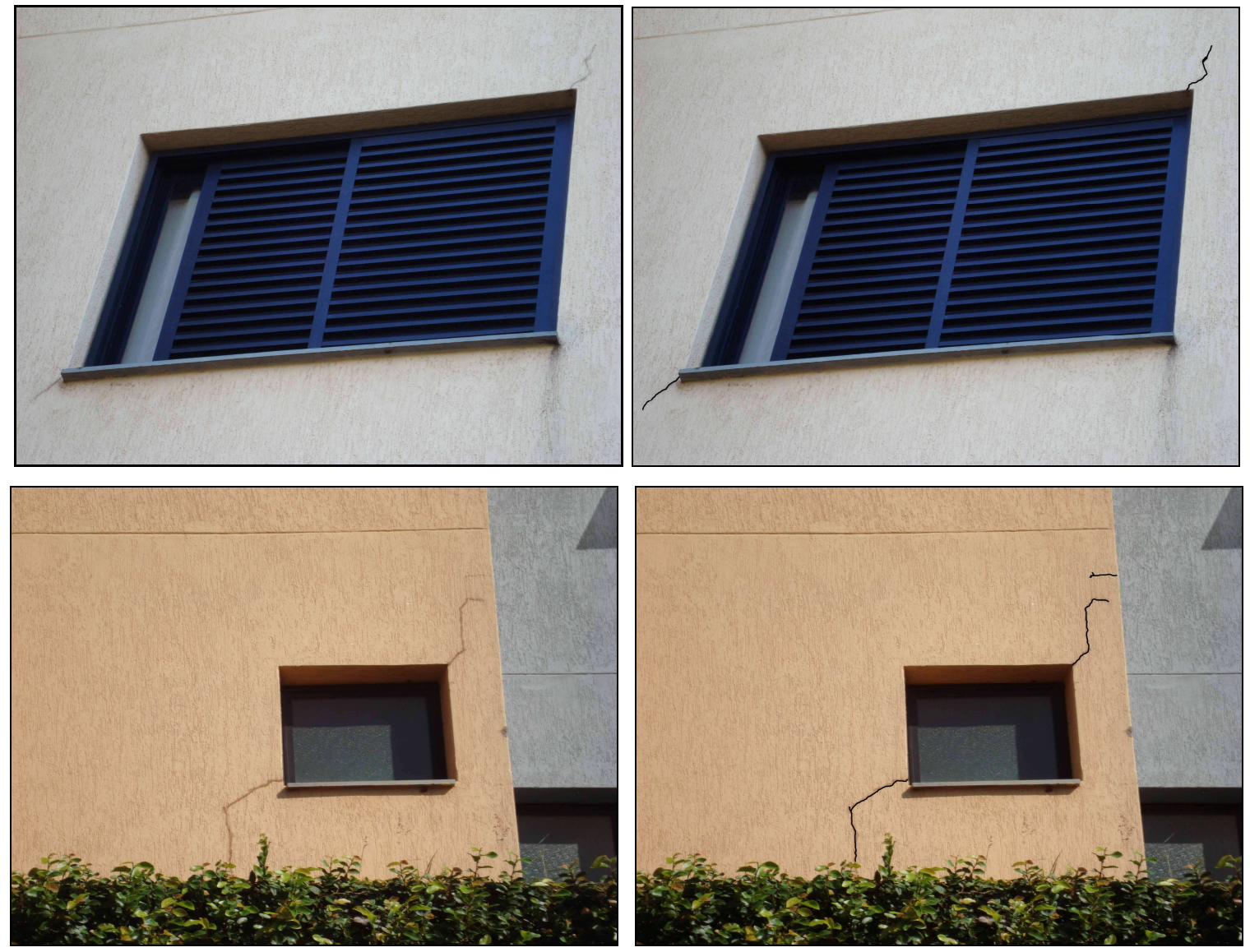

Figura 3.13 - Fissuras em cantos de aberturas de janelas.

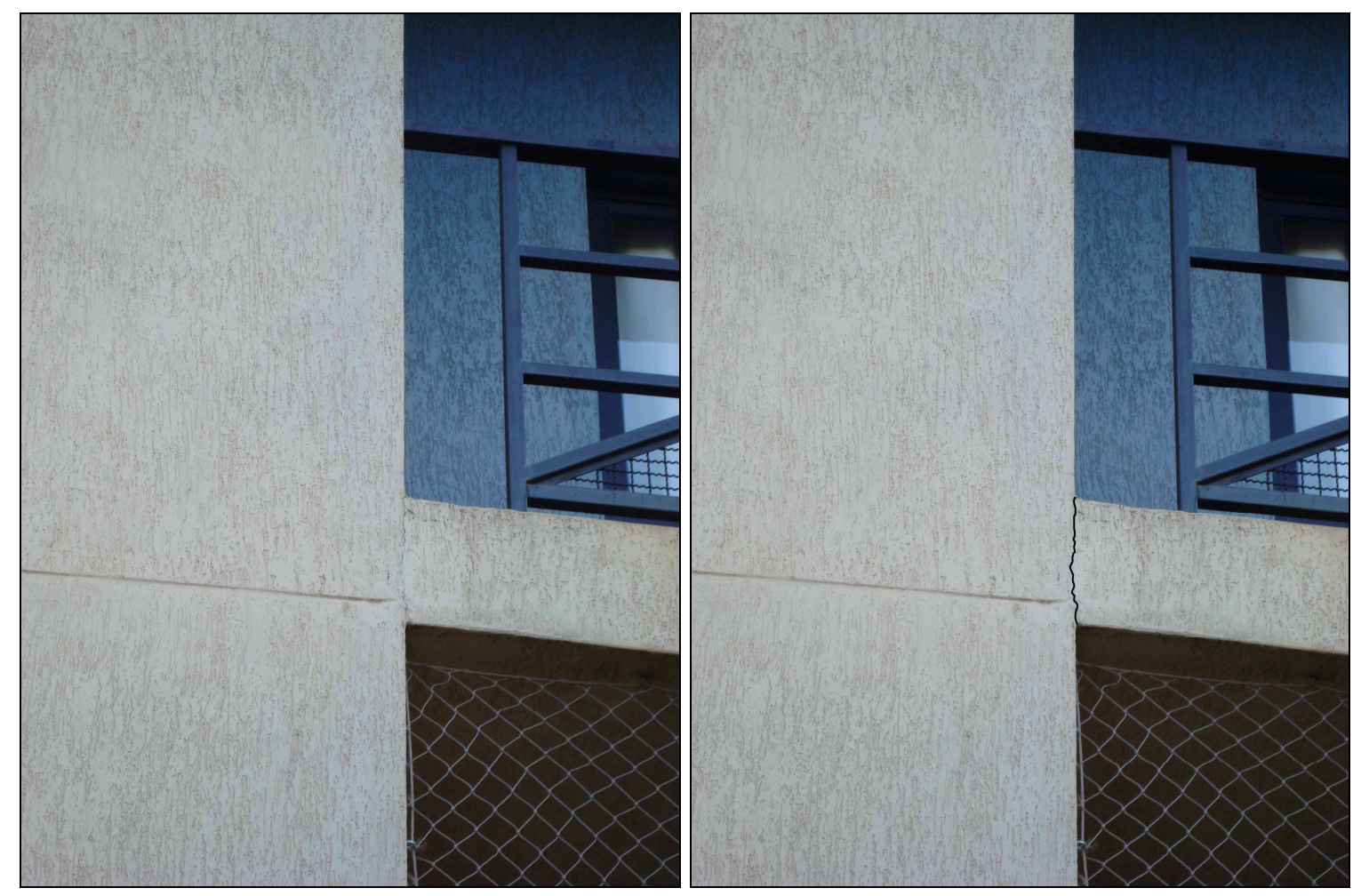

Figura 3.14 - Fissura vertical em encontro de laje de piso e parede. 
A Figura 3.14 mostra um tipo de fissura que foi comum apenas ao edifício E. Ela possui formato vertical e localiza-se no encontro entre a laje de piso de uma sacada e uma parede em alvenaria estrutural.

A fissura da Figura 3.15 possui um formato vertical e ocorre numa parede de alvenaria que está recebendo o carregamento de uma laje de sacada. Essa fissura não é comum a nenhum outro edifício.
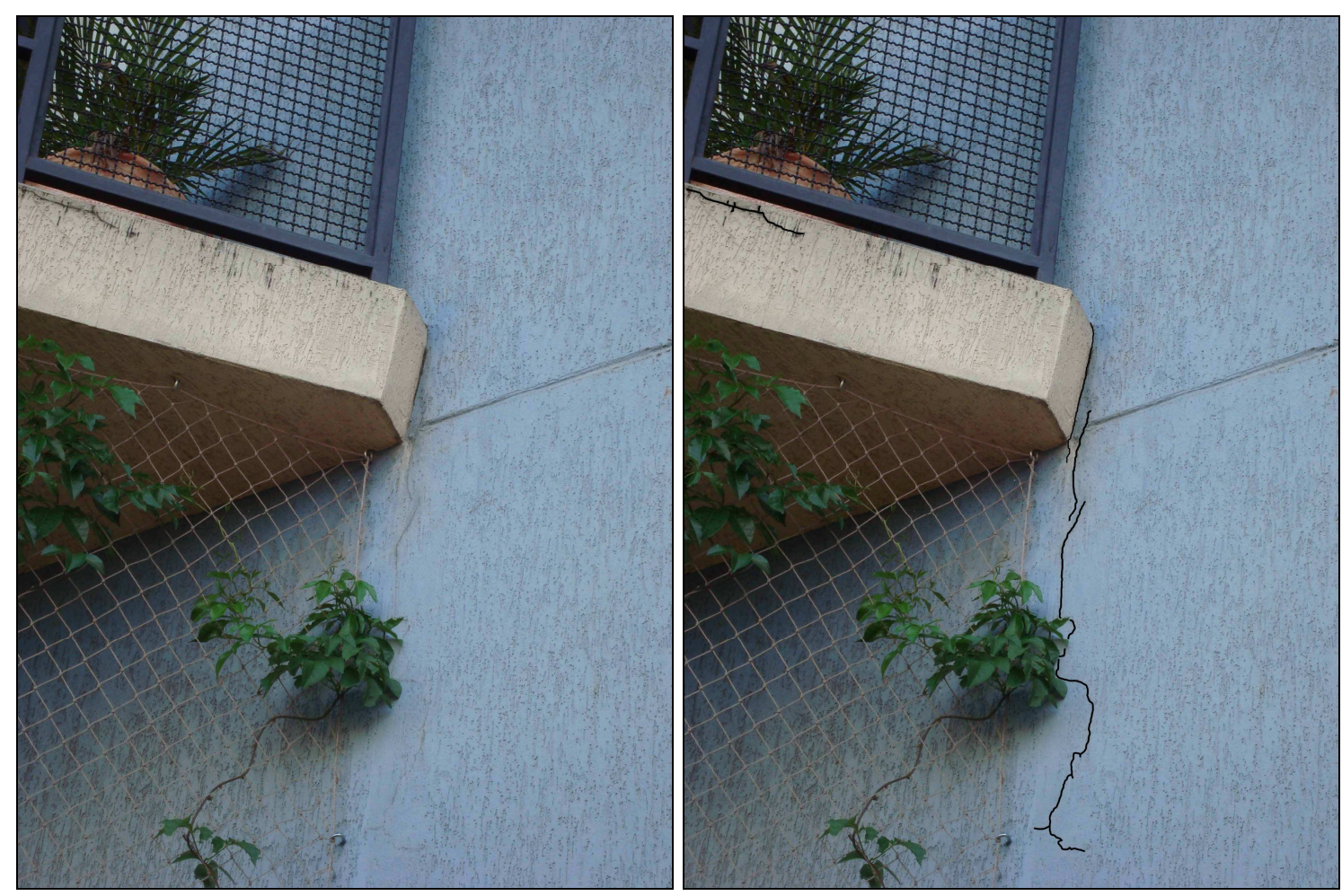

Figura 3.15 - Fissura causada pelo carregamento de uma laje de sacada.
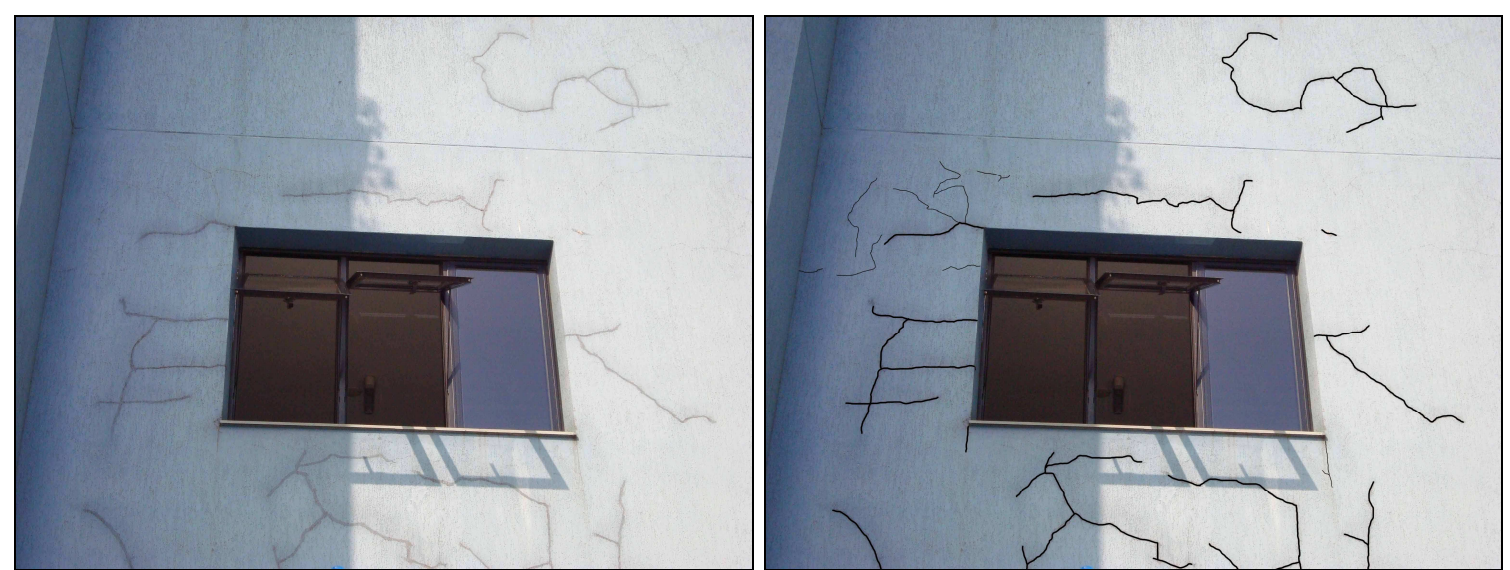

Figura 3.16 - Fissuras mapeadas. 
As fissuras da Figura 3.16 ocorrem ao redor de toda a abertura e se apresentam de diversas maneiras, isso por se desenvolverem apenas na argamassa de revestimento.

\subsubsection{Edifício C}

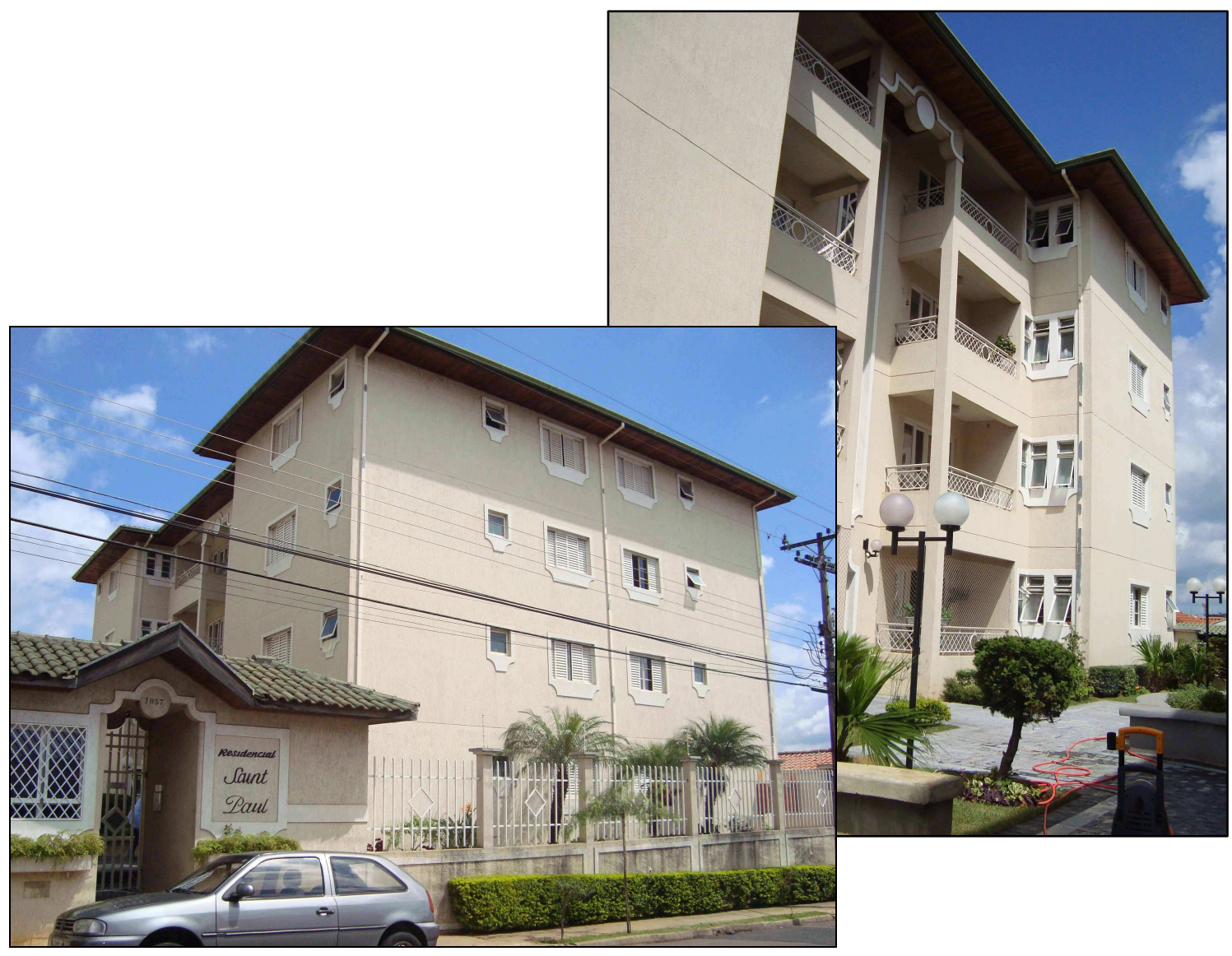

Figura 3.17 - Fachadas frontal e lateral do Edifício C.

A terceira análise foi realizada num edifício residencial em alvenaria estrutural, com o pavimento térreo mais três andares, localizado à Rua Paulino Botelho de Abreu Sampaio, nº 1057, Bairro Centro, São Carlos/SP.

Neste edifício foram encontrados alguns tipos de fissuras, tais como: em cantos de vãos de portas e janelas; e fissuras horizontais na base da parede de alvenaria. 

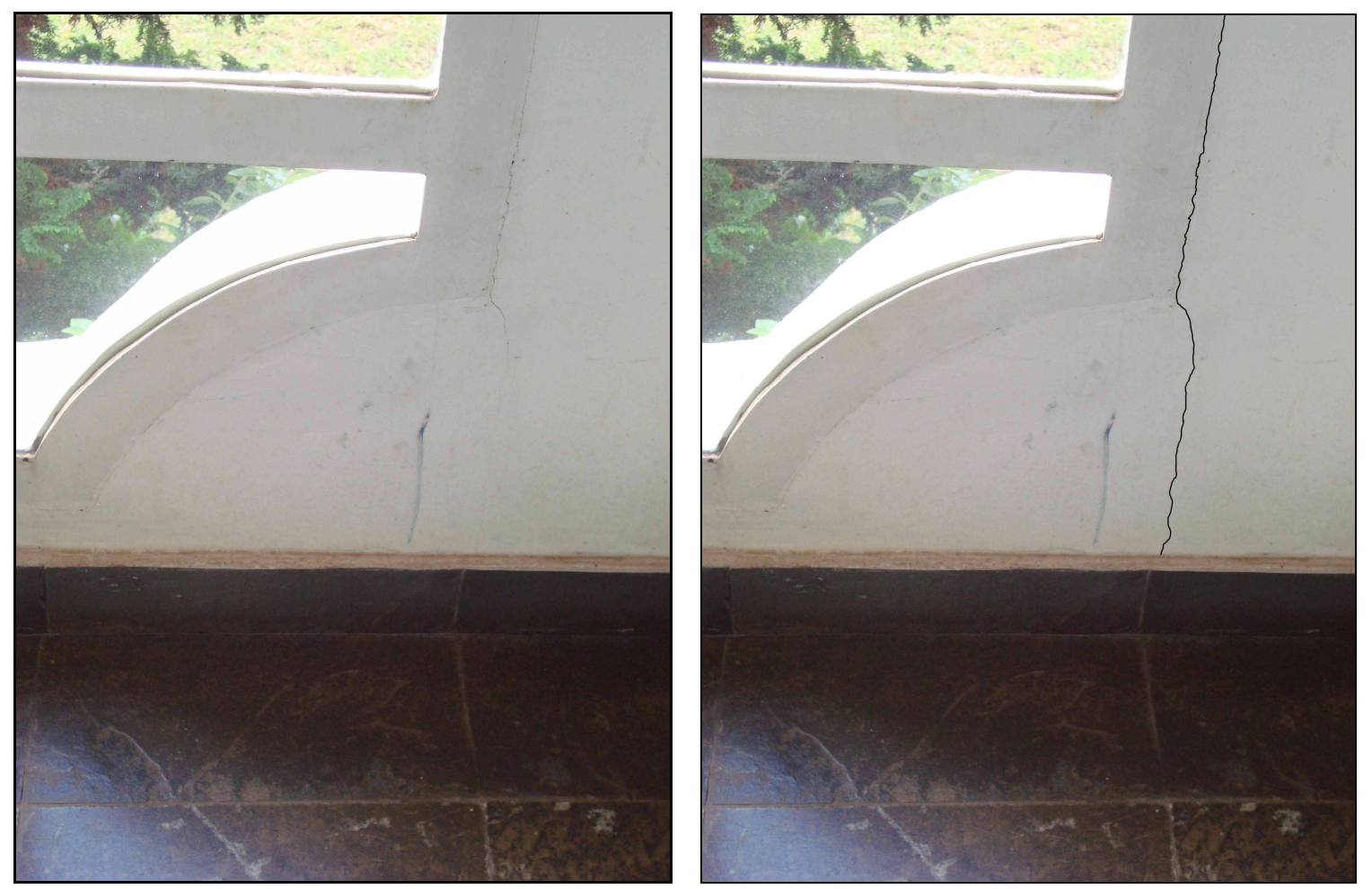

Figura 3.18 - Fissuras internas em cantos inferiores de aberturas de janelas.
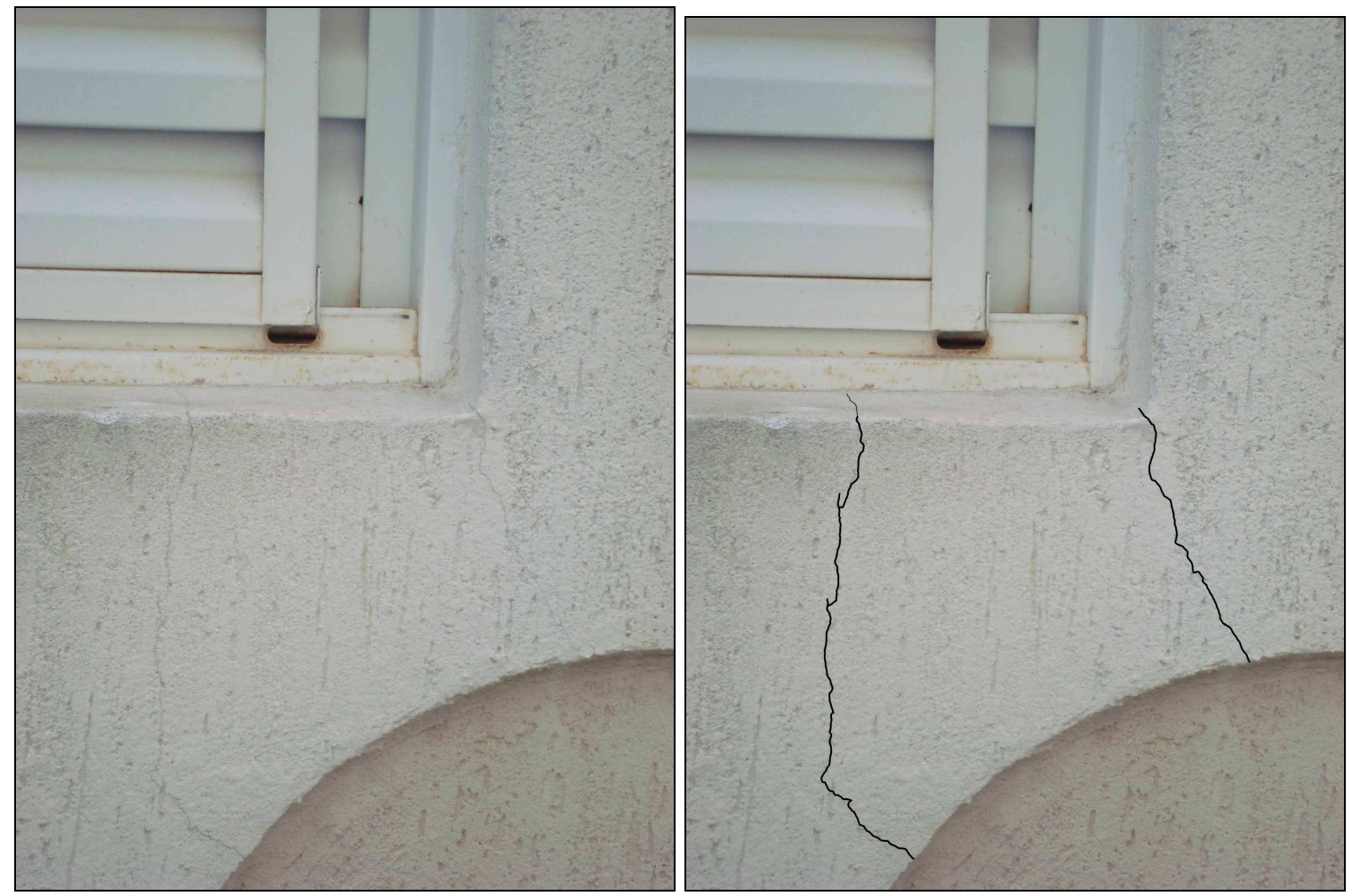

Figura 3.19 - Fissuras externas em cantos inferiores de aberturas de janelas.

As fissuras mostradas nas Figuras 3.18 e 3.19 ocorreram em cantos de aberturas de janelas interna e externa, respectivamente. 
Fissuras semelhantes a essas ocorreram em vãos de portas, mas principalmente nos cantos inferiores das janelas. Em algumas situações se prolongaram de forma horizontal ou vertical, ou mesmo de forma escalonada como mostra as Figuras 3.20, 3.21 e 3.22, respectivamente.

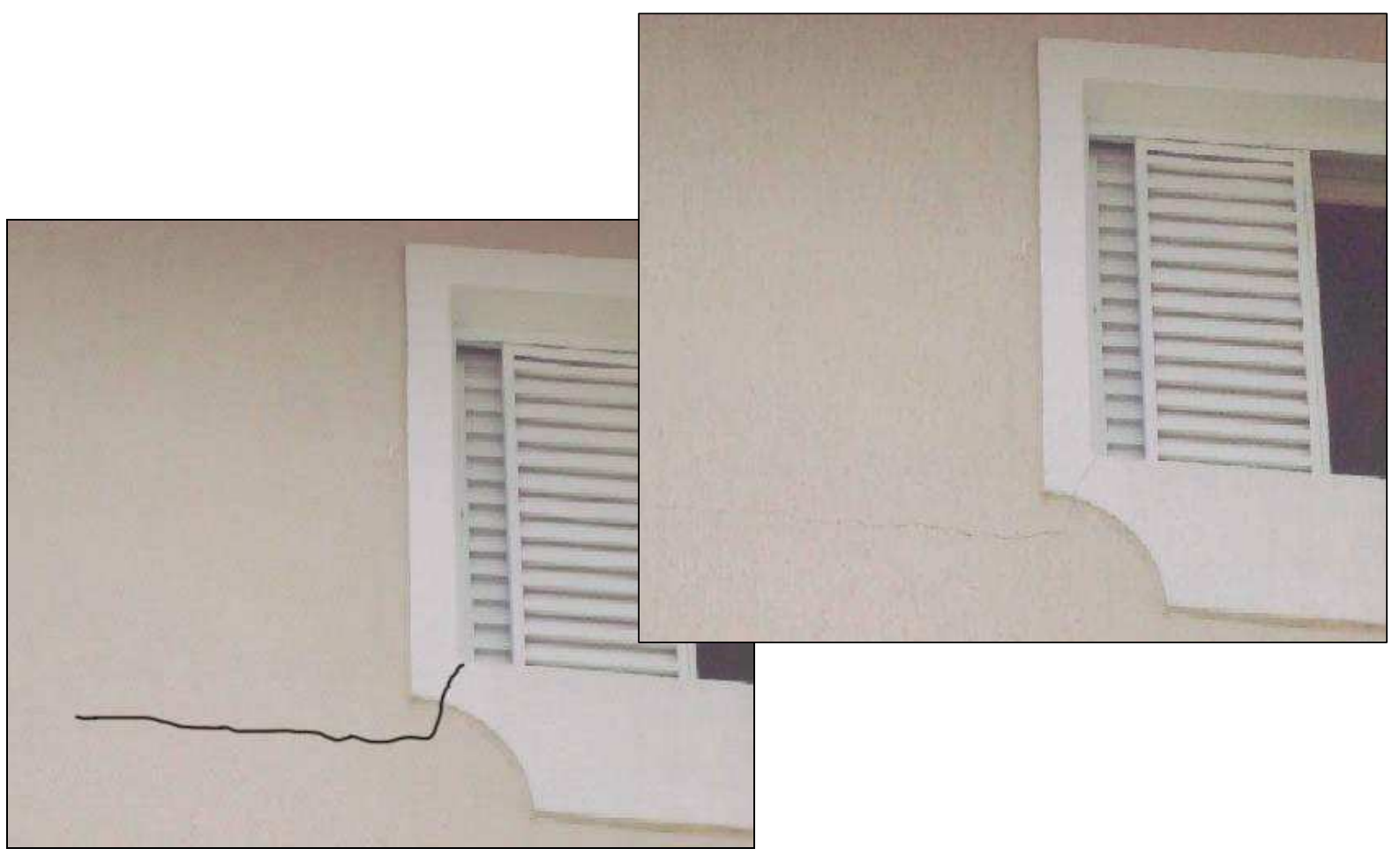

Figura 3.20 - Fissura com formato predominantemente horizontal.
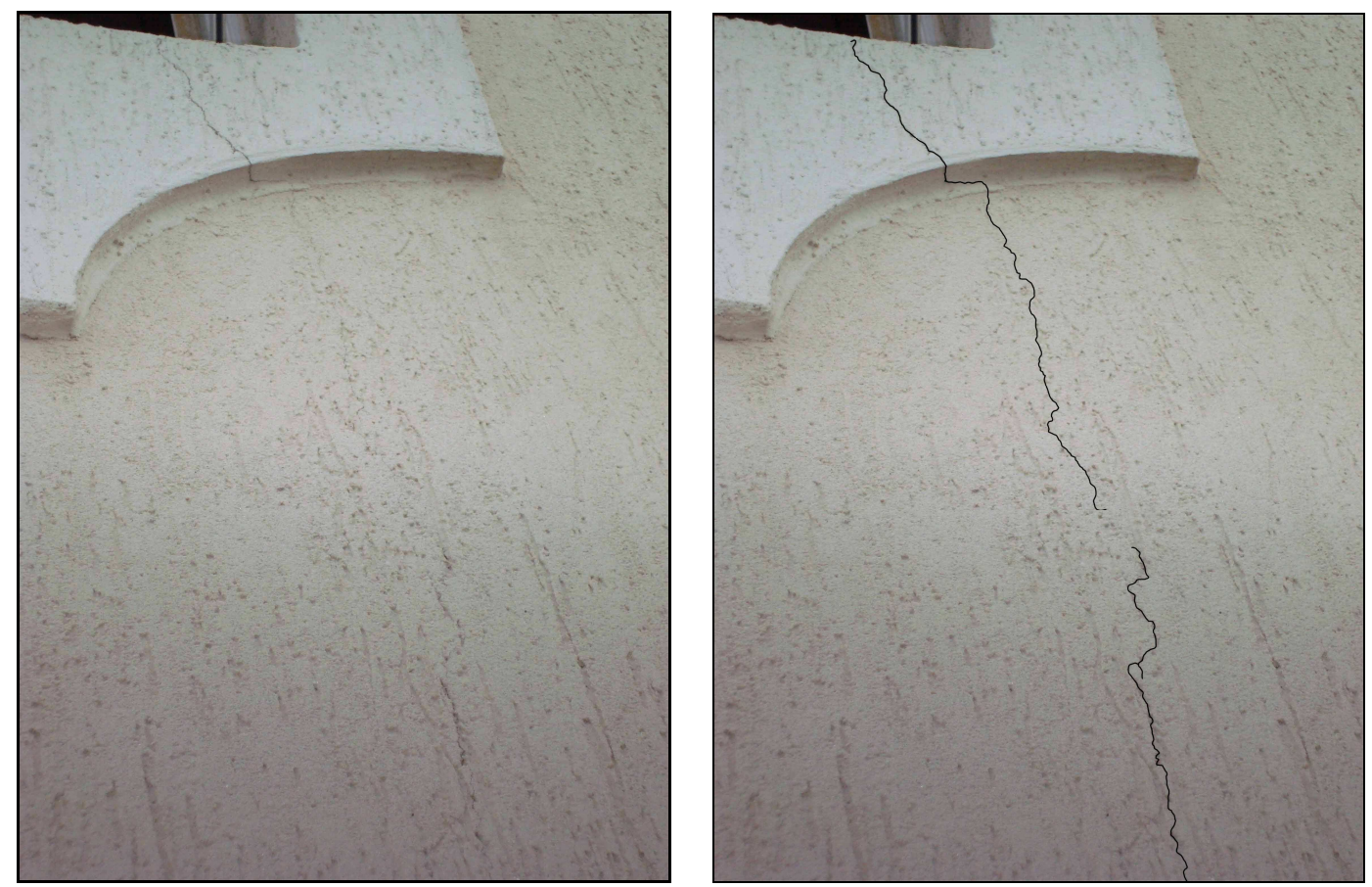

Figura 3.21 - Fissura com formato predominantemente vertical. 


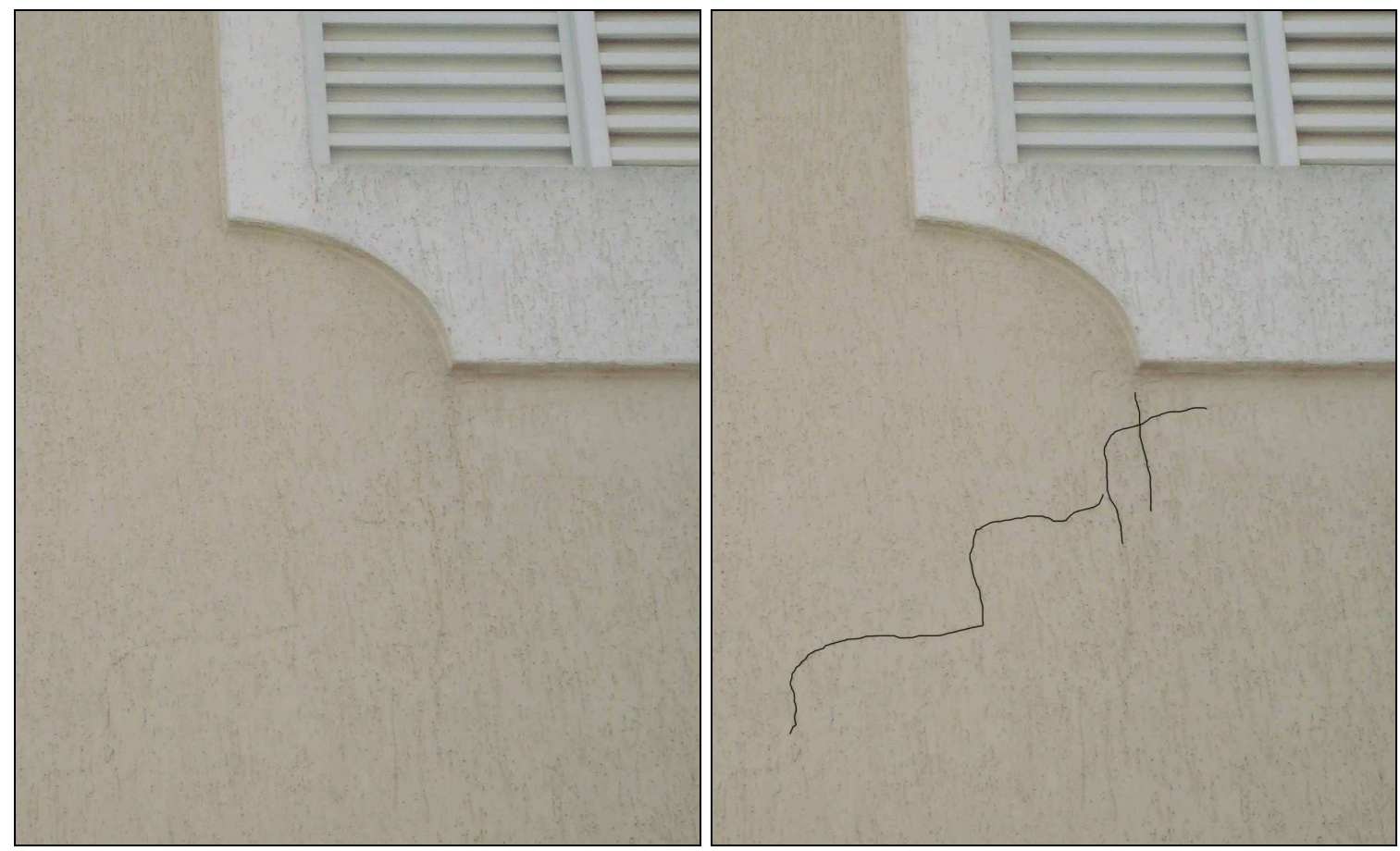

Figura 3.22 - Fissuras em cantos inferiores de aberturas de janelas.

Na Figura 3.23 tem-se uma fissura vertical com origem no canto superior do vão de uma porta.
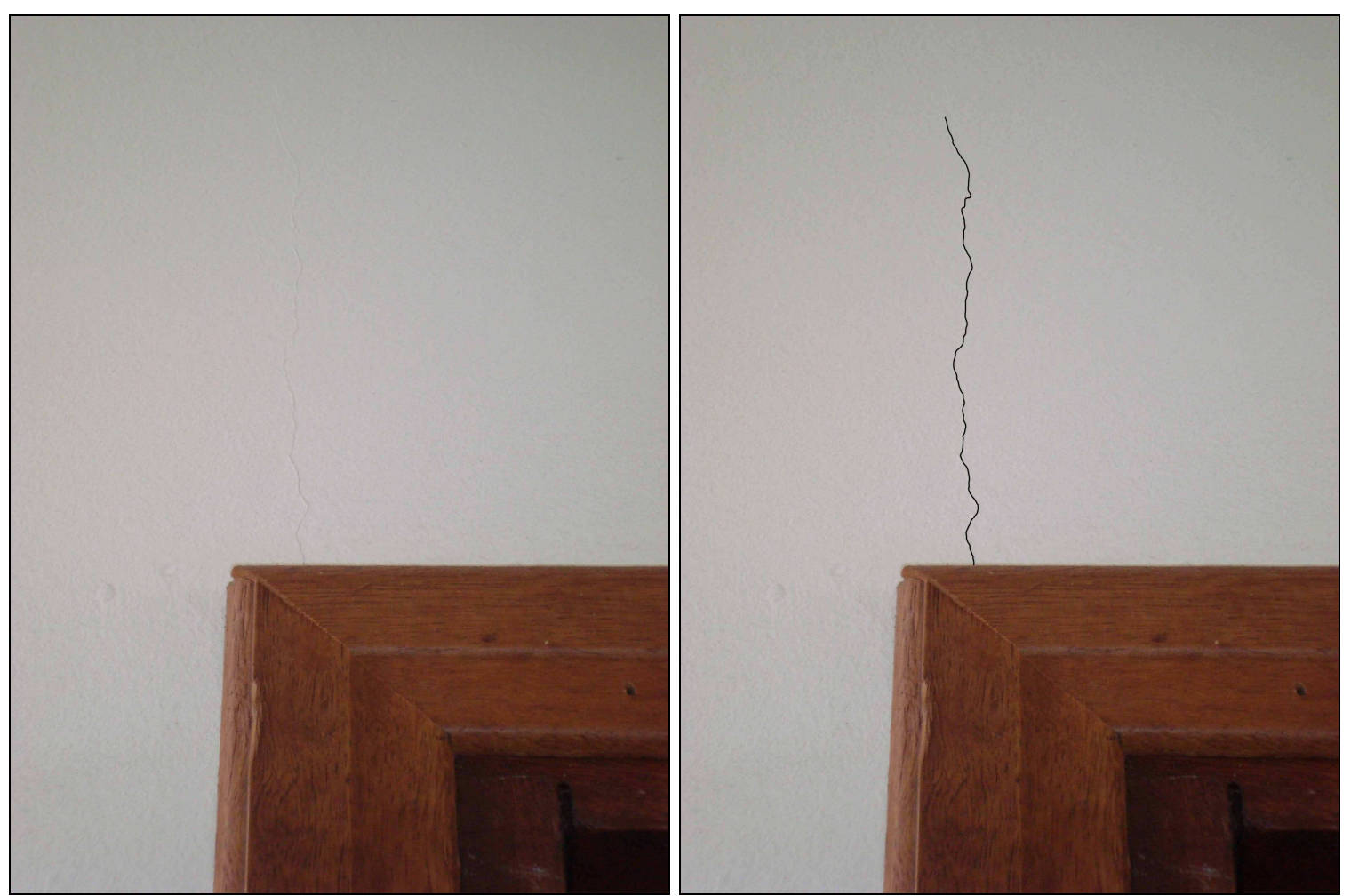

Figura 3.23 - Fissura em canto de abertura de porta. 
Outro tipo de fissura encontrada apenas nesse edifício foram as fissuras horizontais ao longo da base de uma parede externa. Elas atingiram três paredes de um dos blocos do conjunto habitacional permanecendo contínuas inclusive no encontro das paredes, conforme as Figuras 3.24 e 3.25.
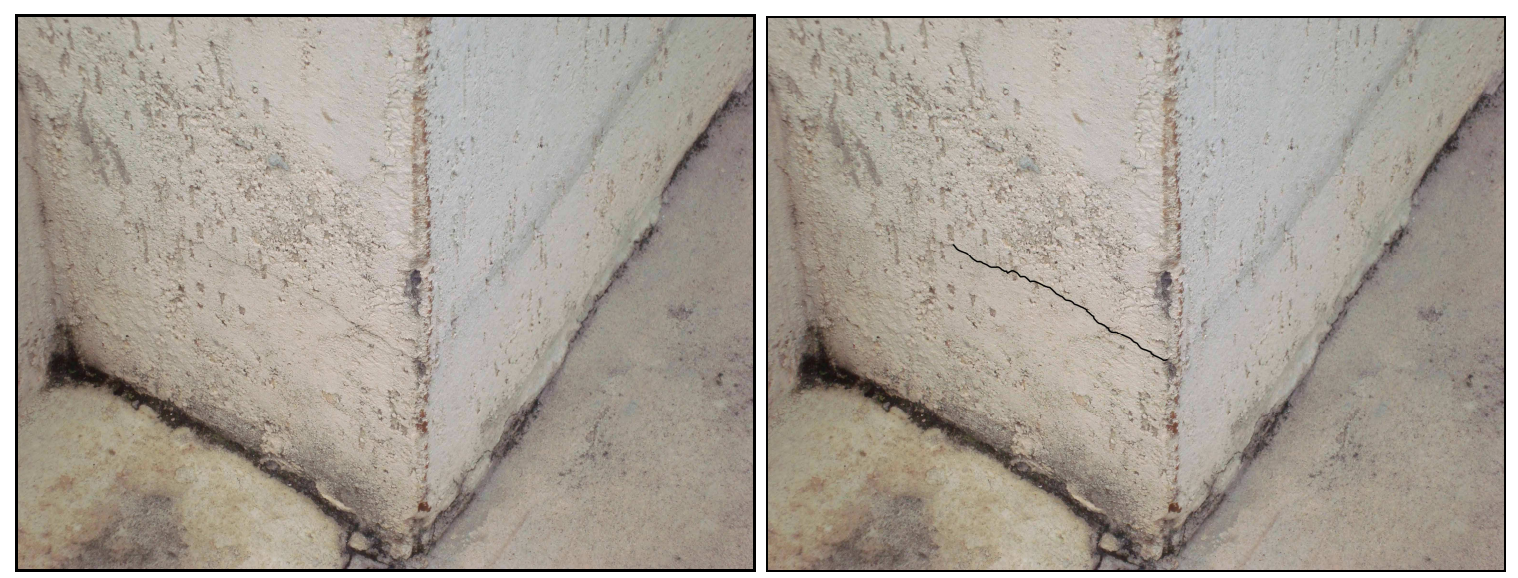

Figura 3.24 - Fissura em encontro de paredes em alvenaria estrutural.
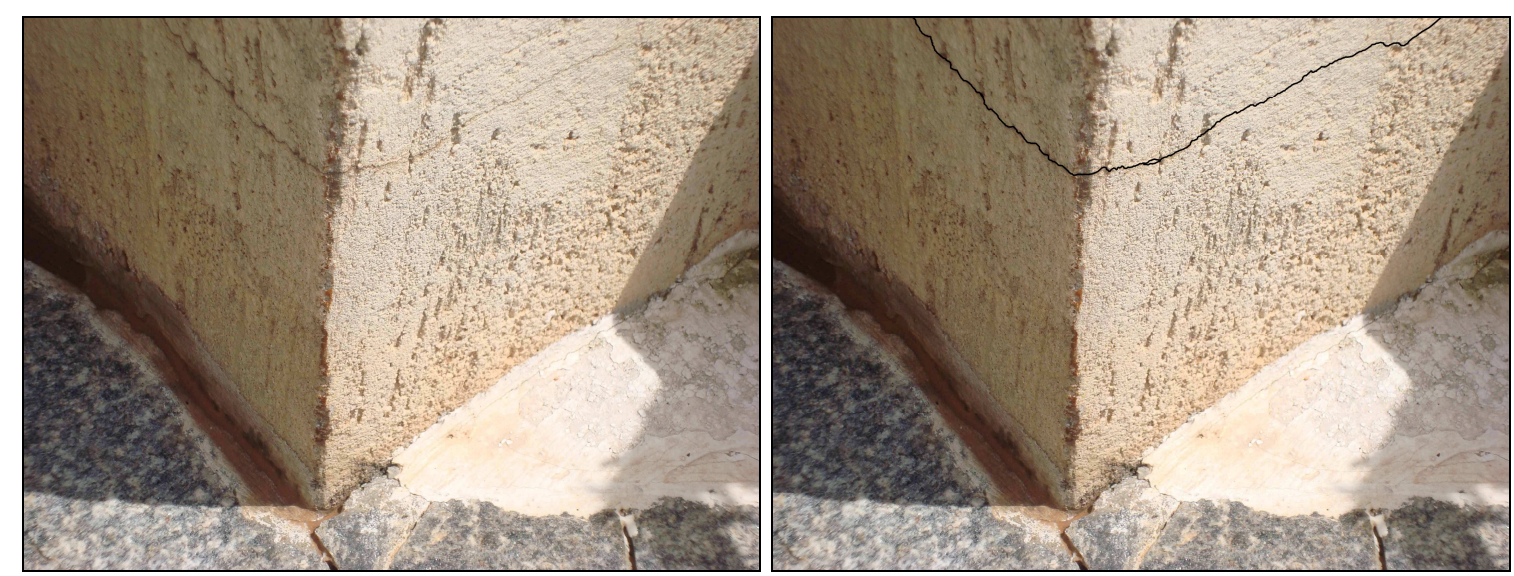

Figura 3.25 - Fissura ao longo da base da parede de alvenaria estrutural. 


\subsubsection{Edifício D}

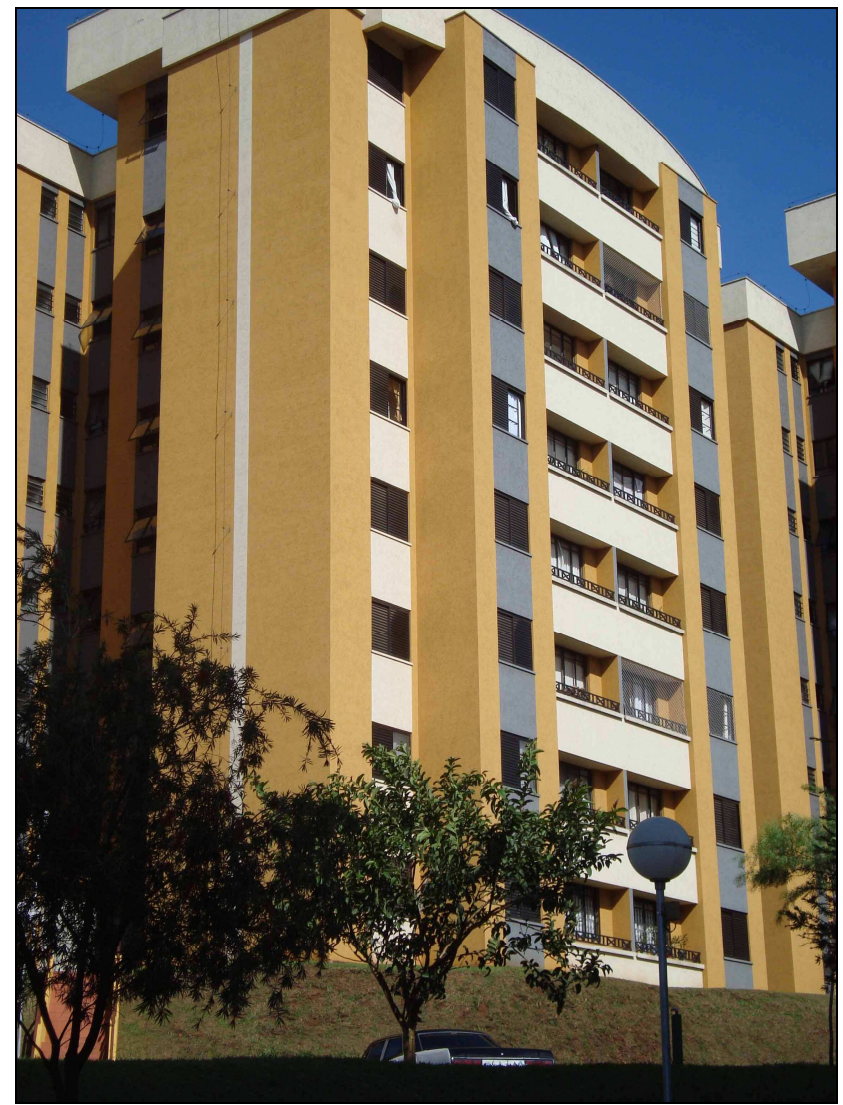

Figura 3.26 - Fachada frontal do Edifício D

A quarta análise foi realizada num edifício residencial em alvenaria estrutural, com o pavimento térreo mais sete andares, localizado Av. Tancredo de Almeida Neves, $\mathrm{n}^{\mathrm{o}}$ 457, Bairro Jardim Gibertoni, São Carlos/SP.

Apesar desse edifício pertencer a um conjunto com vários blocos iguais, a análise foi realizada em apenas um dos blocos onde foram encontradas poucas fissuras.

Foram encontradas fissuras localizadas nos cantos inferiores de vãos de janelas, como mostram as Figuras 3.27 e 3.28 e na parte inferior central do vão, como mostra a Figura 3.29. Esses tipos de fissuras foram comuns a todas as janelas existentes ao longo da parede onde fica localizada a escada. 

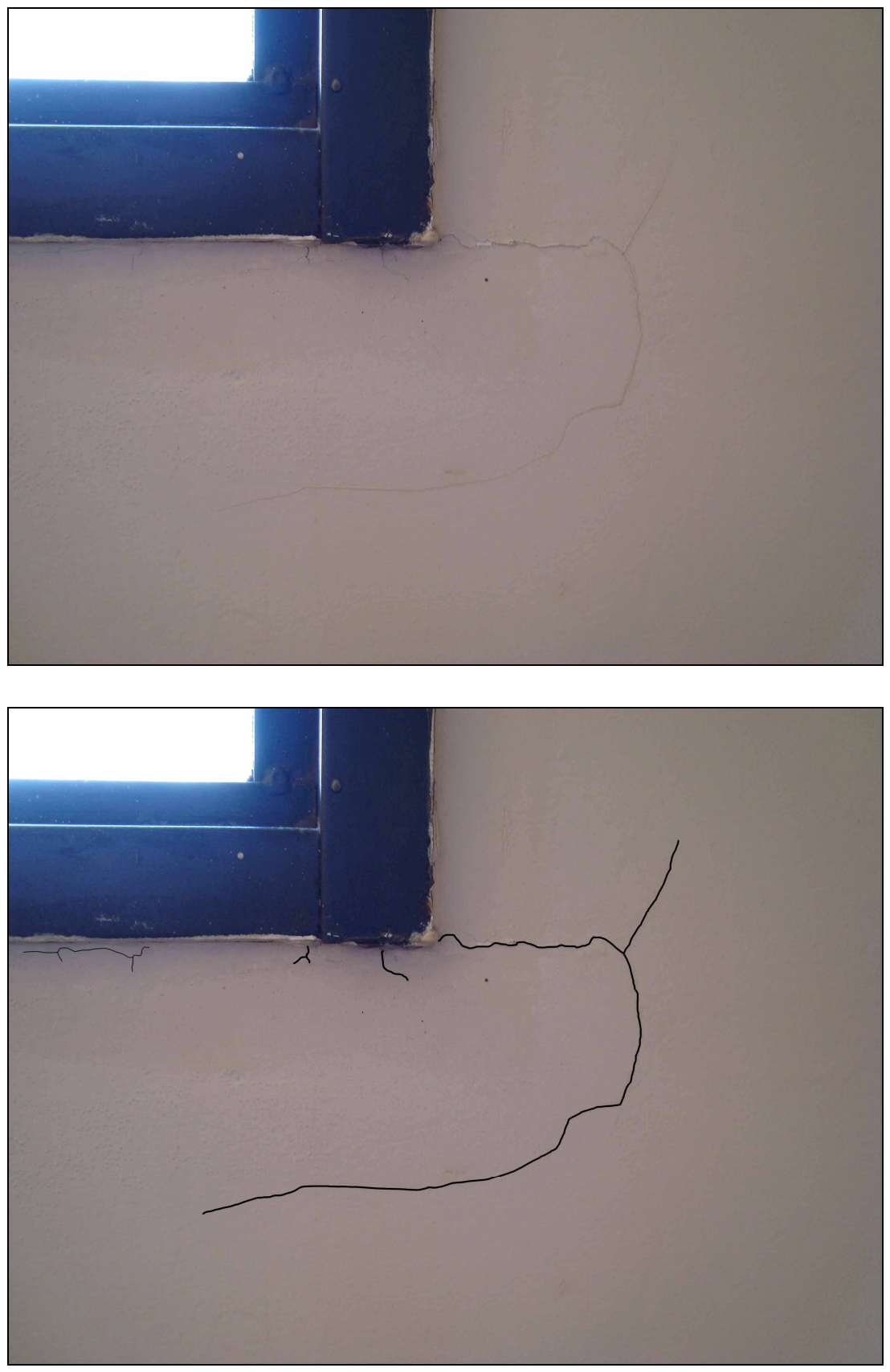

Figura 3.27 - Fissuras em cantos inferiores de aberturas de janelas.

Na Figura 3.27 observa-se a ocorrência de uma fissura com formato diferenciado, a qual se inicia horizontalmente, fica por um pequeno comprimento como vertical e passa a ter uma forma aproximadamente horizontal. Já na Figura 3.28 tem-se uma fissura com um formato preferencialmente horizontal. 

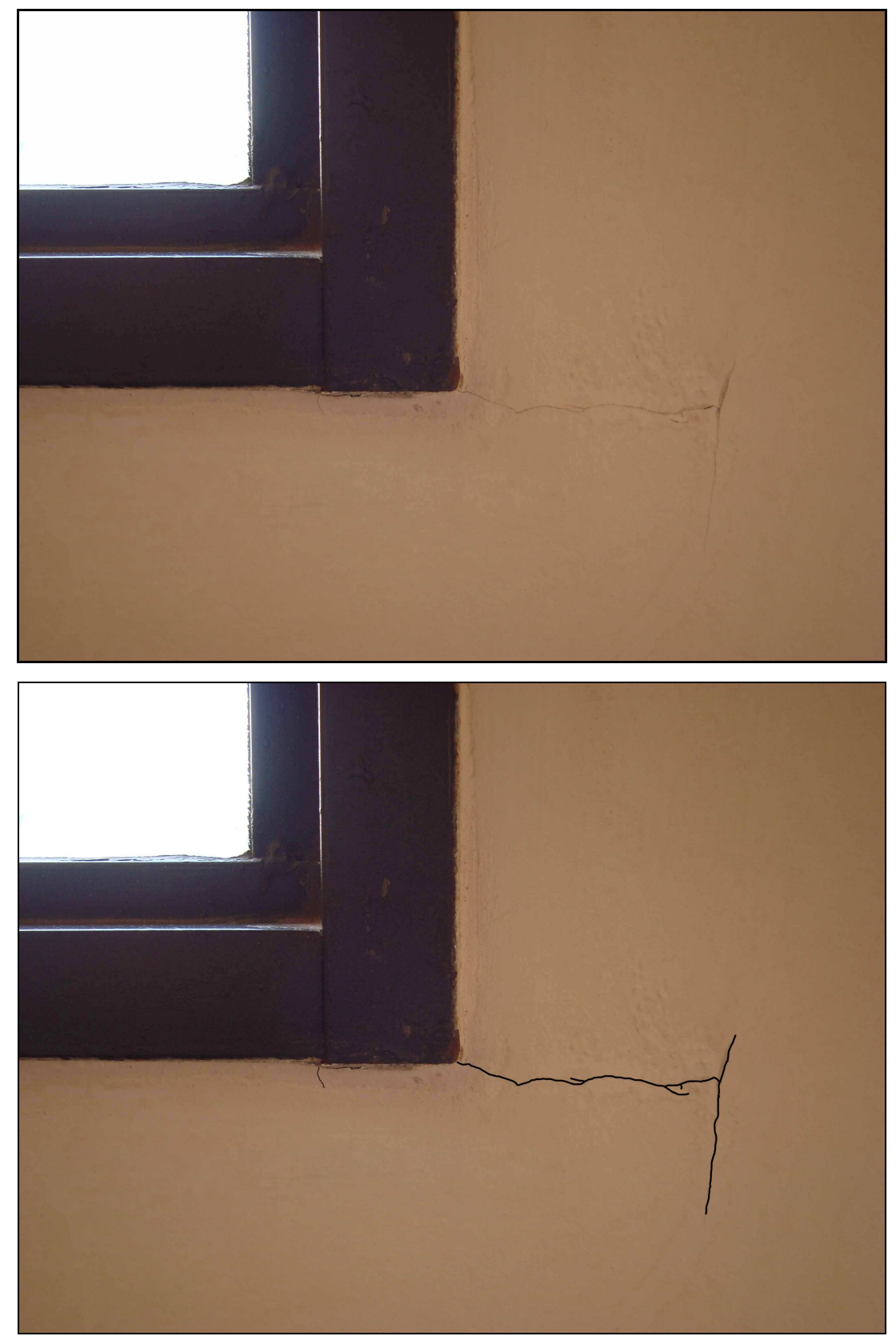

Figura 3.28 - Fissuras em cantos inferiores de aberturas de janelas.

Na Figura 3.29 observa-se uma fissura comum a todas as janelas dessa parede ao longo de todos os andares. Ela inicia-se verticalmente e passa a possuir uma forma horizontal. 

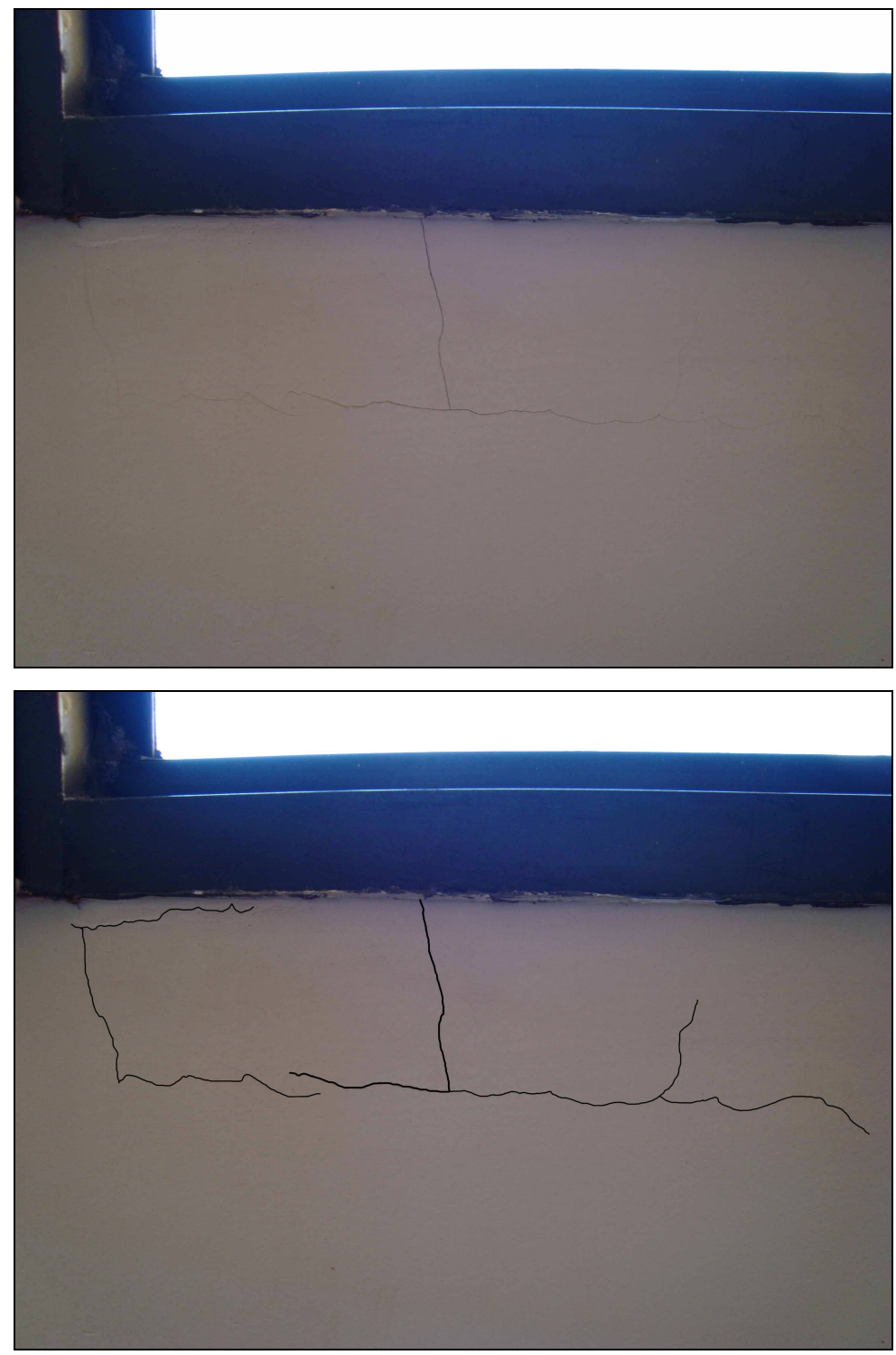

Figura 3.29 - Fissura na parte inferior de abertura de janela.
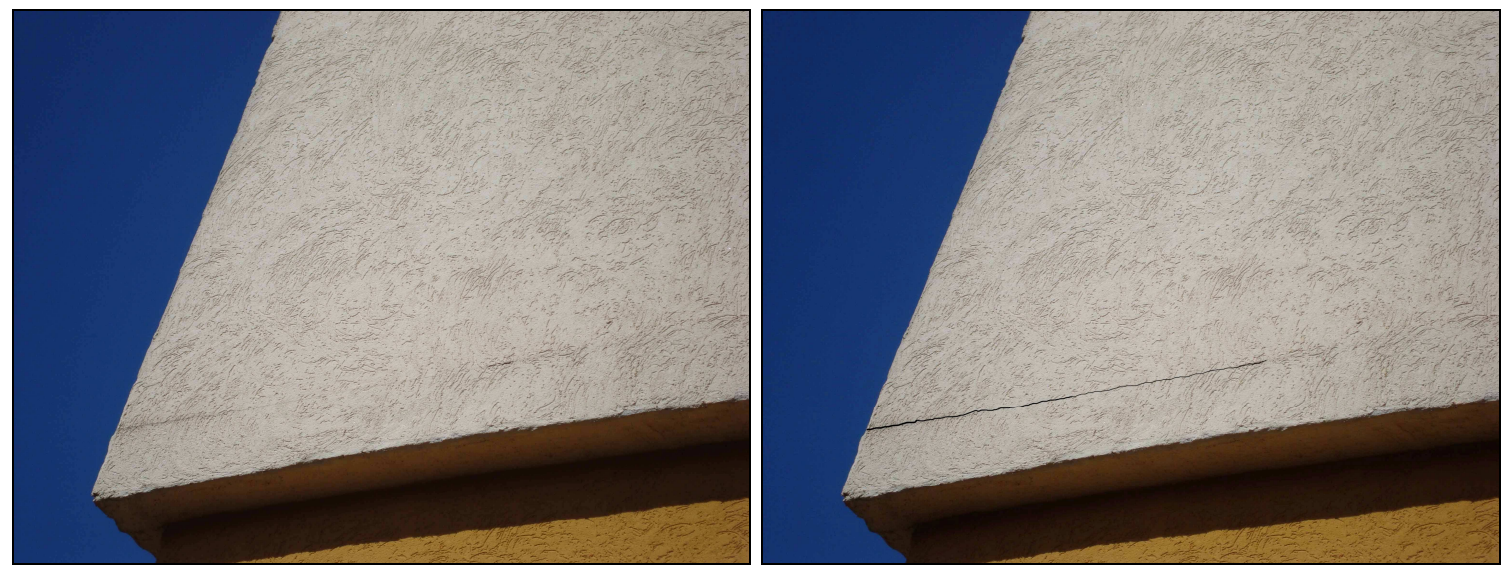

Figura 3.30 - Fissura horizontal ao longo da laje. 
Do último pavimento pôde-se verificar a existência de fissuras horizontais ao longo da altura da laje de cobertura, conforme Figura 3.30.

\subsubsection{Edifício E}

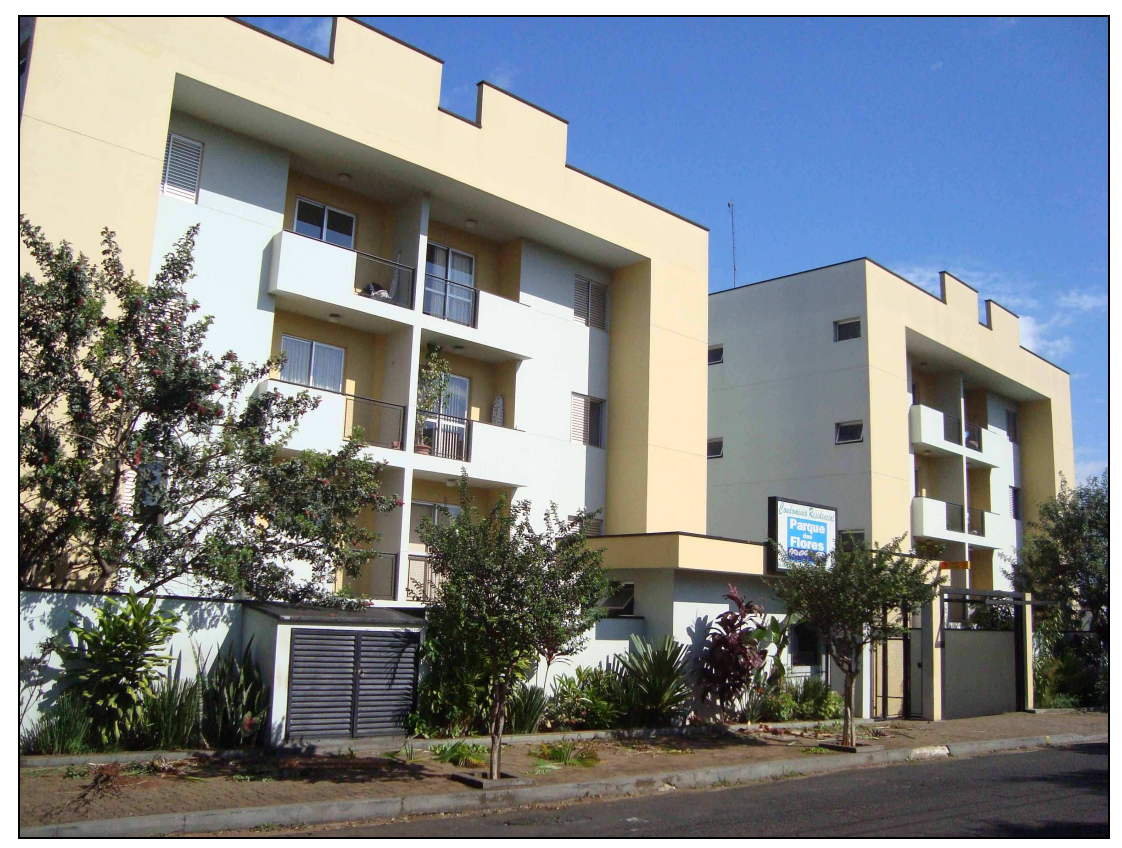

Figura 3.31 - Fachada frontal do Edifício E.

A quinta análise foi realizada num edifício residencial em alvenaria estrutural, com o pavimento térreo mais três andares, localizado Rua Aldino del Nero, $\mathrm{n}^{\circ}$ 95, Bairro Parque Arnold Schimidt, São Carlos/SP.

Assim como nos demais edifícios, foi encontrada uma grande variedade de fissuras em aberturas de portas e janelas, tais como: em cantos inferiores de vão de janela, conforme a Figura 3.32; fissuras horizontais na lateral dos vãos, conforme a Figura 3.33; e fissuras em cantos superiores, como se observa na Figura 3.34. 

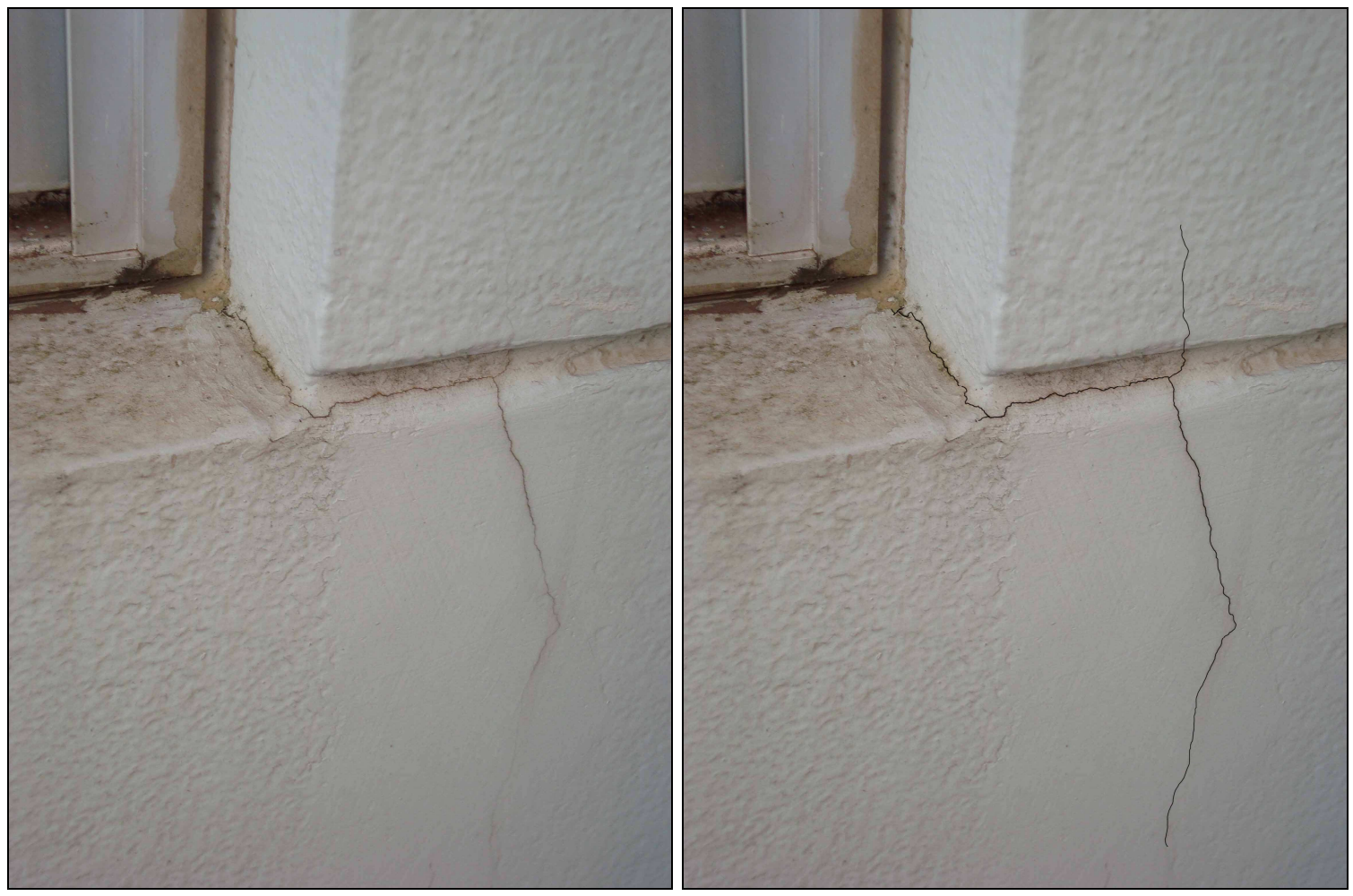

Figura 3.32 - Fissuras em canto de abertura de janela.

Como se pode observar, a fissura da Figura 3.32 tem formato predominantemente vertical, apenas iniciando de forma horizontal.

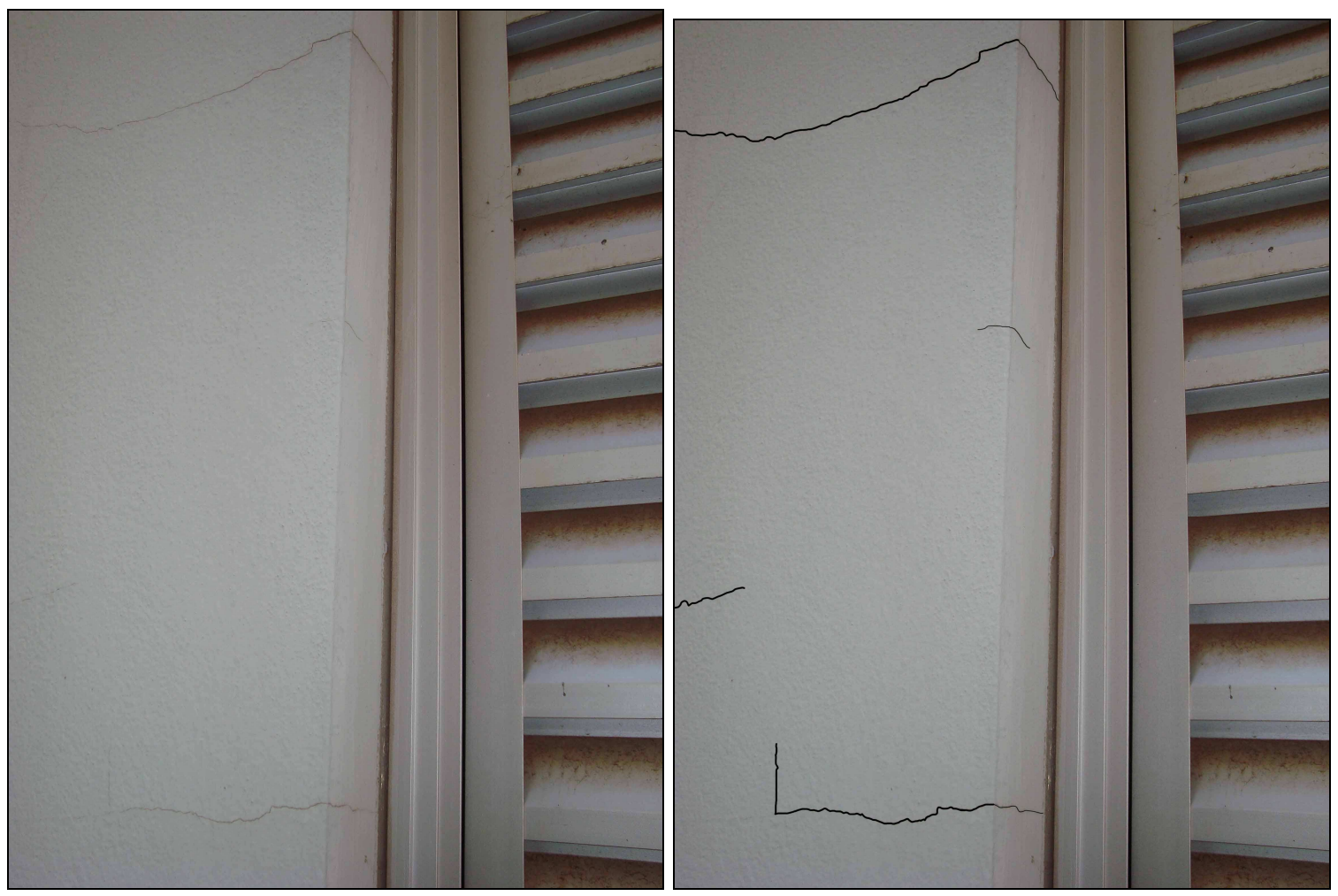

Figura 3.33 - Fissuras horizontais na parte lateral do vão. 
Na Figura 3.33 observam-se fissuras horizontais na lateral do vão de uma janela.
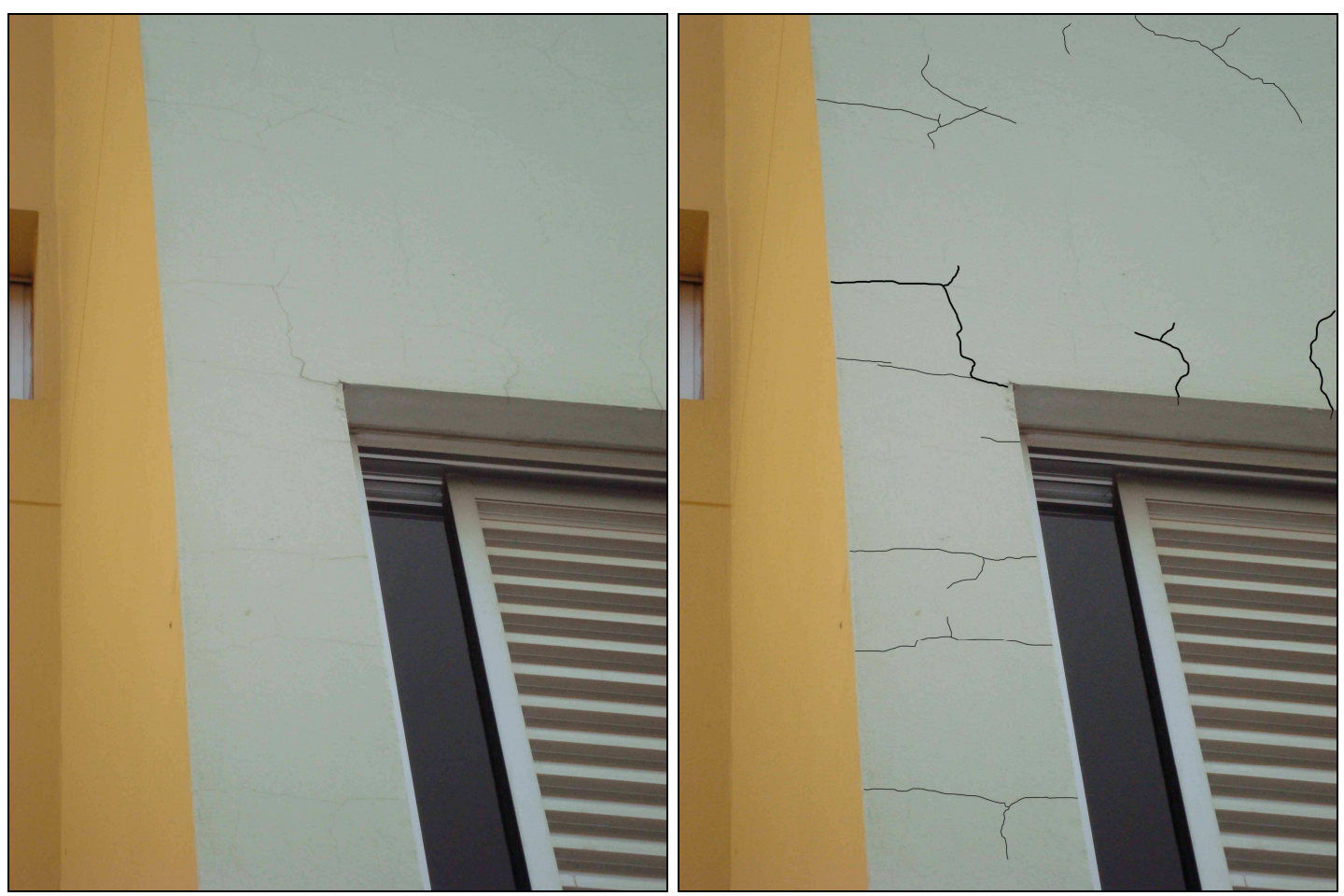

Figura 3.34 - Fissuras nos cantos superiores de aberturas de janelas.

Podem-se observar na Figura 3.34 várias fissuras ao redor do vão de uma janela. Dentre elas, temos as que ocorrem na lateral do vão com formato horizontal, as que ocorrem na parte superior do vão com formato vertical e a que ocorre no canto superior que inicia horizontal, mas tem um formato predominantemente vertical.

A Figura 3.35 mostra um tipo de fissura com características semelhantes à fissura da Figura 3.14. Ela possui formato vertical e localiza-se no encontro entre as lajes de piso de duas sacadas e uma parede em alvenaria estrutural. Nesse caso ocorrem fissuras dos dois lados da parede em alvenaria, pois possui sacadas dos dois lados, o que não ocorre no edifício B. 

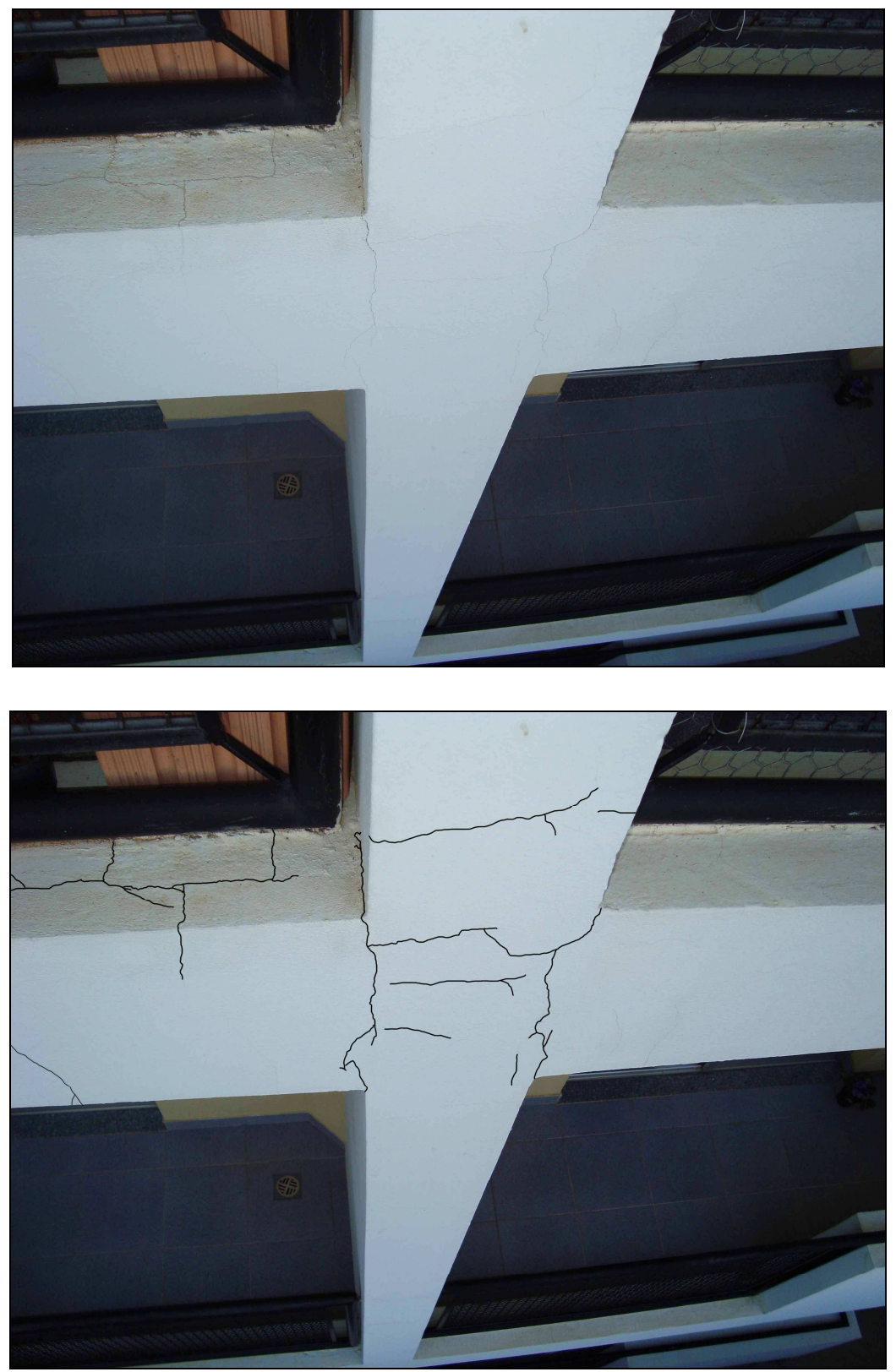

Figura 3.35 - Fissuras causadas pelo carregamento das lajes. 


\section{MOdELAGEM NumÉRICA}

No trabalho de campo foram observados diversos tipos de fissuras e verificou-se que fissuras em paredes com aberturas de portas e janelas são comuns a todos os edifícios analisados. Elas ocorrem tanto na parte superior e inferior quanto nas laterais dos vãos. Diante disso, essa foi a manifestação patológica escolhida para a realização de um estudo teórico visando determinar suas prováveis causas.

$\mathrm{O}$ procedimento de modelagem se inicia com a montagem de um modelo que represente numericamente a geometria, as propriedades e os parâmetros da estrutura para em seguida realizar o processamento através do qual se obtém os resultados. Com isso, chega-se a etapa final do processo que é a análise dos resultados.

Para a realização desse tipo de estudo podem ser feitos três tipos diferentes de modelagens. São elas:

× Micro-modelagem detalhada: as unidades e a argamassa são representadas por elementos contínuos e a interface por elementos descontínuos.

× Micro-modelagem simplificada: as unidades são representadas por elementos contínuos e suas dimensões são expandidas, enquanto o comportamento das juntas de argamassa e da interface é considerado nos elementos descontínuos;

× Macro-modelagem: unidades, argamassas e interface unidade-argamassa são consideradas em conjunto como um meio contínuo. Adota-se um único material homogêneo, contínuo e anisotrópico (ou isotrópico por simplificação), capaz de representar um comportamento médio de alvenaria. A grande vantagem desse processo é que não é necessário representar cada unidade e cada junta de argamassa da alvenaria.

Neste trabalho foi utilizado um procedimento de macro-modelagem considerando-se o material alvenaria como isotrópico, homogêneo e elástico-linear. 
Para as análises foi utilizado o programa computacional ANSYS ® V10.0 baseado no Método dos Elementos Finitos.

Neste trabalho optou-se por adotar uma modelagem em estado plano de tensão onde foram utilizados os elementos PLANE42 e LINK1.

O PLANE42 é um elemento plano quadrilateral definido por quatro nós com dois graus de liberdade em cada um deles (translações segundo as direções x e y). Ele foi utilizado em discretização de paredes, cintas, vergas, contravergas e reforços grauteados colocados nas laterais de vãos de portas e janelas.
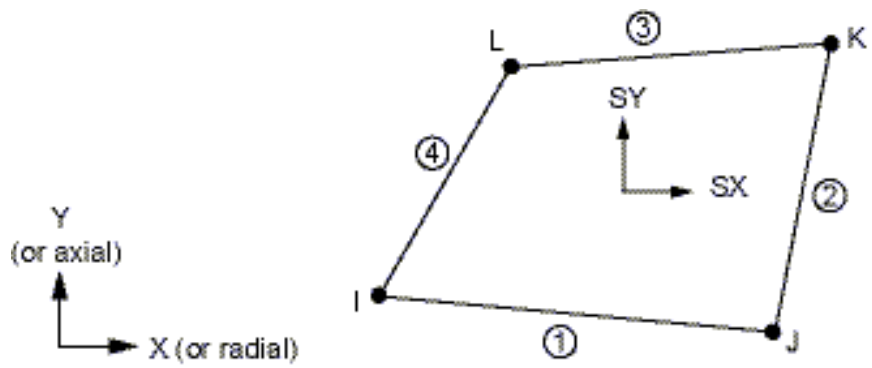

Figura 4.1 - Elemento PLANE42

O LINK1 é um elemento uniaxial com tensão, compressão e capacidades de flexão, com três graus de liberdade em cada nó (translações segundo as direções x e y e rotação em torno do eixo z). Ele foi utilizado em discretização das barras utilizadas nas vergas, nas contravergas, nas cintas e nos reforços laterais.

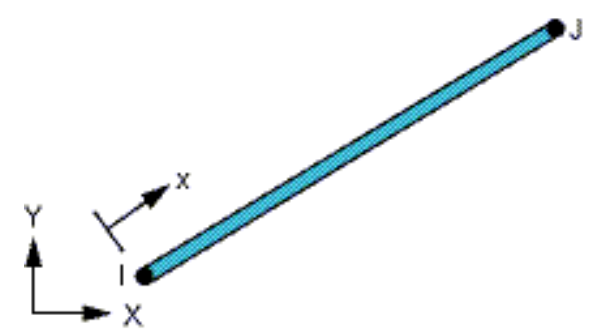

Figura 4.2 - Elemento LINK1

\subsection{PROPRIEDADES}

Os modelos estudados consistem em paredes em alvenaria estrutural com o comportamento linear isotrópico. As propriedades dos materiais adotados são apresentadas na tabela 4.1 . 


\begin{tabular}{llr}
\hline \multicolumn{1}{c}{ PARÂMETRO } & VALOR \\
\hline ALVENARLA & & \\
& Módulo de Elasticidade Longitudinal (Ealv) & $6400 \mathrm{MPa}$ \\
& Coeficiente de Poisson (v) & 0.2 \\
\hline GRAUTE & Módulo de Elasticidade Longitudinal (Eg) & $22400 \mathrm{MPa}$ \\
& Coeficiente de Poisson (v) & 0.2 \\
\hline ALVENARLA & & $14400 \mathrm{MPa}$ \\
GRAUTEADA & Módulo de Elasticidade Longitudinal (Ealvg) & 0.2 \\
\hline CONCRETO & Coeficiente de Poisson (v) & \\
& Módulo de Elasticidade Longitudinal (Ec) & $28000 \mathrm{MPa}$ \\
& Coeficiente de Poisson (v) & 0.2 \\
\hline AÇO & Módulo de Elasticidade Longitudinal (Ea) & $205000 \mathrm{MPa}$ \\
& Coeficiente de Poisson (v) & 0.3 \\
\hline
\end{tabular}

Tabela 4.1 - Parâmetros utilizados nos materiais dos modelos

O valor do módulo de elasticidade da alvenaria foi calculado segundo sugestão de RAMALHO (2003) considerando um $f_{\mathrm{p}}$ igual a $8 \mathrm{MPa}$, conforme segue abaixo:

$$
\begin{aligned}
& E=800 . f_{p} \\
& E=800.8 \\
& E=6400 \mathrm{MPa}
\end{aligned}
$$

Os valores dos módulos de elasticidade do concreto e do graute são, respectivamente:

$$
\begin{array}{ll}
E_{c}=5600 \cdot \sqrt{f_{c k}} & E_{g}=5600 \cdot \sqrt{f_{c k}} \\
E_{c}=5600 \cdot \sqrt{25} & E_{g}=5600 \cdot \sqrt{16} \\
E_{c}=28000 \mathrm{MPa} & E_{g}=22400 \mathrm{MPa}
\end{array}
$$


O valor do módulo de elasticidade da alvenaria grauteada que será utilizado para representar a canaleta foi obtido através da média dos módulos de elasticidade do bloco e do graute.

O bloco foi considerado com $50 \%$ de vazios e está preenchido com graute, sendo assim o valor do módulo de elasticidade longitudinal é igual a:

$$
\begin{aligned}
& E_{a l v}=\left(E_{a l v}+E_{g}\right) \div 2 \\
& E_{a l v}=(6400+22400) \div 2 \\
& E_{a l v}=14400 M P a
\end{aligned}
$$

O módulo de elasticidade do aço para as barras de armadura foi usado segundo o que sugere a Norma 08800/1986 - Projeto e Execução de Estruturas de Aço em Edifícios.

\subsection{CARACTERÍSTICAS dos MOdELOS}

Para o estudo deste trabalho foram adotados os seguintes dados:

× Paredes com altura de dois pisos e altura total de 5,60m;

× Carga no valor de $150 \mathrm{kN} / \mathrm{m}$ aplicada na parte superior da parede.

× Desconsiderou-se o peso próprio.

× Condições de contorno: o primeiro nó da base, localizado na cota $(0,0)$ possui restrições na direção x e y e os demais nós da base possuem restrições apenas na direção y.

Em todos os modelos foram adotadas dimensões padrões, conforme a Figura 4.3. Para a consideração das aberturas foram adotadas portas ou janelas. Eventualmente, foram ainda acrescentados vergas, contravergas, reforços laterais e cintas à meia altura, conforme indicado em cada caso. Diante dessas variações, foram analisadas suas influências em relação a distribuição de tensões.

As portas utilizadas possuem 2,20m de altura e $1,00 \mathrm{~m}$ de largura e estão centralizadas horizontalmente na parede. As janelas possuem 1,20m de altura, 1,40m de largura e a distância da base ao peitoril mede 1,00m. Assim como as portas as janelas estão centralizadas horizontalmente na parede. 
Todas as vergas foram consideradas com a medida do vão da abertura mais a medida de um bloco para cada lado. Neste trabalho o bloco está sendo considerado com $40 \mathrm{~cm}$ de largura e $20 \mathrm{~cm}$ de altura. Dessa forma, as vergas utilizadas em vãos de portas medem $1,80 \mathrm{~m}$ de largura e $0,20 \mathrm{~m}$ de altura e as vergas e contravergas utilizadas em vãos de janelas medem 2,20 m de largura e 0,20 m de altura.

Numa modelagem podemos substituir a quantidade de pavimentos acima do pavimento analisado por um carregamento correspondente, diante disso optou-se por considerar uma parede com altura equivalente a dois pisos. $\mathrm{O}$ segundo piso foi utilizado visando evitar a ocorrência de perturbação de tensão devido à aproximação da aplicação da carga com a região de concentração de tensões no pavimento analisado. Por esse motivo, a carga será aplicada no segundo pavimento, no entanto o pavimento analisado será apenas o inferior.

A carga de $150 \mathrm{kN} / \mathrm{m}$ considerada na modelagem corresponde a uma carga aproximada de $8,5 \mathrm{kN} / \mathrm{m}^{2}$ por pavimento e uma área de influência de $2,20 \mathrm{~m}$, o que resulta numa carga de $18,7 \mathrm{kN} / \mathrm{m}$. Considerando esse valor em oito pavimentos temos aproximadamente os $150 \mathrm{kN} / \mathrm{m}$ considerado.

Os painéis estudados seguem abaixo conforme cada caso:

\subsubsection{PAINEL DE PAREDE SIMPLES, SEM ABERTURA}

Todos os painéis estudados possuem dimensões conforme apresentado abaixo:

A Figura 4.3 representa uma parede com altura equivalente a dois pisos, considerando largura de 4,00m e um pé direito de $2,70 \mathrm{~m}$, sendo $2,60 \mathrm{~m}$ de blocos de alvenaria e $0,10 \mathrm{~cm}$ de bloco de canaleta grauteada. Acima dessa canaleta, considerou-se uma laje com $0,10 \mathrm{~m}$. 


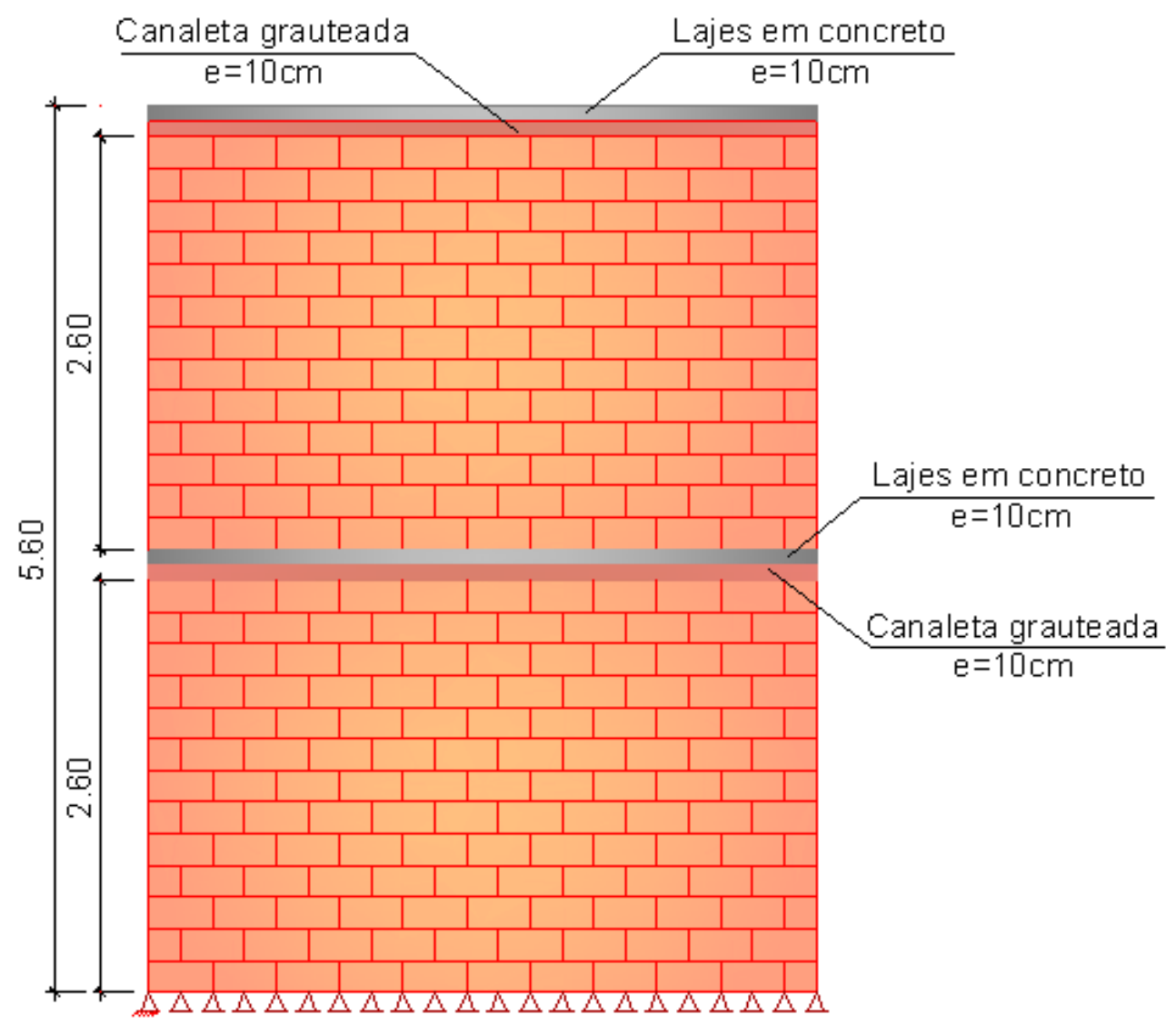

Figura 4.3 - Especificações das dimensões comuns aos painéis

4.2.2 PAINÉIS DE PAREDES COM ABERTURAS DE PORTAS;

\subsubsection{Painel de Parede Com aberturas de Portas, Sem Reforço}

O painel da Figura 4.4 representa uma parede com aberturas de portas sem a colocação de vergas sobre as aberturas. Dessa forma pretende-se analisar o caminhamento das tensões devido a abertura que inicia a uma altura de $2,20 \mathrm{~m}$ e segue até a base da alvenaria. 


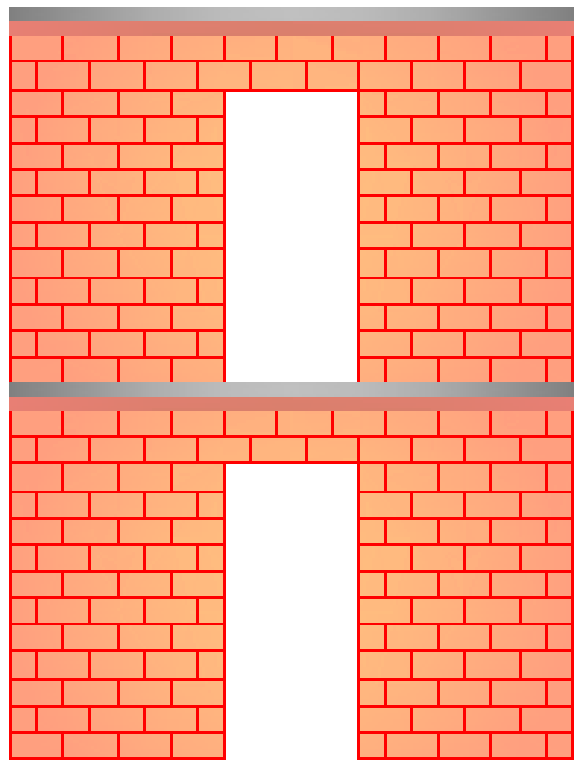

Figura 4.4 - Painel de parede com aberturas de portas sem reforço

\subsubsection{Painel De Parede Com aberturas de Portas Com Vergas}

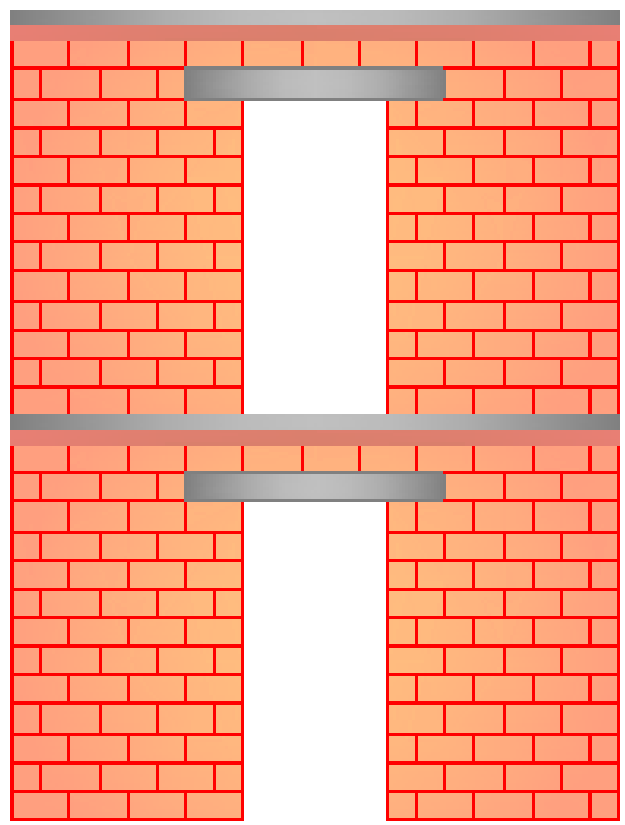

Figura 4.5 - Painel de parede com aberturas de portas com vergas

O painel da Figura 4.5 representa uma parede com aberturas de portas, assim como o painel da Figura 4.4, onde neste caso foram acrescentadas vergas sobre as 
aberturas. Dessa forma, pretende-se verificar a influência das vergas na distribuição de tensões.

Para a representação das barras das vergas, assim como das contravergas e reforços laterais utilizados nos modelos posteriores, foi utilizada uma área equivalente a uma barra de $10 \mathrm{~mm}$ de diâmetro.

\subsubsection{Painel de Parede Com aberturas de Portas com Vergas e REFORÇOS LATERAIS}

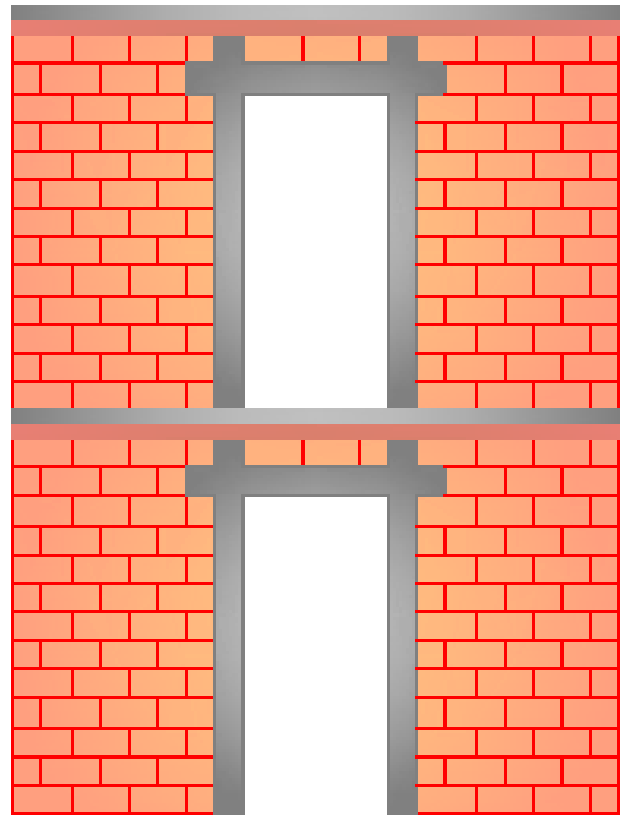

Figura 4.6 - Painel de parede com aberturas de portas com vergas e reforços laterais

O painel da Figura 4.6 representa uma parede com aberturas de portas, com a utilização de vergas e reforços laterais. Esses reforços laterais possuem as mesmas larguras das vergas e são dispostas no sentido longitudinal nas laterais das aberturas desde a base da parede até a canaleta.

\subsubsection{PAINÉIS DE PAREDES COM ABERTURAS DE JANELAS}

\subsubsection{Painel de Parede com aberturas de JANelas, SEM Reforço}

Esse painel representa uma parede com aberturas de janelas sem a colocação de qualquer tipo de reforço. Dessa forma pretende-se analisar o caminhamento das tensões 
devido à abertura que inicia a uma altura de 2,20m e não segue até a base da alvenaria, como é o caso da Figura 4.7, ficando a uma altura de 1,0m da base.

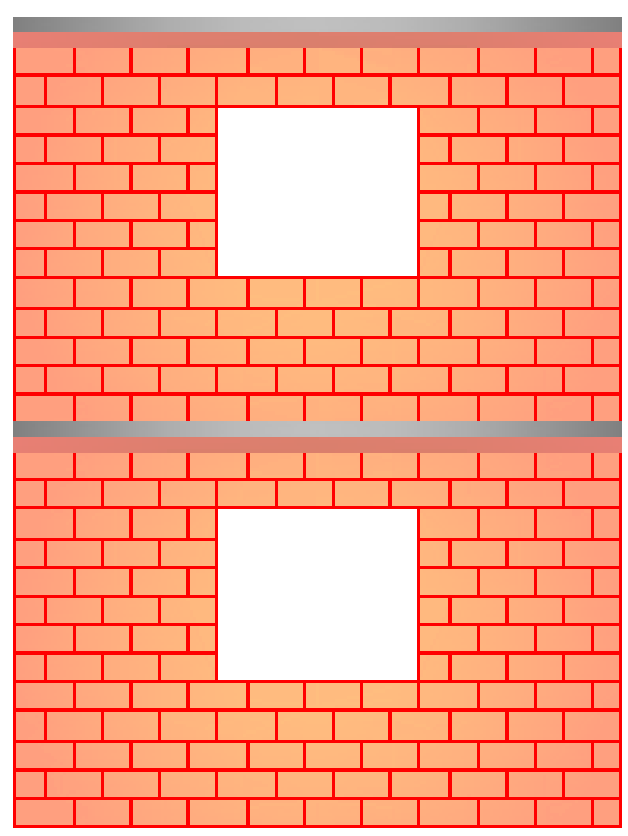

Figura 4.7 - Painel de parede com aberturas de janelas sem reforço

\subsubsection{Painel De Parede com aberturas de Janelas Com Vergas}

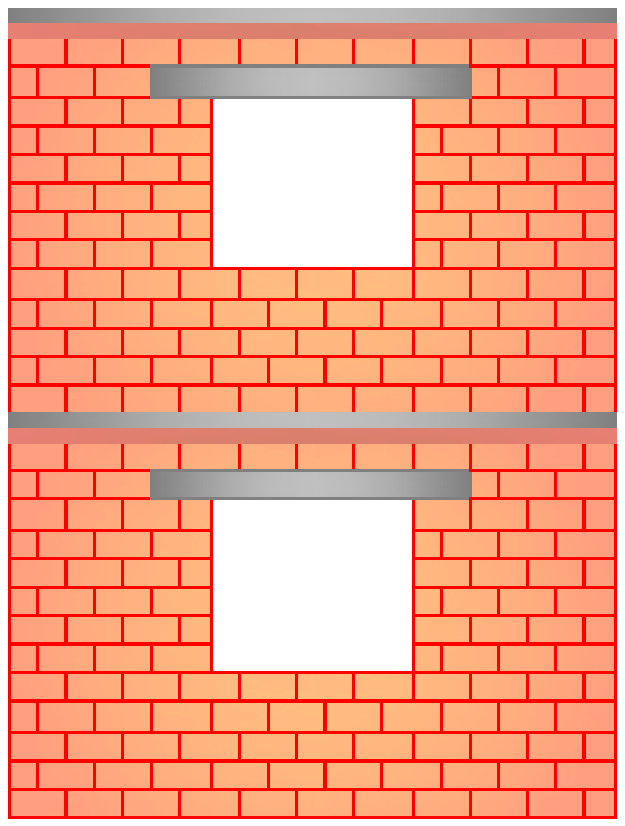

Figura 4.8 - Painel de parede com aberturas de janelas com vergas 
O painel da Figura 4.8 representa uma parede com aberturas de janelas, assim como o painel da Figura 4.7, onde neste caso foram acrescentadas vergas sobre as aberturas. Assim como a Figura 4.5, pretende-se verificar a influência da verga na distribuição de tensões nesse tipo de abertura.

\subsubsection{Painel de Parede com aberturas de Janelas com Vergas E CONTRAVERGAS}

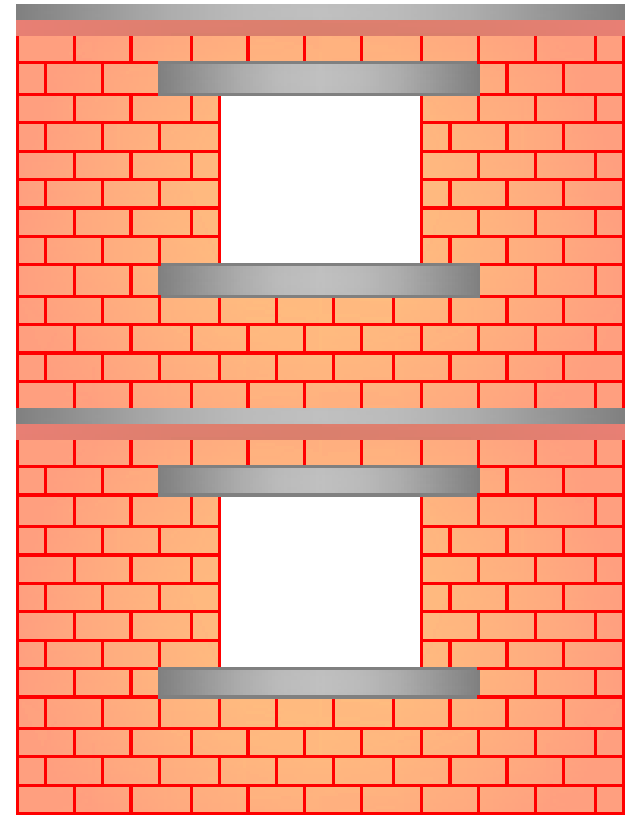

Figura 4.9 - Painel de parede com aberturas de janelas com vergas e contravergas

Esse painel representa uma parede com aberturas de janelas onde foram acrescentadas além das vergas sobre as aberturas, contravergas sob as aberturas visando verificar a influência de mais esse reforço na distribuição de tensões.

\subsubsection{Painel de Parede com aberturas de Janelas Com Vergas, CONTRAVERGAS E REFORÇOS LATERAIS CURTOS}

O painel da Figura 4.10 representa uma parede com aberturas de janelas com a utilização de vergas, contravergas e reforços laterais curtos. Esses reforços laterais possuem as mesmas dimensões que as vergas e as contravergas sendo dispostas no sentido longitudinal nas laterais das aberturas. 
Essa é uma configuração utilizada para verificar a influência da distribuição de tensões também nas laterais dos vãos, visto que os painéis anteriores ou não possuíam reforço ou possuíam apenas nas partes superior e/ou inferior dos vãos.

Esse reforço é definido como curto devido seu comprimento ultrapassar o vão apenas no comprimento de um bloco, ou seja, $40 \mathrm{~cm}$, não se prolongando por toda a parede.

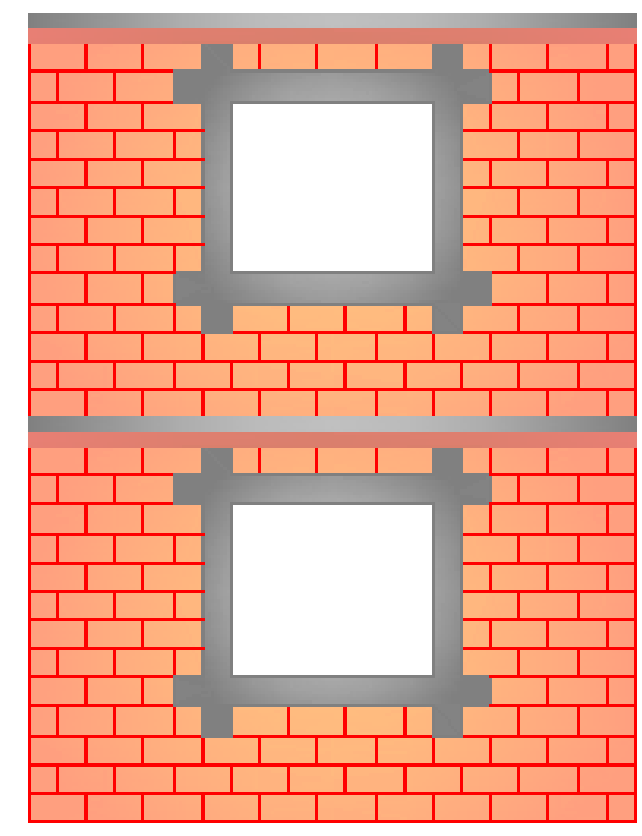

Figura 4.10 - Painel de parede com aberturas de janelas com vergas, contravergas e reforços laterais curtos

\subsubsection{Painel De Parede Com aberturas de JANElas CoM VERGaS, CONTRAVERGAS E REFORÇOS LATERAIS LONGOS}

Esse painel difere do painel da Figura 4.11 por possuir um prolongamento dos reforços laterais até a base, visando verificar se essa alteração modifica a distribuição de tensões. 


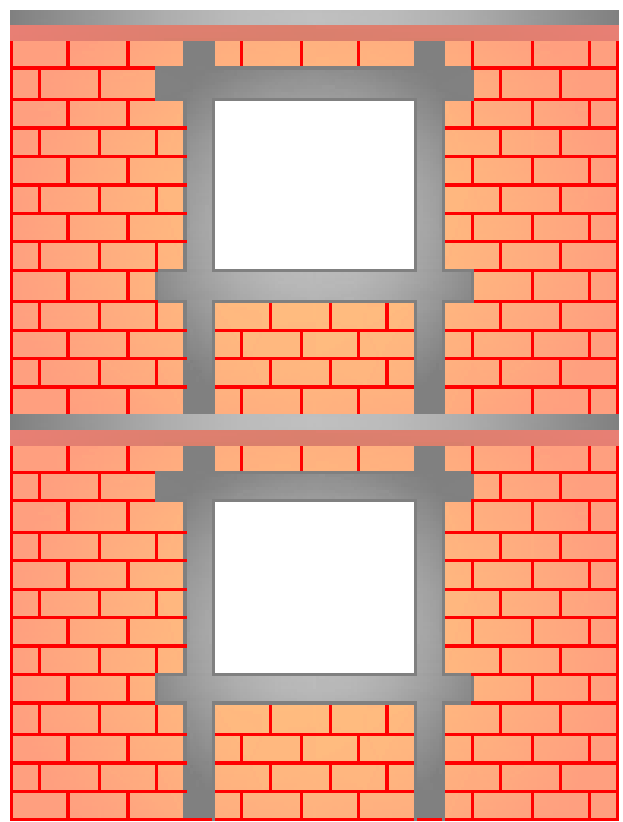

Figura 4.11 - Painel de parede com aberturas de janelas com vergas, contravergas e reforço lateral longo

\subsubsection{PAINEL DE PAREDE COM ABERTURAS DE JANELAS COM VERGAS E CINTA À MEIA ALTURA DA PAREDE}

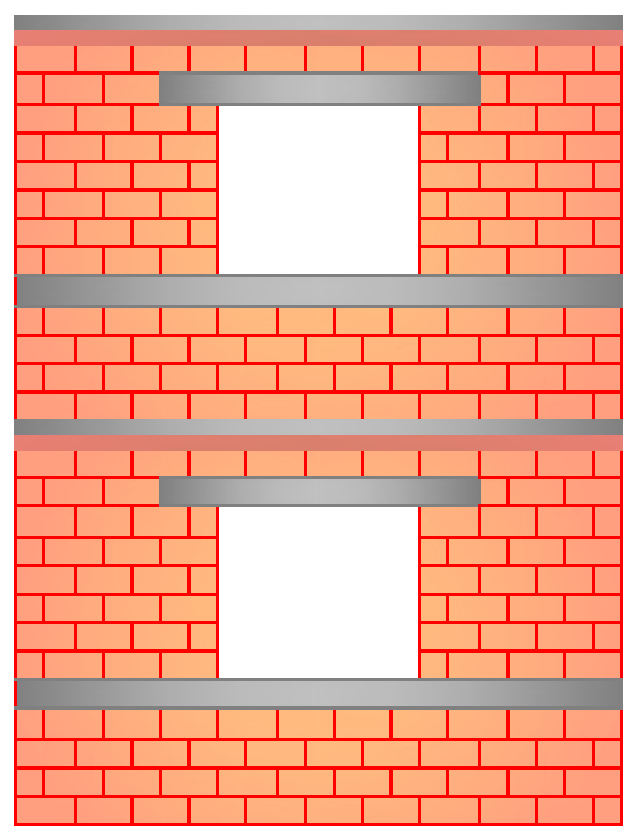

Figura 4.12 - Painel de parede com aberturas de janelas com vergas e cinta à meia altura da parede 
Esse painel representa uma parede com aberturas de janelas com a utilização de vergas e cinta à meia altura da parede, que são reforços na base da aberturas que se estendem ao longo de toda a lateral da parede.

Essa configuração foi escolhida por ser usualmente utilizada na prática. Ela é usualmente utilizada em paredes externas, devido à grande variação de temperatura.

\subsection{REDE DE ELEMENTOS FINITOS}

Para a rede de elementos finitos optou-se por utilizar dimensões máximas de $5 \mathrm{~cm}$ em elementos com formato quadrilateral, conforme o que se apresenta nas Figura 4.13, 4.14 e 4.15 .

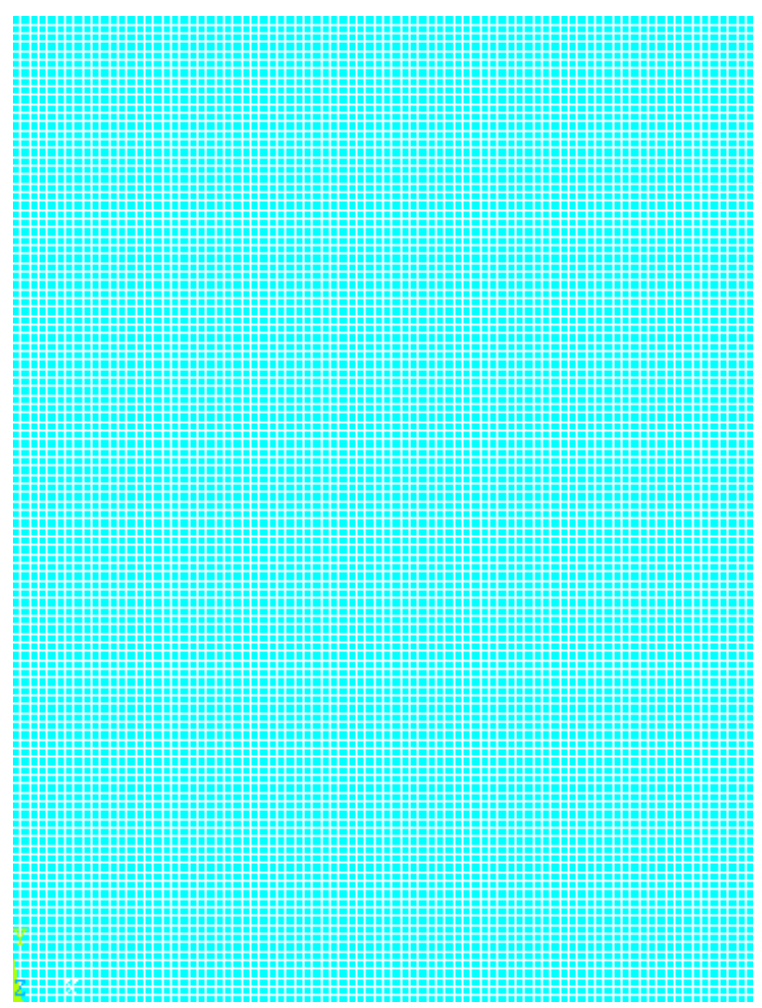

Figura 4.13 - Rede do modelo de parede sem aberturas. 


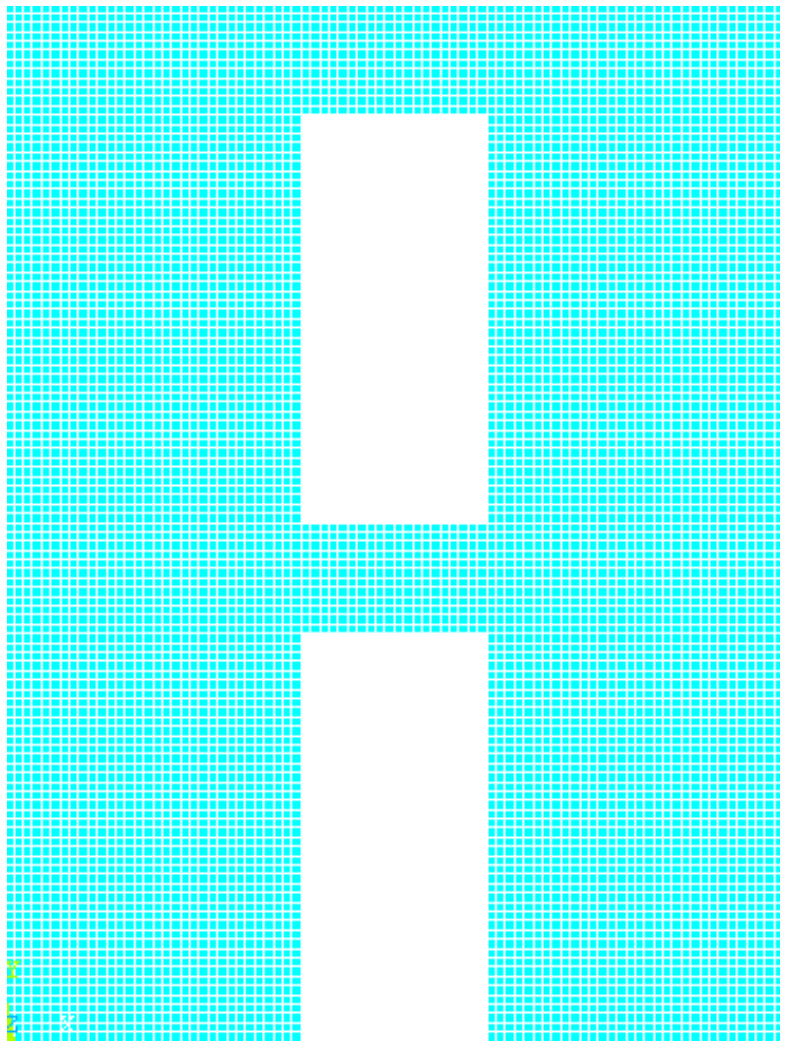

Figura 4.14 - Rede referente aos modelos de parede com aberturas de portas.

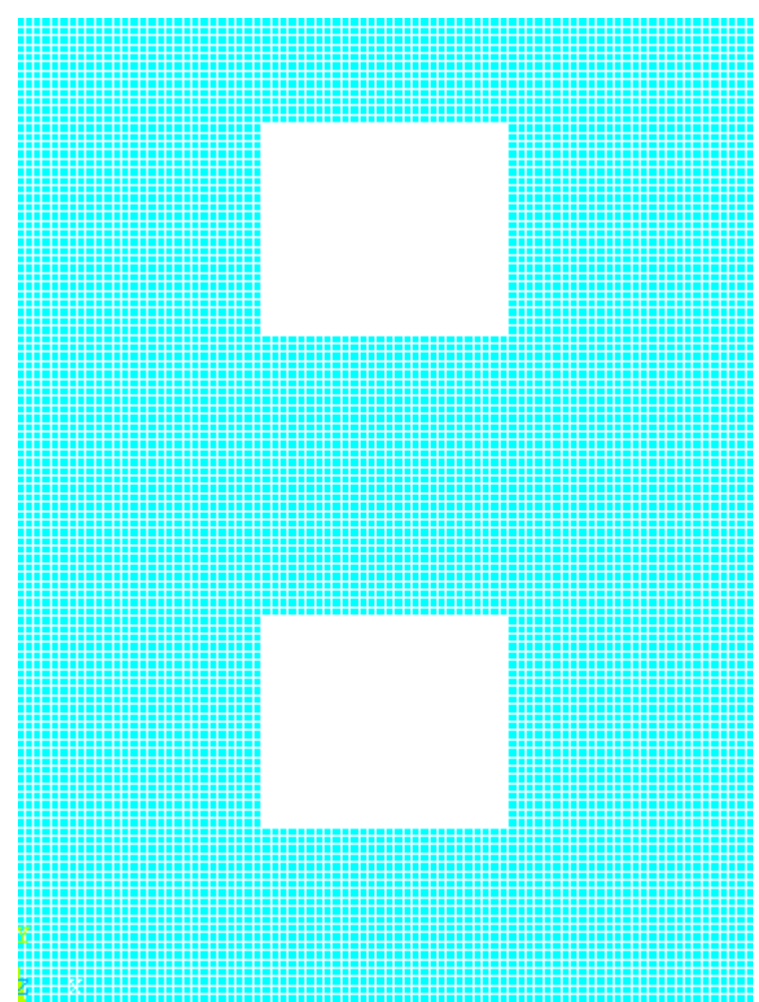

Figura 4.15 - Rede referente aos modelos de paredes com aberturas de janelas. 
É importante ressaltar que com essas dimensões dos elementos finitos, a rede coincide com as medidas das vergas, contravergas, reforços laterais e cinta à meia altura. Por esse motivo a malha fica uniforme não possuindo aparentemente diferença entre uma malha com ou sem esses reforços.

Essa diferença é imposta nas propriedades dos elementos, o que faz com que eles trabalhem de forma distinta ao serem carregados.

\subsection{Processamento}

As modelagens e o processamento dos modelos foram feitas no ANSYS 10.0 e para uma melhor visualização dos resultados optou-se por utilizar o programa de pósprocessamento GMEC, disponível no Departamento de Engenharia de Estruturas da EESC-USP e de autoria de Rodrigo Ribeiro Paccola. 


\section{ANÁlise dos RESUltados}

Os modelos foram feitos com apenas dois pavimentos para se eliminar a zona de perturbação das tensões, que ocorre no pavimento no qual é aplicado o carregamento. Além disso, é interessante ressaltar que a carga de $150 \mathrm{kN} / \mathrm{m}$, utilizada em todos os modelos, equivale a um carregamento de 8 pavimentos, conforme descrita no item 4.2 Características dos Modelos.

$\mathrm{Na}$ análise dos resultados somente no modelo simples sem abertura serão apresentados os valores da tensão principal I, que é a tensão principal positiva, considerando-se dois pavimentos conforme foi realizada a modelagem. Nos demais casos serão apresentados os valores da tensão principal I apenas para o pavimento inferior, que é o pavimento que será analisado.

Para cada caso apresenta-se um painel com limites de tensões de tração diferentes, isso ocorre para uma melhor visualização dos resultados em cada um deles. Dessa forma no painel onde o limite máximo de tração é, por exemplo, $0.20 \mathrm{MPa}$, serão apresentados os valores de zero a $0.20 \mathrm{MPa}$.

Alguns painéis serão apresentados mais de uma vez, modificando-se apenas a variação de tensões de tração para uma melhor comparação com os modelos semelhantes.

\subsection{PAINEl DE PAREDE SIMPleS SEM ABERTURA:}

- Tensões principais I, com limite de 0 a $0.30 \mathrm{MPa}$ :

Nesse painel pode-se observar que as tensões de tração encontram-se nas canaletas e nas lajes, assim na parede em alvenaria estrutural a tensão de tração é nula, o que implica dizer que ela está totalmente comprimida e de forma uniforme.

Nesse primeiro painel, tem-se a tensão de tração com variação entre 0 e $0.30 \mathrm{MPa}$, mas observa-se que na laje em concreto armado, na parte azul marinho, os valores ultrapassam esse limite. No entanto, na parede em alvenaria estrutural a tensão de tração é 
sempre nula, não necessitando assim de variações dos intervalos de tensões para observar quais os valores máximos que estão sendo transmitidos a ela.

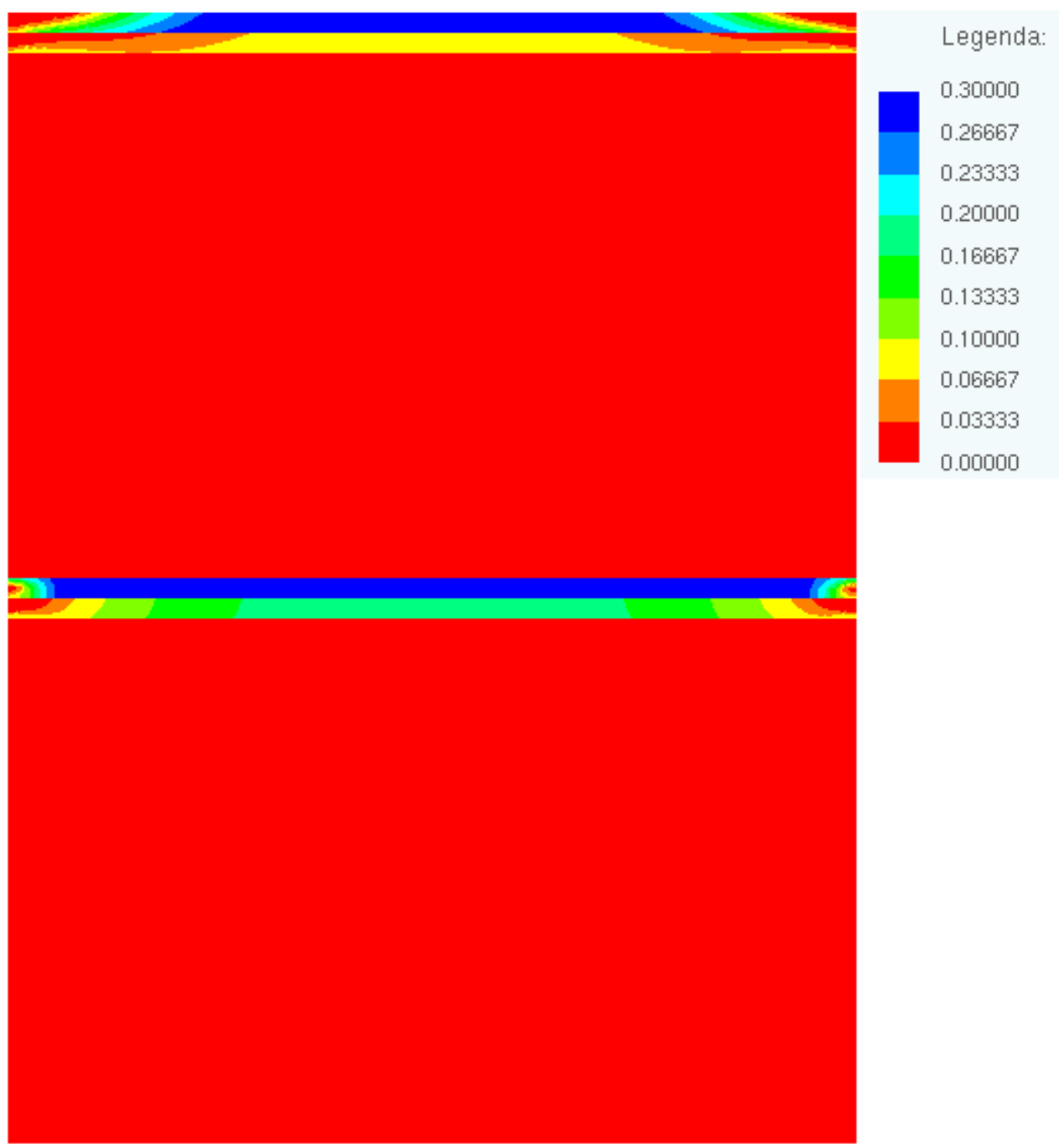

Figura 5.1 - Tensões principais I em painel de parede simples sem aberturas, com valores entre 0 e $0.30 \mathrm{MPa}$.

\subsection{Painéis de PAREDES COM ABERTURA DE PORTA}

\subsubsection{PORTA SEM REFORÇOS}

- Tensões principais I, com limite de 0 a 0.30MPa: 
Delimitando a apresentação dos resultados para os limites de 0 a $0.30 \mathrm{MPa}$ podemos ver o que realmente ocorre nas proximidades dos vãos com relação as tensões de tração.

Na parte superior do vão ocorre uma tensão de tração considerada importante na alvenaria estrutural, visto que a resistência à tração segundo a Norma 10837/1989 pode variar entre 0.10 e $0.15 \mathrm{MPa}$ e os valores apresentados chegam em alguns pontos a 0.30MPa. Diante disso, podemos utilizar esse local como sendo um ponto importante para comparações com os demais painéis dado que essa é uma área favorável ao aparecimento de fissuras.

Verifica-se ainda que as laterais da abertura não sofrem com concentração de tensão de tração, sendo nula nessa localidade.

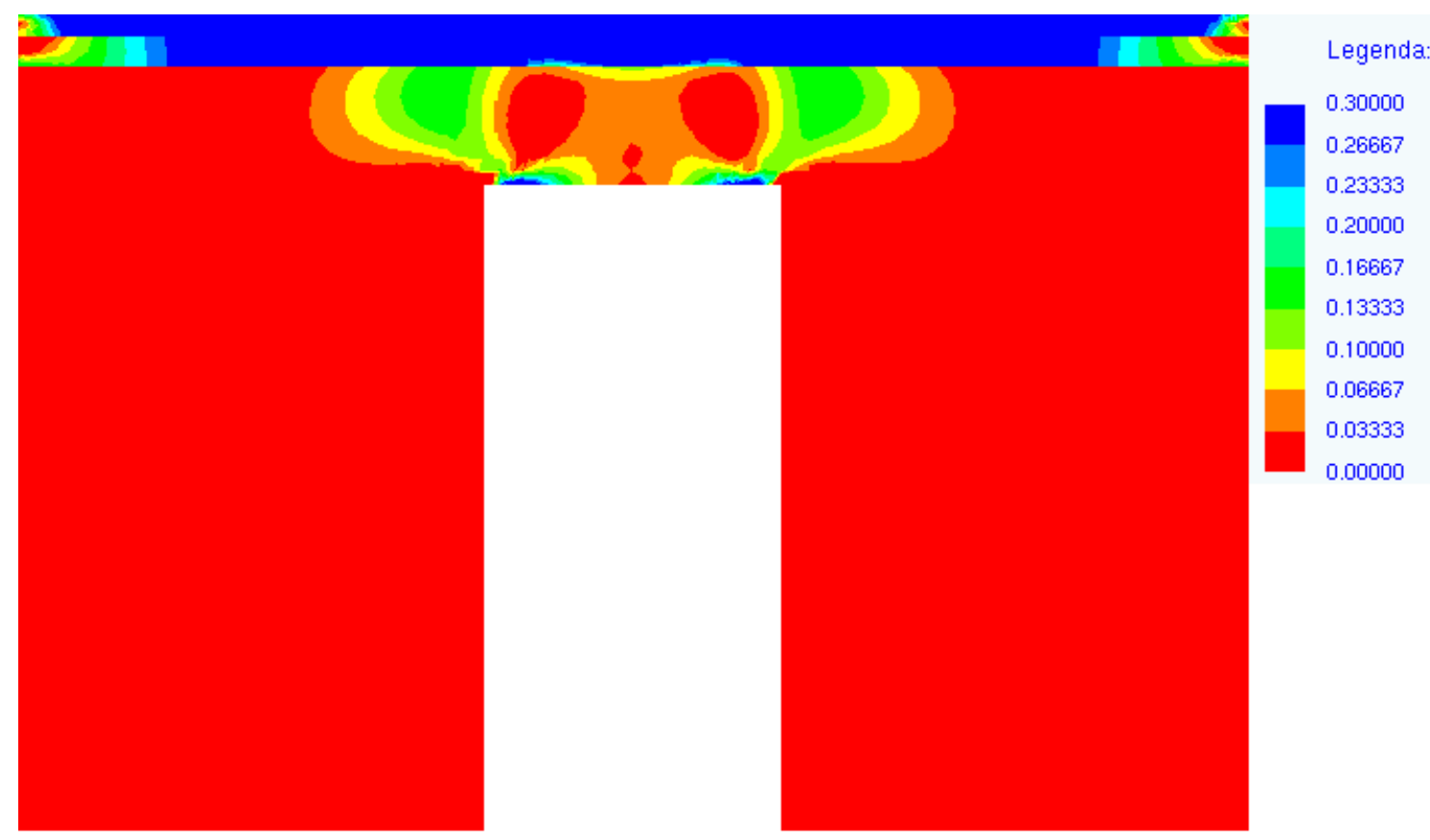

Figura 5.2 - Tensões principais I em painel de parede com abertura de porta sem reforço, com valores entre 0 e $0.30 \mathrm{MPa}$.

- Tensões principais I, com limite de 0 a $0.18 \mathrm{MPa}$ :

Alterando os limites de tensão de tração para 0 e $0.18 \mathrm{MPa}$, observamos duas áreas mais concentradas na parte superior do vão, onde essas tensões ultrapassam o valor de 
$0.18 \mathrm{MPa}$, confirmando mais ainda que essa é uma área crítica para o aparecimento de fissuras provenientes de tensões de tração.

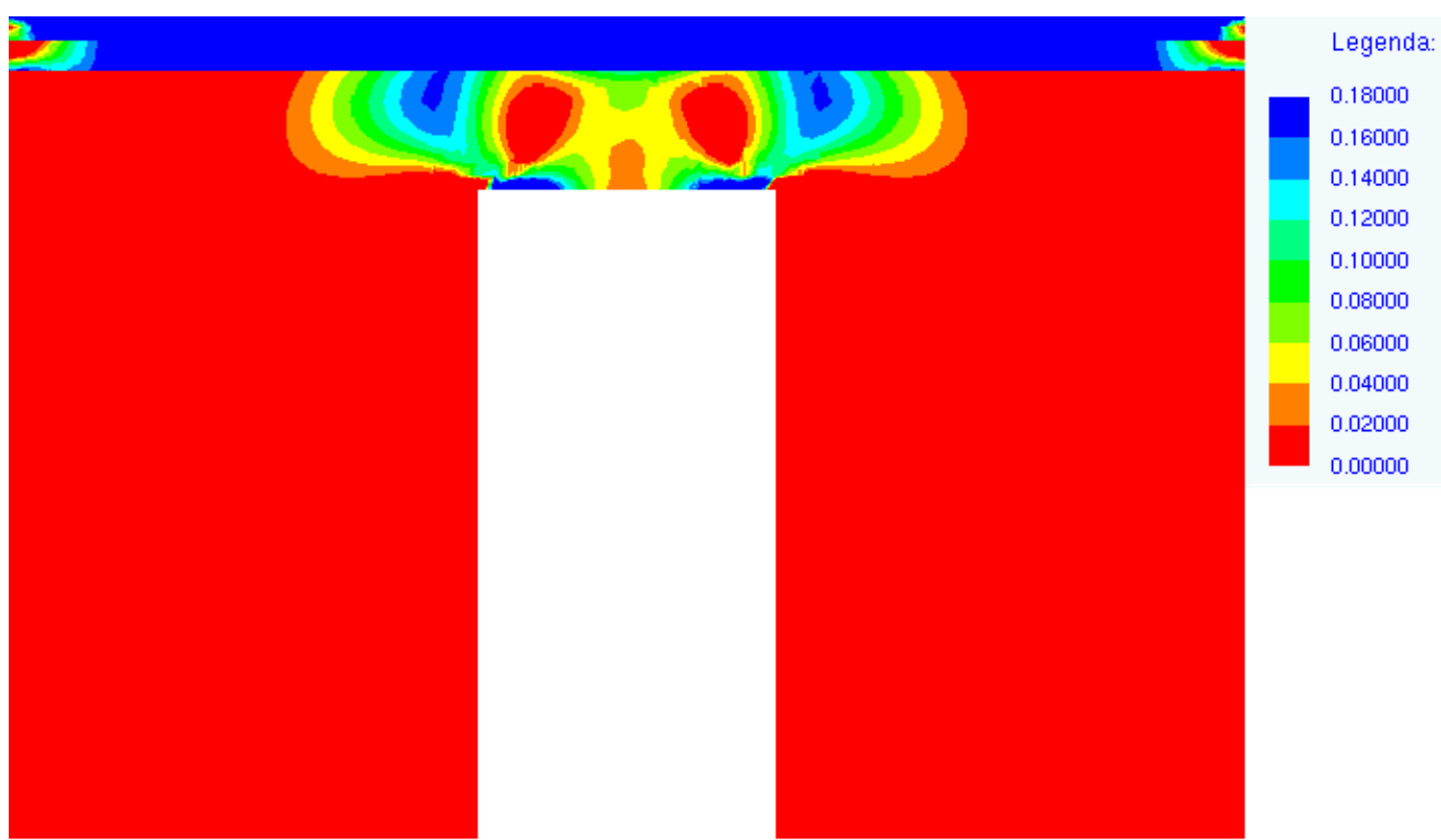

Figura 5.3 - Tensões principais I em painel de parede com abertura de porta sem reforço, com valores entre 0 e $0.18 \mathrm{MPa}$.

\subsubsection{PORTA COM VERGA}

- Tensões principais I, com limite de 0 a $0.30 \mathrm{MPa}$ :

Através do painel da Figura 5.4, pode-se observar que a verga, a laje e a canaleta absorvem a maior parte das tensões de tração. Observa-se ainda que com a inserção da verga, a tensão de tração que anteriormente se apresentava acima da abertura, agora se apresenta ao longo da parte superior da verga, estando presente ainda nas laterais da verga, chegando nesses pontos a valores de até $0.23 \mathrm{MPA}$. 


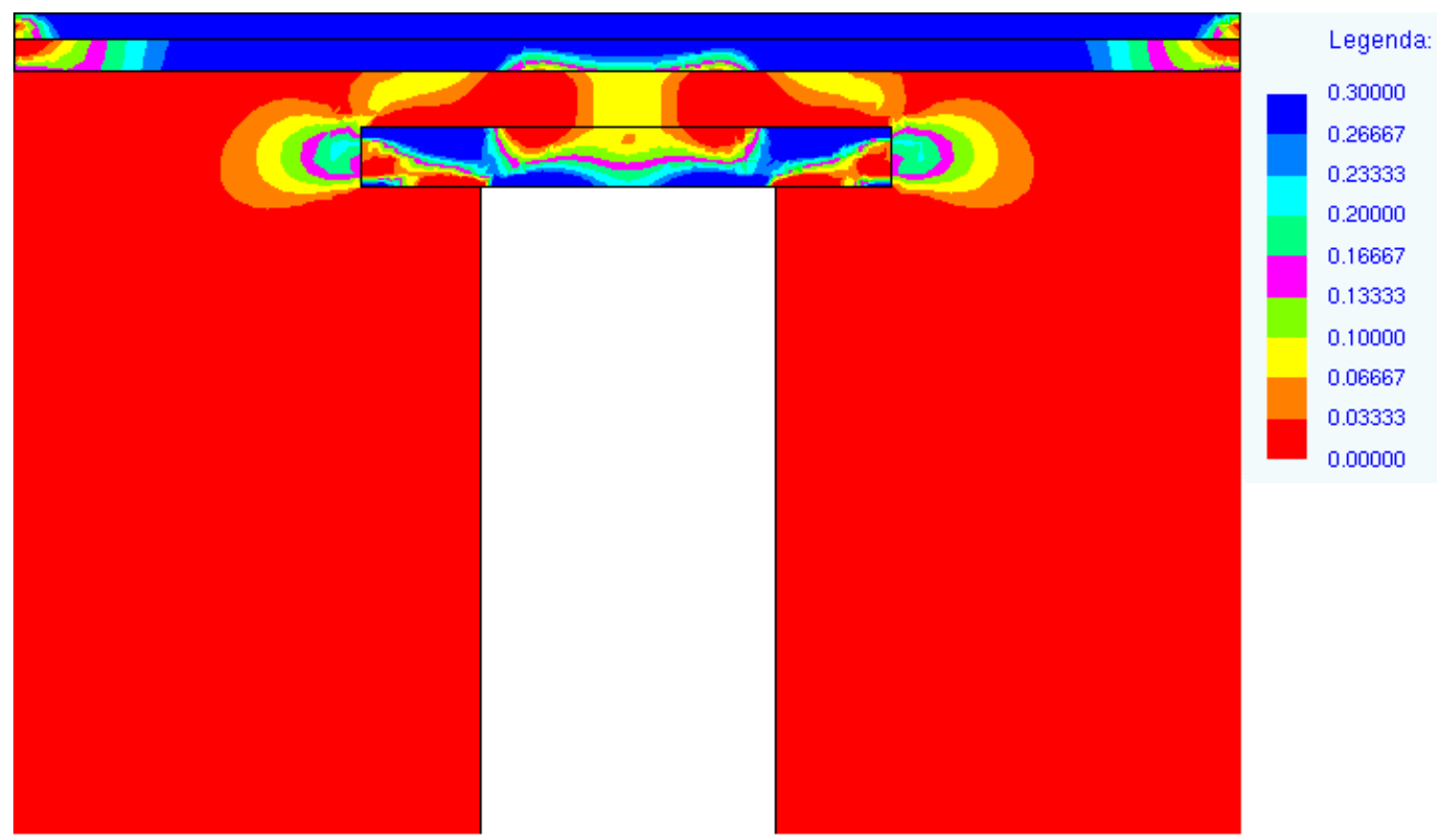

Figura 5.4 - Tensões principais I em painel de parede com abertura de porta com verga, com valores entre 0 e $0.30 \mathrm{MPa}$.

- Tensões principais I, com limite de 0 a $0.18 \mathrm{MPa}$ :

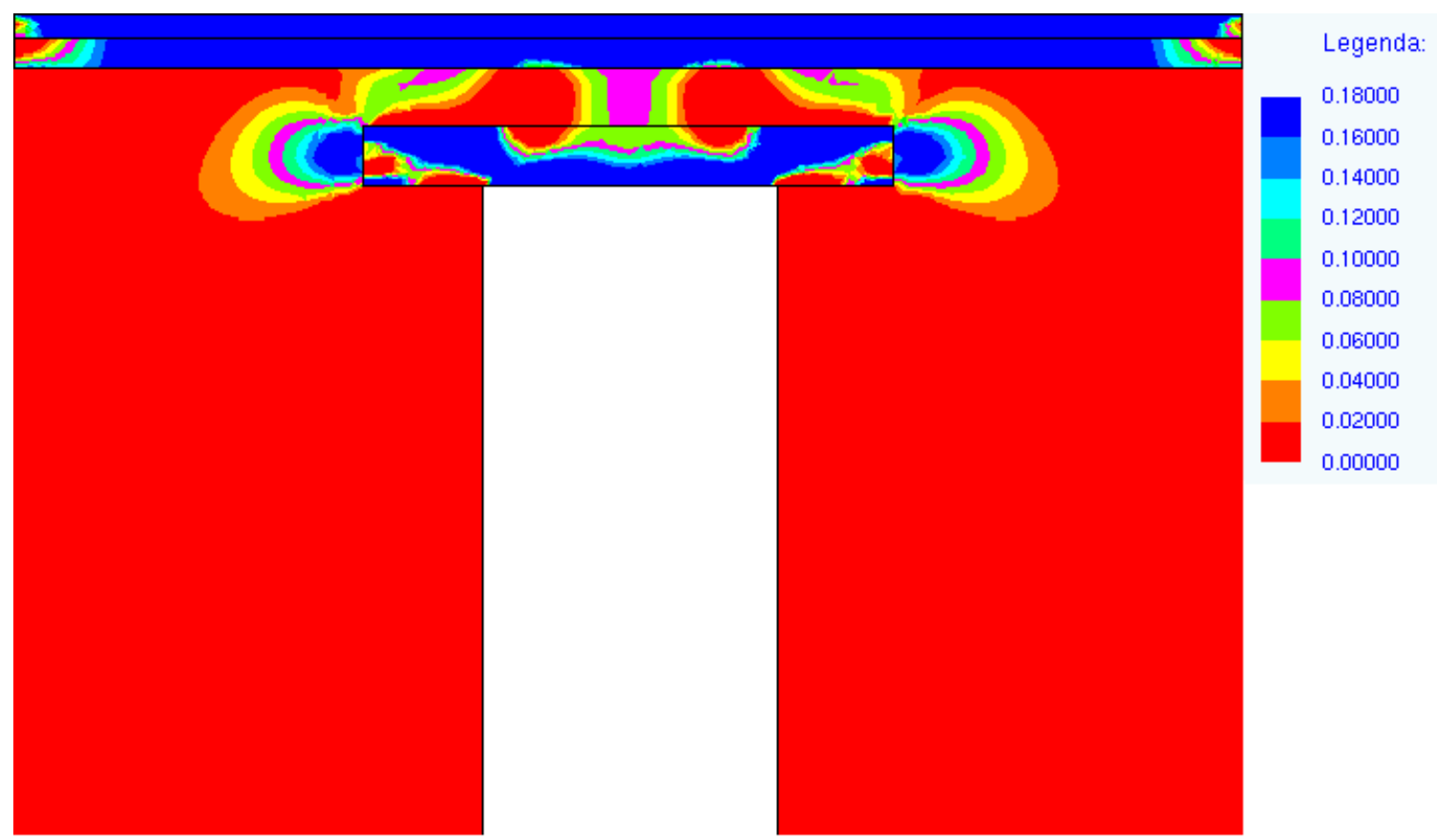

Figura 5.5 - Tensões principais I em painel de parede com abertura de porta com verga, com valores entre 0 e $0.18 \mathrm{MPa}$. 
Alterando os limites de tensão de tração para 0 e $0.18 \mathrm{MPa}$, observamos duas áreas mais concentradas nas laterais da vergas, onde essas tensões ultrapassam o valor de $0.18 \mathrm{MPa}$.

\subsubsection{PORTA COM VERGA E REFORÇOS LATERAIS CURTOS}

- Tensões principais I, com limite de 0 a $0.30 \mathrm{MPa}$ :

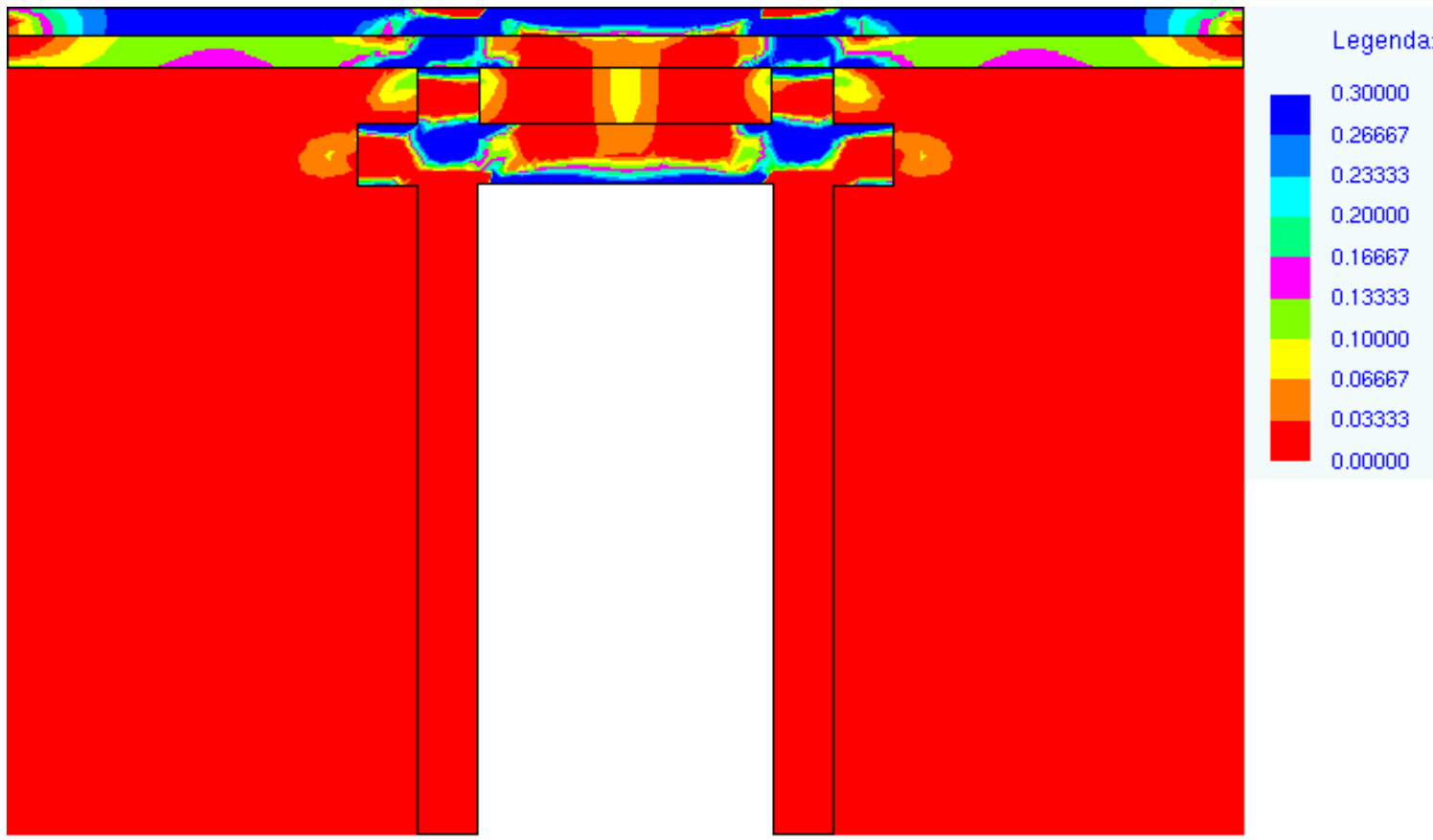

Figura 5.6 - Tensões principais I em painel de parede com abertura de porta com verga, e reforços laterais, com valores entre 0 e $0.30 \mathrm{MPa}$.

Assim como na Figura 5.4, com a inserção do reforço lateral observou-se o aparecimento de novos pontos de concentrações de tensão. No entanto, nesse painel esses pontos surgiram em maior intensidade nas laterais superiores externas dos reforços.

- Tensões principais I, com limite de 0 a $0.18 \mathrm{MPa}$ :

Para uma melhor observação da intensidade da tensão de tração que passou a ocorrer com a inserção dos reforços laterais, optou-se por apresentar os limites entre 0 e 0.18MPa. Dessa forma, observa-se que os valores não ultrapassam os limites permitidos pela Norma, chegando apenas a $0.14 \mathrm{MPa}$. 


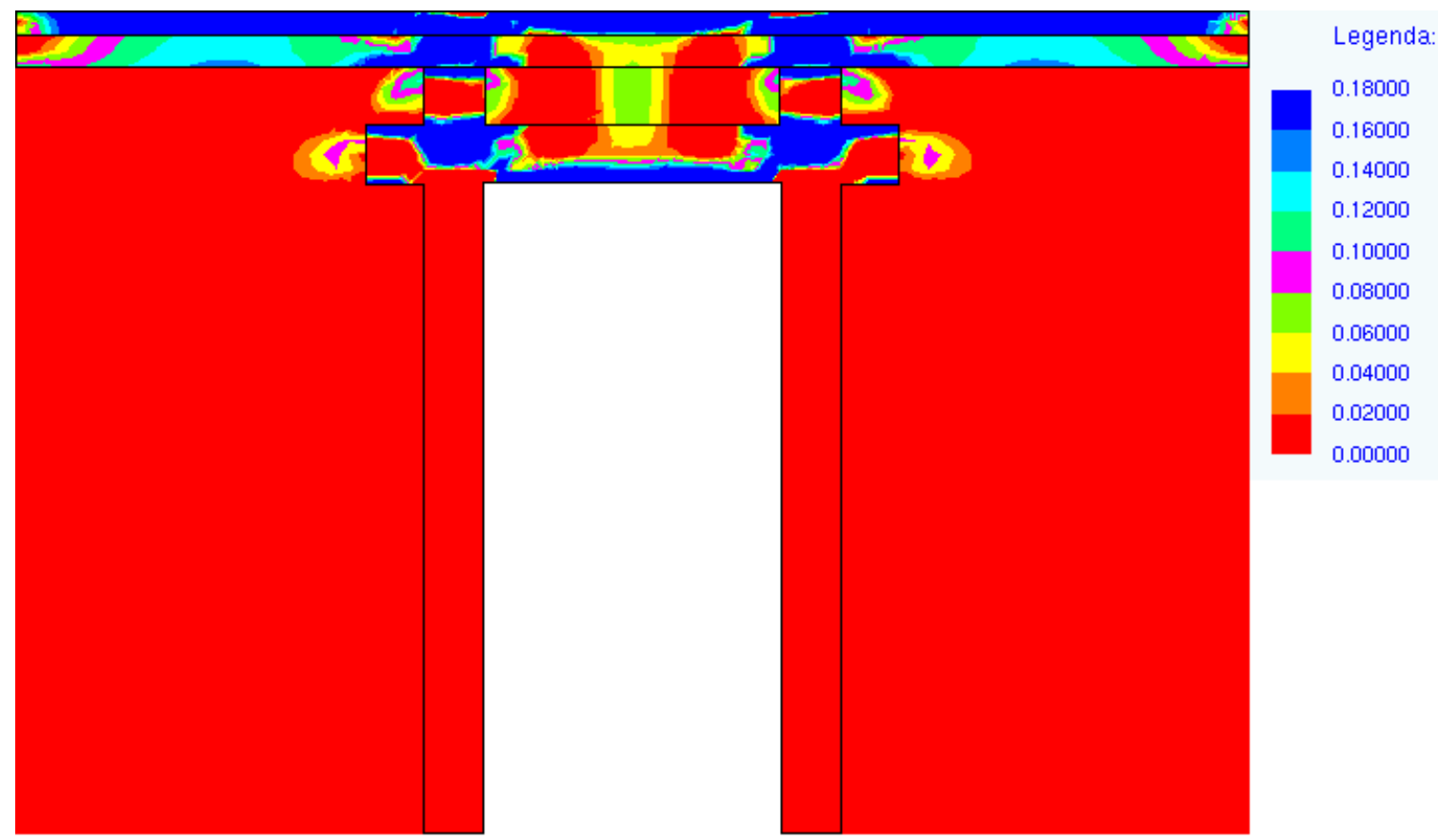

Figura 5.7 - Tensões principais I em painel de parede com abertura de porta com verga, e reforços laterais, com valores entre 0 e $0.18 \mathrm{MPa}$.

\subsection{Painéis COM ABERTURA de JANELA}

\subsubsection{JANELA SEM REFORÇOS}

- Tensões principais I, com limite de 0 a 0.60MPa:

Da mesma forma como foi realizado no item anterior, filtraram-se os resultados com valores entre 0 e $0.60 \mathrm{MPa}$ para uma observação mais precisa de ocorrência de tensão de tração. Com isso pode-se verificar o seu aparecimento na laje e na canaleta, da mesma forma como havia ocorrido nas figuras anteriores, e ainda nas partes superior e inferior da abertura.

Quanto aos valores apresentados nota-se que a tensão de tração na alvenaria é bastante considerável, pois chega a 0.60MPa. Diante disso, as partes superior e inferior da abertura da janela são pontos importantes para a comparação com os demais modelos, visto que essa é uma área favorável ao aparecimento de fissuras.

Da mesma forma que ocorreu no modelo anterior, as laterais das aberturas não apresentam tensões de tração. 


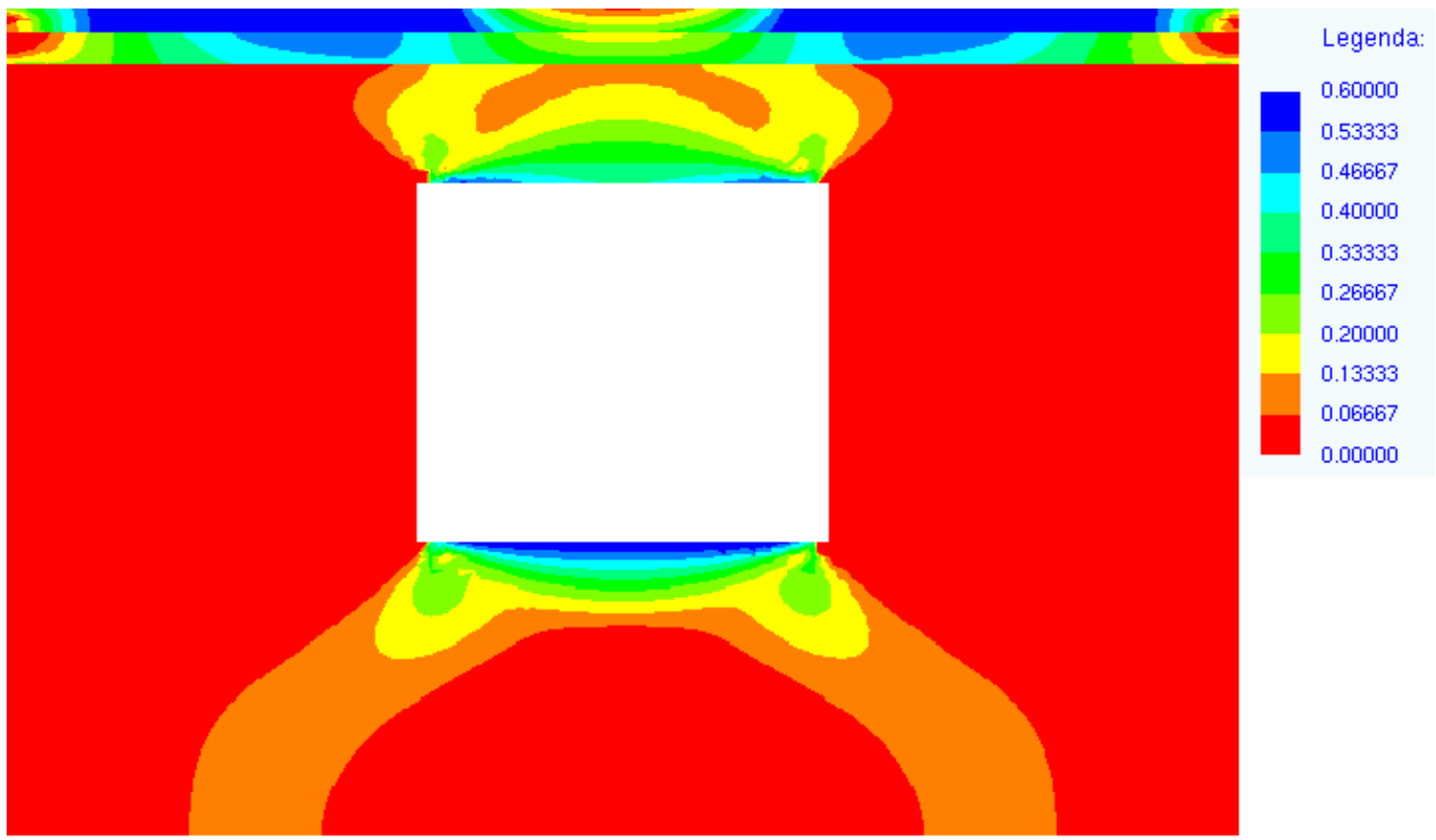

Figura 5.8 - Tensões principais I em painel de parede com abertura de janela sem reforço, com valores entre 0 e $0.60 \mathrm{MPa}$.

- Tensões principais I, com limites entre 0 a $0.40 \mathrm{MPa}$ e 0 e $0.25 \mathrm{MPa}$ :

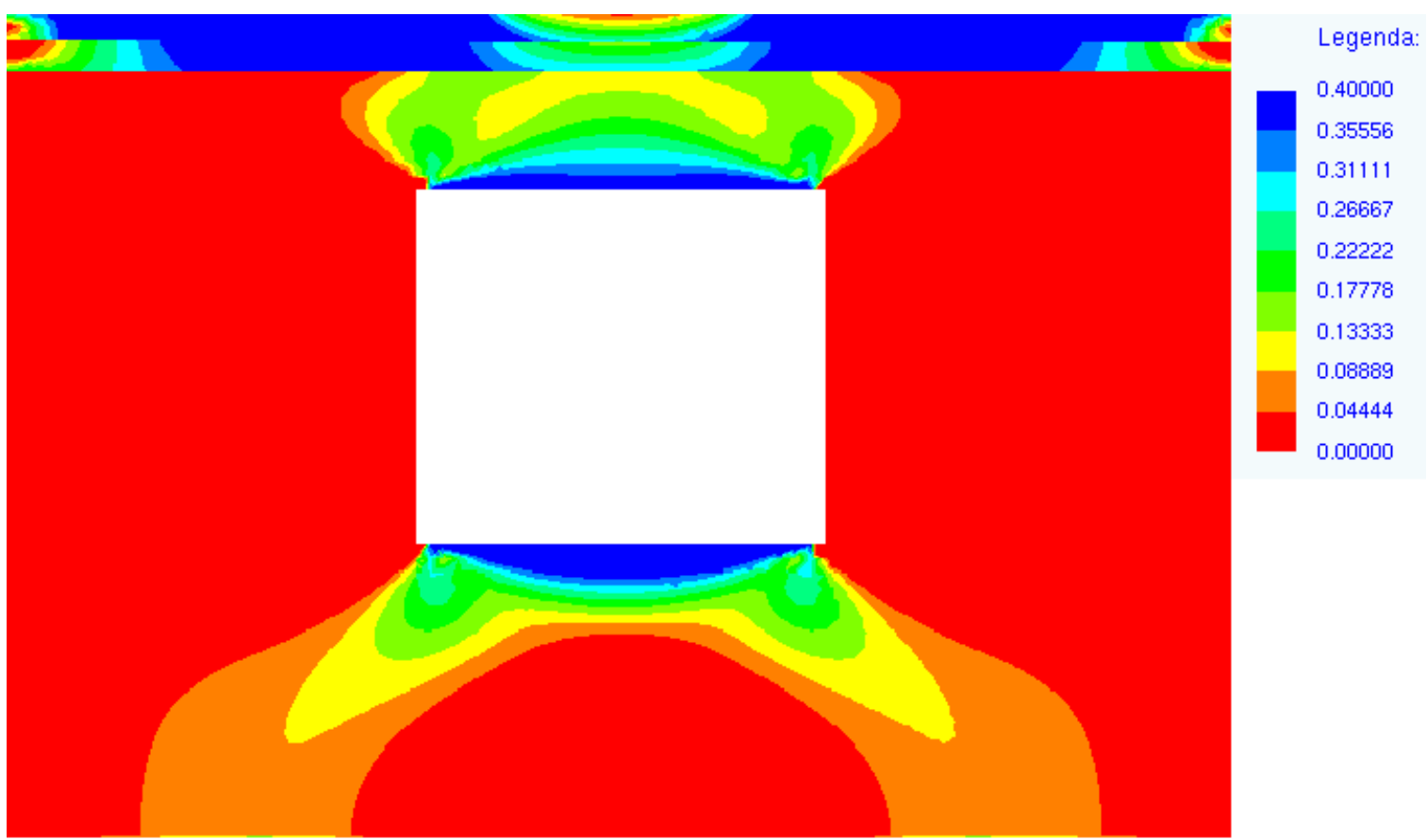

Figura 5.9 - Tensões principais I em painel de parede com abertura de janela sem reforço, com valores entre 0 e $0.40 \mathrm{MPa}$. 
Para uma melhor visualização dos resultados, optou-se por apresentar os resultados com limites mais próximos aos permitidos pela Norma, dessa forma, estão sendo mostrados os resultados com limites entre 0 e $0.40 \mathrm{MPa}$ e entre 0 e $0.25 \mathrm{MPa}$.

Assim como na Figura 5.8, observa-se que nas partes superior e inferior dos vãos ocorrem grandes valores de tensões de tração, e quanto menor no intervalo, maior a área afetada. Como todos os intervalos são bem superiores aos limites permitidos pela Norma, verifica-se que essas são áreas suscetíveis ao aparecimento de fissuras devido à concentração de tensão de tração.

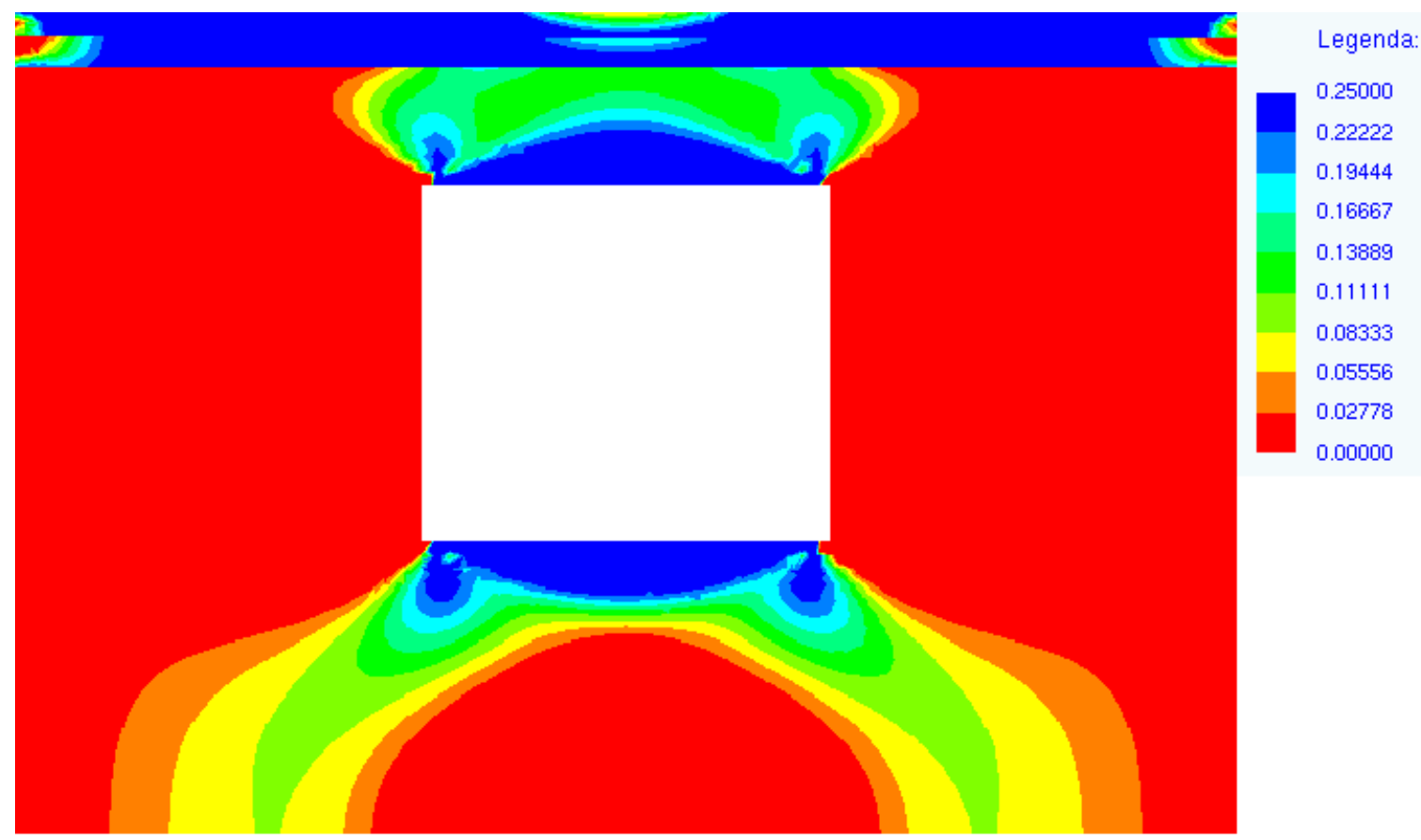

Figura 5.10 - Tensões principais I em painel de parede com abertura de janela sem reforço, com valores entre 0 e $0.25 \mathrm{MPa}$.

\subsubsection{JANELA COM VERGA}

- Tensões principais I, com limite de 0 a $0.60 \mathrm{MPa}$ :

No painel da Figura 5.11 pode-se notar que ocorreu uma concentração de tração muito parecida com a observada na Figura 5.4, onde ocorre um desvio no caminho das tensões de tração devido à utilização da verga. Ela absorve grande parte da tração 
superior, fazendo com que apenas uma parcela alcance a parede em alvenaria. Devido a esse desvio, alguns locais que não apresentavam essas tensões anteriormente, agora estão apresentando, só que em parcela pequena e dentro do limite permitido.

Além disso, podemos notar que sob a janela há uma área grande com altos valores de tensão de tração, da mesma forma que ocorre na Figura 5.8, conforme podemos observar na Figura 5.11, que possui a apresentação com os mesmos limites apresentados na Figura 5.8.

Assim como na Figura 5.4 ocorreu uma transferência da tensão de tração na parte superior da janela para as laterais da verga.

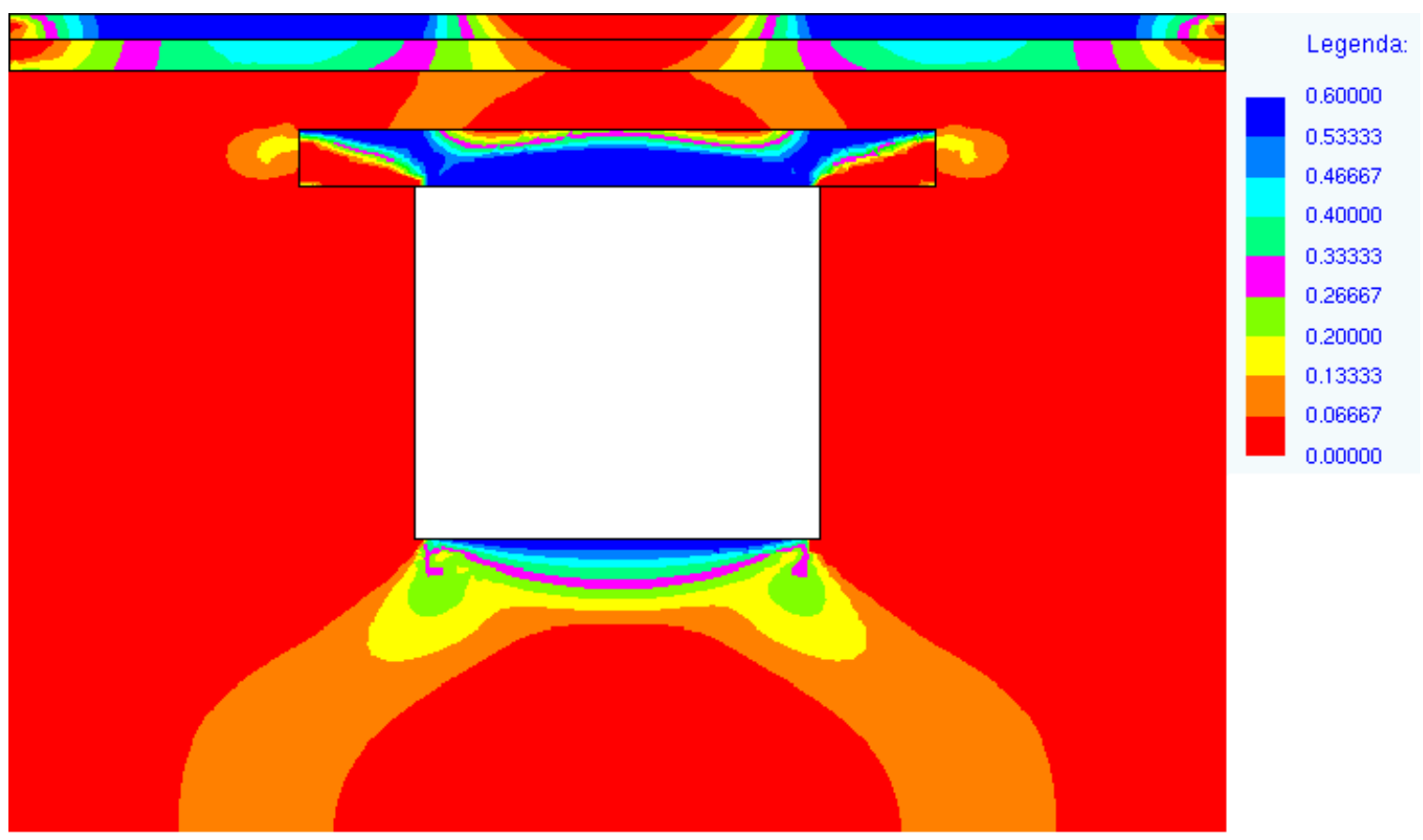

Figura 5.11 - Tensões principais I em painel de parede com abertura de janela com verga, com valores entre 0 e $0.60 \mathrm{MPa}$.

- Tensões principais I, com limites entre 0 a $0.40 \mathrm{MPa}$ e 0 e $0.25 \mathrm{MPa}$ :

Assim como nas Figuras 5.9 e 5.10, para uma melhor visualização dos resultados, optou-se por apresentar os resultados com limites mais próximos aos permitidos pela Norma, dessa forma, estão sendo mostrados os resultados com limites entre 0 e $0.40 \mathrm{MPa}$ e entre 0 e $0.25 \mathrm{MPa}$. 


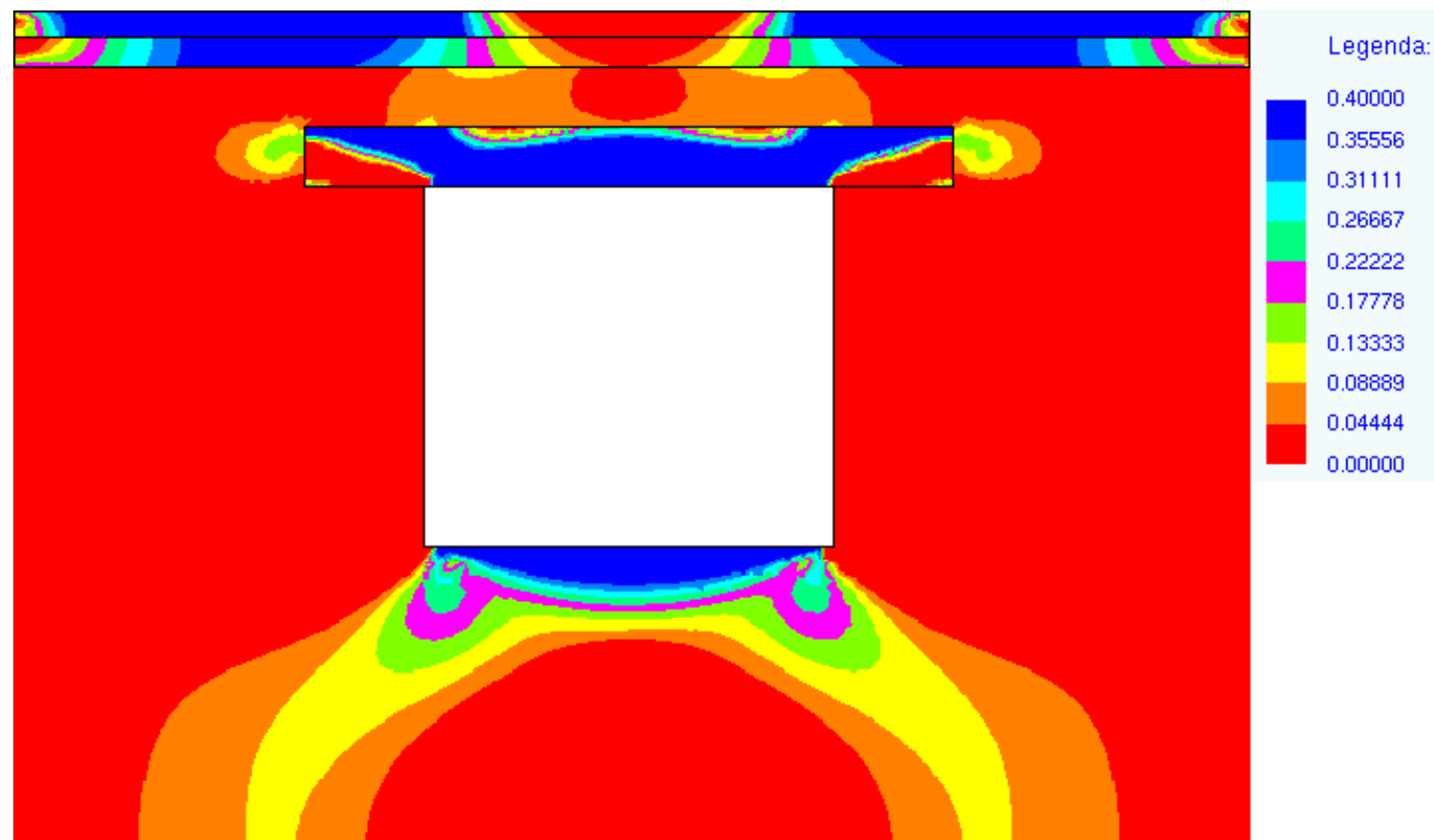

Figura 5.12 - Tensões principais I em painel de parede com abertura de janela com verga, com valores entre 0 e $0.60 \mathrm{MPa}$.

Assim como na Figura 5.11, observa-se que nas partes inferiores dos vãos ocorrem grandes valores de tensões de tração, e quanto menor no intervalo da tensão de tração, maior a área afetada.

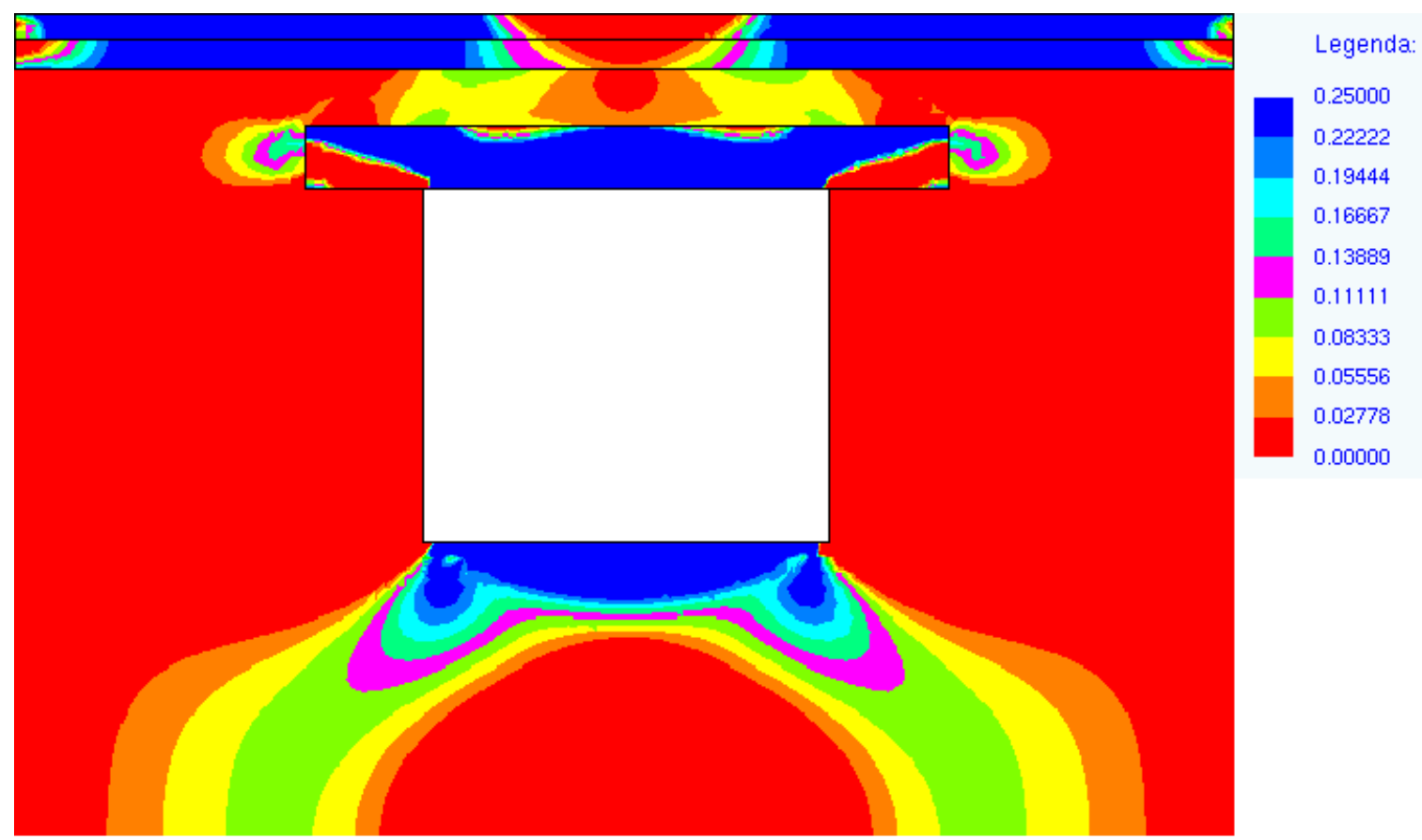

Figura 5.13 - Tensões principais I em painel de parede com abertura de janela com verga, com valores entre 0 e $0.60 \mathrm{MPa}$. 
Com a redução dos limites observam-se que os valores transmitidos nas laterais das vergas para a alvenaria, chegam a $0.17 \mathrm{MPa}$.

\subsubsection{JANELA COM VERGA E CONTRAVERGA}

- Tensões principais I, com limite de 0 a $0.60 \mathrm{MPa}$ :

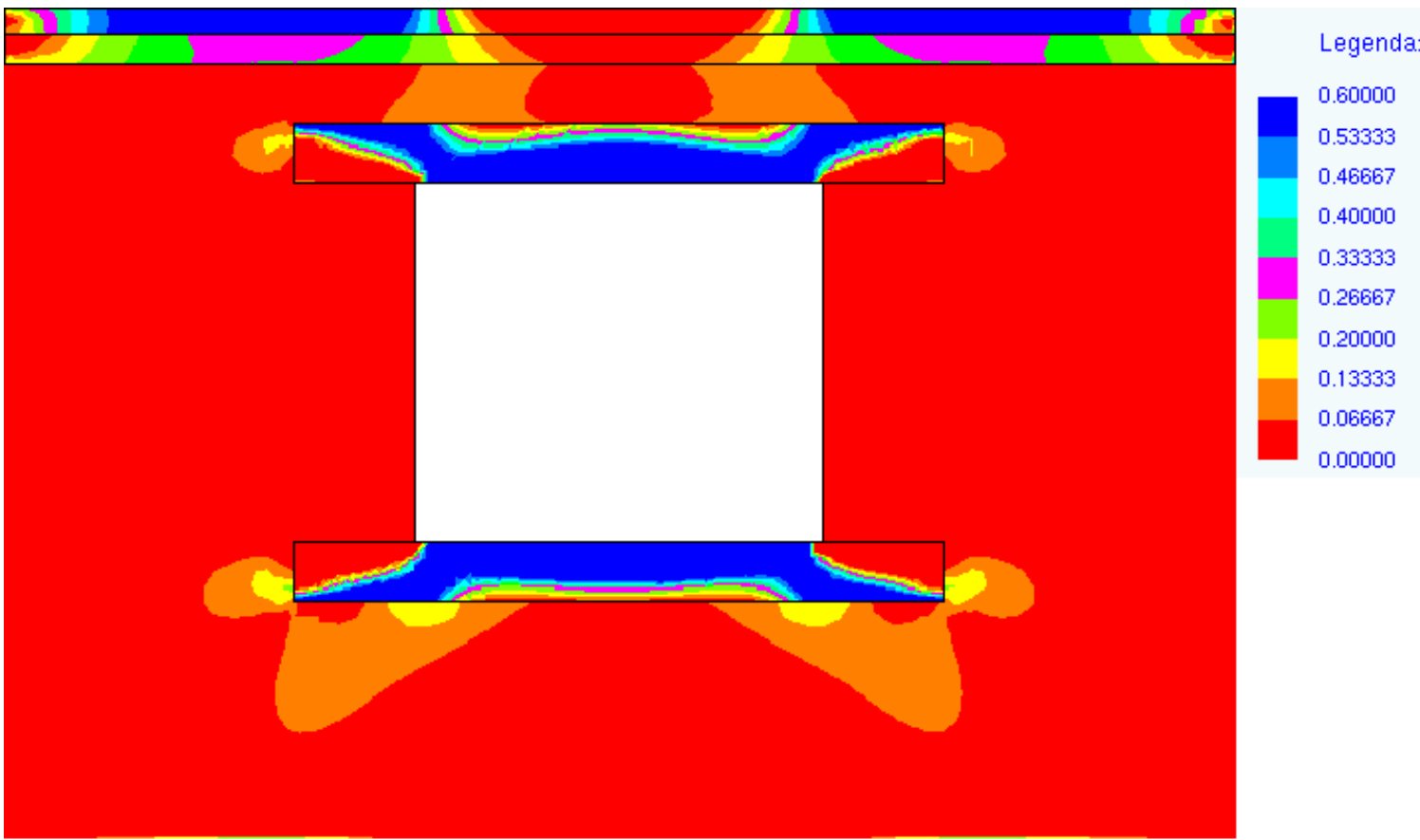

Figura 5.14 - Tensões principais I em painel de parede com abertura de janela com verga e contraverga, com valores entre 0 e $0.60 \mathrm{MPa}$.

Assim como foi observado nas Figuras 5.11, 5.12 e 5.13, onde a verga absorve grande parte da tensão de tração na parte superior, no painel da Figura 5.14 pode-se observar que a contraverga absorve parte da tensão de tração na parte inferior, com isso a alvenaria sofre menos com tensões de tração. No entanto, de acordo com os valores apresentados, continua sendo transferida uma parcela significativa para a parede em alvenaria.

- Tensões principais I, com limites entre 0 a $0.40 \mathrm{MPa}$ e 0 e $0.25 \mathrm{MPa}$ :

Com a redução dos limites das variações de tensões de tração observa-se que mesmo com a inserção das vergas e contravergas, ocorrem transmissões com valores de 
até $0.19 \mathrm{MPa}$ para a parede em alvenaria, tanto nas partes inferiores das contravergas quanto nas laterais das vergas.

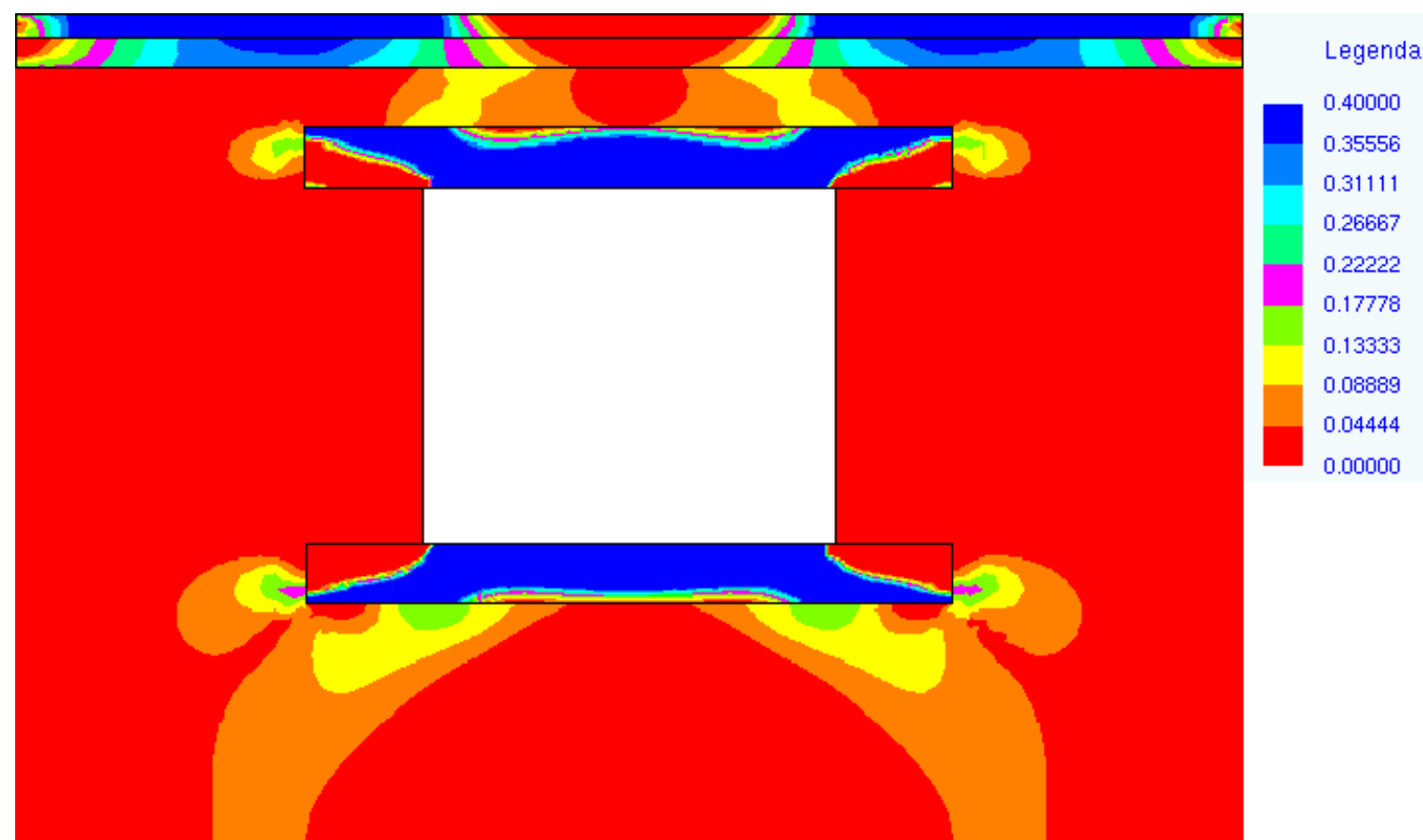

Figura 5.15 - Tensões principais I em painel de parede com abertura de janela com verga e contraverga, com valores entre 0 e $0.40 \mathrm{MPa}$.

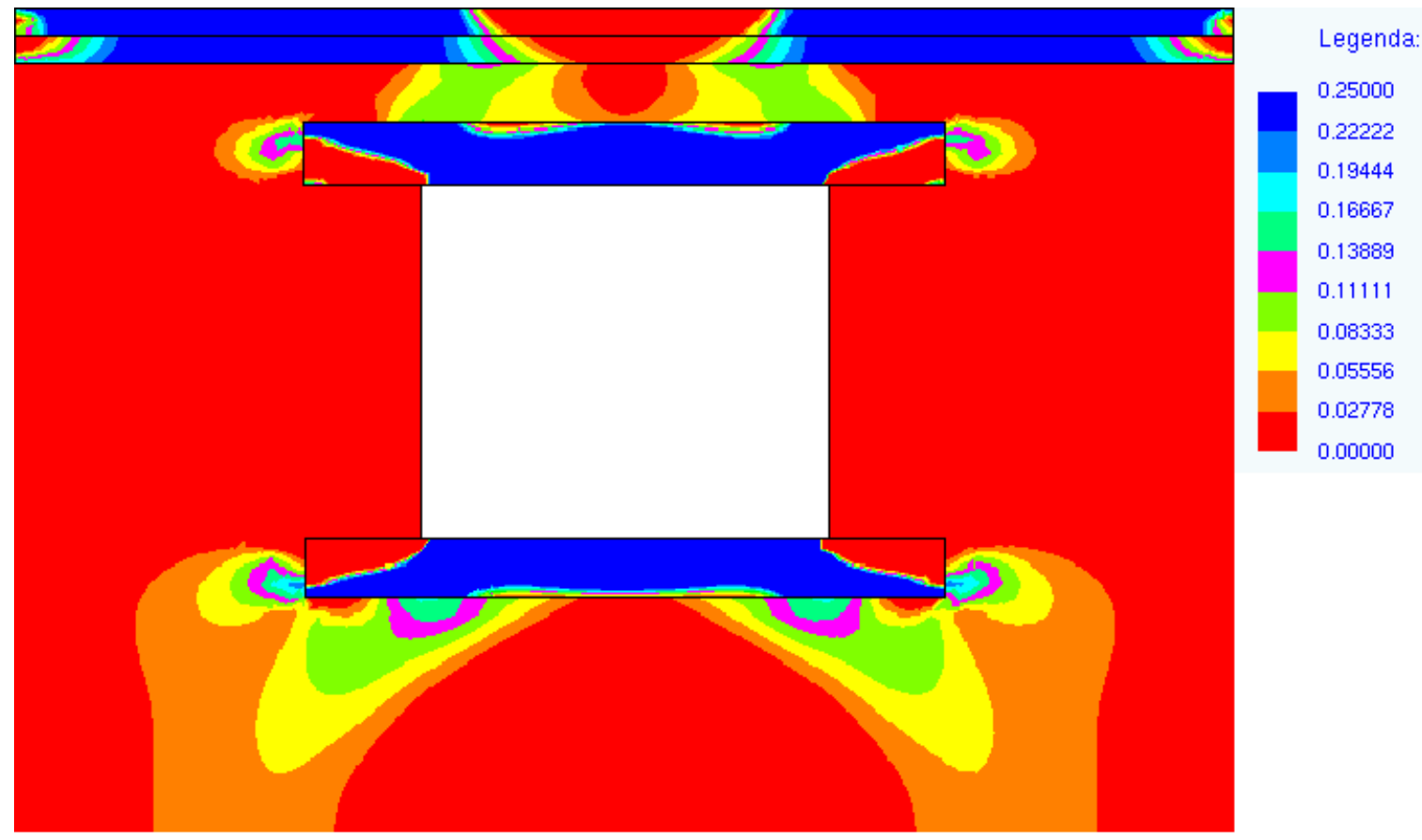

Figura 5.16 - Tensões principais I em painel de parede com abertura de janela com verga e contraverga, com valores entre 0 e $0.25 \mathrm{MPa}$. 


\subsubsection{JANELA COM VERGA, CONTRAVERGA E REFORÇOS LATERAIS CURTOS}

- Tensões principais I, com limite de 0 a $0.60 \mathrm{MPa}$ :

Como já havia sido observado, nas figuras de paredes com aberturas de portas apresentadas anteriormente, não ocorreu o aparecimento de tensões de tração nas laterais das aberturas de janelas. No entanto, optou-se por realizar uma modelagem acrescentando-se além das vergas e contravergas, reforços laterais curtos, com a finalidade de verificar em que esse reforço poderia influenciar.

Assim como ocorreu nas Figuras 5.6 e 5.7, com a inserção dos reforços laterais verifica-se o aparecimento de uma concentração de tensão de tração em pontos onde não apareciam anteriormente, sendo que neste caso esses pontos ocorrem entre os encontros internos dos reforços com a verga assim como dos reforços com a contraverga, e no caso da Figura 5.17, esses pontos ocorreram nos encontros externos.

Na Figura 5.17 pode-se observar que em alguns pontos esses valores de tensões de tração chegam a 0.40MPa, o que é considerado muito significativo.

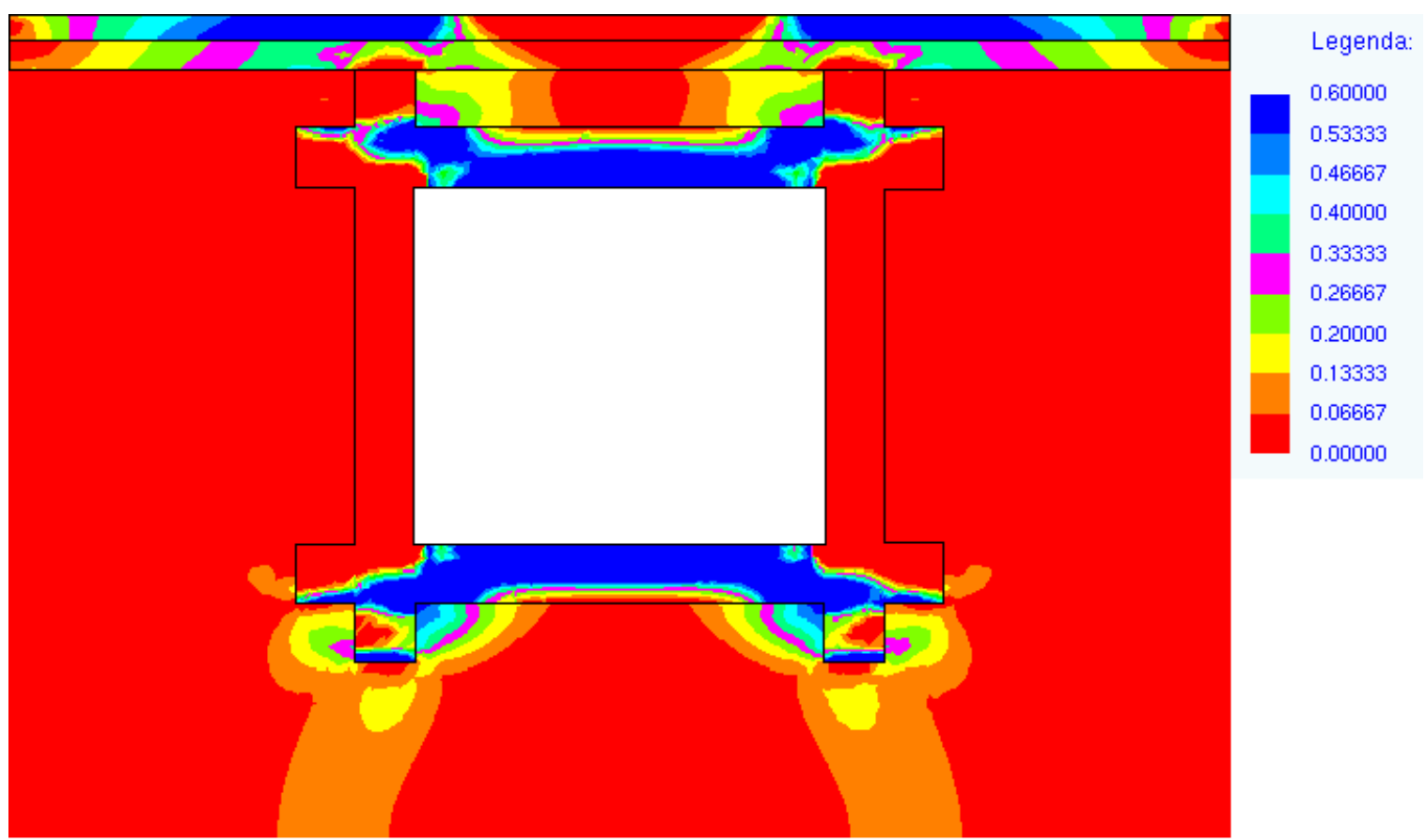

Figura 5.17 - Tensões principais I em painel de parede com abertura de janela com verga, contraverga e reforços laterais curtos, com valores entre 0 e $0.60 \mathrm{MPa}$. 
- Tensões principais I, com limites entre 0 a $0.40 \mathrm{MPa}$ e 0 e $0.25 \mathrm{MPa}$ :

Com a redução dos limites das variações de tensões de tração observa-se que mesmo com a inserção dos reforços laterais, ocorrem transmissões com valores superiores a 0.40MPa para a parede em alvenaria, tanto nas partes inferiores das contravergas quanto nas laterais das vergas.

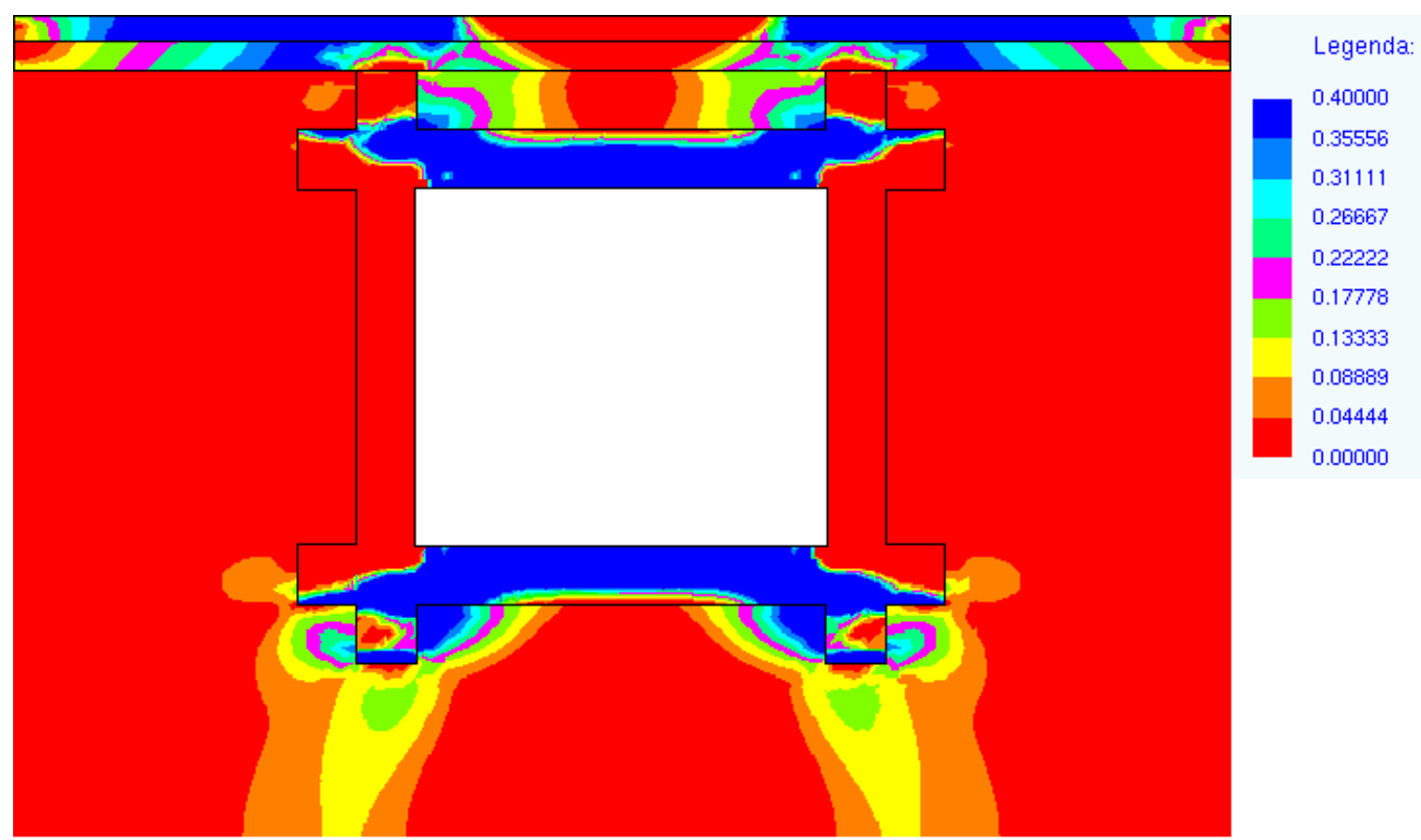

Figura 5.18 - Tensões principais I em painel de parede com abertura de janela com verga, contraverga e reforços laterais curtos, com valores entre 0 e $0.40 \mathrm{MPa}$.

Com a redução do limite para os valores de 0 a $0.25 \mathrm{MPa}$, a área de ocorrência de tensão de tração superior ao valor de $0.25 \mathrm{MPa}$ é muito grande quando comparada com a área de $0.40 \mathrm{MPa}$, o que implica dizer que existe em grande parte desses encontros o valor ultrapassa o valor de $0.25 \mathrm{MPa}$, chegando a ultrapassar $0.40 \mathrm{MPa}$, sendo assim valores muito altos baseados com os limites permitidos pela Norma. 


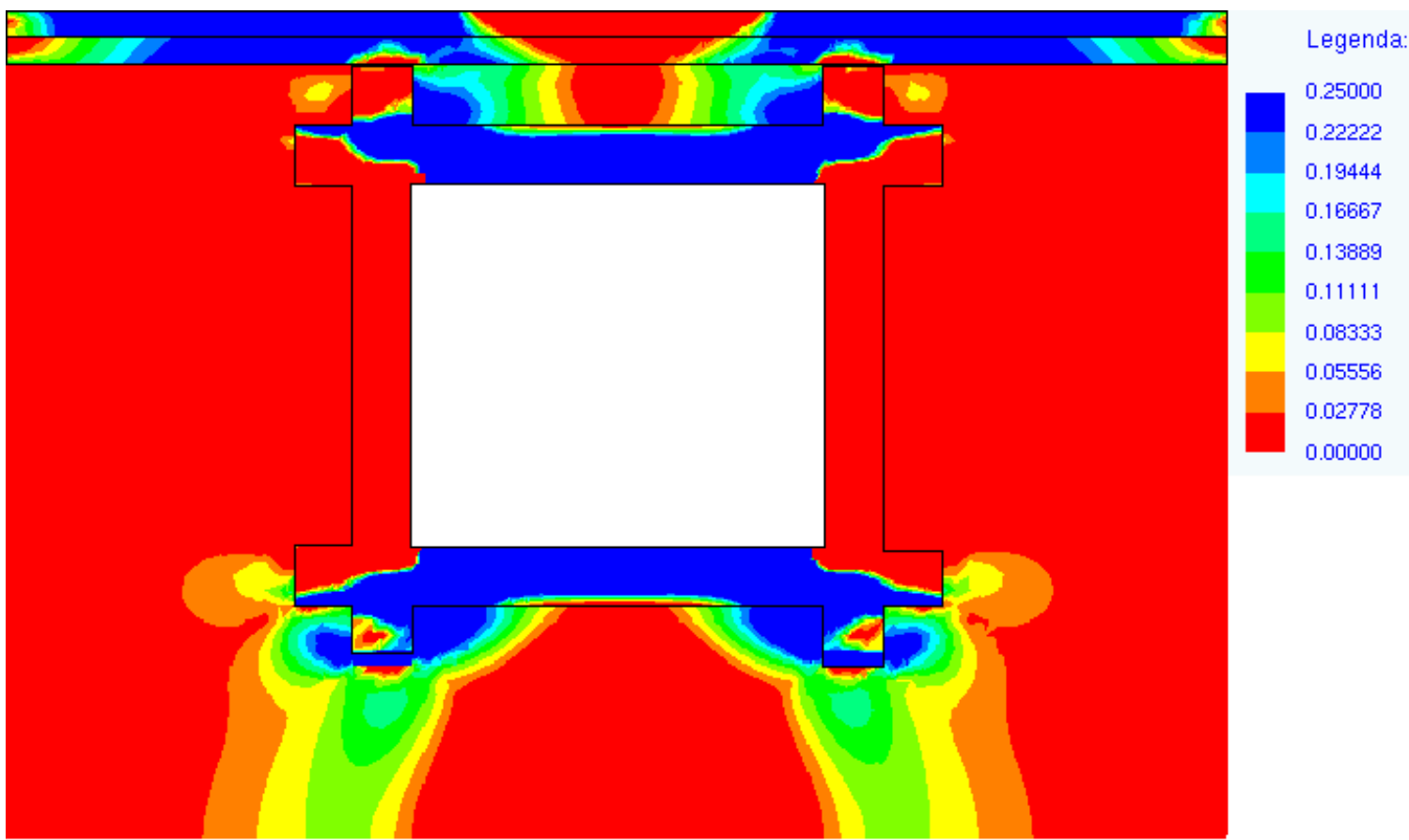

Figura 5.19 - Tensões principais I em painel de parede com abertura de janela com verga, contraverga e reforços laterais curtos, com valores entre 0 e $0.25 \mathrm{MPa}$.

\subsubsection{JANELA COM VERGA, CONTRAVERGA E REFORÇOS LATERAIS LONGOS}

- Tensões principais I, com limite de 0 a $0.60 \mathrm{MPa}$ :

Pelos resultados do painel da Figura 5.20, pode-se observar que o comprimento dos reforços influencia na transmissão das tensões de tração, visto que apesar da configuração ocorrer da mesma forma, entre os encontros internos dos reforços com a verga assim como dos reforços com a contraverga, os valores apresentados são inferiores aos do painel da Figura 5.17, o que não implica dizer que sejam insignificantes, visto que em alguns pontos é superior a $0.33 \mathrm{MPa}$. 


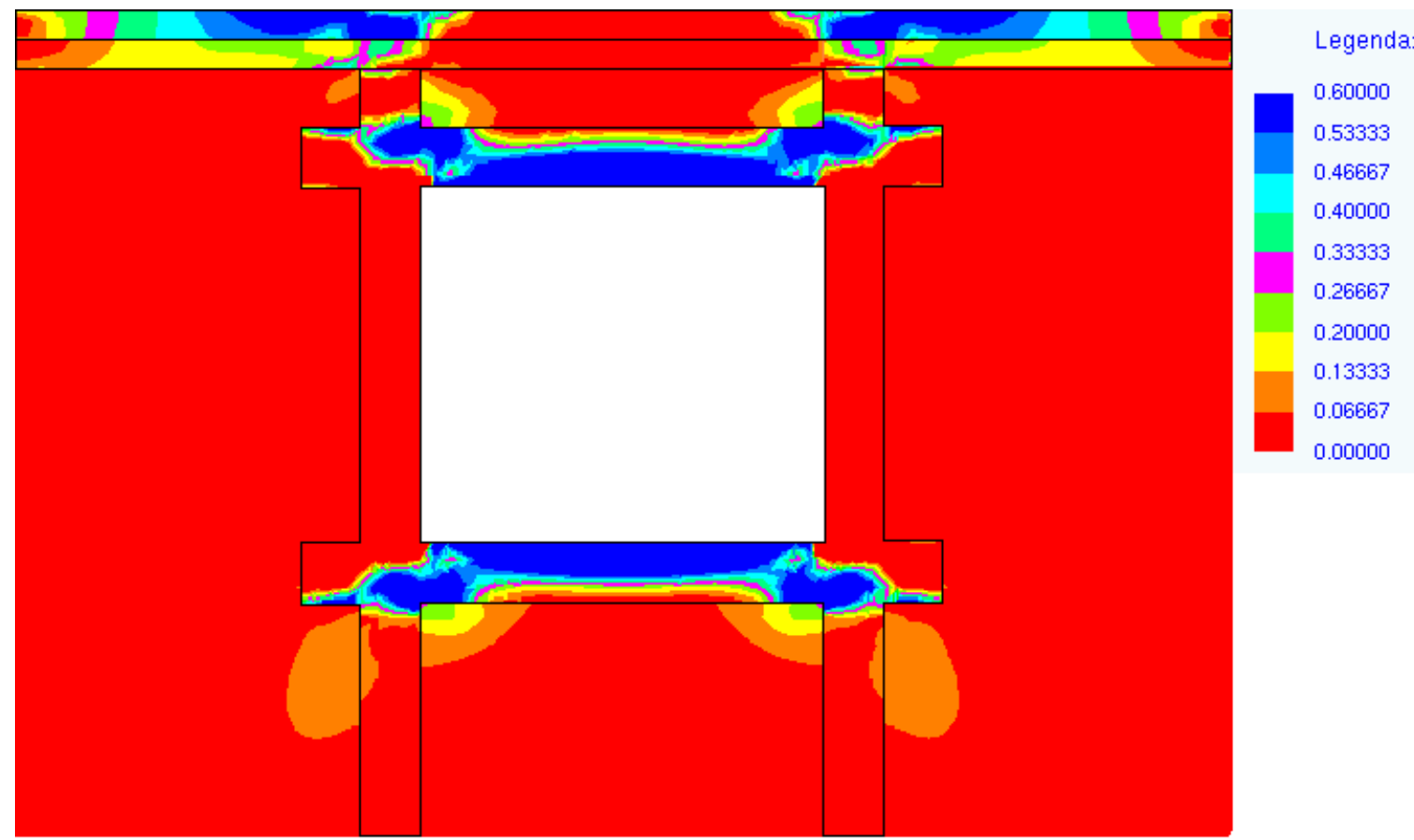

Figura 5.20 - Tensões principais I em painel de parede com abertura de janela com verga, contraverga e reforços laterais longos, com valores entre 0 e $0.60 \mathrm{MPa}$.

- Tensões principais I, com limites entre 0 a $0.40 \mathrm{MPa}$ e 0 e $0.25 \mathrm{MPa}$ :

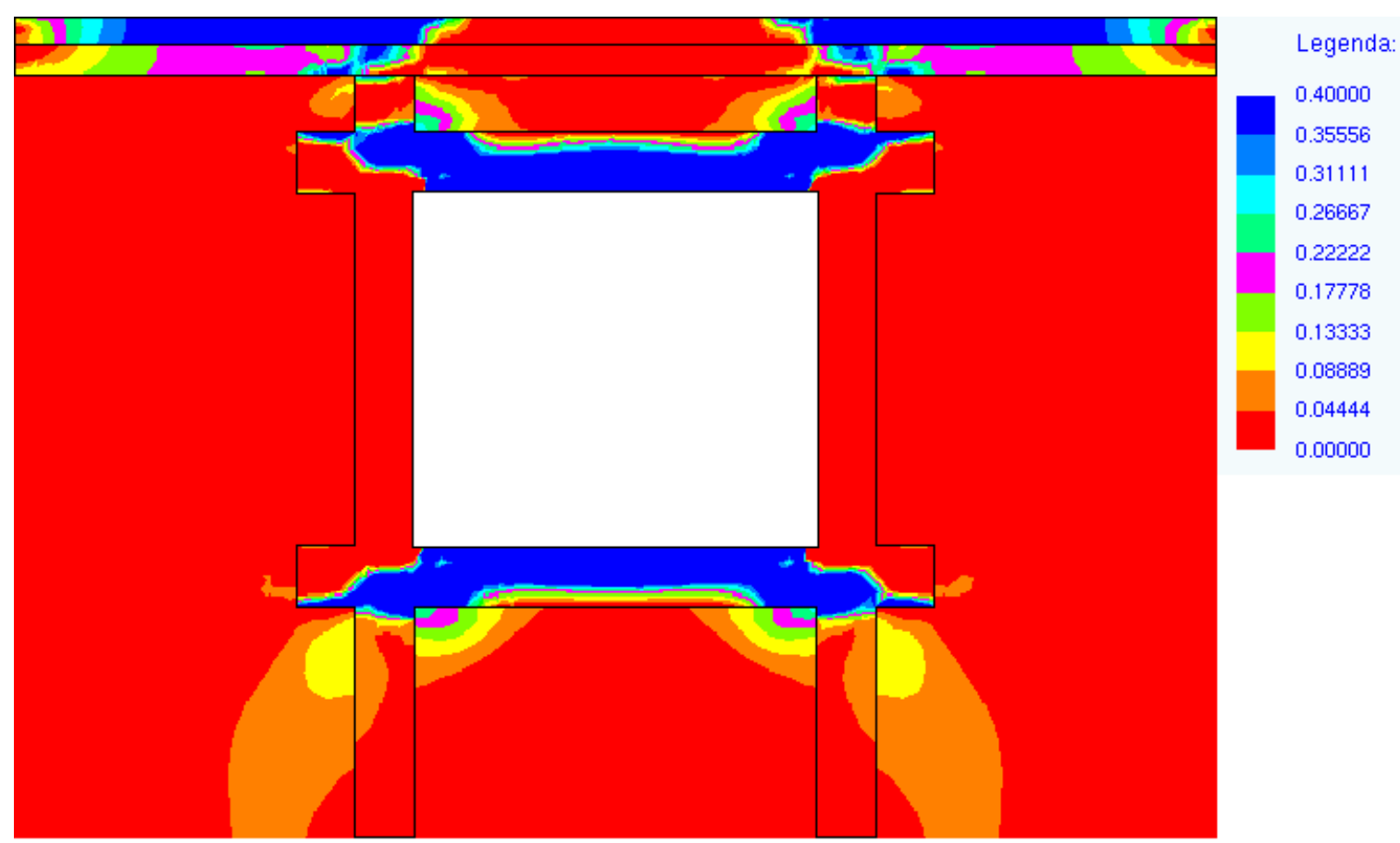

Figura 5.21 - Tensões principais I em painel de parede com abertura de janela com verga, contraverga e reforços laterais longos, com valores entre 0 e $0.40 \mathrm{MPa}$. 
Com a redução dos limites de tensões de tração, verifica-se que os valores transmitidos à parede em alvenaria estrutural nos encontros entre os reforços chegam a $0.26 \mathrm{MPa}$.

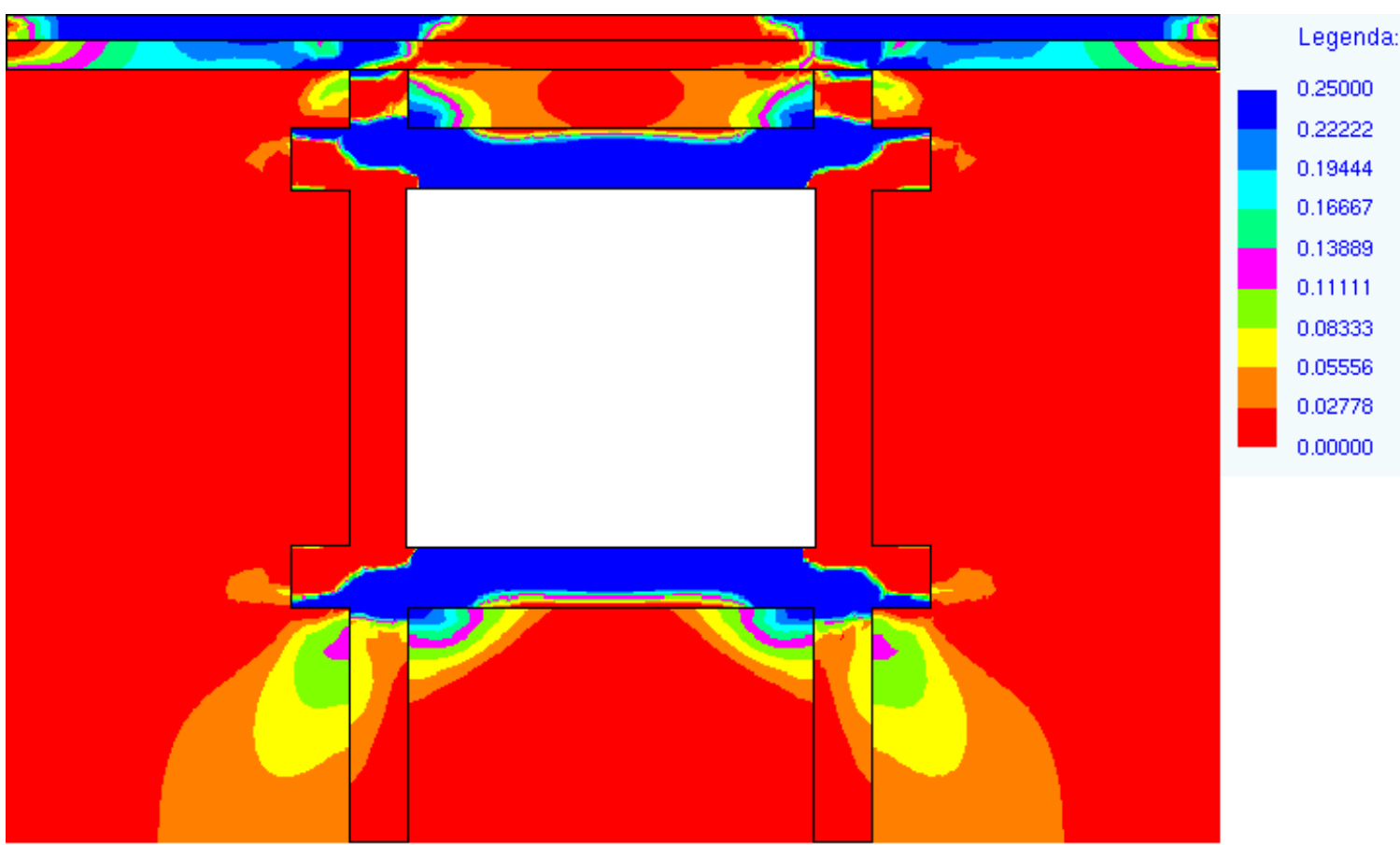

Figura 5.22 - Tensões principais I em painel de parede com abertura de janela com verga, contraverga e reforços laterais longos, com valores entre 0 e $0.25 \mathrm{MPa}$.

\subsubsection{JANELA COM VERGA E CINTA À MEIA ALTURA DA PAREDE}

- Tensões principais I, com limite de 0 a 0.60MPa:

O painel da Figura 5.23 possui verga e em substituição a contraverga utiliza-se uma cinta à meia altura da parede. Nesse caso, observa-se uma configuração de tensões de tração muito parecida com a da Figura 5.14 - Janelas com vergas e contravergas, onde na parte abaixo da cinta são observados valores de tração que chegam a ultrapassar $0.20 \mathrm{MPa}$. 


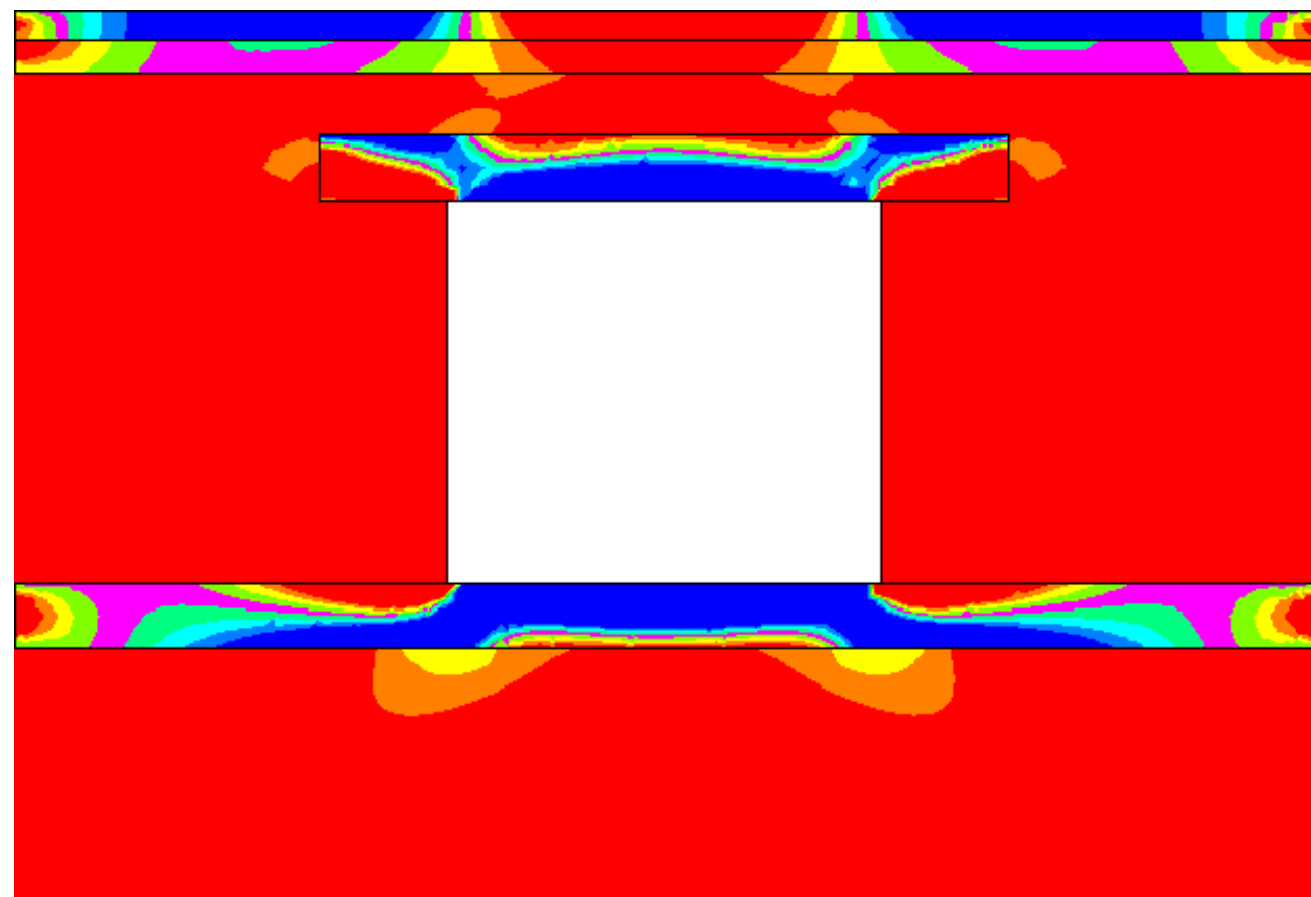

Figura 5.23 - Tensões principais I em painel de parede com abertura de janela com verga, cinta à meia altura da parede, com valores entre 0 e $0.60 \mathrm{MPa}$.

- Tensões principais I, com limites entre 0 a $0.40 \mathrm{MPa}$ e 0 e $0.25 \mathrm{MPa}$ :

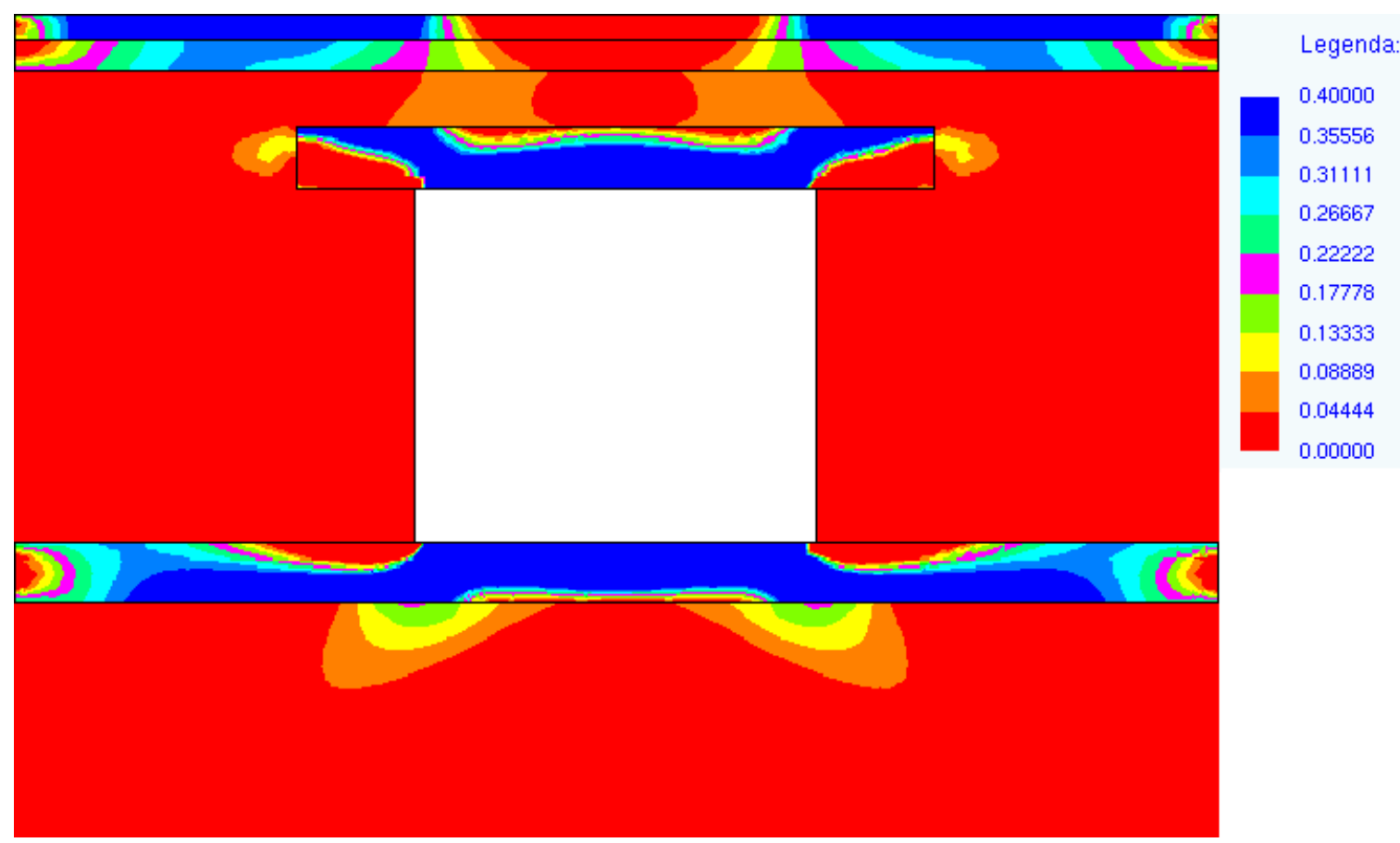

Figura 5.24 - Tensões principais I em painel de parede com abertura de janela com verga, cinta à meia altura da parede, com valores entre 0 e $0.40 \mathrm{MPa}$. 
Com a redução dos limites, consegue-se uma melhor visualização dos resultados, que mostram quem na região próxima a verga, a transmissão das tensões de tração são inferior a $0.13 \mathrm{MPa}$, e na parte inferior da cinta à meia altura elas chegam a $0.19 \mathrm{MPa}$.

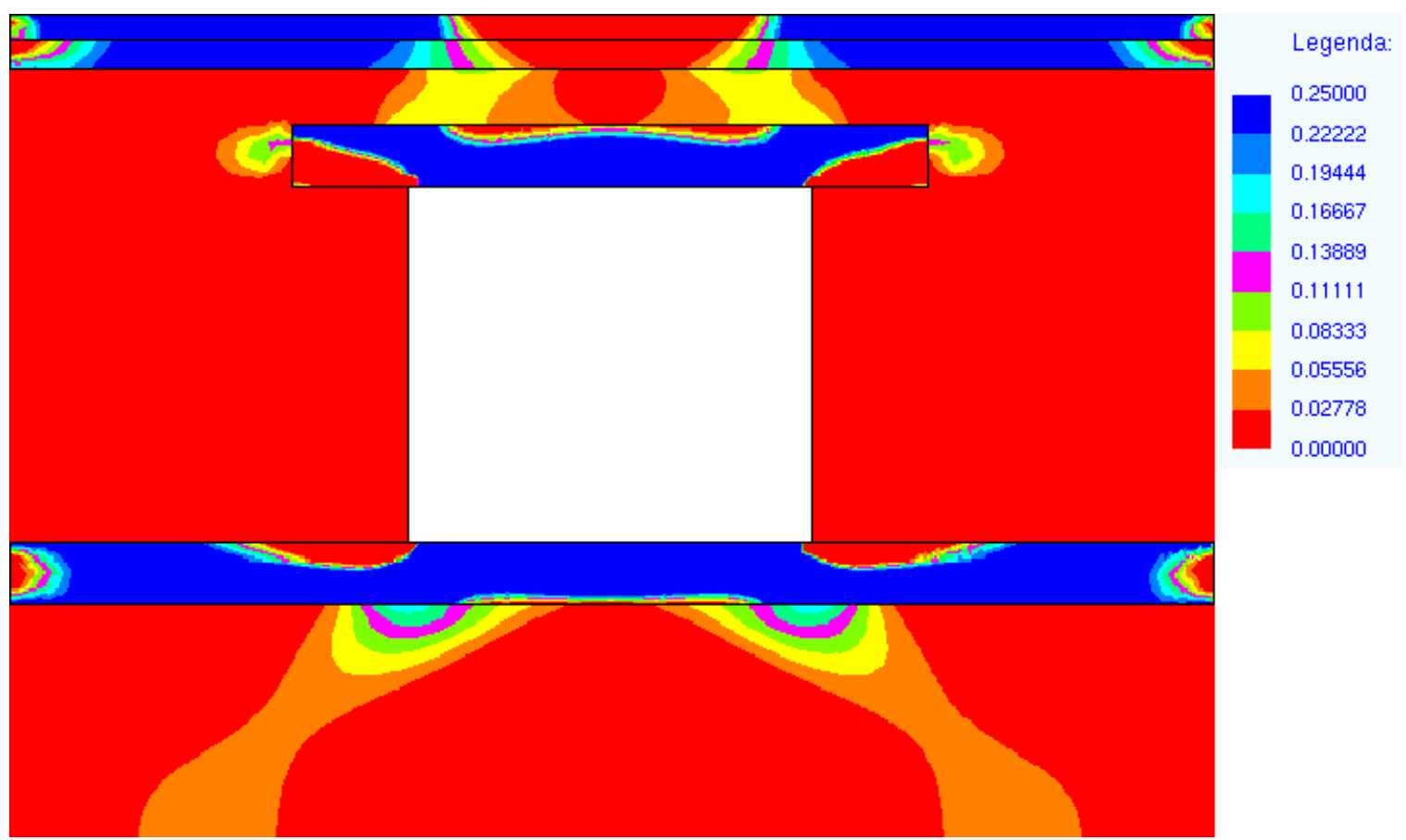

Figura 5.25 - Tensões principais I em painel de parede com abertura de janela com verga, cinta à meia altura da parede, com valores entre 0 e $0.25 \mathrm{MPa}$.

\subsubsection{PAINÉIS MODIFICADOS}

Como se pode notar nos resultados dos painéis com aberturas de janelas, mesmo com a inserção de verga, contraverga e/ou reforços laterais ocorreu o aparecimento de tensões de tração na alvenaria superiores ao permitido pela Norma. Diante disso, optou-se por realizar algumas modificações em modelos com resultados considerados mais próximos do ideal, como é o caso das Figuras 5.14 e 5.23, visando encontrar um modelo que transmitisse tensões de tração para a alvenaria apenas até os limites permitidos pela Norma ou bem próximos a eles.

Diante do exposto, seguem abaixo dois novos painéis: 


\subsubsection{JANELA COM VERGA DE 20 CM DE ALTURA E CONTRAVERGA COM 40 CM DE ALTURA}

- Tensões principais I, com limite de 0 a $0.20 \mathrm{MPa}$ :

Diante do resultado observado nas Figuras 5.14, 5.15 e 5.16, optou-se por fazer um teste modificando a altura da contraverga visando verificar a influência que isso poderia trazer. Para isso utilizou-se uma contraverga com altura equivalente a altura de dois blocos, ou seja, $40 \mathrm{~cm}$.

Como se pode notar na Figura 5.13, ocorreu uma modificação no caminhamento das tensões de tração, visto que na parte inferior do vão da janela elas não foram transmitidas para a alvenaria como anteriormente, sendo transmitidos apenas valores bem abaixo do limite permitido pela Norma.

Pode-se observar ainda uma área muito pequena de transmissão de tensão de tração um pouco superior a esse limite na parte superior da verga.

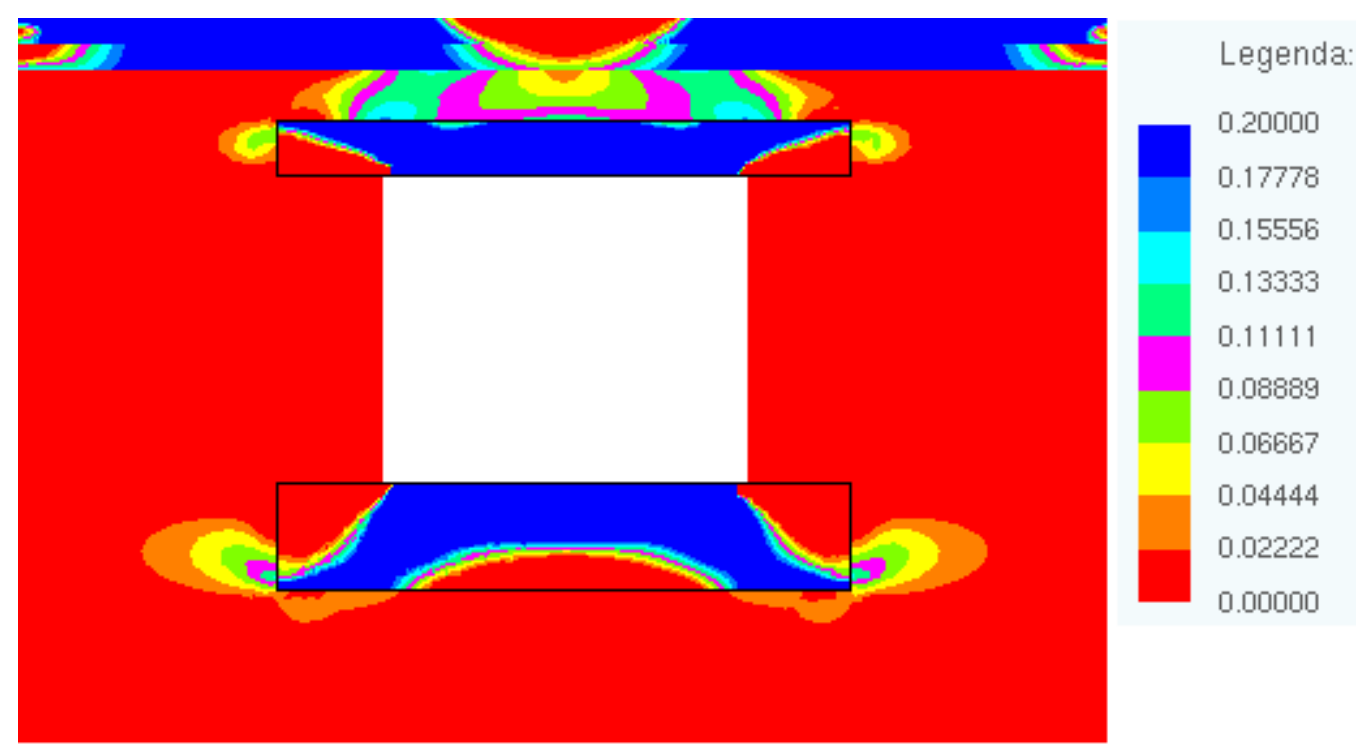

Figura 5.26 - Tensões principais I em painel de parede com abertura de janela com verga de $20 \mathrm{~cm}$ de altura e contraverga com $40 \mathrm{~cm}$ de altura, com valores entre $0 \mathrm{e}$ $0.20 \mathrm{MPa}$.

\subsubsection{JANELA COM VERGA DE 20 CM DE ALTURA E CINTA À MEIA ALTURA COM 40 CM DE ALTURA}

- Tensões principais I, com limite de 0 a $0.25 \mathrm{MPa}$ : 
De acordo com os dados obtidos no painel da Figura 5.25, optou-se por analisar um modelo com as mesmas configurações alterando apenas a altura da cinta, seguindo os mesmos parâmetros das modificações realizadas na Figura 5.26.

Conforme a Figura 5.27 pode-se notar que a verga e a cinta à meia altura da parede com altura equivalente a dois blocos absorvem praticamente toda a tensão de tração, sendo transmitida apenas uma parcela mínima e inferior aos limites permitidos à parede em alvenaria.

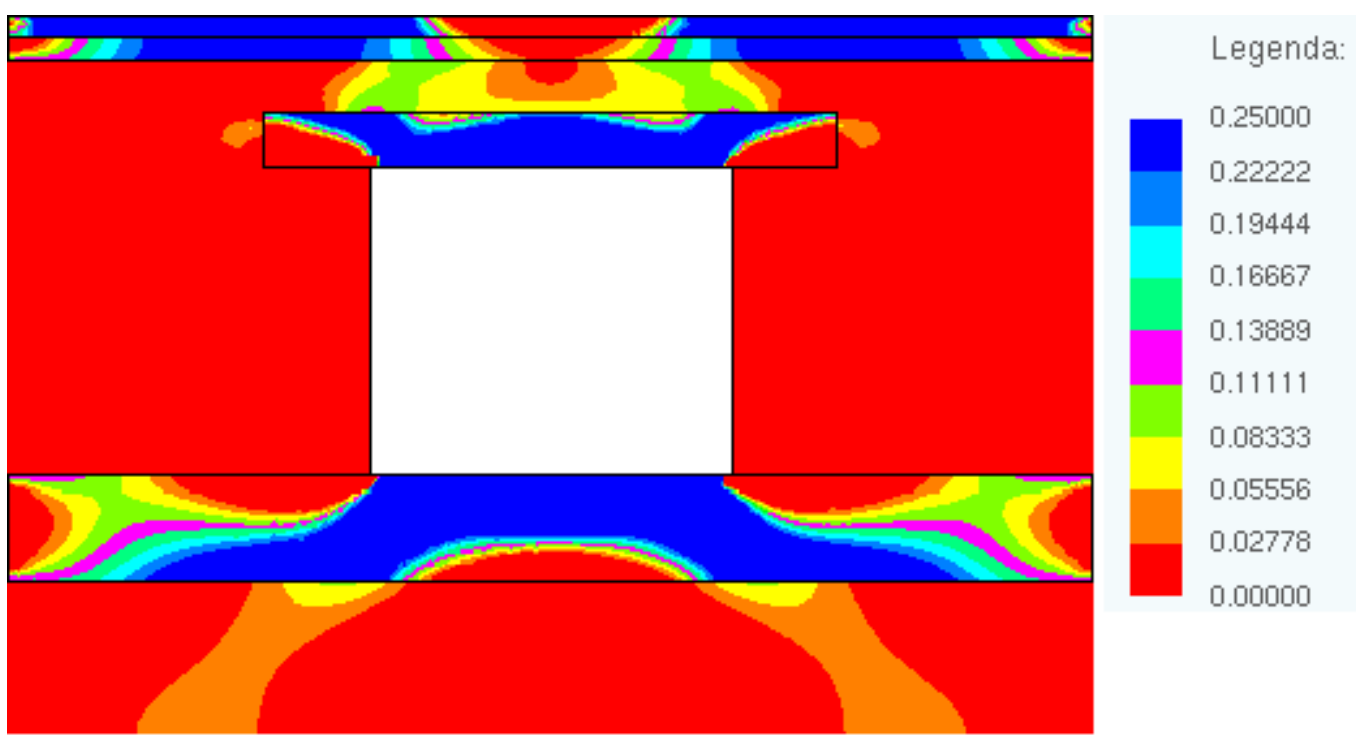

Figura 5.27 - Tensões principais I em painel de parede com abertura de janela com verga de $20 \mathrm{~cm}$ de altura e cinta à meia altura com $40 \mathrm{~cm}$ de altura,com valores entre $0 \mathrm{e}$ $0.25 \mathrm{MPa}$. 


\section{CONCLUSÕES}

Essa pesquisa teve por objetivo analisar as principais fissuras encontradas em edifícios residenciais em alvenaria estrutural, que são as manifestações patológicas de maior ocorrência nesse tipo de estrutura, visando identificar as causas prováveis de seu aparecimento e sugerir possíveis soluções.

Para isso foi realizado um trabalho de campo em edifícios residenciais em alvenaria estrutural em utilização a mais de cinco anos na cidade de São Carlos/SP, onde foram identificados alguns tipos comuns de fissuras. Essas fissuras foram registradas através de fotos para uma posterior comparação entre as fissuras de maior ocorrência nos edifícios analisados.

A partir desse levantamento, verificou-se o aparecimento de diversos tipos de fissuras, tais como:

× Fissuras presentes no contorno dos vãos de portas e janelas;

× Fissuras horizontais no encontro de laje com parede;

× Fissuras mapeadas;

× Fissuras horizontais, que surgem na base da alvenaria;

× Fissuras horizontais à meia altura;

No entanto, fissuras presentes no contorno dos vãos de portas e janelas foram as mais comuns, e estavam presentes em todos os edifícios analisados. Diante disso, optouse por realizar um estudo teórico de paredes com aberturas de portas e janelas visando determinar suas prováveis causas.

Esse estudo foi realizado com um modelo que representava numericamente a geometria, as propriedades e os parâmetros da estrutura. Algumas variáveis, tais como a inserção de verga, contraverga, cinta à meia altura da parede e reforços laterais foram colocadas visando identificar a influência delas em cada um dos modelos. 
Com os resultados obtidos pôde-se observar que a parede em alvenaria estrutural simples sem abertura não apresenta tensões de tração, o que já era esperado.

Nos painéis com aberturas de portas e janelas, verifica-se o aparecimento de tensões de tração sobre e sob as aberturas, resultantes do desvio de tensões gerados pela colocação das aberturas. Essas tensões de tração alcançam valores considerados altos quando comparados com os limites permitidos pela Norma 10837/1989. Nas aberturas de portas sem reforços esses valores chegam a $0.30 \mathrm{MPa}$ e nas aberturas de janelas sem reforços isso ainda é pior, alcançando valores de até $0.60 \mathrm{MPa}$, sendo que os limites permitidos pela Norma citada anteriormente varia entre 0.10 e $0.15 \mathrm{MPa}$.

Dessa forma, essas regiões acima e abaixo de abertura de vãos são locais muito favoráveis ao aparecimento de fissuras provenientes de tensões de tração e por isso devem ser reforçadas.

A partir dos painéis com abertura e sem reforços foram feitas algumas modificações. Na primeira delas foram acrescentadas vergas na parede com aberturas de portas e na parede com abertura de janelas.

Na parede com abertura de porta observou-se que a tensão de tração que antes se concentrava apenas na parte superior da abertura se deslocou para as laterais da verga, sendo que os valores transmitidos à alvenaria são bem menores, visto que a maior parte é absorvida pela verga.

$\mathrm{Na}$ alvenaria disposta na parte superior da verga o valor da tensão de tração é inferior a 0.10MPa. Nas laterais da verga esse valor chega a $0.20 \mathrm{MPa}$ ultrapassando assim o limite de 0.15MPa. Apesar disso, considerando que esse valor ultrapassa pouco o limite e visto que a Norma é usualmente conservadora em seus limites, essa tração pode ser considerada aceitável.

$\mathrm{Na}$ parede com abertura de janela com verga observa-se um comportamento praticamente igual ao ocorrido na parede com abertura de porta com verga na região superior da abertura, sendo que nesse caso a tensão transmitida para alvenaria existente nas laterais da verga não ultrapassou o limite permitido.

Acrescentando-se a contraverga na parede com abertura de janela com verga notase uma redução grande na tensão de tração para a parede em alvenaria na parte inferior da abertura, visto que a contraverga absorve grande parte dela. No entanto, observa-se o 
aparecimento de duas regiões na parte inferir da contraverga com tensões de tração que chegam a $0.18 \mathrm{MPa}$.

Mesmo não apresentando tensões de tração nas laterais das aberturas, optou-se por construir modelos com reforços laterais, que as vezes são utilizados na prática. No caso de paredes com aberturas de portas com vergas e reforços laterais, observa-se o aparecimento de tensões de tração nas laterais do reforço na parte superior da abertura, chegando a $0.14 \mathrm{MPa}$ em alguns pontos na região externa desses reforços. $\mathrm{Na}$ região lateral da abertura não foi verificada nenhuma modificação, o que implica dizer que a utilização do reforço não modifica a configuração das tensões nessa região, onde anteriormente essas tensões também eram nulas.

No caso de paredes com aberturas de janelas com verga e contraverga foram acrescentados dois tipos de reforços, curtos e longos. Nos dois casos as tensões de tração se apresentaram da mesma forma, surgindo pontos de concentração de tensão de tração entre os encontros internos dos reforços com a verga assim como dos reforços com a contraverga, sendo que no caso dos reforços curtos os valores dessas tensões chegaram a $0.60 \mathrm{MPa}$ e no caso dos reforços longos esses valores diminuíram, mas ainda assim ultrapassaram o limite permitido, chegando a $0.33 \mathrm{MPa}$.

Outro modelo analisado foi o de parede com abertura de janela com verga e uma cinta á meia altura da parede em substituição à contraverga. Nesse caso os resultados foram muito parecidos com os da parede com abertura de janela com verga e contraverga, para o qual houve o aparecimento de dois pontos de concentração de tensão de tração na parte inferior da cinta à meia altura, chegando a $0.22 \mathrm{MPa}$.

Diante desses resultados, verificou-se a necessidade da inserção de reforços em paredes com aberturas devido à concentração de tensões que surgem nas partes superior e/ou inferior das mesmas.

É importante salientar que a inserção de verga no caso de paredes com aberturas de portas é o suficiente para a redução da transmissão da tensão de tração para a alvenaria estrutural, visto que não ocorre concentração de tensão de tração significativa nas laterais dos vãos e, além disso, a colocação desse reforço promove o aumento dessa concentração nos encontros entre a verga e os reforços. 
No entanto, verifica-se que com a inserção de reforços laterais, a transmissão de tensões de tração para a parede em alvenaria estrutural diminui de forma a não alcançar os limites permitidos pela norma.

Verificando a diferença dos valores de tensões de tração transmitidos a parede em alvenaria estrutural dos dois modelos citados acima, considerando-se que a Norma se utiliza de meios que a torna muito a favor da segurança e levando em consideração os custos que a inserção do reforço lateral acarretaria o modelo de parede com abertura de porta com verga pode ser considerada o ideal para a utilização em obras.

No caso de paredes com aberturas de janelas, existe ainda a necessidade da inserção da contraverga para a absorção de tensão de tração na parte inferior da abertura.

Diferente do que ocorreu em paredes com aberturas de portas, a inserção de reforços laterais curtos ou longos aumentou a transmissão de tensões de tração para a alvenaria, sendo assim a utilização do reforço não é necessária.

Sendo assim, em casos de paredes com aberturas de janelas é necessária e suficiente a colocação de verga e contraverga.

De acordo com os modelos analisados, verificou-se que diante dos limites apresentados pela Norma 10837/1989, o esquema ideal de parede com aberturas de janelas é o constituído de verga e contraverga com altura de $20 \mathrm{~cm}$.

Isso ocorre, pois a transmissão de tensão de tração à alvenaria dada por este modelo está próxima aos limites permitidos e comparando o aumento do custo devido o aumento da contraverga com a redução pouco significativa dessa transmissão de tração, esse novo modelo não se torna viável.

Da mesma forma, em paredes externas, onde se costuma utilizar cinta à meia altura da parede devido à grande variação de temperatura, o modelo ideal é o modelo constituído por verga e cinta à meia altura da parede com altura de $20 \mathrm{~cm}$.

É importante salientar que os modelos utilizados neste trabalho, conseguem se aproximar dos motivos pelos quais as fissuras provenientes da abertura de vãos de portas e janelas ocorrem, no entanto não podem encontrar as possíveis causas dos demais tipos de fissuras encontradas durante o trabalho de campo. Dessa forma, sugere-se que trabalhos posteriores se utilizem de outros modelos, com parâmetros mais específicos, 
Capítulo 06 - Conclusões

outras variáveis, tais como ação do vento e contraventamento que possam representar melhor numericamente sejam utilizados para essa finalidade. 


\section{REFERÊNCIAS BIBLIOGRÁFICAS}

ASSOCIAÇÃO BRASILEIRA DE NORMAS TÉCNICAS. NBR 6136: Bloco vazado de concreto simples para alvenaria estrutural. Rio de Janeiro, 2006.

ASSOCIAÇÃO BRASILEIRA DE NORMAS TÉCNICAS. NBR 10837: Cálculo de alvenaria estrutural de blocos vazados de concreto. Rio de Janeiro, 1989.

\section{BAUER, Roberto José Falcão. Caderno Técnico Alvenaria Estrutural}

BASSO, Admir. RAMALHO, Marcio Antonio. Corrêa, Márcio Roberto Silva. Fissuras em paredes de alvenaria estrutural sob lajes de cobertura de edifícios. CONPAT/1997.

CAMACHO, Jefferson Sidney. Projeto de edifícios de alvenaria estrutural. Núcleo de Ensino e Pesquisa da Alvenaria Estrutural. Ilha Solteira/SP. 2006

CANO, Rafael Mattos. Patologia em alvenaria estrutural. Trabalho de conclusão de curso. Universidade Anhembi Morumbi. São Paulo. 2005.

CAMPOS, Maurício Dias. Considerações sobre situações para recuperação de prédios construídos com alvenaria resistente. 2006. Dissertação (Mestrado) - Universidade Federal de Pernambuco.

DARINI, Celso Henrique. Proposta de metodologia para aplicação de revestimentos cerâmicos em fachadas de edificações de alvenaria estrutural de blocos de concreto. 2006. Dissertação( Mestrado) - Instituto de Pesquisas Tecnológicas do Estado de São Paulo.

FREITAS, Alexandre Alves de. Análise numérica e experimental do comportamento de prismas e miniparedes submetidos à compressão. 2008. Tese ( Doutorado) - Escola de Engenharia de São Carlos, Universidade de São Paulo, São Carlos.

HOLANDA Júnior, Oswaldo Gomes de. Influência de recalques em edifícios de alvenaria estrutural. 2002. Tese ( Doutorado) - Escola de Engenharia de São Carlos, Universidade de São Paulo, São Carlos.

NASCIMENTO Neto, Joel Araújo do. Estudo de painéis com abertura constituídos por alvenaria estrutural de blocos. 2003. Tese ( Doutorado) Escola de Engenharia de São Carlos, Universidade de São Paulo, São Carlos.

OLIVEIRA, Fabiana Lopes de. Reabilitação de paredes de alvenaria pela aplicação de revestimentos resistentes de argamassa armada. 2001. Tese (Doutorado) - Escola de Engenharia de São Carlos, Universidade de São Paulo, São

Carlos. 
PACCOLA, Rodrigo Ribeiro. Análise não linear física de placas e cascas anisotrópicas laminadas acopladas ou não com meio contínuo tridimensional viscoelástico através da combinação entre o MEC e o MEF. 2004. Tese (Doutorado) - Escola de Engenharia de São Carlos, Universidade de São Paulo, São Carlos.

RAMALHO, Márcio A.; CORRÊA Márcio R.S. Projeto de Edifícios de Alvenaria Estrutural. São Paulo. Editora Pini. 2003.

RICHTER, Cristiano. Qualidade da alvenaria estrutural em habitações de baixa renda: uma análise da confiabilidade e da conformidade. 2007. Dissertação ( Mestrado). Universidade Federal do Rio Grande do Sul.

RIPPER, Thomaz. Patologia, Recuperação e Reforço de Estruturas de Concreto. São Paulo. Editora Pini.

ROMAN, Humberto. Manual de alvenaria estrutural com blocos cerâmicos.

SANTOS, Rodrigo Roderico de Bivar Diogo Pereira. 2004. Análise numérica e experimental do comportamento da alvenaria estrutural submetida á compressão diagonal. Dissertação (Mestrado). Universidade Federal de Santa Maria.

THOMAZ, Ércio. Trincas, em Edifícios: Causas, Prevenção, e Recuperação. São Paulo. Editora PINI. 2001. 